RPP-RPT-54915, Rev. 0

\title{
Hanford Single-Shell Tank Leak Causes and Locations - 241-U Farm
}

\author{
C.L. Girardot, D.G. Harlow
}

Washington River Protection Solutions

Richland, WA 99352

U.S. Department of Energy Contract DE-AC27-08RV14800

$\begin{array}{llll}\text { EDT/ECN: } & \text { DRF } & \text { UC: N/A } & \\ \text { Cost Center: } & \text { 2KE00 } & \text { Charge Code: } 201334 \\ \text { B\&R Code: } & \text { N/A } & \text { Total Pages: } 132 \text { JDA 12/2/13 }\end{array}$

Key Words: leak location, leak cause, tank, integrity assessment, U Farm, U-104, U-110, U-112, leak assessment

Abstract: This document identifies 241-U Tank Farm (U Farm) leak causes and locations for the 100 series leaking tanks (241-U-104, 241-U-110, and 241-U-112) identified in RPP-RPT-50097, Rev. 0, Hanford 241-U Farm Leak Inventory Assessment Report. This document satisfies the U Farm portion of the target (T04) in the Hanford Federal Facility Agreement and Consent Order milestone M-045-91F.

TRADEMARK DISCLAIMER. Reference herein to any specific commercial product, process, or service by trade name, trademark, manufacturer, or otherwise, does not necessarily constitute or imply its endorsement, recommendation, or favoring by the United States Government or any agency thereof or its contractors or subcontractors.

APPROVED

By Janis D. Aardal at 10:59 am, Dec 02, 2013

Release Approval
Date

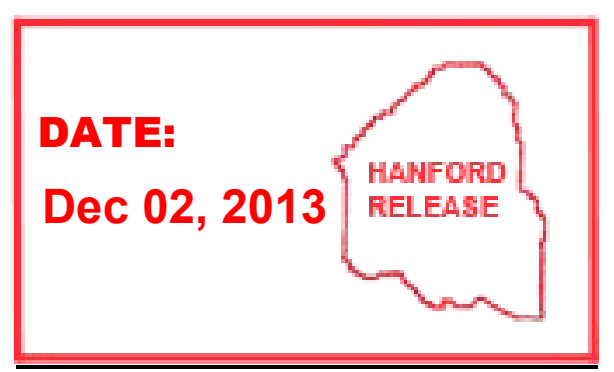

Release Stamp

\section{Approved For Public Release}




\section{EXECUTIVE SUMMARY}

This document identifies 241-U Tank Farm (U Farm) leak causes and locations for the 100-series leaking tanks in U Farm. The leak causes and locations report for all of the 100-series singleshell leaking tanks is one of the targets, M-045-91-T04 (T04), in the Hanford Federal Facility Agreement and Consent Order milestone M-045-91F. The T04 target requires that the DOE provide to State of Washington, Department of Ecology (Ecology) a report on the 100-series single-shell tanks which have been or will be identified as having leaked in RPP-32681, Rev. 0 (Rev. 1), Process to Assess Tank Farm Leaks in Support of Retrieval and Closure Planning, leak assessment reports.

The leak assessment report for U Farm, RPP-RPT-50097, Rev. 0, Hanford 241-U Farm Leak Inventory Assessment Report, identified three 100-series leaking tanks in U Farm, 241-U-104 (U104), 241-U-110 (U-110), and 241-U-112 (U-112). All of the other nine 100-series tanks in U Farm are classified as "sound" or are identified in RPP-RPT-50097 as requiring re-assessment of their classification per TFC-ENG-CHEM-D-42, Tank Leak Assessment Process. The TFC-ENGCHEM-D-42 assessments are not part of the M-045-91-T04 target.

This U Farm leak causes and locations document is part of a series of tank farm reports that identify leak causes and locations for 100-series leaking tanks. A summary and conclusions document will be issued, RPP-RPT-54909, Hanford Single-Shell Tank Leak Causes and Locations - Summary, that compiles the results from all of the leak causes and locations tank farm reports when they have been issued which will fulfill the T04 target requirements.

The identification of U Farm tank leak locations focused on the possible vertical indication of a liner leak from liquid level decreases, radial transport in the soil indicated by radiation detected in drywells, and other factors such as liner bulging. All three leaking U Farm tanks experienced leaking liners at or near the base of the tanks. The tank U-104 five foot bottom liner bulge and the depth of radioactivity detected in tank U-104, U-110, and tank U-112 drywells all point to a liner leak near the bottom of the tank.

Tank U-104 experienced a five foot bulge in the bottom liner which was detected while completing sluicing of the second batch of metal waste (MW). The liner bulge was probably the result of temperature rate of rise especially during the second filling of the tank with MW. This could have set up a situation where vapor pressure under the bottom liner was greater than the hydrostatic pressure. The bulge probably weakened the bottom liner to the point of failure which was confirmed by subsequent leak testing and drywell radioactivity.

Both tank U-110 and U-112 experienced liner failures that were detected by a liquid level decrease and subsequently confirmed by the detection of drywell radioactivity in one of the drywells surrounding each of the tanks. Corrosion may have been a factor in each case as both tank U-110 and U-112 stored REDOX waste which is conducive to pitting and stress corrosion cracking (SCC). Tank U-110 also stored several hundred thousand gallons of unknown laboratory waste which may have influenced corrosion. Tank U-112 may have experienced deformation of the bottom liner during construction which may have resulted in stressing and weakening of the plates and welds. 


\section{RPP-RPT-54915, Rev. 0}

There appears to be very little contribution from tank design and construction temperatures. However, some or all of the factors can act serially or together to contribute to tank failure.

Basic information on the leaking and sound U Farm tanks was reviewed to try and identify any differences between leaking and sound tanks related to liner failure. A number of the sound tanks contained REDOX waste which was thought to have caused the corrosion that resulted in the tank U-110 and tank U-112 liner leaks. However, some other unknown factor influencing corrosion rate or other condition may have prevented a liner leak in the sound tanks. 


\section{TABLE OF CONTENTS}

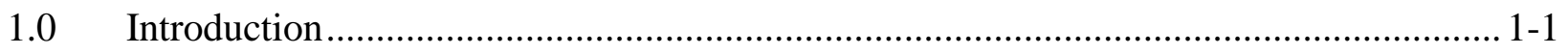

2.0 U Farm Background...................................................................................... 2-1

3.0 U Farm Commonalities .......................................................................... $3-1$

3.1 Tank Design/Construction ...................................................................... $3-1$

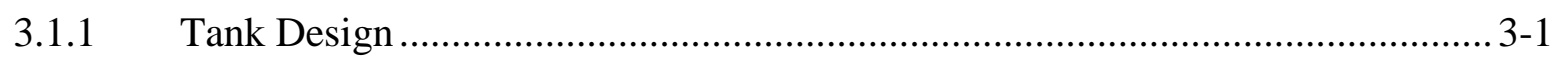

3.1.2 Tank Construction Conditions .................................................................. $3-2$

In-Tank Data For Leaking U Farm Tanks........................................................ 3-3

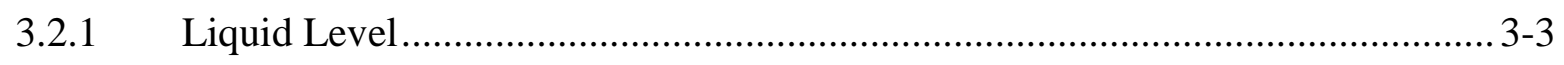

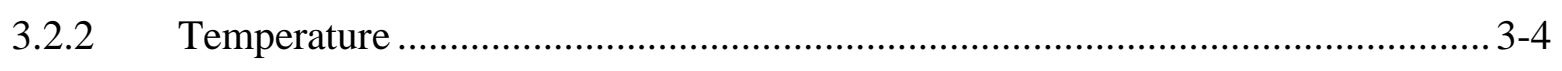

3.2.3 Liner Observations ....................................................................... $3-5$

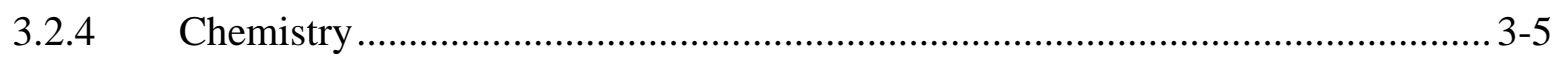

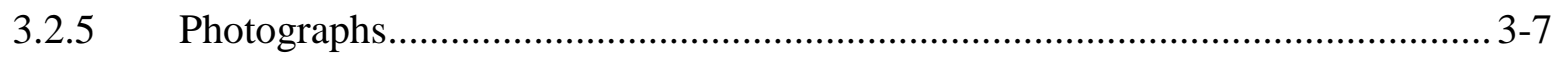

3.3 Ex-Tank Data For Leaking U Farm Tanks ........................................................ 3-8

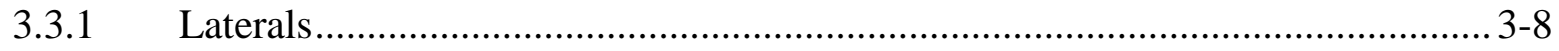

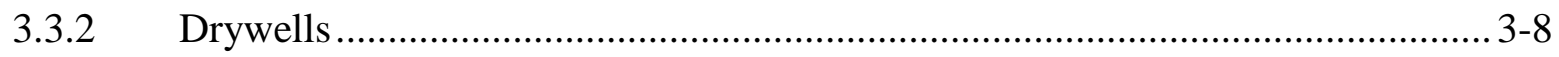

Liner Leak Locations .................................................................................. 3

Possible Liner Leak Cause(s) .................................................................... 3-10

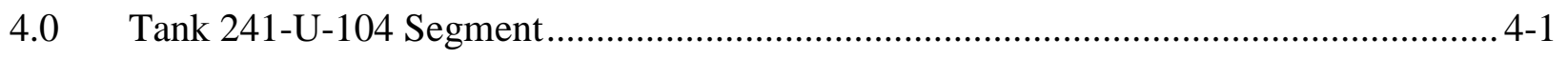

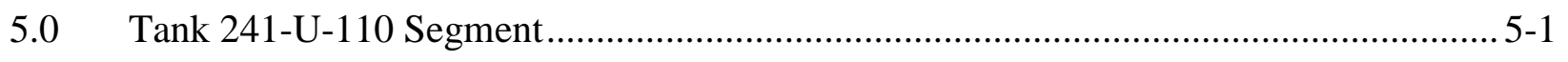

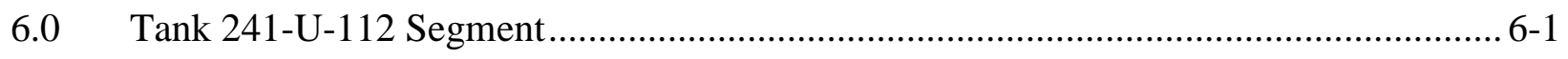

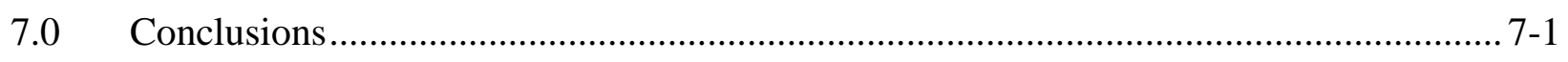

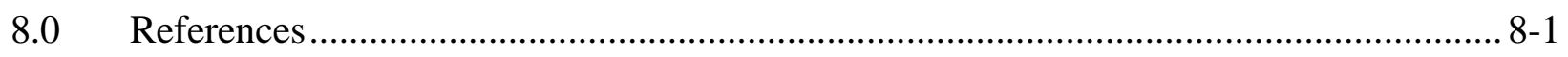

\section{Appendices}

Appendix A Meeting Minutes ................................................................................ A-1 


\section{RPP-RPT-54915, Rev. 0}

\section{LIST OF FIGURES}

Figure 2-1. U Farm and Associated Drywells $2-2$

Figure 3-1. B C T U Tank Farm Knuckle Configuration with Three Ply Waterproofing (BPF-73550, Sheet B5)

Figure 3-2. U Farm Construction Photograph June 24, 1944 (P3496 N1585573)

\section{LIST OF TABLES}

Table 2-1. Leaking U Farm Tanks with Waste Type...................................................... 2-3

Table 3-1. ARH-1601 Specifications 1973 ....................................................................... 3-7

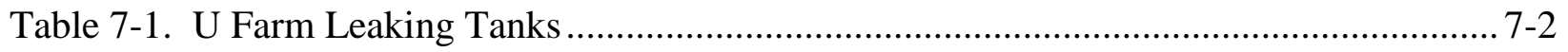

Table 7-2. U Farm Sound Tanks ................................................................................ $7-2$ 
RPP-RPT-54915, Rev. 0

\section{Acronyms and Abbreviations}

\begin{tabular}{|c|c|}
\hline 221-B & B Plant \\
\hline $221-\mathrm{T}$ & T Plant \\
\hline 241-U & U Farm \\
\hline ALC & air lift circulator \\
\hline BGS & below grade surface \\
\hline $\mathrm{BiPO}_{4}$ & bismuth phosphate \\
\hline cpm & counts per minute \\
\hline $\mathrm{c} / \mathrm{s}, \mathrm{cps}$ & counts per second \\
\hline $\mathrm{DE}$ & diatomaceous earth \\
\hline $\operatorname{DST}(\mathrm{s})$ & double-shell tank(s) \\
\hline ECOLOGY & State of Washington, Department of Ecology \\
\hline ENRAF & Pg 3-7 \\
\hline FIC & Food Instrument Corporation \\
\hline GM & Geiger-Mueller probe \\
\hline LL & liquid level \\
\hline MT & manual tape \\
\hline $\mathrm{NaI}$ & sodium-iodide \\
\hline $\mathrm{NO}_{2}^{-}$ & nitrite \\
\hline $\mathrm{NO}_{3}^{-}$ & nitrate \\
\hline OCP & open circuit potential \\
\hline $\mathrm{OH}^{-}$ & hydroxide \\
\hline ORP & Office of River Protection \\
\hline PCSACS & PC Surveillance Analysis Computer System \\
\hline QI & questionable integrity \\
\hline REDOX & Reduction Oxidation Plant \\
\hline $\mathrm{SCC}$ & stress corrosion cracking \\
\hline SGLS & Spectral Gamma Logging System \\
\hline SP & scintillation probe \\
\hline SST(s) & single-shell tank(s) \\
\hline WRPS & Washington River Protection Solutions, LLC \\
\hline
\end{tabular}

\section{Units}

$\begin{array}{ll}{ }^{\circ} \mathrm{C} & \text { degrees Centigrade } \\ \mathrm{Ci} & \text { curie } \\ { }^{\circ} \mathrm{F} & \text { degrees Fahrenheit } \\ \mathrm{ft} & \text { feet } \\ \mathrm{gal} & \text { gallon } \\ \mathrm{K} & 1000 \\ \mathrm{kgal} & \text { kilogallon }\left(10^{3} \text { gallons }\right) \\ \mathrm{in} & \text { inches } \\ \mathrm{M} & \text { moles per liter } \\ \mathrm{mm} & \text { millimeter } \\ \mathrm{mR} / \mathrm{hr} & \text { milliRoentgen Per Hour } \\ \mathrm{pCi} & \text { picocurie }\left(10^{-12} \text { curies }\right)\end{array}$




$\begin{array}{ll}\mathrm{pCi} / \mathrm{g} & \text { picocurie per gram } \\ \mathrm{ppm} & \text { parts per million } \\ \mathrm{yr} & \text { year }\end{array}$

\section{Waste Type Abbreviations}

1C first cycle decontamination waste (form fuels reprocessing plant)

CPLX complexed waste

CW coating waste

DW decontamination waste

EB Evaporator Bottoms

Evap Evaporator feed (post 1976)

HLW high-level waste

LW 222-S Laboratory waste

MW Metal waste

NCPLX non-complexed waste

PNF partial neutralization feed

R REDOX HLW

Resid Residual evaporator liquor

TBP Tri-butyl phosphate waste 


\subsection{INTRODUCTION}

The Hanford Federal Facility Agreement and Consent Order target M-045-91F-T04 indicated that part of the RPP-32681, Process to Assess Tank Farm Leaks in Support of Retrieval and Closure Planning, reporting would include leak causes and locations reports for all of the 100series single-shell leaking tanks. This document is part of a series of documents that identifies leak causes and locations of 100-series single-shell leaking tanks that have been identified in the individual RPP-32681 tank farm leak assessments. An overall leak causes and locations summary and conclusions document will be prepared along with background and common tank farm information when all of the 100-series single-shell leaking tanks have been addressed (RPP-RPT-54909, Hanford Single-Shell Tank Leak Causes and Locations - Summary and Conclusion, to be issued). The information from RPP-RPT-54909 will be incorporated into the summary conclusions report on leak integrity for the Hanford Federal Facility Agreement and Consent Order milestone M-045-91F.

The 241-U Tank Farm (U Farm) tanks with a leak loss are addressed in this document. The U Farm assessment in RPP-RPT-50097, Rev. 0, Hanford 241-U Farm Leak Inventory Assessment Report, reported a leak loss for tanks 241-U-104 (U-104), 241-U-110 (U-110), and 241-U-112 (U-112) and recommended that tank 241-U-101 (U-101) be further assessed using TFC-ENGCHEM-D-42, Tank Leak Assessment Process. The TFC-ENG-CHEM-D-42 assessments are not part of the M-045-91-T04 target.

The identification of U Farm tank leak locations focused on the first indication of radiation detected in drywells as well as liquid level decreases as appropriate. Leak detection laterals were not installed underneath the U Farm tanks.

The U Farm leak causes were identified as chemistry-corrosion and in the case of tank U-104, thermal conditions which likely resulted in the liner bulging upward. There appears to be very little contribution from tank design and construction temperatures. However, some or all of the factors can act serially or together to contribute to tank failure.

Three meetings were held to review status of tanks U-104, U-110, and U-112 with the Office of River Protection (ORP) and the State of Washington, Department of Ecology (Ecology) personnel. A review on June 25, 2013, covered the information that had been generated on the location of the tank U-104 leak and supporting data. A second meeting on August 6, 2013, provided a review of the tank U-110 leak causes and locations document. A third meeting on September 10, 2013, provided a review of the tank U-112 leak causes and locations document along with a comparison of the available information on the other U Farm tanks. Comments were received, responses developed, and additions/revisions were made to the document (see Appendix A). 


\subsection{U FARM BACKGROUND}

The U Farm was constructed between 1943 and 1944 and is located west of Camden Avenue and north of $14^{\text {th }}$ Street in the 200 West Area. The farm includes twelve 100-series dish bottom design SSTs. The tanks are 75-ft in diameter with an operating capacity of 530,000 gallons (WHC-SD-WM-ER-325, Rev. 1, Supporting Document for the Historical Tank Content Estimate for U-Tank Farm). A typical 100 series tank in U Farm contains 10 to 12 risers ranging in size from 4-in to 42-in in diameter that provide grade-level access to the underground tank.

Normally, there is one riser in the center of the tank dome and four or five each on opposite sides of the dome. The tanks are arranged in four rows of three tanks forming a cascade. The cascade overflow height is $\sim 15.9-\mathrm{ft}$ from the tank knuckle bottom and 2.0 - $\mathrm{ft}$ below the top of the steel liner.

Figure 2-1 shows a schematic of the U Farm tanks with location of the drywells. 
Figure 2-1. U Farm 100-Series Tanks and Associated Drywells (RPP-35485, Rev. 0)

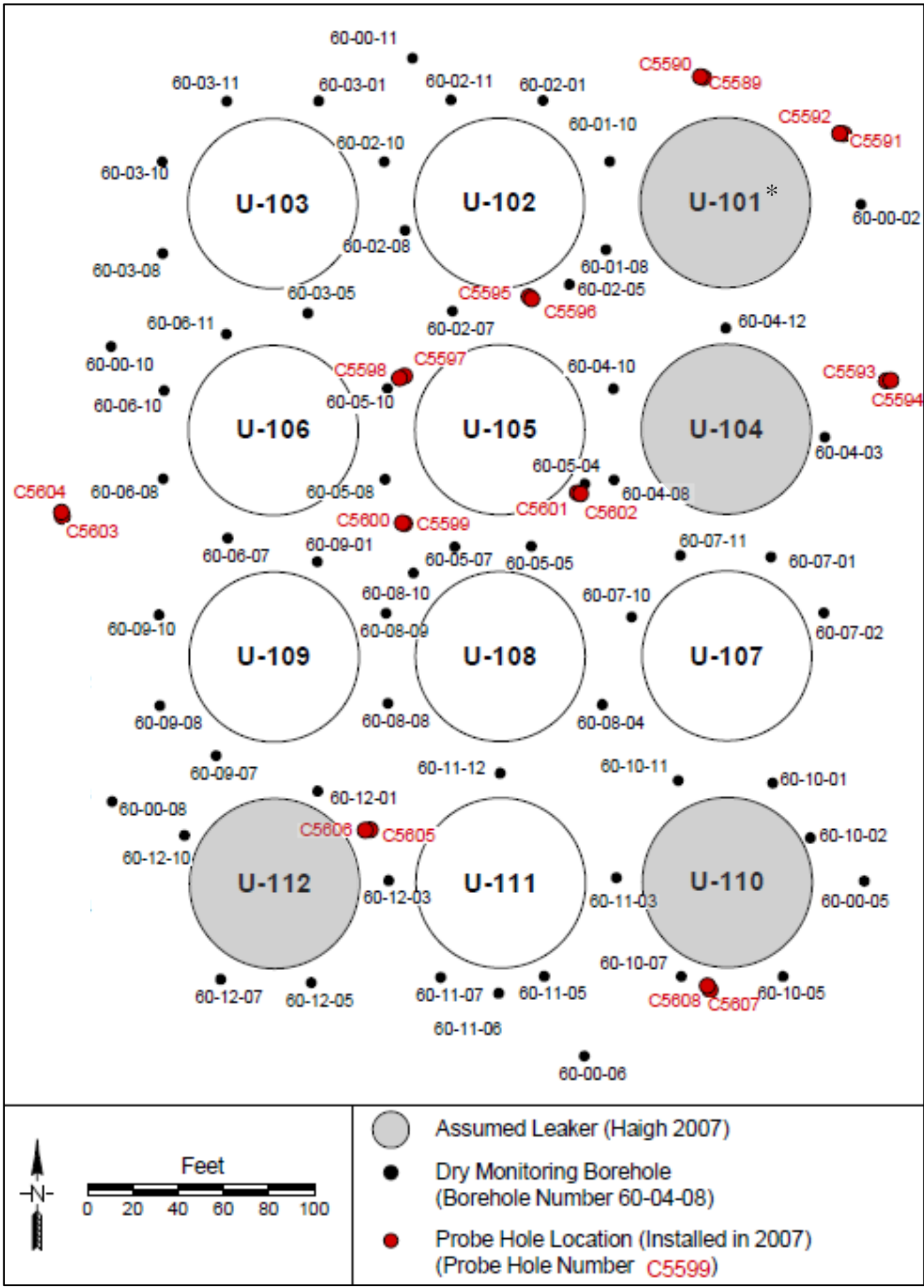

* Tank U-101 was recommended to be assessed using the TFC-ENG-CHEM-D-42 procedure as identified in RPP- RPT-50097. Therefore, tank U-101 was not evaluated in this document. 
Tanks U-104, U-110, and U-112 contained various waste types throughout operation which are listed in Table 2-1. The following sections describe some of the important common tank features and conditions that could affect tank leak causes and locations. This is followed by the individual tank analyses of the possible leak locations and causes and a comparison of leaking and non-leaking tanks in the conclusion section. The sections contain excerpts from RPP-RPT50097, Rev. 0 .

Table 2-1. Leaking U Farm Tanks with Waste Type

\begin{tabular}{|c|c|}
\hline Tank & Waste Type $^{1}$ \\
\hline $\mathrm{U}-104$ & $\mathrm{MW}$, water \\
\hline $\mathrm{U}-110$ & $1 \mathrm{C}, \mathrm{CW}, \mathrm{R}, \mathrm{LW}$ \\
\hline $\mathrm{U}-112$ & $1 \mathrm{C}, \mathrm{CW}, \mathrm{R}$ \\
\hline \multicolumn{2}{|l|}{ Note: Waste types are listed in the List of Terms } \\
\hline
\end{tabular}




\subsection{U FARM COMMONALITIES}

\subsection{TANK DESIGN/CONSTRUCTION}

\subsubsection{Tank Design}

The U Farm SSTs are constructed of 1-ft thick reinforced concrete with a 0.25 -in thick mild carbon steel liner (ASTM A7-39) on the bottom and sides with knuckle plates 0.3125-in thick and a 1.25-ft thick domed concrete top. The tanks have a dished bottom with a 4 -ft radius knuckle.

The tanks are set on a reinforced concrete foundation. A three-ply waterproofing was applied over the foundation and then coated with a 2-in thick layer of grout reinforced with wire mesh. A three-ply waterproof membrane was applied directly to the outside of the steel surface up the sidewalls. Four coats of primer paint were sprayed on all exposed interior tank surfaces. Tank ceiling domes were covered with three applications of magnesium zincfluorosilicate wash. Lead flashing was used to protect the joint where the steel liner meets the concrete dome. Asbestos gaskets were used to seal the access holes in the tank dome. Each tank was covered with $\sim 5.6$ to 7.2-ft of overburden.

The tanks have four process spare inlet nozzles located $\sim 16.5$-ft from the tank knuckle bottom, $\sim 0.6$-ft above the cascade overflow line and 1.4-ft below the top of the steel liner. The steel bottom of the U Farm tanks intersects the sidewall on a 4-ft radius (BPF-73550, Drawings D-2 and D-3, Specification for Construction of Composite Storage Tanks (B, C, T, and U Tank Farms)).

Figure 3-1 shows the detail of the knuckle liner to the grout, and three-ply asphaltic waterproof membranes between the bottom and sidewall intersection (BPF-73550, Sheet D5).

\section{Figure 3-1. B C T U Tank Farm Knuckle Configuration with Three-Ply Waterproofing} (BPF-73550, Sheet D5)

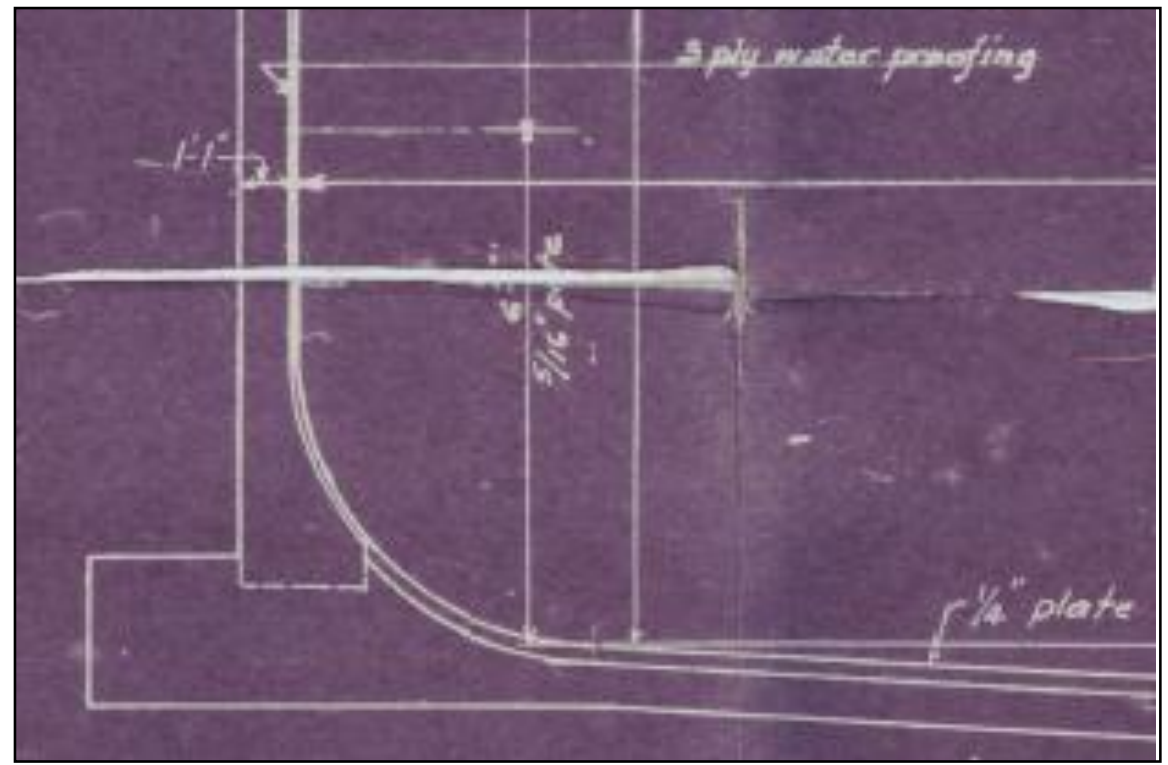




\subsubsection{Tank Construction Conditions}

The U Farm construction temperatures were examined to determine if the tank liner fabrication occurred at or below the metal ductile-to-brittle temperature transition. The photograph in Figure 3-2 shows the U Farm under construction on June 24, 1944.

Figure 3-2. U Farm Construction Photograph June 24, 1944 (P3496 N1585573)

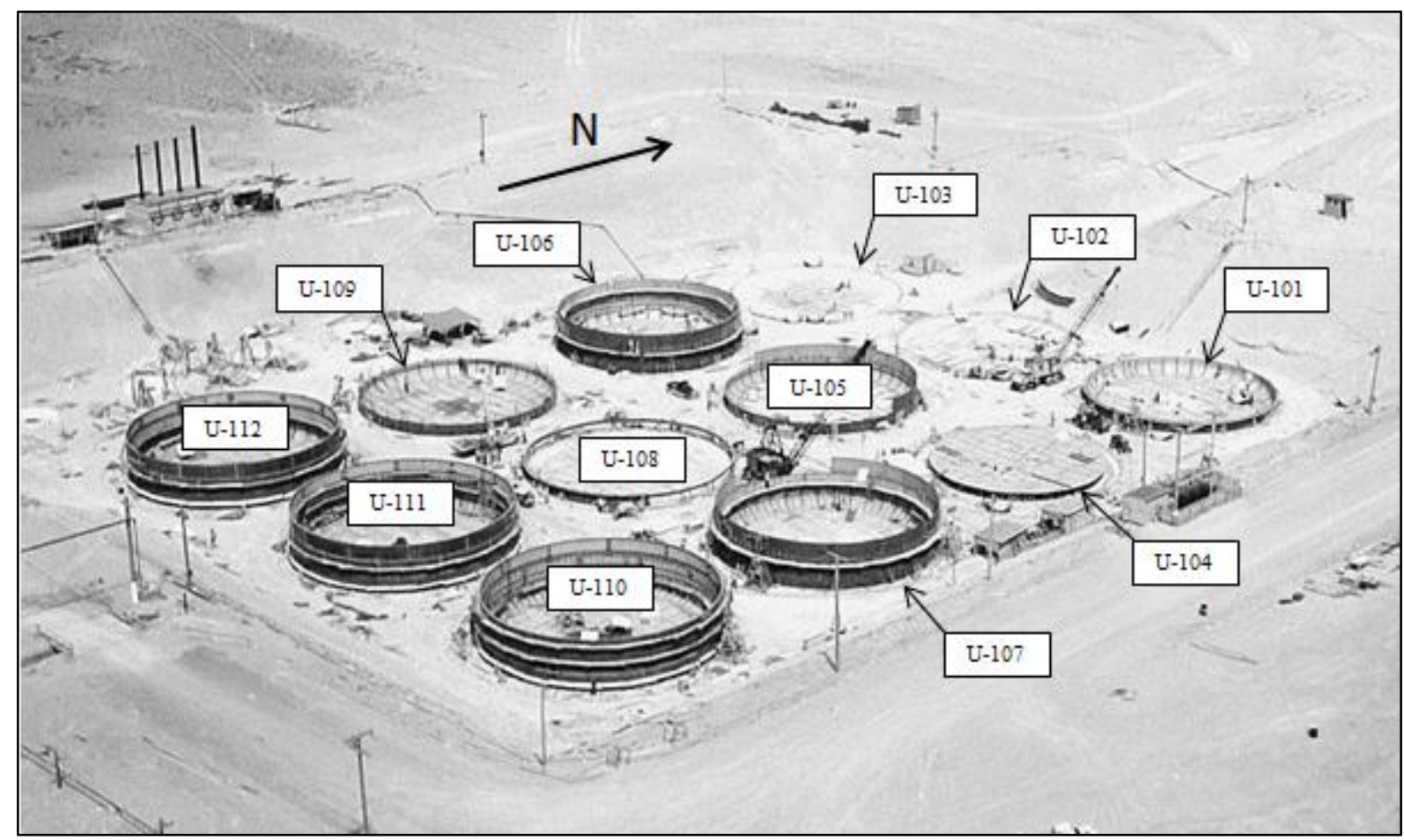

The metallurgical factors that limited carbon steel's ability to resist impact at low temperature were perhaps not well understood when U Farm was constructed and were not specified for the 0.25-in thick ASTM A7-39, American Society for Testing and Materials, Standard Specifications for Steel for Bridges and Buildings, mild carbon steel liner at the time. Current standards for construction of pressure vessels, ASME Boiler \& Pressure Vessel Code (B\&PVC), Section VIII, Rules for Construction of Pressure Vessels, provide requirements for vessels constructed of carbon and low alloy steels with respect to minimum design metal temperatures. That standard does not identify ASTM A7-39, as a material type but it does identify ASTM A283, Standard Specification for Low and Intermediate Tensile Strength Carbon Steel Plates. Early versions of ASTM A283 were similar to ASTM A7-39 because they identified the same chemical composition requirements as ASTM A7-39, and ASTM A283 steel plate and ASTM A7-39 steel plate had the same required tensile strength range, minimum yield point, and bending properties. Current B\&PVC Section VIII requirements specify, for ASTM A283 material of nominal thickness $\leq 10-\mathrm{mm}(0.394-\mathrm{in})$, a minimum design metal temperature of $18^{\circ} \mathrm{F}$. For the purposes of this report, it will be assumed that the $18^{\circ} \mathrm{F}$ design temperature is applicable to the fabrication of ASTM A7-39 carbon steel. 
Boxes from the list of Vendor Information Reports for U Farm were searched for any Chemical and Physical Test Reports for the tank steel plates used in the farm but none were found. No other construction information for U Farm was found during the search.

A review of toughness and the ductile-to-brittle transition temperature for carbon steels (designated as "impact transition temperature") in Mark's Standard Handbook for Mechanical Engineers, Tenth Edition, indicates that carbon content can have a significant effect. Decreased carbon content not only raises the propagation energy needed for crack growth but also lowers the temperature for transition from ductile-to-brittle behavior (reference Fig 6.2.11 in Marks), suggesting that the B\&PVC Section VIII low temperature service limit may be lower than what could be expected for steel of the vintage used in U Farm construction. The concentrations of carbon and trace impurities and their effect on this property are not specifically known, and low temperature impact resistance could only be determined reliably by impact testing of actual tank specimens.

Below the transition temperature, the metal loses its ability to absorb forces such as induced loads, or the impact of falling objects without fracturing. In this circumstance it is possible for micro-fissures or hairline cracks to be created. Later, when the metal is subjected to high stress, it might be possible for the cracks to propagate through the metal, or possibly subject the weakened areas to increased corrosion.

Any low temperatures experienced during construction at or less than the $18^{\circ} \mathrm{F}$ allowable temperature where impact loading (e.g. a dropped tool or piece of equipment from scaffolding) had the potential for creating micro-fissures may have triggered fissures in the steel liner (see Sections 4.3.2, 5.3.2, and 6.3.2).

Design, fabrication, and erection of the tank steel lining were required to be in accordance with current "Standards Specifications for Elevated Steel Water Tanks, Standpipes and Reservoirs" as promulgated by the "American Water Works Association" (BPF-73550). Welding and inspection requirements were to conform to the American Welding Society's "Code for Arc and Gas Welding in Building Construction”, Section 4.

The possible variability of liner steel from either different runs from the same supplier, or because of multiple suppliers could affect the resistance to low temperatures.

\subsection{IN-TANK DATA FOR LEAKING U FARM TANKS}

The general information in this section is further developed and applied to the leaking tanks in Sections 4.4, 5.4, and 6.4 for tanks U-104, U-110, and U-112, respectively, to understand implications of the conditions that could affect liner leaks and identify possible liner leak locations.

\subsubsection{Liquid Level}

The following is an excerpt from RPP-ENV-39658 (Hanford SX-Farm Leak Assessments Report): 
"Originally liquid levels were measured using pneumatic dip tubes (HW-10475-C, Hanford Technical Manual Section C, page 908). This practice was later replaced and a manual tape with a conductivity electrode was used to detect the liquid surface (H-2-2257, Conductor Reel for Liquid Level Measurement). The biggest limitations of the manual tape measurements were failures of the electrodes, solids forming on the electrode and measurement precision. The statistical accuracy of the manual tape and electrode measurement technique was 0.75 in. ( 2,060 gal), as determined in July 1955 (HW-51026, Leak Detection - Underground Storage Tanks, page 4). Later, liquid-level determinations were automated in many of the SSTs to provide more accurate and reliable measurements".

It was stated in RPP-RPT-43704 (Hanford BY-Farm Leak Assessments Report) that the accuracy for the manual tape can vary from 0.25 -in to 2 -in for different tanks depending on surface conditions (liquid/solids), boiling, air lift circulator (ALC) operation, and conductivity.

The in-tank repeatability limits for FIC liquid level gauges are \pm 0.25-in (Letter 72730-80-097, "Review of Classification of Six Hanford Single-Shell "Questionable Integrity (QI)" Tanks").

Transfer discrepancies of greater than 1.5-in (4,125 gal) measured at the first hour and every two hours thereafter with an FIC, manual tape, or flowmeter required an orderly and immediate shutdown, investigation, and notification. The 1.5-in discrepancy requirement was a specification limit in ARH-1601, Section D, Specifications and Standards for the Operation of Radioactive Waste Tank Farms and Associated Facilities.

Liquid level measured by manual tape (MT) is calculated for B, C, T, and U Farm tanks with the formula: volume $=($ MT Reading X 2750 gal/in $)+12,500$ gal $($ LET-082172, H.N. Raymond to C.J. Francis, August 21, 1972, Maximum Operating Levels and Cascade Levels in 200-West area Tank Farms [IDMS Accession D196208887]). Even though the letter title indicates only west area, the above formula for the B, C, T, and U Farm tanks is found on the last page of the letter. The formula was confirmed to have been used as late as 1980 in RHO-CD-896, Review of Classification of Nine Hanford Single-Shell "Questionable Integrity" Tanks, page 76, for the then current tank T-111 volume (488,000 gal) and MT reading (173-in) which verified use of the formula. All half yearly and quarterly report ending volumes in this document were calculated with this formula. Original MT readings and the MT readings in PCSACS are all measured from the lower knuckle of the above tanks which is 12-in above the bottom inside center of the tanks. The ENRAF liquid level readings in PCSACS have been converted to read from the bottom inside center of the tank. Therefore, for the same reported liquid level the ENRAF reading is 12in greater than the MT reading.

\subsubsection{Temperature}

Limited temperature data is available for the U Farm tanks until the 1970s. Available waste temperatures starting in the 1970s can be found in WHC-SD-WM-ER-325, Rev. 0, RHO-CD1172, Survey of the Single-Shell Tank Thermal Histories, and in PCSACS. Historical documents in the following two paragraphs can be used to infer probable tank temperatures for the storage of waste in the U Farm tanks (see Sections 4.4.2, 5.4.2, and 6.4.2 for individual tank waste temperature). 
The U Farm tank construction specifications indicated the temperature of the liquid contents would be (up to) $220^{\circ} \mathrm{F}$ (HW-1946, Specifications for Composite Storage Tanks - Buildings \#241 at Hanford Engineering Works). The condensers on the B, C, T, and U Farm tanks 101 through 106 were reported to be adequate for the waste temperatures and vapor loads for the original operations at approximately $180^{\circ} \mathrm{F}$ for supernatant and sludge (WHC-MR-0132, $A$ History of the 200 Area Tank Farms).

The earliest operation limitations found for U Farm are addressed in ARH-951, Limitations for Use of Underground Waste Tanks. The ARH-951 document was issued December 18, 1969 and indicated that tank temperatures for should be held below $230^{\circ} \mathrm{F}$ with a $5^{\circ} \mathrm{F}$ per day rise for liquid temperatures below $180^{\circ} \mathrm{F}$ and a $3^{\circ} \mathrm{F}$ per day rise for liquid temperatures above $180^{\circ} \mathrm{F}$ during waste addition to the tank.

\subsubsection{Liner Observations}

A bulge, typically caused by rapid vaporization of moisture under the tank liner, may result in the direct failure of the liner or cause enough stress or thinning on the steel liner plates and welds that they become more susceptible to the effects of corrosion without producing a permanent bulge. Experience indicates that bulging tends to be a dynamic phenomenon, and it is possible that a tank with no measured bulge at one point in time may actually have had a displaced liner that was not detected at another time.

\subsubsection{Chemistry}

The types of corrosion that may occur in the Hanford Site SSTs include uniform corrosion, stress corrosion cracking (SCC), pitting, crevice, and liquid-air interface corrosion which were identified in PNNL-13571, Expert Panel Recommendations for Hanford Double-Shell Tank Life Extension.

Uniform corrosion rates for SSTs are reported to be generally less than 1 mil/year (HNF-3018, Rev. 0, Single-Shell Tank Sluicing History and Failure Frequency) for the SSTs. Carbon steel exposed to alkaline solutions has a low general corrosion rate (PNL-5488, Prediction Equations for Corrosion Rates of A-537 and A-516 Steels in Double Shell Slurry). However, the presence of the nitrate ion may induce various forms of localized attack (i.e., SCC, pitting, etc.).

\section{Nitrate Ion-Induced Stress Corrosion Cracking}

Stress corrosion cracking is the growth of cracks in a corrosive environment. It can lead to unexpected sudden failure of normally ductile metals subjected to a tensile stress, especially at elevated temperatures. Stress corrosion cracking is highly chemically specific in that certain alloys are likely to undergo SCC only when exposed to a small number of chemical environments. The chemical environment that causes SCC for a given alloy is often one which is only mildly corrosive to the metal otherwise.

Nitrate ion-induced SCC is the predominant threat to the integrity of the steel liners in the SSTs and DSTs at the Hanford Site and many investigations have been performed to establish the parameters under which the tanks can be protected from this threat. This work, together with the 
efforts of many others, led to the adoption of the waste chemistry control limits for SCC prevention in 1983 (OSD-T-151-00017, Operating Specifications for the Aging Waste Operations in Tank Farms 241-AY and 241-AZ).

The factors governing the rates of nitrate ion-induced SCC cracking by Hanford Site DST wastes were recently reviewed (RPP-RPT-47337, Specifications for the Minimization of the Stress Corrosion Cracking Threat in Double-Shell Tank Wastes). In brief, the test results led to the conclusion that the rates of nitrate ion-induced SCC depended on the properties of the steel, the applied potential versus the open circuit potential (OCP), the temperature and the concentrations of aggressive substances such as nitrate ion, and the potential inhibitors such as hydroxide and nitrite ion.

The technical work has shown that SCC is promoted by high temperatures, high nitrate ion concentrations, low hydroxide ion concentrations, low nitrite ion concentrations, and low nitrite ion/nitrate ion concentration ratios. Tanks with maximum temperatures less than $122^{\circ} \mathrm{F}$ would not be expected to experience significant SCC damage regardless of waste types (HNF-3018, Rev. 0). Tanks with the maximum temperatures above $122^{\circ} \mathrm{F}$ and a ratio of nitrate concentration to the sum of nitrite and hydroxide concentrations greater than 2.5 would be expected to suffer SCC-related damage (HNF-3018, Rev. 0). The concentration of nitrate and temperature are parameters that have the most effect on SCC. However, the $\mathrm{pH}$ (hydroxide) and nitrite can inhibit SCC. The current double-shell tank operating specifications for chemistry are reported in OSD-T-151-00007, Rev. 10, Operating Specifications for the Double-Shell Storage Tanks. While the chemistry specifications stated in this document were prepared for the DSTs, corrosion mechanisms and corrosion protection mechanisms applicable to DST primary tank metal liners are equally applicable to the older SST metal liners.

\section{Localized Corrosion: Crevice, Pitting, and Liquid-Air Interface Corrosion}

Crevice corrosion can occur in regions where a small volume of solution cannot readily mix with the bulk solution such as under deposits, between metal flanges, and other confined areas. Once initiated, crevice corrosion proceeds by the same mechanism as pitting corrosion (RPP-RPT33306, IQRPE Integrity Assessment Report for the 242-A Evaporator Tank System).

Pitting corrosion is the localized corrosion of a metal surface confined to a point or small area that takes the form of cavities. Pitting corrosion in dilute solutions $\left(\mathrm{NO}_{3}{ }^{-}<1 \mathrm{M}\right)$ of waste has been studied at the Savannah River Site (SRS). Pitting has been determined to not be a problem at hydroxide concentrations greater than $1 \mathrm{M}$ for any of the diluted waste solutions tested (WSRC-TR-90-512, Effect of Temperature on the Nitrite Requirement to Inhibit Washed Sludge; Oblath and Congdon 1987, Inhibiting Localized Corrosion during Storage of Dilute Waste). Nitrate ion was determined to be the usual controlling aggressive species when its concentrations ranged between $0.01 \mathrm{M}$ and 1M (WSRC-TR-90-512). The presence of hydroxide ion and nitrite ion has shown to inhibit pitting corrosion due to the aggressive nitrate ion. This work led to the conservative recommendation that the concentration of nitrite ion be greater than $0.033 \mathrm{M}$ for the avoidance of pitting in dilute solutions of nitrate ion at $\mathrm{pH} 10$ and $40^{\circ} \mathrm{C}\left(104^{\circ} \mathrm{F}\right)$ (RPP-ASMT-53793, Rev. 0, Tank 241-AY-102 Leak Assessment Report). 
The chemical compositions required for prevention of pitting corrosion can also be applied as limits for prevention of liquid-air interface corrosion at the surface of the supernatant.

Crevice, pitting, and liquid-air interface corrosion are types of localized corrosion possible in the SSTs; however, historically SCC is the more predominant type of corrosion of concern.

\section{Historical Corrosion Control}

The earliest chemical specifications for SSTs addressing $\mathrm{pH}$, nitrite, nitrate, and hydroxide are listed in Table 3-1 (ARH-1601, Section D).

Table 3-1. ARH-1601 Specifications 1973

\begin{tabular}{|c|c|}
\hline \multicolumn{2}{|c|}{ Waste Tank Farms and Associated Facilities Specifications } \\
\hline Variable & Specification \\
\hline $\mathrm{pH}$ & Minimum 8.0 \\
\hline $\mathrm{NO}_{2}^{-}$ & $500 \mathrm{ppm}$ \\
\hline $\mathrm{NO}_{3}^{-}$ & $<6 \mathrm{M}$ \\
\hline $\mathrm{OH}^{-}$ & $<7 \mathrm{M}$ \\
\hline
\end{tabular}

There was no similar specification found that addressed all of these parameters during the operation of U Farm prior to 1973. However, if the ARH-1601 specifications were in effect during prior $\mathrm{U}$ Farm waste storage, the storage of undesirable concentrations of $\mathrm{NO}_{2}{ }^{-}, \mathrm{NO}_{3}{ }^{-}$, and $\mathrm{OH}^{-}$could result in vulnerability to SCC and/or localized corrosion.

Historical waste sample data as well as temperatures are typically not available for the SSTs and none were recovered for tanks U-104, U-110, and U-112. Thus, the concentrations of $\mathrm{NO}_{2}^{-}$, $\mathrm{NO}_{3}{ }^{-}$, and $\mathrm{OH}^{-}$listed in Sections 4.4.4, 5.4.4, and 6.4.4 are typical concentrations that were found in reports and other sources for the waste types listed. The reports may be based on limited data and/or values or were obtained from process flowsheets. Therefore, waste chemistry concentrations may not reflect the actual conditions when specific tank sample and temperature data is unavailable especially when multiple waste types are present in the tank. Individual tank sections provide information on the waste types stored in the tank.

\subsubsection{Photographs}

Available photographs of the U Farm leaking tanks U-104, U-110, and U-112 were reviewed. Photographs were reviewed to identify beachlines possibly indicating previous operations of overfilling the tank, damaged equipment, possible liner bulges, and any other anomalies that could be indicative of a tank liner leak, and/or possible leak location. See Sections 4.4.5, 5.4.5, and 6.4.5 for details for tanks U-104, U-110, and U-112, respectively. The photographs do not indicate a liner bulge for tanks U-110 and U-112. The 5-ft bulge reported in tank U-104 was visible in available photographs. The tank U-112 photographs show a pattern of solids below the liquid surface that appears to follow plate weld lines on the bottom tank liner (see Section 6.4.5). 
RPP-RPT-54915, Rev. 0

\subsection{EX-TANK DATA FOR LEAKING U FARM TANKS}

The general information in this section is further developed and applied to the leaking tanks in Sections 4.5, 5.5, and 6.5 for tanks U-104, U-110, and U-112, respectively, to understand implications of the conditions that could affect liner leaks and identify possible liner leak locations.

\subsubsection{Laterals}

Leak detection laterals were installed approximately $10-\mathrm{ft}$ underneath some of the tanks containing self-boiling waste in 241-A and 241-SX Farms. Each lateral is a 3-in pneumatic stainless steel tubing enclosed in 4-in carbon steel pipe. Probes were driven to the end of the lateral with compressed air then slowly withdrawn to gather a radiation profile below the bottom of the tank. Lateral leak detection systems were not installed under the U Farm tanks.

\subsubsection{Drywells}

Six drywells are located around tanks U-104 and U-112 and seven drywells are located around tank U-110. The earliest tank specific drywells were installed in 1970 through 1976; later four direct pushes were installed in 2007. All of the radiation readings in drywells are assumed to be maximum or peak readings unless otherwise noted. Drywells were drilled vertically from the surface and drywell coordinates and detailed drywell information, e.g., pipe dimensions and configuration, for tanks U-104, U-110, and U-112 are addressed in references cited in the individual tank segments. Drywells will not be useful to detect releases that enter the soil from the tank unless the volume released is sufficiently large to facilitate lateral transport to a drywell typically to within $\sim 1$-ft of the drywell. The vertical height of a tank liner leak may not be directly related to the point of detection in the drywell. This is especially true for small leaks that may flow downward some distance before encountering a drywell.

The "00" series drywells (drywell 60-00-05, U Farm) were installed shortly after tank construction, usually around the periphery of the farm and most extend to $150-\mathrm{ft}$ below grade surface (BGS). Others with tank numbers embedded in the drywell number (60-04-01, tank U104) were constructed later, sometimes after tank operations had ceased and generally to 100-ft BGS, with a few deeper than 100-ft BGS. The usual number of drywells surrounding a tank is one to four. If there are more, then there likely was some concern regarding a release which was being investigated. The last number corresponds to the clocked position of the drywell with respect to due north.

Four gamma ray probe types were used to monitor gamma in drywells to detect leaks (RPP8321, Analysis and Summary Report of Historical Dry Well Gamma Logs for the 241-C Tank Farm 200 East Area). The most widely used probe was the unshielded gross gamma sodiumiodide (NaI) probe (or probe 04 ; the shielded NaI probe was referred to as probe 14). The NaI probe (04) is very sensitive and able to record gamma ray activity from 30 counts per second (cps) up to about 40,000 cps $(15 \mathrm{mR} / \mathrm{hr})$ before the data becomes unreliable (RHO-RE-EV-4P, Supporting Information for the Scientific Basis for Establishing Dry Well Monitoring Frequencies. The next most commonly used probe was the Red-GM (or probe 02) which is less sensitive but can reliably record gross gamma at much higher levels of activity (up to $\sim 500 \mathrm{R} / \mathrm{hr}$ ). 
Operation of these and other probes are discussed in HNF-3136, Analysis Techniques and Monitoring Results, 241-SX Drywell Surveillance Logs. A scintillation probe (SP) was also used to measure low levels of radiation in the drywells. Leak location identification is primarily focused on the first indication of a leak and is therefore typically concerned with the lower levels of gross gamma detection and initial migration.

Drywell sections (see Sections 4.5.1, 5.5.1, and 6.5.1) contain gross gamma figures taken from RPP-7729, Analysis and Summary Report of Historical Drywell Gamma Logs for 241-U Tank Farm-200 West, showing continuing or new contamination in the drywells based on BGS depth from 1975 to 1994. Some of these gross gamma figures show anomalous data that appear to be unexplained detections that do not reflect radioactivity in the soil. In 1996, a baseline characterization of the gamma-ray-emitting radionuclides distributed in the vadose zone sediments beneath and around U Farm was performed using spectral gamma logs (SGLS) and documented in GJO-HAN-8, Vadose Zone Characterization Project at the Hanford Tank Farms $U$ Tank Farm Report. Individual vadose zone characterization summary data reports were issued in 1996 for the U Farm tanks with results reported in the leaking tank segments. The gross gamma and the SGLS can detect equivalent Cs-137 at concentrations down to $10 \mathrm{pCi} / \mathrm{g}$ and $\sim 0.1 \mathrm{pCi} / \mathrm{g}$ respectively. Therefore, radioactivity $\leq 10 \mathrm{pCi} / \mathrm{g}$ does not appear on the gross gamma figures (GJO-HAN-8). SGLS logging can confirm both Cs-137 and/or Co-60 radioactivity which can assist in the leak location analysis, and the SGLS data is weighted more heavily on interpreting drywells. SGLS documents refer to processed U-235/U-238 which refers to irradiated isotopic distribution versus naturally occurring uranium found in the soil. The criteria for drywell monitoring are defined in RHO-ST-34, A Scientific Basis for Establishing DrywellMonitoring Frequencies, with the monitoring frequency found in SD-WM-TI-356, Waste Storage Tank Status and Leak Detection Criteria.

All of the radiation readings in drywells are assumed to be maximum or peak readings unless otherwise noted and are from the Red-GM probe unless otherwise indicated. The individual tank segments report the available drywell data in the drywell section and in some cases the more recent direct pushes installed to locate detailed soil radioactivity. The drywell summary section provides the analyses of the associated drywells and any direct pushes with the tank that is of concern.

\subsection{LINER LEAK LOCATIONS}

Drywell radioactivity when first detected can indicate a radial or depth location of a tank leak, migration of the tank leak, or the possible migration of an adjacent tank leak. The radial drywell radioactivity is also dependent on any possible flow paths from the actual tank liner leak location to the drywell itself as well as the waste viscosity and distance to the drywell. Drywells can also indicate the tank liner sidewall leak vertical location but the indication needs to be analyzed relative to non-tank liner leaks associated with pipe lines or other sources.

Liquid level decreases can be used for sidewall as well as bottom liner leaks but need to be analyzed in relationship with the vertical level of the tank drywell radioactivity, evaporation, and drywell contamination from pipe line leaks and other non-tank sources. 
A liner leak may have penetrated the waterproof membrane at any location and followed concrete cracks or construction joints to a different location including the top of the tank footing. Therefore, the point of waste egress from the tank liner may not be the point of entry of the leaking waste to the soil. Later indications of radioactivity in the drywells with improved detector capabilities could indicate additional leakage but the location of the leak could not be pinpointed without some additional information.

The lack of radioactivity above background in a drywell indicates that if there was a liner leak it either occurred at another location, the leak flow was insufficient to reach the effective radius of the probes used in the drywell, or was not able to adequately detect the specific radioisotope with the gamma probe. When there is no radioactivity detected in a drywell or no recoverable data for a drywell it is not included as part of the leak location analysis.

\subsection{POSSIBLE LINER LEAK CAUSE(S)}

Analysis of the U Farm commonalities which centered on tank design/construction, in-tank data, and ex-tank data indicates that there was essentially one condition, chemistry-corrosion, that was the most likely to have contributed to a possible tank failed liner for tanks U-110 and U-112. In the case of tank U-104, waste thermal conditions likely resulted in the reported liner bulge. There appears to be very little contribution from tank design (no inherent flaws have been documented in the literature reviewed), construction temperatures, and waste thermal conditions. However, some or all of the factors can act serially or together to contribute to tank liner failure. The following sections provide a tank U-101, U-110, and U-112 review of these conditions as they relate to liner leak causes.

Other general tank construction factors such as the quality of materials and fabrication could also contribute to tank liner failure. Because no evidence has been found to substantiate quality defects, these are not included as a leak cause. 


\subsection{TANK 241-U-104 SEGMENT}

\section{TABLE OF CONTENTS}

4.1 Tank U-104 Background History ..................................................................... 4-4

4.2 Tank U-104 Operations Summary …............................................................ 4-5

4.3 Tank Design/Construction ........................................................................ $4-8$

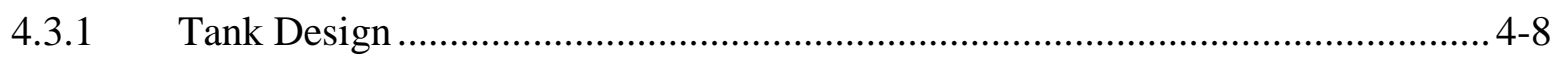

4.3.2 Tank Construction Conditions ................................................................. 4-8

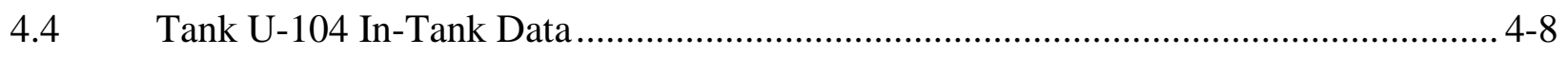

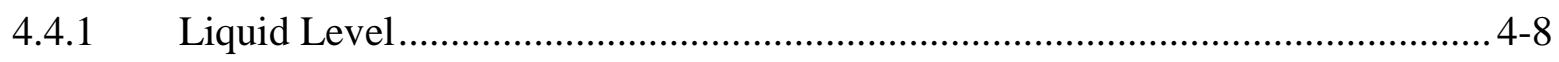

Temperature .................................................................................... 4-10

4.4.3 Liner Observations ............................................................................... 4-11

4.4.4 Chemistry-Corrosion............................................................................ 4-13

4.4.5 Photographs.................................................................................... 4-13

4.5 Tank U-104 Ex-Tank Data............................................................................. 4-13

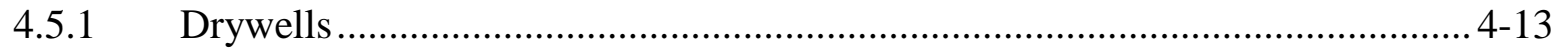

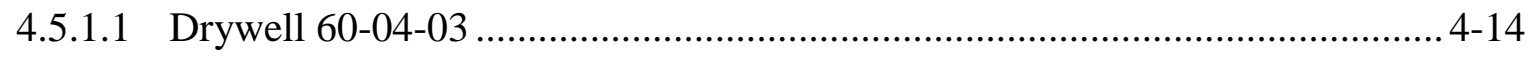

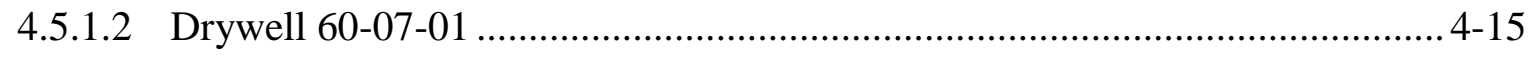

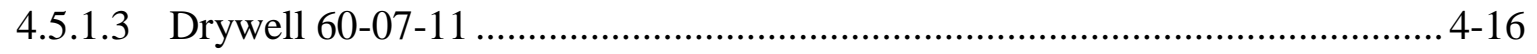

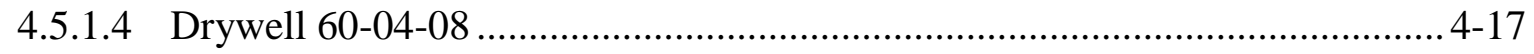

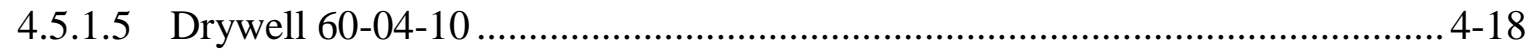

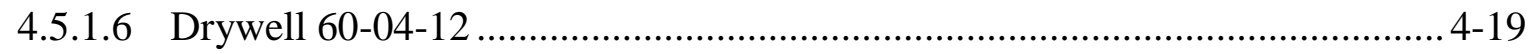

4.5.1.7 2007 Direct Pushes............................................................................ 4-20

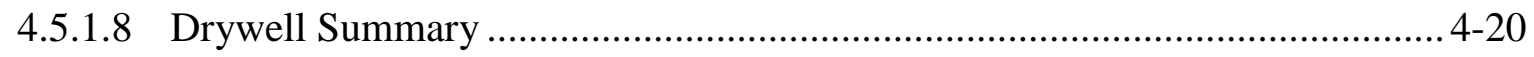

4.6 Possible Tank U-104 Liner Leak Location(s) ..................................................... 4-20

4.6.1 Leak Detected in 1974-1976 ............................................................. 4-21

4.6.2 Leak Detected in 2007 ...................................................................... 4-23

4.6.3 Leak Location Summary ....................................................................... 4-24

4.7 Possible Tank U-104 Liner Leak Cause(s) ..................................................... 4-26

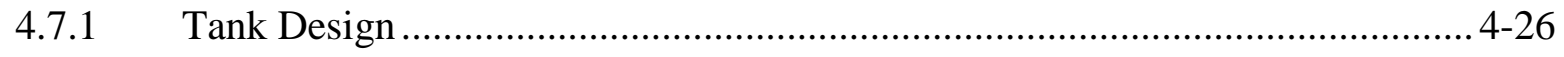

4.7.2 Thermal Conditions .............................................................................. 4-26 


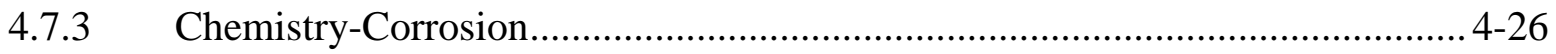

4.7.4 Liner Observations ........................................................................... 4-26

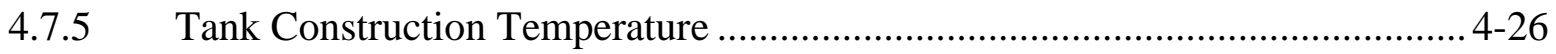

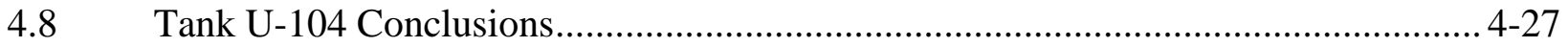

\section{Appendices}

Appendix A1 Tank U-104 Non-Boiling Waste Operational History ....................................... A1-1

Appendix B1 Tank U-104 Gross Gamma Drywell Data ..................................................... B1-1

\section{LIST OF FIGURES}

Figure 4-1. Tank U-104 Associated Drywells ...................................................................... 4-4

Figure 4-2. Operational Leak History of Tank U-104 ….................................................... 4-7

Figure 4-3. Tank U-104 End of Quarter Surface Level .......................................................... 4-9

Figure 4-4. Tank U-104 Liquid Level April 1957 through March 1961 .................................. 4-10

Figure 4-5. Tank U-104 Bulged Bottom Liner August 15, 1956............................................. 4-12

Figure 4-6. Tank U-104 Drywell 60-04-03 (RPP-7729) …………………………….......... 4-14

Figure 4-7. Tank U-104 Drywell 60-07-01 (RPP-7729) ……………………………........... 4-15

Figure 4-8. Tank U-104 Drywell 60-07-11 (RPP-7729) ......................................................... 4-16

Figure 4-9. Tank U-104 Drywell 60-04-08 (RPP-7729) ………………………................. 4-17

Figure 4-10. Tank U-104 Drywell 60-04-10 (RPP-7729) ....................................................... 4-18

Figure 4-11. Tank U-104 Drywell 60-04-12 (RPP-7729) …………………………………. 4-19

Figure 4-12. Tank U-104 Possible Leak Location (1974-1976) ............................................... 4-22

Figure 4-13. Tank U-104 Possible Leak Location (2007) ..................................................... 4-23

Figure 4-14. Tank U-104 Possible Radial Leak Locations ..................................................... 4-25 


\section{RPP-RPT-54915, Rev. 0}

\section{LIST OF TABLES}

Table 4-1. Tank U-104 Waste Storage Chronology ........................................................... 4-13

Table 4-2. Waste Chemistries for Waste Types Stored in Tank U-104................................ 4-13

Table A1-1. ARH-R-43 Waste Tank Leak Experience Table ............................................ A1-2

Table B1-1. Tank U-104 Drywell Radioactivity (K counts per minute) (April 1974 through November 1986) ....................................................................... B1-2 


\subsection{TANK U-104 BACKGROUND HISTORY}

This section provides information on the historical waste loss event associated with Single-Shell Tank (SST) 241-U-104 (U-104). There are six drywells located around tank U-104 with specified distances from the drywell to the tank footing shown in Figure 4-1: 60-04-03, 60-0711, 60-04-08, 60-04-10, and 60-04-12, installed in 1974, and 60-07-01, installed in 1976. Two nearby direct pushes were installed in 2007.

The bottom of the tank footing is $\sim 38$-ft 4-in Below Grade Surface (BGS) with $\sim 6.5$-ft soil cover over the dome (WHC-SD-WM-TI-665, Soil Load above Hanford Waste Storage Tanks; BPF73550).

Figure 4-1. Tank U-104 Associated Drywells

Tank inner ring is steel liner; outer ring is outer edge of tank footing

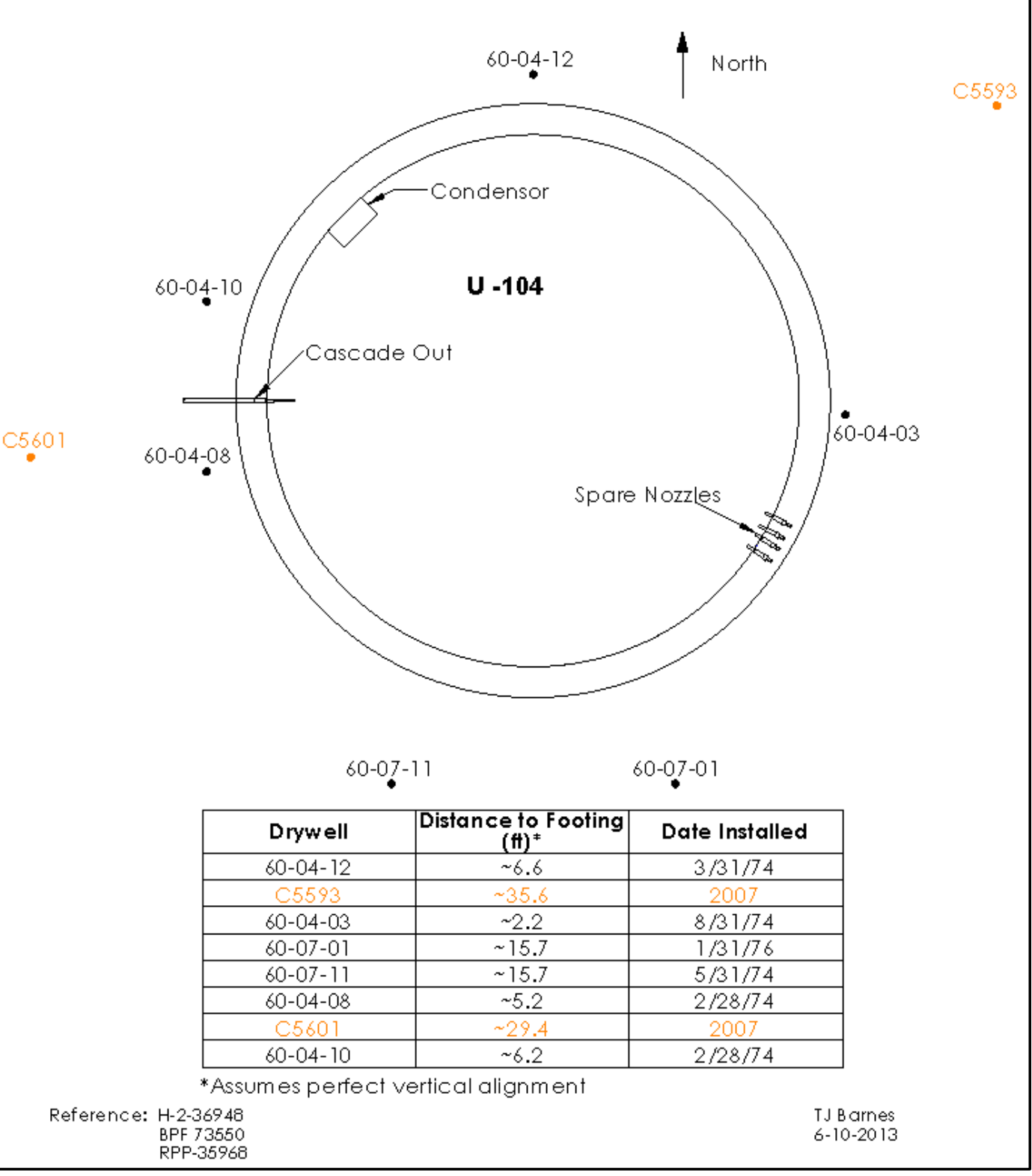


RPP-RPT-54915, Rev. 0

\subsection{TANK U-104 OPERATIONS SUMMARY}

Tank U-104 was placed into service in the third quarter of 1947 and began receiving metal waste (MW) from 221-T Plant (T Plant) in July 1947 (HW-7283-DEL, Hanford Engineer Works Monthly Report July 1947). The tank was declared full by the end of December 1947 and waste began to cascade to tank U-105 (HW-8438-DEL, Hanford Works Monthly Report December 1947). Metal waste cascaded into tank U-105 and tank U-106 through September 1948 when the three tank cascade was full (HW-11226-DEL, Hanford Works Monthly Report September 1948). No transfers occurred until supernatant was pumped to tank U-101 in the fourth quarter of 1952. The MW was sluiced out of the tank beginning in late January 1953 and the tank was empty by June 1953 (SD-WM-TI-302, Hanford Waste Tank Sluicing History).

The tank was refilled with MW from T Plant October 8, 1954 (HW-33544, Separations Section, Waste-Status Summary for October 1954) and the tank was full by the next monthly report (HW33904, Separations Section, Waste-Status Summary for November 1954). The supernatant was pumped out of the tank beginning in January 1956 to prepare for sluicing (Internal memorandum EM-TF-040.9a, "Inspection of Waste Storage Tank 241-U-104"). Sluicing of tank U-104 was initiated on July 5, 1956 (HW-44024-RD, TBP Plant and Tank Farm Weekly Summary - Process Unit-6-29-56 thru 8-31-56). Shortly after, sluicing was discontinued due to a pipe leak in the 151-UR diversion box. Normal sluicing was resumed on July 10, 1956 for tank U-104 but only for a couple days as a leak from tank U-104 was suspected by July 20, 1956. During sluicing operations when it was time to install the heel jet through the pit at the center of the tank, it was discovered that the center of the tank bottom was higher than normal and installation could not be accomplished. Internal memorandum EM-TF-040.9a states, "By means of electrode measurement the tank farm group determined that the center of the tank bottom was approximately five feet higher than normal." The methods of this measurement remain unknown. The tank contained 1,000 gal of sluicing liquid and 1,000 gal of MW sludge at the completion of sluicing (HW-44860, Separations Section, Waste - Status Summary July 1956).

Following this observation, a periscope was installed on July 26, 1956 to try to confirm suspicion of a bulge. The next week, as reported in HW-44024-RD, TBP Plant and Tank Farm Weekly Summary - Process Unit-6-29-56 thru 8-31-56, "a definite bulge in the center of the tank and what appeared to be a meandering split in the steel plates of the bulged portion" was confirmed and on August 15, 1956 photographs were taken inside tank U-104. It was reported in HW44024-RD that these photographs confirmed the bulge (see Section 4.4.3 for additional details). Tank U-104 is the only known non-boiling waste SST that experienced a tank bottom bulge.

Water was added to the tank in April 1957 to test for a leak and the monthly liquid level readings indicate the level was decreasing; however, this water was not removed until March 31, 1961 (DSI 1961, “104-U Tank"). The tank was declared an assumed leaker in 1961. A significant volume of this water remained in the tank due to a bulged bottom which interfered with removal of the liquid heel until it was again pumped in the first quarter of 1965. In the fourth quarter of 1969 waste was added to the tank from an unknown source, increasing the waste volume to 106 kgal with $40 \mathrm{kgal}$ solids. Process records list the tank waste type as R (REDOX) waste. However, it appears this was a mistake as the waste type was changed from MW to R on the process records without any transfers occurring. Therefore, the source of the 1969 transfer remains unknown. 
RPP-RPT-54915, Rev. 0

In May 1972, 60 tons of diatomaceous earth (DE) was added to tank U-104 to absorb any remaining free liquids (ARH-CD-222, Characterization of the Effects of Diatomaceous Earth Additions to Hanford Wastes).

Tank U-104 was declared administratively interim stabilized in October 1978. As of February 28, 2013, tank U-104 contains $54 \mathrm{kgal}$ of sludge (HNF-EP-0182). The estimated volume is equivalent to approximately 31.6 -in referenced to the tank center bottom.

The operational history of tank U-104 leak related details including liquid level is charted in Figure 4-2. 


\section{Figure 4-2. Operational Leak History of Tank U-104}

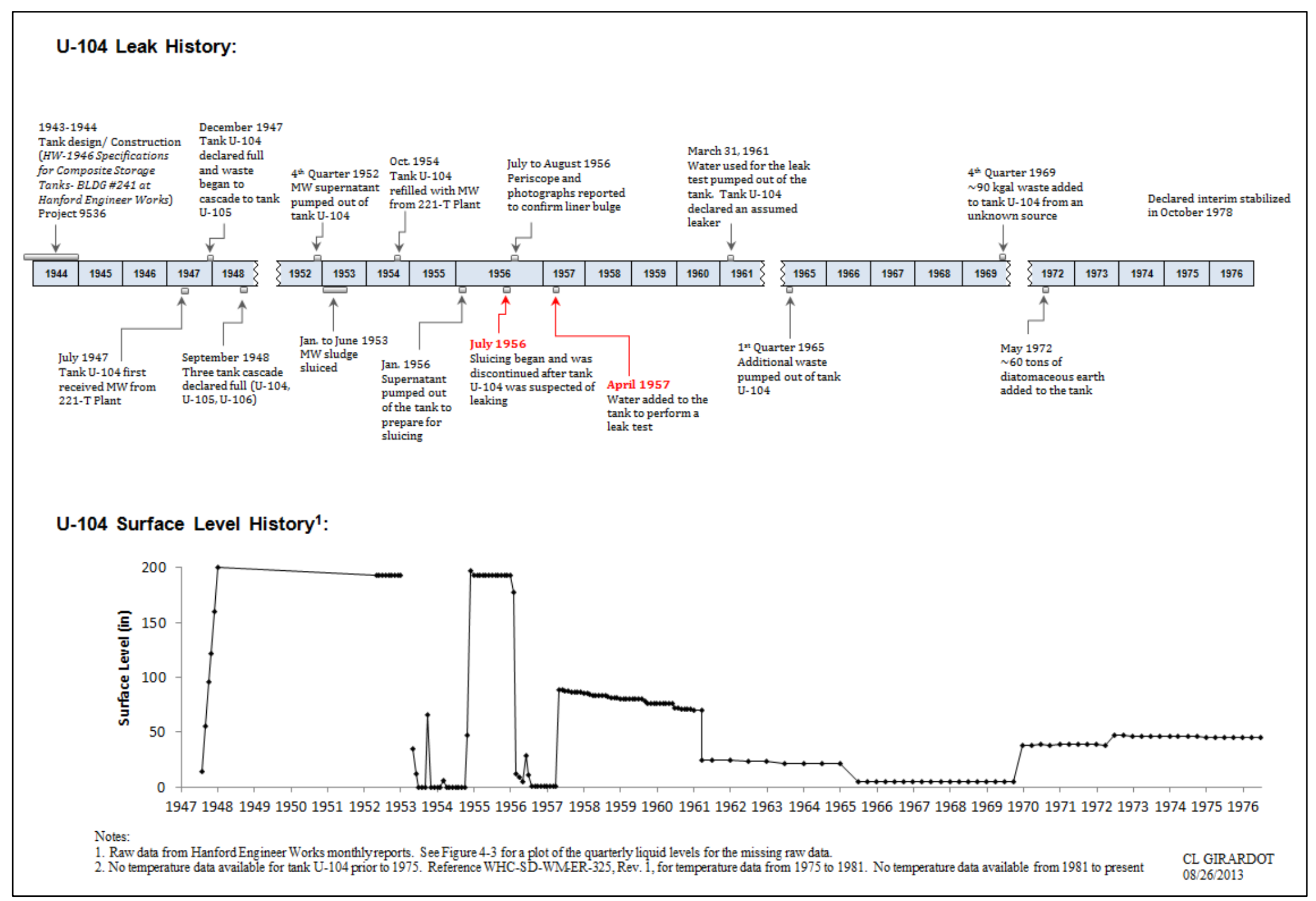


RPP-RPT-54915, Rev. 0

\subsection{TANK DESIGN/CONSTRUCTION}

\subsubsection{Tank Design}

The steel bottoms of the U Farm tanks intersect the sidewall on a 4-ft radius knuckle transition (BPF-73550, Drawings D-2 and D-3). The rounded knuckle transition, the three-ply asphaltic membrane waterproofing between the liner and the concrete, a notched footing construction joint, and the concrete shell are features common to all U Farm tanks (see Section 3.1.1).

\subsubsection{Tank Construction Conditions}

The U Farm tanks were constructed between February 1944 and October 1944. Temperatures are not available for 1944 between May 18 and December 1. From the start of U Farm tank construction through May 18, 1944 there were two minimum temperatures of $12^{\circ} \mathrm{F}$ with daytime temperatures of $44^{\circ} \mathrm{F}$ and $57^{\circ} \mathrm{F}$, one at $18^{\circ} \mathrm{F}$, and four at $20^{\circ} \mathrm{F}$ with day time temperatures between $41^{\circ} \mathrm{F}$ and $56^{\circ} \mathrm{F}$.

As described in Section 3.1.2, cold weather affects the ductile-to-brittle steel transition temperature, with $18^{\circ} \mathrm{F}$ being the assumed design temperature for the carbon steel liner, which could result in a fracture upon impact. However, in general, the temperatures during the U Farm construction time frame were much milder than those experienced during 241-SX Farm construction where ductile-to-brittle steel transition temperatures were exceeded.

Design, fabrication, and erection of the tank steel lining were required to be in accordance with current "Standard Specifications for Elevated Steel Water Tanks, Standpipes and Reservoirs" as promulgated by the "American Water Works Association" (BPF 73550). Welding requirements were required to conform to the American Welding Society's "Code for Arc and Gas Welding in Building Construction", Section 4.

\subsection{TANK U-104 IN-TANK DATA}

\subsubsection{Liquid Level}

The liquid level plot in Figure 4-3 indicates the transfer activity into and out of tank U-104. The liquid levels are end of quarter levels so this figure may not reflect all transfers into and out of

the tank that occurred during the operational history. See Figure 4-2 for historical monthly liquid level readings. 


\section{Figure 4-3. Tank U-104 End of Quarter Surface Level}

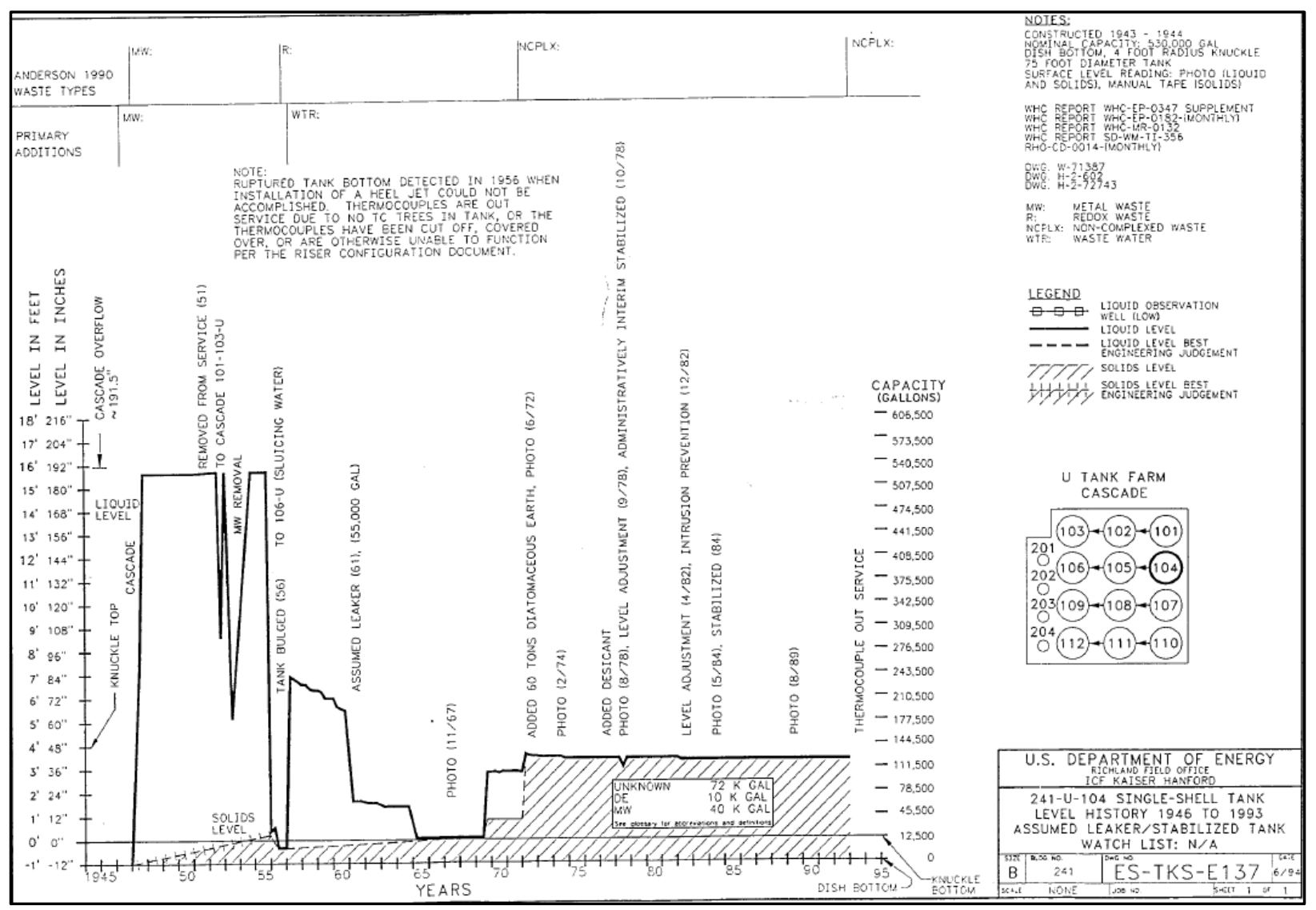

WHC-SD-WM-ER-325, Rev. 0, 1994, Supporting Document for the SW Quadrant Historical Tank Content Estimate for U-Tank Farm.

Tank U-104 was first suspected of leaking during sluicing operations of the MW sludge in July 1956 (HW-44024-RD). During this time there were no reports indicating an unknown decrease in the liquid level; however, a tank liner bulge was suspected. In-tank photographs and a periscope confirmed a liner bulge in tank U-104 (see Section 4.4.3).

In April 1957, approximately $242 \mathrm{kgal}$ of water was added to the tank (on top of the $2 \mathrm{kgal}$ of waste) to perform a leak test. The liquid level decreased from $244 \mathrm{kgal}$ reported at the end of April 1957 to $194 \mathrm{kgal}$ reported on March 23, 1961 (DSI 1961) a potential loss of $50 \mathrm{kgal}$ at a leak rate of approximately $35 \mathrm{gal} /$ day over the four year span. No recorded liquid level decrease observations were recovered between the report of the liner bulge in July 1956 and the addition of the water for a leak test in April 1957. It remains unknown why the leak test lasted for a period of about four years and why the tank contents were not pumped out as the liquid level was decreasing. However, there are several periods where the liquid level remained unchanged for several months as shown in Figure 4-4. Tank U-104 was the first tank suspected of leaking and the first suspected of having a bulged liner (ARH-R-43, Rev. 2, Management of Radioactive Wastes Stored in Underground Tanks at Hanford). 
RPP-RPT-54915, Rev. 0

Figure 4-4. Tank U-104 Liquid Level April 1957 through March 1961

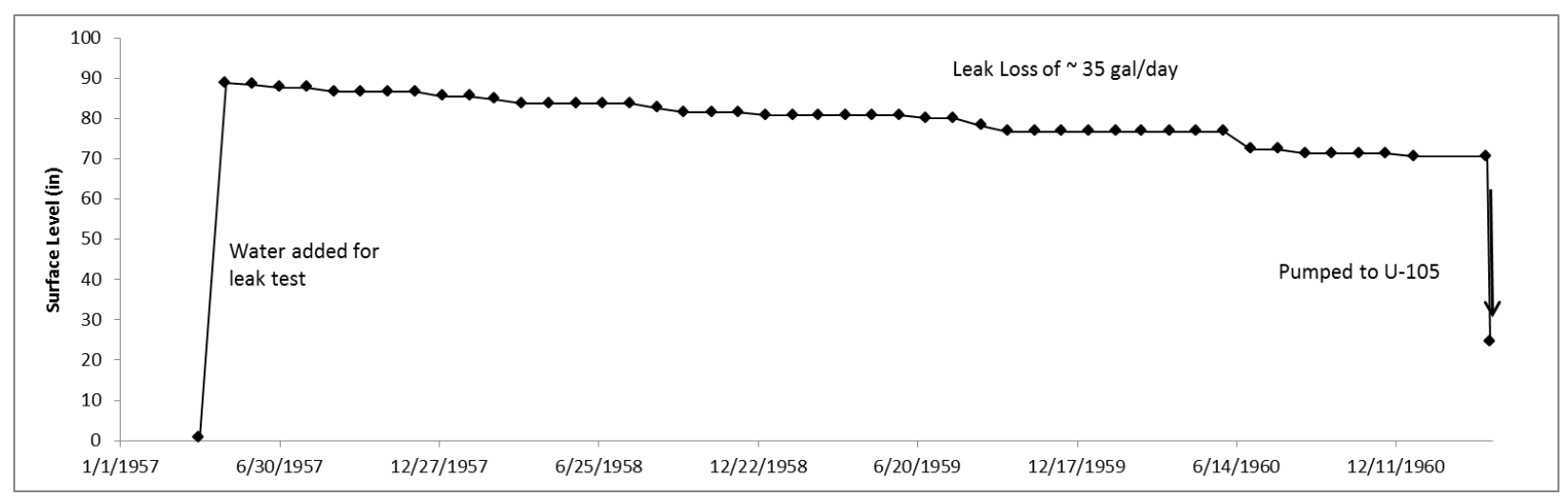

\subsubsection{Temperature}

No temperature data were recovered for tank U-104 from July 1947 when the tank was first put into service until June 1975. Tank U-104 waste temperature plots from 1975 to 1981 can be found in WHC-SD-WM-ER-325, however all of the plots (thermocouples 1 through 11) are identical and range between $\sim 55^{\circ} \mathrm{F}$ and $\sim 85^{\circ} \mathrm{F}$. The plots carry a footnote that the data was obtained from SACS (PCSACS); however, a query of PCSACS indicates that tank U-104 is not listed as available in the tank dropdown. Therefore, there does not appear to be any tank U-104 data available.

Condensers on the B, C, T, and U Farm tanks were reported to be adequate for the waste temperatures and vapor loads for the original operations at approximately $180^{\circ} \mathrm{F}$ for supernatant and sludge (WHC-MR-0132).

Five temperature data points between 1946 and November 1947 were found for Tank T-101 (HW-14946, A Survey of Corrosion Data and Construction Details, 200 Area Waste Storage Tanks). Tank T-101 contained MW from 221-T Plant two and a half years before tank U-104 began receiving MW from 221-T Plant. This provides a point of comparison to infer similar tank waste temperatures in tank U-104. The first temperature found for tank T-101 was recorded on May 29,1946 of $174^{\circ} \mathrm{F}$ which was taken eight months after the tank began cascading to tank $\mathrm{T}-102$. On that date as a point of comparison the waste temperature in tank T-102 was $126^{\circ} \mathrm{F}$ which accounts for cooling in the second cascade tank. Subsequent temperatures for tank T-101 ranged between $149^{\circ} \mathrm{F}$ and $153^{\circ} \mathrm{F}$ between November 1946 and November 1947. The tank U104 temperature for MW storage and sluicing, which would be similar to tank T-101, does not appear to have exceeded $180^{\circ} \mathrm{F}$ prior to the tank leak. Similar temperatures were experienced in tank B-101 the first tank in the cascade which first received MW from 221-B Plant.

The rate of temperature rise can result in increased vapor pressure under the bottom tank liner from moisture in the underlying grout and vapor from the asphalt membrane below the grout. The initial MW fill period occurred over $\sim 6$ months. Temperatures are not available so an actual rate of temperature rise is not available. It seems improbable that the rate of rise for this initial period would have caused a scenario that resulted in a bulge either during the storage period taking into account the hydrostatic head or at the end of the storage period when the hydrostatic head essentially was reduced to zero. The latter would have required trapping the vapor pressure 
under the liner for the more than 5 year storage period. There were no reports of bulging at the end of sluicing the initial MW when a heel jet would have been installed in the center riser to decrease the waste to the 2,000 gal volume. The second MW fill period occurred over less than two months which could have resulted in a higher temperature rate of rise, considering cooling of the empty tank over the preceding year when the tank was empty. There may have been some mechanism where small fissures in the liner allowed moisture to collect below the liner, somehow trapping the vapor during the yearlong storage period resulting in bulging the bottom liner when the tank was emptied, July 1956.

\subsubsection{Liner Observations}

A bulge in a tank liner may result in the direct failure of the liner or cause enough stress or thinning on the steel liner plates and welds that they become more susceptible to the effects of corrosion. Experience indicates that bulging tends to be a dynamic phenomenon, and it is possible that a tank with no measured bulge at one point in time may actually have had a displaced liner that was not detected at another time.

The tank U-104 MW sludge sluicing was halted after a failed installation of the heel jet through the pit at the center of the tank. It was determined by measurement that the center of the tank bottom was approximately 5-ft higher than normal (HW-45115 H, Separations Technology Section Monthly Report - August, 1956, page Fc-15) and thus, tank U-104 was suspected of leaking. A periscope was installed in the tank on July 26, 1956 for inspection which confirmed a liner bulge (HW-44024-RD; EM-TF-040.9a). A light assembly was installed in the tank the following week to permit better visibility and HW-44024-RD reported, "Subsequent inspections of the tank revealed a definite bulge in the center of the tank and what appeared to be a split in the steel plates of the bulged portion." Tank U-104 was the only known non-boiling waste SST that experienced a tank bottom bulge during this time (see Appendix A1).

Photographs were reported to be taken of the interior of tank U-104 on August 15, 1956 (HW44024-RD), and photographs confirmed the liner bulge (HW-45115 H, page Fc-15). However, the photographs did not indicate rupture of the liner although about half of the tank surface was covered with liquid (see Section 4.4.5). One of the retrieved photographs, Figure 4-5, seems to show the 5-ft bulged bottom liner with waste around upper quadrant. 
RPP-RPT-54915, Rev. 0

Figure 4-5. Tank U-104 Bulged Bottom Liner August 15, 1956 (Photograph 5BN1D0021185)

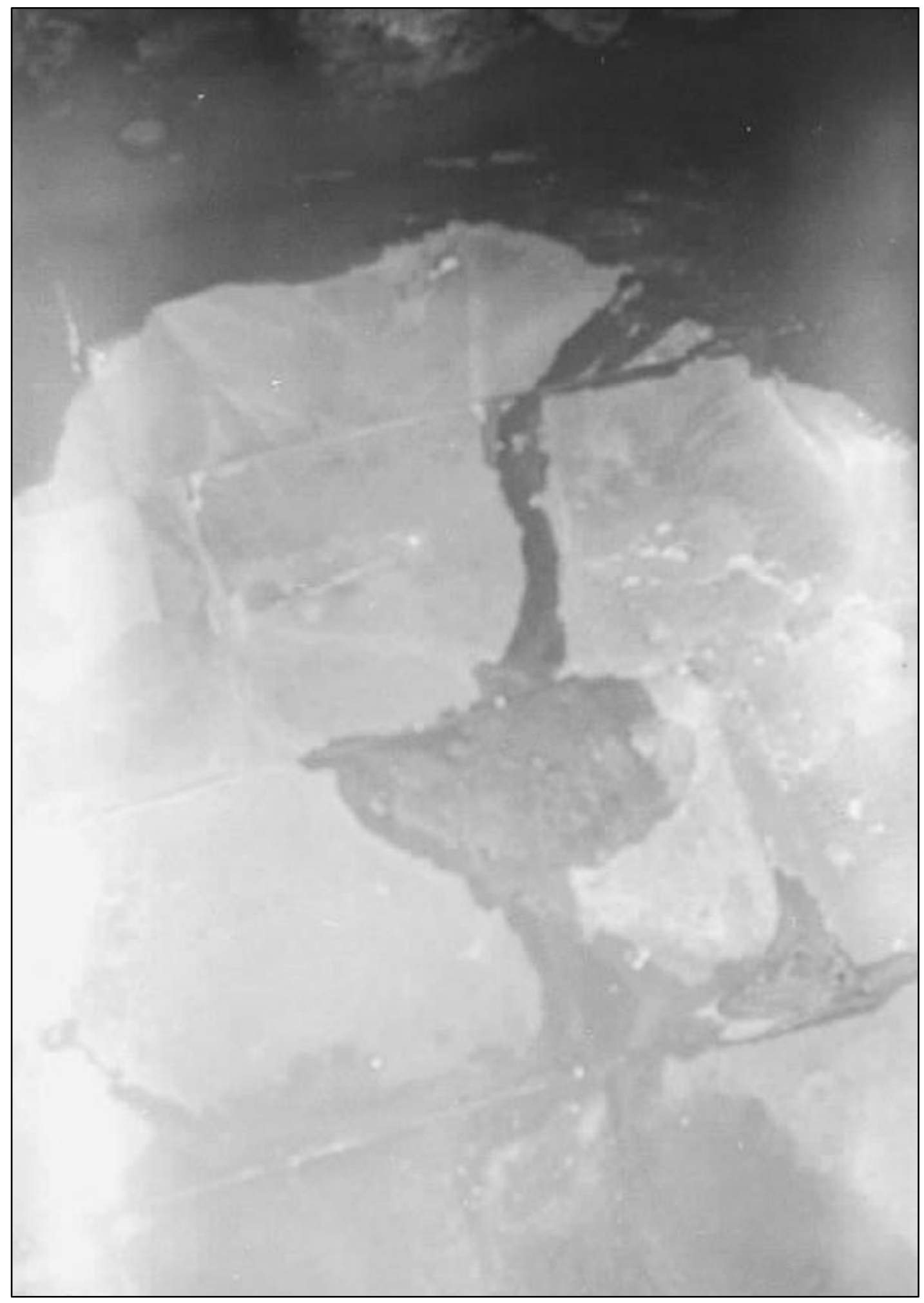




\subsubsection{Chemistry-Corrosion}

Tank U-104 began receiving waste in July 1947 and test water as shown in Table 4-1. The typical concentration for nitrite, nitrate, and hydroxide for MW waste is shown in Table 4-2. Nitrite and hydroxide are known as nitrate induced SCC inhibitors. One key characteristic for inhibiting SCC is to maintain a high nitrite concentration to nitrate concentration ratio (see Section 3.2.4).

Table 4-1. Tank U-104 Waste Storage Chronology

\begin{tabular}{|c|c|c|}
\hline Date & Waste Type & Length of Storage \\
\hline July 1947 to July 1956 & MW & $\sim 8$ years \\
\hline April 1957 to March 1961 & Water & $\sim 4$ years \\
\hline
\end{tabular}

Table 4-2. Waste Chemistries for Waste Types Stored in Tank U-104

\begin{tabular}{|c|c|c|c|c|}
\hline Waste Type & {$\left[\mathrm{NO}_{3}{ }^{-}\right]$} & {$\left[\mathrm{NO}_{2}{ }^{-}\right]$} & {$\left[\mathrm{OH}^{-}\right]$} & $\begin{array}{c}\text { Meets Current DST } \\
\text { Specification }\end{array}$ \\
\hline $\mathrm{MW}$ & & & & Yes $^{3}$ \\
\hline
\end{tabular}

1. Reference WHC-EP-0449, 1991, The Sort on Radioactive Waste Type Model: A Method to Sort Single-Shell Tanks into Characteristic Groups.

2. Reference OSD-T-151-00007, Rev. 12, 2013, Operating Specification for the Double-Shell Storage Tanks.

3. Even with no reported value for nitrite, the ratio of nitrate to nitrite and hydroxide would still be less than 2.5 as stated in the current DST specification.

Metal waste should not be a concern for either pitting or SCC under the tank U-104 conditions.

\subsubsection{Photographs}

Photographs were reported to be taken of the interior of tank U-104 on August 15, 1956 that confirmed a liner bulge (see Section 4.4.3). One of the retrieved photographs seems to show the bulged bottom liner. The next set of available photographs for tank U-104 was dated November 14, 1967. These photographs focused on the tank sidewall so a view of the waste surface was not available. These were the only sets of photographs taken prior to the addition of diatomaceous earth in May 1972 that could be located. No other anomalies were indicated from a review of available tank U-104 photographs.

\subsection{TANK U-104 EX-TANK DATA}

\subsubsection{Drywells}

There are six drywells located around tank U-104: 60-04-03, 60-07-11, 60-04-08, 60-04-10, and 60-04-12, installed in 1974, and 60-07-01, installed in 1976 in addition to two direct pushes installed in 2007. All of the radiation readings in drywells are assumed to be maximum or peak readings unless otherwise noted (see Section 3.3.2). The following subsections report the available drywell information and the drywell summary section provides the analyses of the associated drywells with tank U-104. 


\subsubsection{Drywell 60-04-03}

Drywell 60-04-03 is located approximately 2.2-ft from the tank U-104 footing. Drywell 60-0403 was drilled in 1974 with the first recoverable reading on October 4, 1974 reported as less than values (see Appendix B1). Readings continued to be reported as less than values through June 1986.

In July 1996, Cs-137 was the only man-made radionuclide detected in this drywell (GJ-HAN-33, Vadose Zone Characterization Project at the Hanford Tank Farms Tank Summary Data Report for Tank U-104). From the ground surface to 10-ft BGS, Cs-137 was detected continuously, intermittently from 10 to $15-\mathrm{ft}$ BGS, at a few isolated locations, and at the bottom of the drywell. The maximum Cs-137 concentration was approximately $0.8 \mathrm{pCi} / \mathrm{g}$ at 3-ft BGS. Document GJHAN-33 reports, "The Cs-137 contamination resulted from a surface spill or leak from ancillary piping that migrated downward."

Since historical radioactivity in this drywell is very low, and GJ-HAN-33 reported low levels of radioactivity, drywell 60-04-03 is not being included as part of the leak location for tank U-104. Figure 4-6 shows the depths of radioactivity from 1975 to 1995 (RPP-7729, Analysis \& Summary Report of Historical Drywell Gamma Logs for 241-U Tank Farm - 200 West).

Figure 4-6. Tank U-104 Drywell 60-04-03 (RPP-7729)

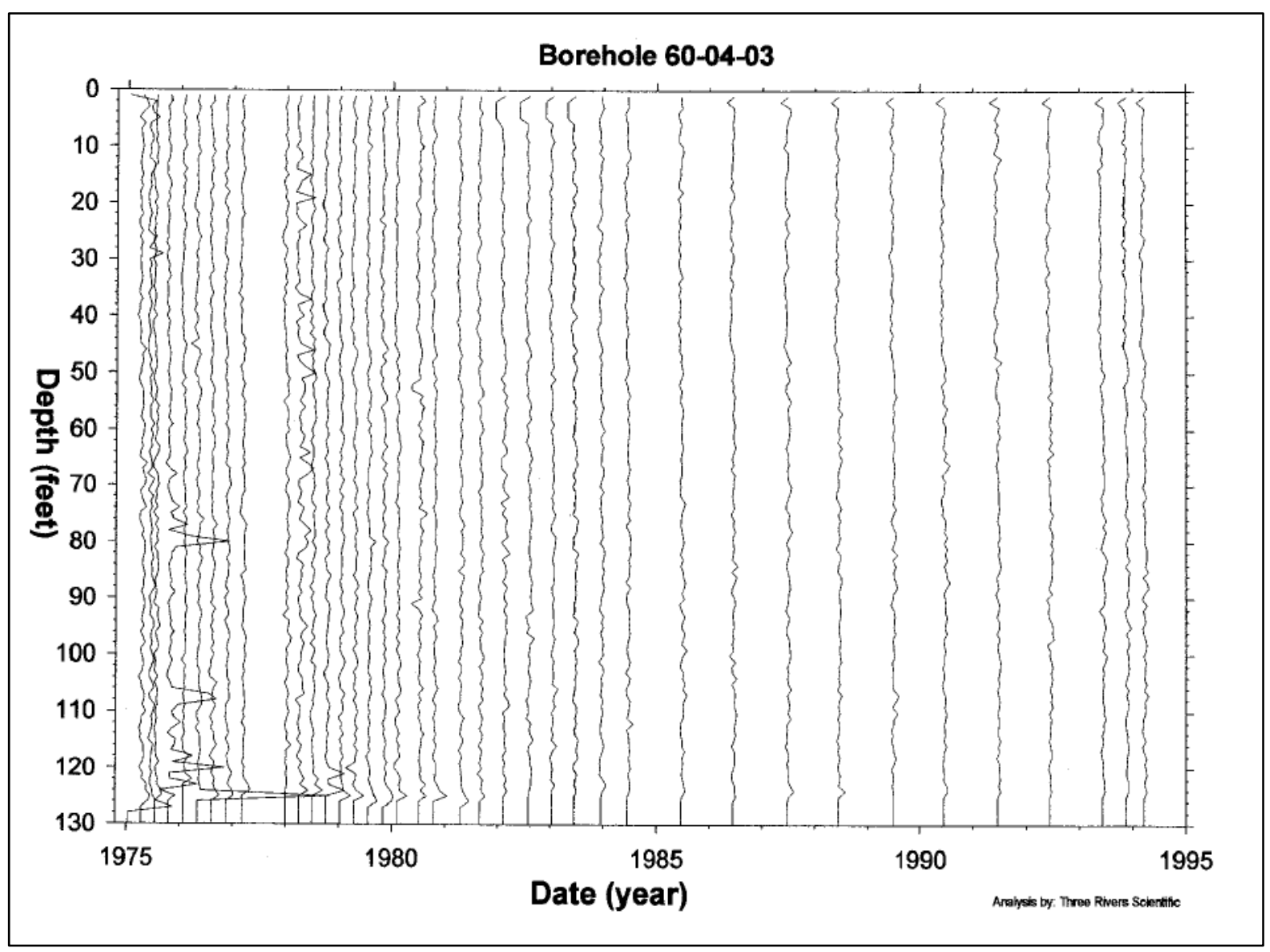

Note: Bottom of the tank footing is $\sim 38$-ft 4-in BGS 


\subsubsection{Drywell 60-07-01}

Drywell 60-07-01 is located approximately 15.7-ft from the tank U-104 footing. Drywell 60-0701 was drilled in 1976 with the first recoverable reading on May 12, 1976 with a peak 13-ft below the bottom base of the tank of $4 \mathrm{~K} \mathrm{cpm}$ at 51-ft BGS (see Appendix B1). Radioactivity levels remained relatively stable at this BGS depth through November 1986.

In July 1996, Cs-137 and processed U-235 and U-238 (or from waste associated with processed uranium fuel materials) were the only man-made radionuclides detected in drywell 60-07-01 (GJ-HAN-33). From the ground surface to 14-ft BGS, Cs-137 contamination was detected intermittently. The maximum concentration of $9 \mathrm{pCi} / \mathrm{g}$ was reported at $0.5-\mathrm{ft} \mathrm{BGS}$ which was the result of a surface spill or leak from ancillary piping (GJ-HAN-33).

Processed U-235 was detected continuously from 52 to 57-ft BGS, 73 to 77-ft BGS, intermittently between these two zones, and slightly below the lower zone. The maximum concentration of $9 \mathrm{pCi} / \mathrm{g}$ was measured at a depth of 55-ft BGS, 17-ft below the base of the tank. Processed U-238 was measured between 52 and 56-ft BGS at concentrations ranging between 100 and $200 \mathrm{pCi} / \mathrm{g}$. Document GJ-HAN-33 states, "The processed U-235 and U-238 contamination most likely resulted from leakage from tank U-104." Figure 4-7 shows the depths of radioactivity from 1975 to 1995 (RPP-7729).

Figure 4-7. Tank U-104 Drywell 60-07-01 (RPP-7729)

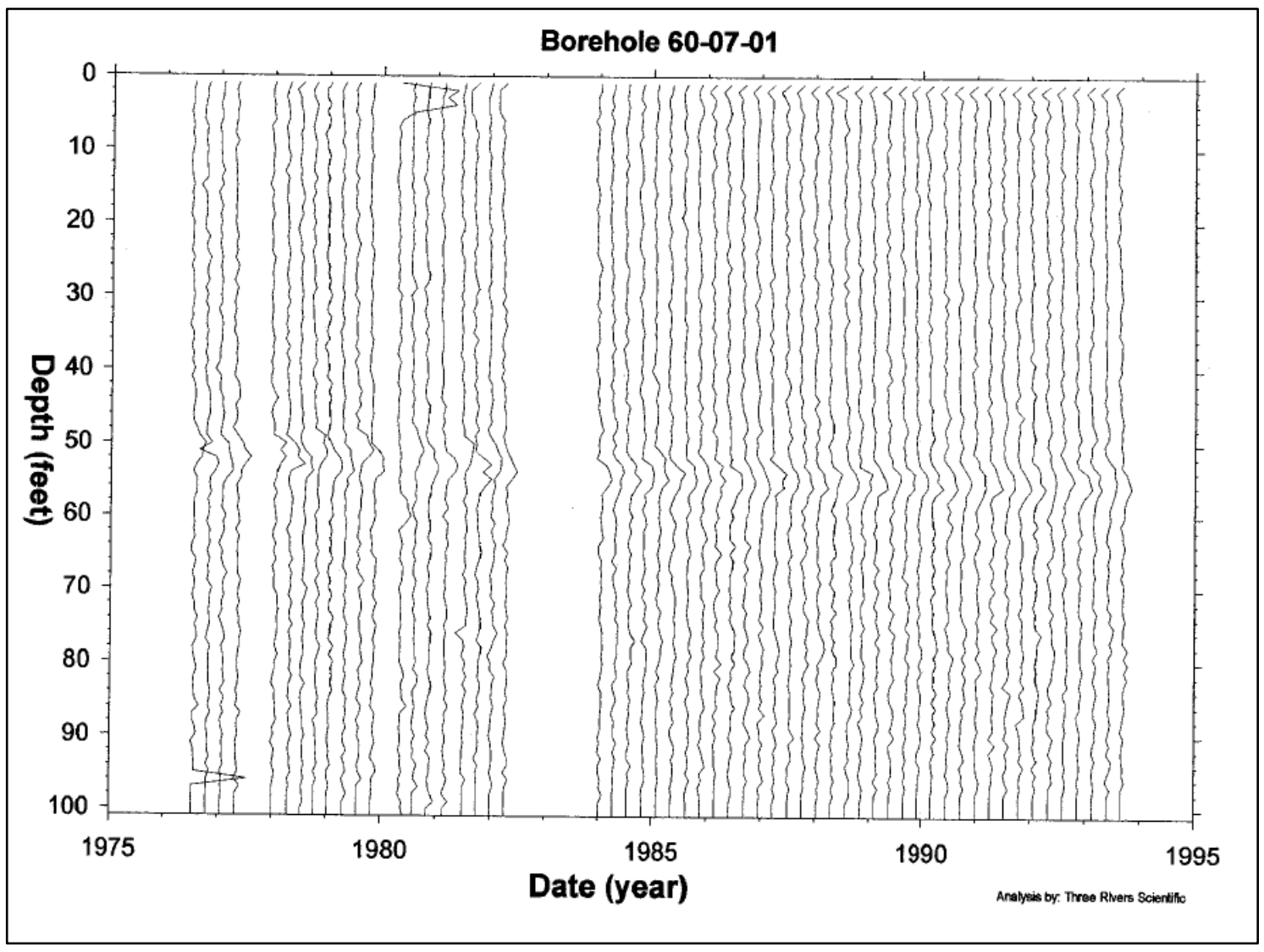

Note: Bottom of the tank footing is $\sim 38$-ft 4 -in BGS 


\subsubsection{Drywell 60-07-11}

Drywell 60-07-11 is located approximately 15.7-ft from the tank U-104 footing. Drywell 60-0711 was drilled in 1974 with the first recoverable readings reported on June 4, 1974 with a peak $12-\mathrm{ft}$ below the bottom base of the tank of $73.8 \mathrm{~K} \mathrm{cpm}$ at $50-\mathrm{ft}$ BGS (see Appendix B1). The next recoverable reading on July 18,1974 reported a peak at $15.2 \mathrm{~K}$ cpm at 53-ft BGS. Readings remained relatively stable through November 1986 at this BGS depth.

In July 1996, Cs-137 and processed U-235 and U-238 were the only man-made radionuclides detected in drywell 60-07-11 (GJ-HAN-33). Cs-137 was detected continuously from the ground surface to 8-ft BGS, from 13 to $17-\mathrm{ft}$ BGS, at a few isolated locations, and at the bottom of the drywell. The maximum Cs-137 concentration of approximately $20 \mathrm{pCi} / \mathrm{g}$ was detected at $1-\mathrm{ft}$ BGS which resulted from a surface or near-surface spill, leak from piping that migrated downward, and/or was carried down when the drywell was drilled (GJ-HAN-33). Processed U235 was detected from 52 to 82-ft BGS and from 83 to 93-ft BGS with the maximum concentration of $80 \mathrm{pCi} / \mathrm{g}$ measured at 53-ft BGS, 15-ft below the base of the tank.

Processed U-238 was detected at depths from 52 to $69-\mathrm{ft}$, from 70 to $82-\mathrm{ft}$, and from 83 to $93-\mathrm{ft}$ BGS. The maximum U-238 concentration of more than $1,000 \mathrm{pCi} / \mathrm{g}$ was measured at $53-\mathrm{ft}$ BGS. Document GJ-HAN-33 reported, "The processed U-235 and U-238 contamination most likely resulted from leakage from tank U-104." Figure 4-8 shows the depths of radioactivity from 1975 to 1995 (RPP-7729).

Figure 4-8. Tank U-104 Drywell 60-07-11 (RPP-7729)

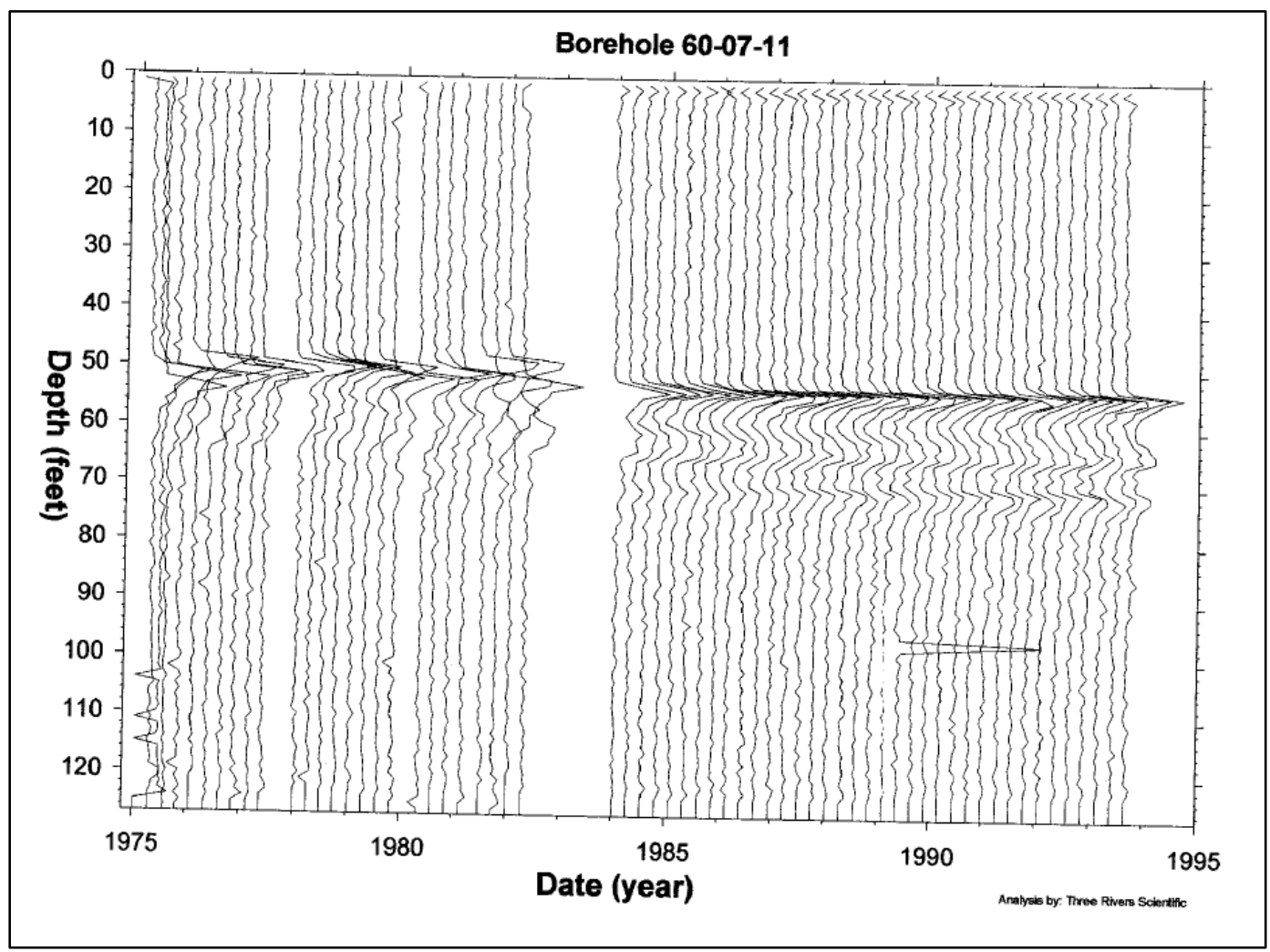

Note: Bottom of the tank footing is $~ 38$-ft 4 -in BGS 


\subsubsection{Drywell 60-04-08}

Drywell 60-04-08 is located approximately 5.2-ft from the tank U-104 footing. Drywell 60-0408 was drilled in 1974 with the first recoverable reading on June 4, 1974 with a peak 15-ft below the bottom base of the tank of $70.8 \mathrm{~K} \mathrm{cpm}$ at 53-ft BGS (see Appendix B1). The next reading reported on July 1, 1974 reported the peak at $17.8 \mathrm{~K}$ cpm at $49-\mathrm{ft}$ BGS. Radioactivity remained relatively stable at this BGS depth through September 1986.

In July 1996, Cs-137 and processed U-235 and U-238 were the only man-made radionuclides detected in drywell 60-04-08 (GJ-HAN-33). Continuous Cs-137 contamination was detected from the ground surface to 22-ft BGS with the maximum concentration of $8 \mathrm{pCi} / \mathrm{g}$ measured at 2$\mathrm{ft}$ BGS which resulted from a surface or near-surface spill, leak from piping that migrated downward, and/or was carried down when the drywell was drilled (GJ-HAN-33).

Processed U-235 was detected from 53 to 65-ft BGS and from 70 to 76-ft BGS with the maximum U-235 concentration of approximately $20 \mathrm{pCi} / \mathrm{g}$ reported at $53-\mathrm{ft}$ BGS. Processed U238 was detected from 53 to 65 -ft BGS, from 68 to 78-ft BGS, and at a few isolated locations. The maximum U-238 concentration of $500 \mathrm{pCi} / \mathrm{g}$ was measured at 53-ft BGS, 15-ft below the base of the tank. Document GJ-HAN-33 reports, "The processed U-235 and U-238 contamination most likely resulted from leakage from tank U-104." Figure 4-9 shows the depths of radioactivity from 1975 to 1995 (RPP-7729).

Figure 4-9. Tank U-104 Drywell 60-04-08 (RPP-7729)

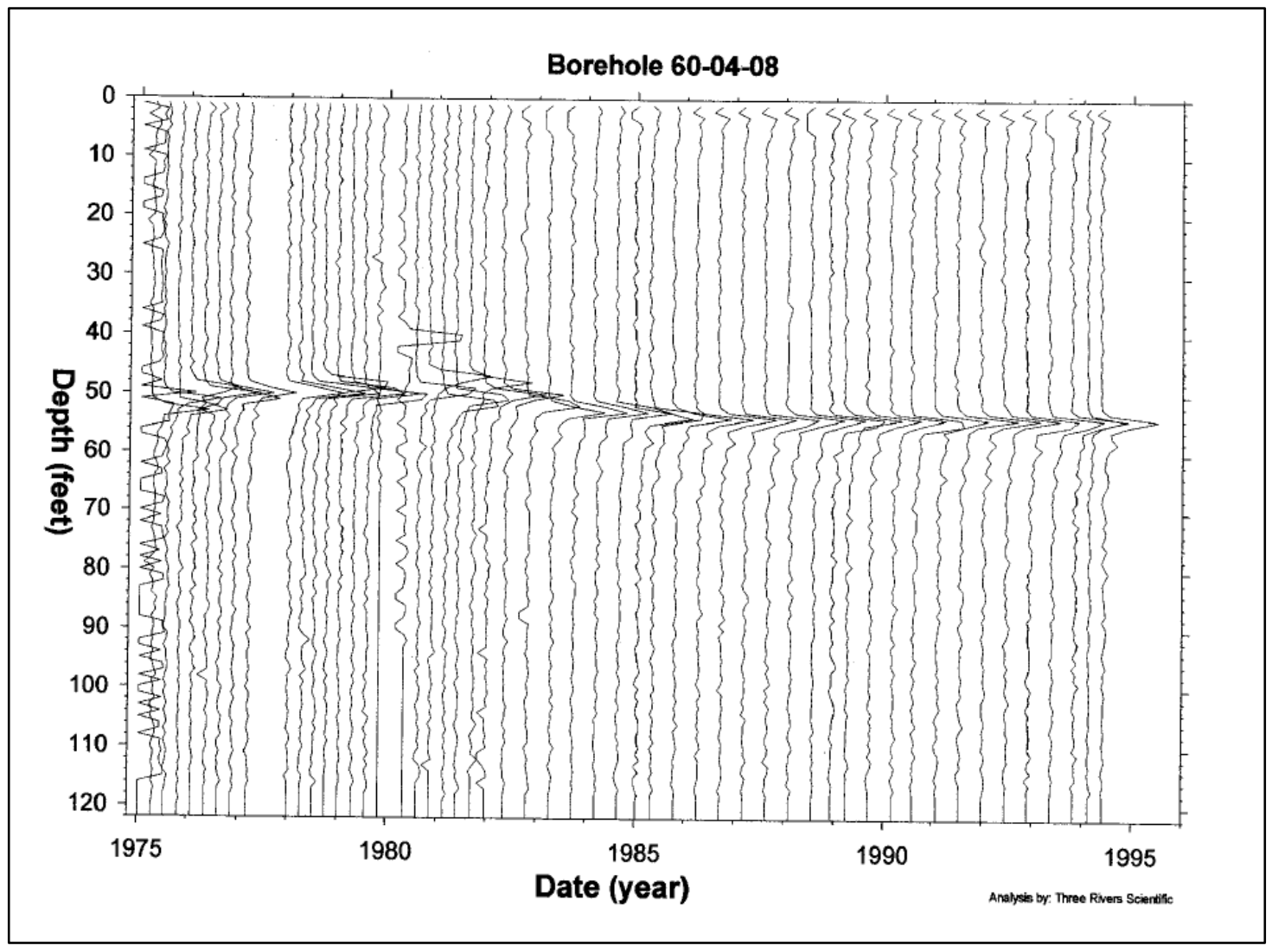

Note: Bottom of the tank footing is $\sim 38$-ft 4-in BGS 


\subsubsection{Drywell 60-04-10}

Drywell 60-04-10 is located approximately 6.2-ft from the tank U-104 footing. Drywell 60-0410 was drilled on 1974 with the first recoverable reading on April 18, 1974 with a peak of $15.6 \mathrm{~K}$ cpm at 56-ft BGS (see Appendix B1). The next recorded reading on June 4, 1974 reported a peak 15 -ft below the bottom base of the tank of $13.8 \mathrm{~K} \mathrm{cpm}$ at $53-\mathrm{ft}$ BGS. Four days later, the radioactivity peak at $49-\mathrm{ft}$ BGS was reported at approximately $3 \mathrm{~K} \mathrm{cpm}$. Radioactivity remained relatively stable through November 1986 at this BGS depth.

In July 1996, Cs-137 and processed U-235 and U-238 were the only man-made radionuclides detected in drywell 60-04-10 (GJ-HAN-33). Cs-137 was detected continuously from the ground surface to 5-ft BGS and at a few intermittent locations. The maximum Cs-137 concentration of approximately $6 \mathrm{pCi} / \mathrm{g}$ was detected at 1-ft BGS which was the result from a surface or nearsurface spill or leak from piping that migrated downward (GJ-HAN-33). Processed U-235 was detected from 53 to 55-ft BGS, 66 to 67-ft BGS, and at a few isolated locations with the maximum concentration of $10 \mathrm{pCi} / \mathrm{g}$ measured at 54-ft BGS. Processed U-238 was detected from 53 to 56-ft BGS and from 65 to $67-\mathrm{ft}$ BGS with the maximum concentration of $150 \mathrm{pCi} / \mathrm{g}$ measured at 54-ft BGS. Document GJ-HAN-33 reported, "The processed U-235 and U-238 contamination most likely resulted from leakage from tank U-104." Figure 4-10 shows the depths of radioactivity from 1975 to 1995 (RPP-7729).

Figure 4-10. Tank U-104 Drywell 60-04-10 (RPP-7729)

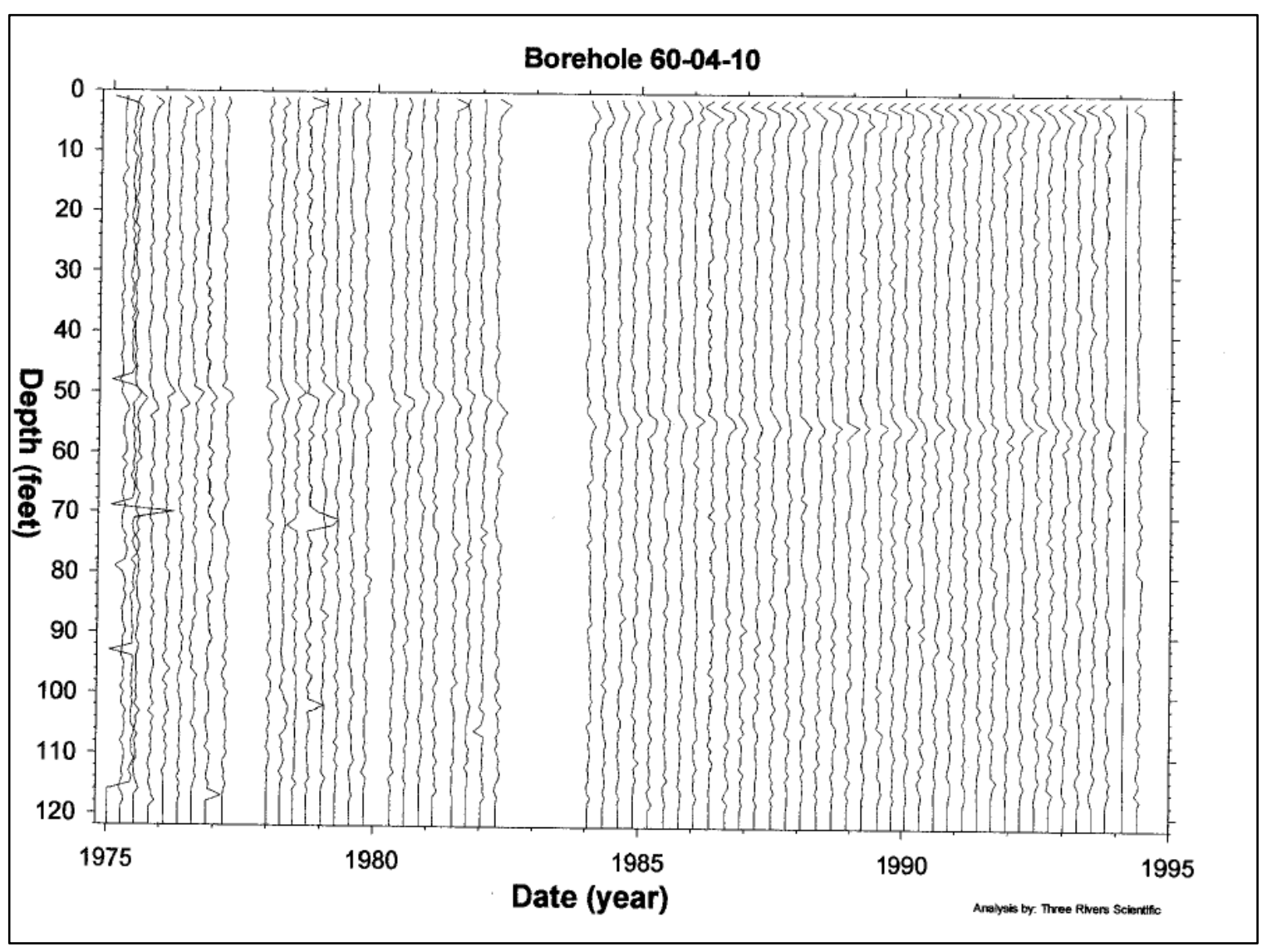

Note: Bottom of the tank footing is $\sim 38$-ft 4 -in BGS 


\subsubsection{Drywell 60-04-12}

Drywell 60-04-12 is located approximately 6.6-ft from the tank U-104 footing. Drywell 60-0412 was drilled in 1974 with the first recoverable reading on April 18, 1974 reported as less than values (see Appendix B1). Readings continued to be reported as less than values through June 1986.

In July 1996, Cs-137 was the only man-made radionuclides detected in drywell 60-04-12 (GJHAN-33). Cs-137 was detected continuously from the ground surface to 18-ft BGS, intermittently from 24 to $31-\mathrm{ft}$ BGS, at a few isolated locations, and at the bottom of the drywell. The maximum Cs-137 concentration of $4 \mathrm{pCi} / \mathrm{g}$ was detected at a depth of 9 -ft BGS. Document GJ-HAN-33 reports, "This contamination resulted from a surface or near-surface spill or leak that migrated downward." Since historical radioactivity in this drywell is very low, and the 1996 SGLS report low levels of radioactivity, drywell 60-04-12 is not being included as part of the leak location for tank U-104. Figure 4-11 shows the depths of radioactivity from 1975 to 1995 (RPP-7729).

Figure 4-11. Tank U-104 Drywell 60-04-12 (RPP-7729)

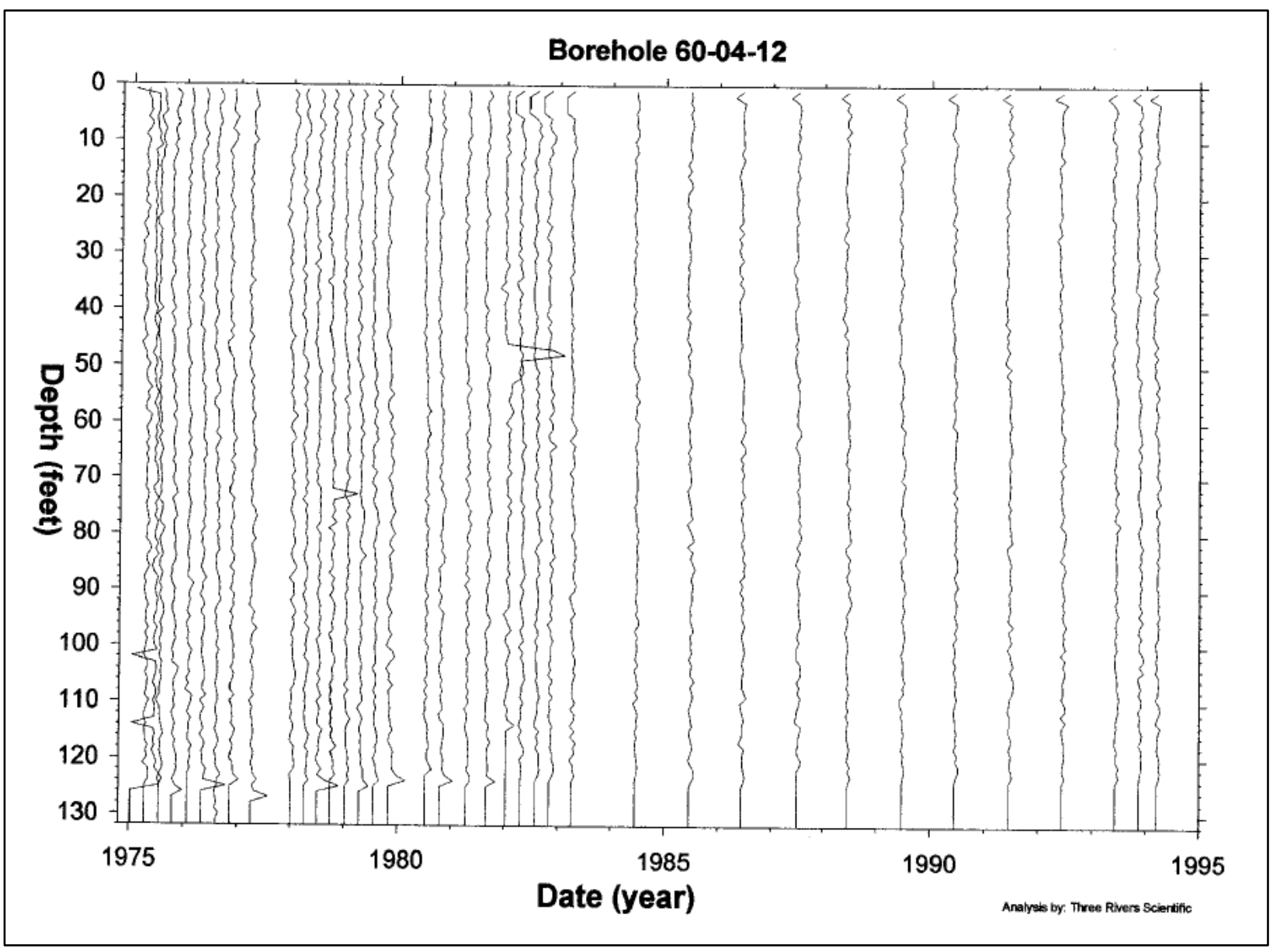

Note: Bottom of the tank footing is $\sim 38$-ft 4 -in BGS 
RPP-RPT-54915, Rev. 0

\subsubsection{2007 Direct Pushes}

In 2007, two direct pushes (C5593 and C5601) were installed near tank U-104 for spectral gamma logging (see Figure 4-1).

Results identified Cs-137 as the dominant gamma emitting radionuclide in direct push C5593 with a maximum equivalent Cs-137 concentration of $150 \mathrm{pCi} / \mathrm{g}$ detected at 24-ft BGS (RPP36007, Rev. 0, Small Diameter Geophysical Logging in the 241-U Tank Farm). This appears to be a separate unrelated leak site from the earlier drywell data due to timing and depth and may be associated with a pipeline leak. The source does not appear to be from tank U-104 as only lowlevel radioactivity was detected in nearby drywells 60-04-12 and 60-04-03. However, a tank U104 leak cannot be ruled out.

The maximum Cs-137 concentration detected in direct push C5601 was $24 \mathrm{pCi} / \mathrm{g}$ at 52-ft BGS (RPP-36007, Rev. 0). Radioactivity detected in this direct push appears to be related to the drywell radioactivity detected in the southern portion of the tank in 1974 due to the similar depths where maximum concentrations were recorded.

\subsubsection{Drywell Summary}

Tank U-104 was first suspected of leaking during sluicing operations in July 1956 (see Section 4.4.1). Drywells were not installed near tank U-104 until 1974.

Tank U-104 drywells 60-04-03 and 60-04-12 do not indicate any radioactivity associated with a tank U-104 leak. Therefore, these drywells are not included in the leak location for tank U-104.

The first recoverable readings in 1974-1976 for drywells 60-04-08, 60-04-10, 60-07-01, and 6007-11 indicate radioactivity. A peak was reported in drywells 60-07-11 and 60-04-08 at around the same intensity $(\sim 70 \mathrm{~K} \mathrm{cpm})$ and similar depths ( 50-ft BGS). Radioactivity peaks of much lower intensity was reported in drywell 60-07-01 (4K cpm at 51-ft BGS) and drywell 60-04-10 (15.6K cpm at 56-ft BGS). Uranium reported in these four drywells (GJ-HAN-33) appears to be associated with a tank U-104 leak. Direct push C5601, installed in 2007, reports Cs-137 at a similar depth (52-ft BGS). It appears the source of the uranium detected in these four drywells and possibly the Cs-137 detected in direct push C5601 is from tank U-104.

Direct push C5593, installed in 2007, reports maximum radioactivity (150 pCi/g equivalent Cs137) detected at 24-ft BGS. The source does not appear to be from tank U-104 as very little radioactivity was reported in nearby drywells 60-04-03 and 60-04-12 and may be associated with a pipeline leak. In addition the radioactive profile doesn't fit the profile of the radioactivity in the other drywells, however, a tank U-104 leak source cannot be ruled out. No laterals were installed near tank U-104.

\subsection{POSSIBLE TANK U-104 LINER LEAK LOCATION(S)}

A liner leak may have penetrated the waterproof membrane at any location or pooled on the waterproof membrane and followed concrete cracks or construction joints to a different location for egress to the soil, including the top of the tank footing. 
Tank U-104 was first suspected of leaking at the end of sluicing operations in July 1956 when the tank bulge was detected during the installation of a jet pump in the center riser. A subsequent leak test was performed between April 1957 and March 1961 confirmed a liner leak. Drywells were installed 1974 and two direct pushes in 2007. Tank U-104 had at least one liner leak site based on radioactivity detected in four drywells and two direct pushes, likely at or near the bottom of the tank.

\subsubsection{Leak Detected in 1974-1976}

Tank U-104 was first suspected of leaking during sluicing operations in July 1956 (see Section 4.4.1). Drywells were not installed near tank U-104 until 1974.

The first recoverable readings in 1974-1976 for drywells 60-04-08, 60-04-10, 60-07-01, and 6007-11 indicate radioactivity. A peak was reported in drywells 60-07-11 and 60-04-08 at around the same intensity $(\sim 70 \mathrm{~K} \mathrm{cpm})$ and similar depths ( 50-ft BGS). Radioactivity at much lower intensity was reported in drywells 60-07-01 and 60-04-10 at similar BGS depths. The uranium detected in these four drywells appears to be associated with a tank U-104 leak. Direct push C5601, installed in 2007, reported radioactivity at a similar depth (52-ft BGS). The peak uranium detected in these drywells at approximately the 50-ft BGS level is roughly 12-ft lower than the bottom of the tank footing indicating some sort of transport mechanism during the 18-yr period when the leak was first suspected to the first drywell data. It appears the source of the radioactivity detected in these four drywells and direct push C5601 are related and indicate a tank U-104 leak in the southwestern portion of the tank (see Figure 4-12). 
RPP-RPT-54915, Rev. 0

Figure 4-12. Tank U-104 Possible Leak Location (1974-1976)

Tank inner ring is steel liner; outer ring is outer edge of tank footing

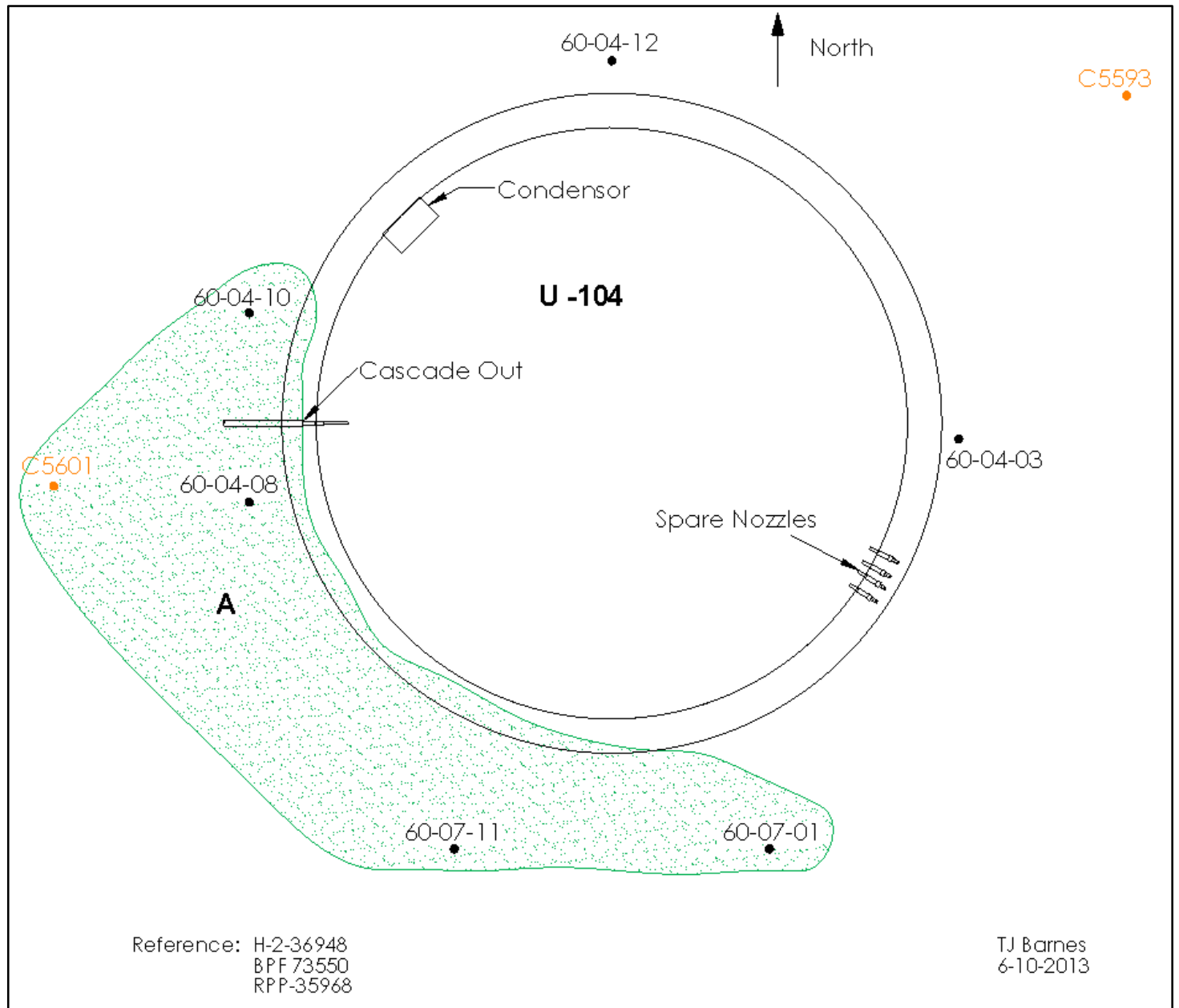

Tank U-104 was first suspected of leaking during sluicing operations in July 1956 (see Section 4.4.1). Drywells were not installed near tank U-104 until 1974. 


\subsubsection{Leak Detected in 2007}

Direct push C5593, installed in 2007, reports maximum radioactivity (150 pCi/g equivalent Cs137) detected at 24-ft BGS (see Figure 4-13). The source may be associated with a pipeline leak as it does not appear to be from tank U-104 since very little radioactivity was reported in nearby drywells 60-04-03 and 60-04-12 and radioactivity reported in this direct push was located at a much higher BGS level compared to site A in Figure 4-12. The source of this radioactivity remains unknown; however, a tank U-104 leak source cannot be ruled out.

Figure 4-13. Tank U-104 Possible Leak Location (2007)

Tank inner ring is steel liner; outer ring is outer edge of tank footing

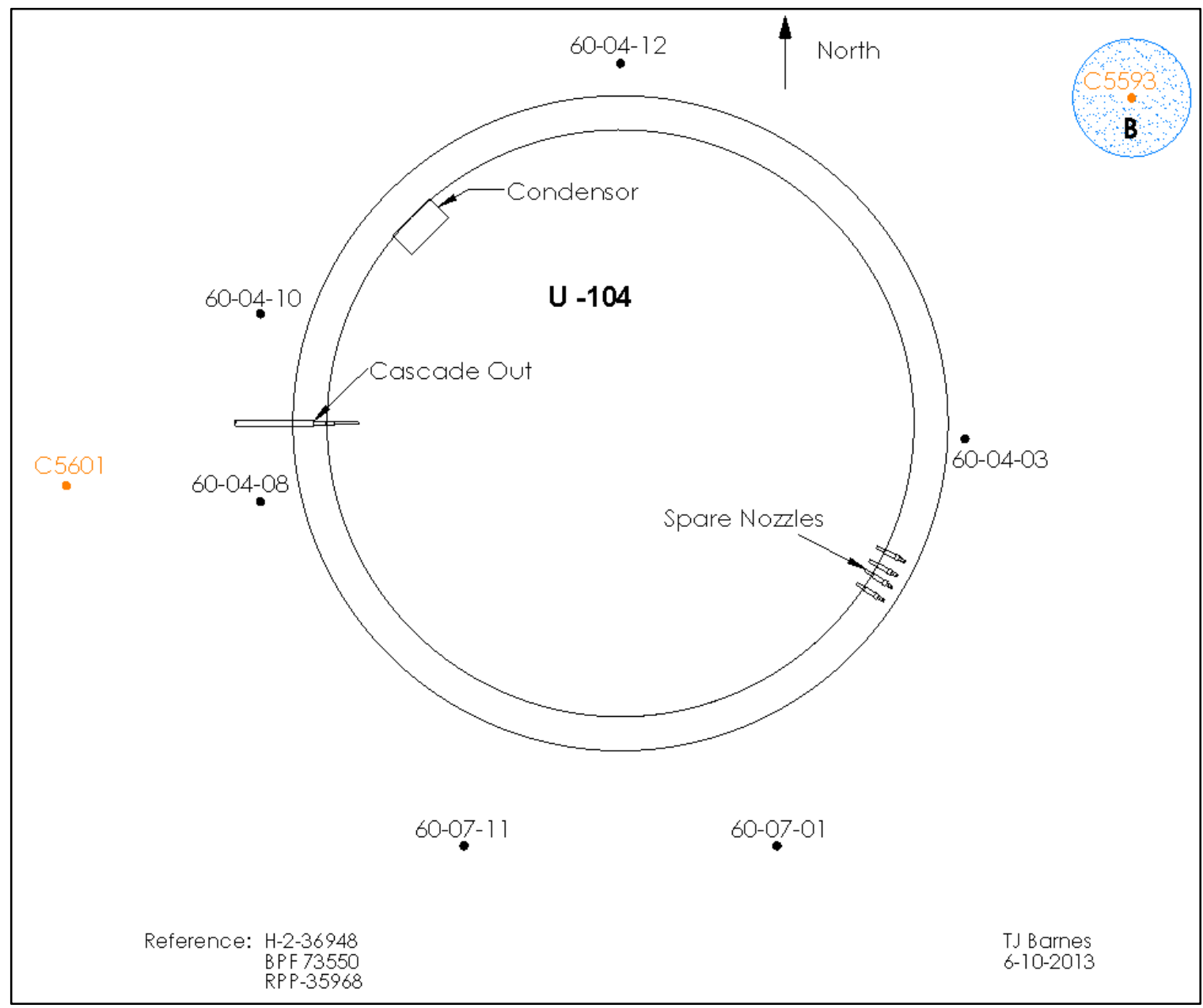

Tank U-104 was first suspected of leaking during sluicing operations in July 1956 (see Section 4.4.1). Drywells were not installed near tank U-104 until 1974. 


\subsubsection{Leak Location Summary}

Tank U-104 was first suspected of leaking during sluicing operations in July 1956. A leak test was conducted from April 1957 through March 1961 where a volume of approximately $50 \mathrm{kgal}$ was lost (see Section 4.4.1). During this time, no drywells were installed around tank U-104 to confirm a liner leak.

The first recoverable readings in 1974-1976 for drywells 60-04-08, 60-04-10, 60-07-01, and 6007-11 indicate radioactivity at a depth ranging from 50-56-ft BGS. Gross gamma activity was higher in drywells 60-07-11 and 60-04-08 indicating the leak was closer to these drywells. Direct push C5601, installed in 2007, reports radioactivity at a similar depth (52-ft BGS). The peak uranium detected in these drywells starting at approximately the 50-ft BGS level is roughly 12-ft lower than the bottom of the tank footing indicating some sort of transport mechanism during the 18-yr period when the leak was first suspected to the first drywell data. It appears the source of the radioactivity detected in these four drywells and direct push C5601 are related and indicate a tank U-104 leak in the southwestern portion of the tank (see site A in Figure 4-14).

Direct push C5593, installed in 2007, reports maximum radioactivity (150 pCi/g equivalent Cs137) detected at 24-ft BGS (see site B in Figure 4-14). The source may be associated with a pipeline leak as it does not appear to be from tank U-104 since very little radioactivity was reported in nearby drywells 60-04-03 and 60-04-12. The source of this radioactivity is unknown, therefore a tank U-104 leak source cannot be ruled out.

Leak locations in Figure 4-14 are based on peak readings and are a representation of possible initial boundaries of radioactivity.

Tank U-104 was reported to have bulged after a failed installation of the heel jet through the pit at the center of the tank during sluicing operations in July 1956. It was determined that the center of the tank bottom was $\sim 5$-ft higher than normal (see Section 4-11). Photographs were taken of the interior of tank U-104 on August 15, 1956 which confirmed the liner bulge (see Section 4.4.5). 
Figure 4-14. Tank U-104 Possible Radial Leak Locations

Tank inner ring is steel liner, outer ring is outer edge of tank footing

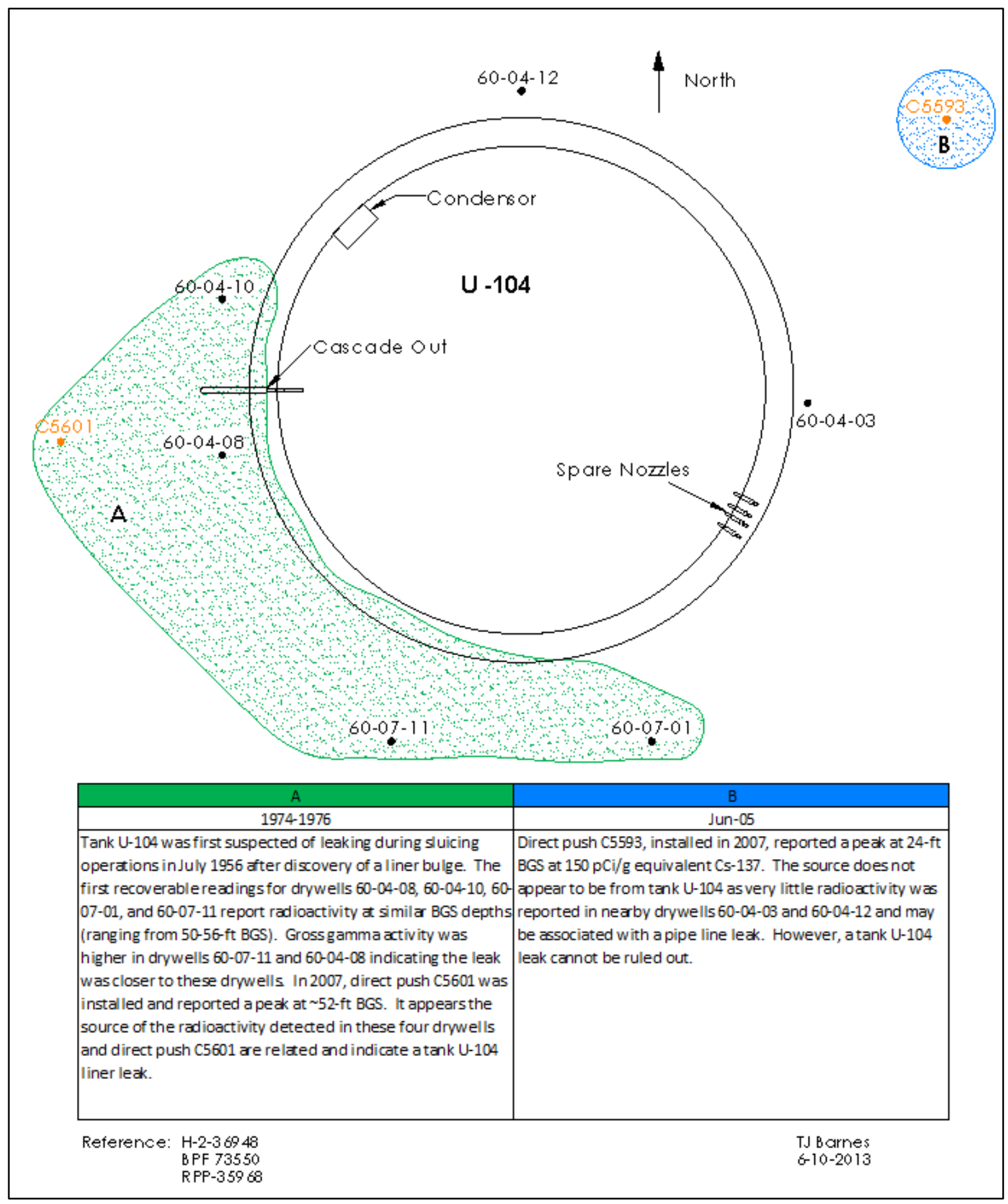


RPP-RPT-54915, Rev. 0

\subsection{POSSIBLE TANK U-104 LINER LEAK CAUSE(S)}

Tank U-104 was evaluated for five conditions known to contribute to a failed liner.

\subsubsection{Tank Design}

The U Farm tank design does not appear to be a factor contributing to a failed liner (see Section 3.1.1).

\subsubsection{Thermal Conditions}

No temperature data are available for tank U-104, however, tank U-104 held only non-boiling waste. Thermal shock creates stress both from rapid temperature rise as well as waste-induced high temperatures. Since no records are available, it is uncertain what the maximum temperature was in tank U-104 during operation as well as the rate of temperature rise when waste was added. The thermal attributes of the waste and other information (see Section 4.4.2) would indicate that thermal stresses were likely minimal and should not have challenged the tank storage limits. However, the rate of temperature rise could have resulted in vapor pressure under the liner overcoming the hydrostatic pressure.

Temperature requirements in ARH-951 issued December 18, 1969 indicated that tank temperatures should be held below $230^{\circ} \mathrm{F}$.

\subsubsection{Chemistry-Corrosion}

Tank U-104 stored MW for $\sim 8$ years before the liner leak. Metal waste should not have resulted in pitting or SCC under tank U-104 conditions.

\subsubsection{Liner Observations}

Tank U-104 was the first SST reported to have a liner bulge (July 1956) after a failed attempt to install a heel jet through the pit at the center of the tank during sluicing operations. Confirmation of the possible 5-ft liner bulge was reported in multiple documents (see Sections 4.4.3 and 4.4.5). A review of available photographs appears to confirm liner bulging reports. The tank had stored and sluiced MW twice up to a total of eight years prior to the discovery of the bulge.

Liner bulging coupled with other tank conditions could affect tank liner integrity, however, by itself bulging induces stresses that can cause breaching of the tank liner (see Section 3.2.3).

\subsubsection{Tank Construction Temperature}

The U Farm tank liners were constructed between February 1944 and October 1944. Only isolated minimum temperatures were experienced during tank construction at or below $18^{\circ} \mathrm{F}$ with day time temperatures between $44^{\circ} \mathrm{F}$ and $57^{\circ} \mathrm{F}$ (see Section 4.3.2). Impact occurrences could have occurred during cold temperatures that may have triggered fissures in the steel liner; however, the possibility seems much less than that which might have occurred during construction in other tank farms. 


\subsection{TANK U-104 CONCLUSIONS}

A 5-ft bulge in the tank U-104 bottom liner was discovered while completing the second sluicing of the full tank of MW in July 1956. The bulge with probable failure of the tank bottom liner resulted in a leak of waste to the soil under the tank towards the southwest. The cause of the bulge is not clear although there is a likely possibility related to rate of temperature rise which under the right conditions can cause vapor pressure under the liner to overcome hydrostatic pressure resulting in a bottom liner bulge. Subsequent leak testing with water confirmed the presence of a leak in the liner as well as detection of drywell radioactivity.

There are several liner leak cause conditions that were examined but the most likely cause of the tank U-104 liner leak was a 5-ft bulge in the bottom of the tank resulting from tank waste thermal conditions. The MW process waste is not conducive to pitting and SCC and there appears to be very little contribution from tank design and construction temperatures. Some or all of the factors can act serially or together to contribute to tank liner failure. 
RPP-RPT-54915, Rev. 0

\section{APPENDIX A1}

TANK U-104 NON-BOILING WASTE OPERATIONAL HISTORY

A1-1 
RPP-RPT-54915, Rev. 0

Table A1-1. ARH-R-43 Waste Tank Leak Experience Table

\begin{tabular}{|c|c|c|c|c|c|c|c|c|c|c|}
\hline $\begin{array}{l}\text { TABLE } 3 \\
\text { Tank } \\
\end{array}$ & $\begin{array}{l}\text { - lnderg } \\
\text { Built }\end{array}$ & $\begin{array}{l}\text { Grourd } \\
\text { First } \\
\text { Uscd }\end{array}$ & $\begin{array}{l}\text { azte Storage Fank Lea? E: } \\
\text { Type of kaste Stored }\end{array}$ & Fertenese & $\begin{array}{l}\text { Leak First } \\
\text { Suspected } \\
\end{array}$ & $\begin{array}{l}\text { Reason for } \\
\text { Suspicion }\end{array}$ & $\begin{array}{cc}\text { Leak Confirmed } & \text { B } \\
\text { by } & \text { F } \\
\end{array}$ & $\begin{array}{l}\text { Bulge } \\
\text { Found } \\
\end{array}$ & $\begin{array}{l}\text { Estimated } \\
\text { Volume of } \\
\text { Leak, gal } \\
\end{array}$ & $\begin{array}{l}\text { Associated } \\
\mathrm{Cs} .137, \mathrm{KCi}\end{array}$ \\
\hline $104-U$ & 1943.44 & 1947 & $\begin{array}{l}\text { Bismuth phosphate waste } \\
\text { Uranium recovery waste }\end{array}$ & Nonboiling & 1956 & Bulged 1 iner & $\begin{array}{l}\text { Refill with } \\
\text { water (1961) }\end{array}$ & Yes & $55,000^{*}$ & 0.09 \\
\hline $113-5 x$ & $1953-54$ & 1958 & Redox waste & Botitug & 1958 & Bulged liner & $\begin{array}{l}\text { Refill with salt } \\
\text { solution (1962) }\end{array}$ & Yes & $15,000^{* *}$ & 8 \\
\hline $106-\mathrm{TV}$ & 1951.52 & 1953 & THP waste & Nonboiling & 1959 & $\begin{array}{l}\text { Liquid leve } 1 \\
\text { measurentents }\end{array}$ & $\begin{array}{l}\text { Soil radiation } \\
\text { readings (1959) }\end{array}$ & & 20,000 & 2 \\
\hline $101 \cdot U$ & 1943.44 & 1946 & $\begin{array}{l}\text { Bismuth phosphatc waste } \\
\text { Uranium recovery waste } \\
\text { Redox kaste }\end{array}$ & Nonboiling & 1959 & $\begin{array}{l}\text { Liquid leve } 1 \\
\text { measurements }\end{array}$ & $\begin{array}{l}\text { Liquid leve } 1 \\
\text { measurements }\end{array}$ & & 30,000 & 23 \\
\hline $105=\mathrm{TY}$ & $1951-52$ & $19 \$ 3$ & TBP waste & Nonboiling & 1960 & $\begin{array}{l}\text { 1.iquid leve } 1 \\
\text { measurements }\end{array}$ & $\begin{array}{l}\text { Liquid leve } 1 \\
\text { ineasurements }\end{array}$ & & 35,000 & 4 \\
\hline $108-5 x$ & $1953-54$ & 1955 & Redox waste & Boiling & 1962 & $\begin{array}{l}\text { Soil radi- } \\
\text { ation } \\
\text { readings }\end{array}$ & $\begin{array}{l}\text { Liquid level } \\
\text { measurements }\end{array}$ & Yes & 3,400 & 17 \\
\hline $105 \cdot A$ & $1954-53$ & 1963 & Purex waste & Boiling & 1963 & $\begin{array}{l}\text { Soil radi- } \\
\text { ation } \\
\text { readings }\end{array}$ & $\begin{array}{l}\text { Soil radiation } \\
\text { readings }\end{array}$ & Yes & Sma11 & \\
\hline $107-5 X$ & $1953-54$ & 1956 & Redox waste & Hoiling & 1964 & $\begin{array}{l}\text { Soil radi - } \\
\text { ation } \\
\text { readings }\end{array}$ & $\begin{array}{l}\text { Soil radiation } \\
\text { readings }\end{array}$ & Yes & Smal 1 & \\
\hline $109-\mathrm{Sx}$ & $1953-54$ & 1955 & Redox waste & Boiling & 1965 & $\begin{array}{l}\text { Soil radi= } \\
\text { ation } \\
\text { readings }\end{array}$ & $\begin{array}{l}\text { No further } \\
\text { evidence }\end{array}$ & No & Sma11 & \\
\hline $115-\$ X$ & $1953 \cdot 54$ & 1958 & Redox waste & Boiling & 1965 & $\begin{array}{l}\text { Liquid level } \\
\text { measurements }\end{array}$ & $\begin{array}{l}\text { Soll radiation } \\
\text { readings }\end{array}$ & & $50,000 * \approx \star$ & 40 \\
\hline $112-5 x$ & $1953-54$ & 1956 & Redox wastc & Boilling & 1969 & $\begin{array}{l}\text { I.iquid level } \\
\text { measurements }\end{array}$ & $\begin{array}{l}\text { Soil radiation } \\
\text { rcadings }\end{array}$ & Yes & 30,000 & 45 \\
\hline $\begin{array}{ll}A & c o \\
A a+ & C o\end{array}$ & $\begin{array}{l}\text { ntained } \\
\text { rtained } \\
\text { rtatned }\end{array}$ & 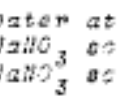 & $\begin{array}{l}\text { tine leath. } \\
\text { lintion at tire of loak. } \\
\text { iution at time of leak. }\end{array}$ & e oos: & uab anger & tantesention. & & & & \\
\hline
\end{tabular}


RPP-RPT-54915, Rev. 0

\section{APPENDIX B1}

TANK U-104 GROSS GAMMA DRYWELL DATA

B1-1 
RPP-RPT-54915, Rev. 0

Table B1-1. Tank U-104 Drywell Radioactivity (K counts per minute) (April 1974 through November 1986) (SD-WM-TI-356)

\begin{tabular}{|c|c|c|c|c|c|c|c|c|c|c|c|c|c|c|c|}
\hline \multicolumn{2}{|c|}{$60-04-03$} & \multicolumn{3}{|c|}{ 60-07-01 } & \multicolumn{3}{|c|}{ 60-07-11 } & \multicolumn{3}{|c|}{ 60-04-08 } & \multicolumn{3}{|c|}{ 60-04-10 } & \multicolumn{2}{|c|}{ 60-04-12 } \\
\hline Date & $\begin{array}{c}\text { Peak } \\
(\mathrm{K} \\
\text { cpm) }\end{array}$ & Date & $\begin{array}{c}\text { Peak } \\
(\mathrm{K} \\
\text { cpm) }\end{array}$ & $\begin{array}{c}\text { Depth } \\
\text { (ft) }\end{array}$ & Date & $\begin{array}{c}\text { Peak } \\
(\mathrm{K} \\
\text { cpm) }\end{array}$ & $\begin{array}{c}\text { Depth } \\
\text { (ft) }\end{array}$ & Date & $\begin{array}{c}\text { Peak } \\
(\mathrm{K} \\
\text { cpm) }\end{array}$ & $\begin{array}{c}\text { Depth } \\
\text { (ft) }\end{array}$ & Date & $\begin{array}{c}\text { Peak } \\
(\mathrm{K} \\
\text { cpm) }\end{array}$ & $\begin{array}{c}\text { Depth } \\
\text { (ft) }\end{array}$ & Date & $\begin{array}{c}\text { Peak } \\
(\mathbf{K} \\
\text { cpm) } \\
\end{array}$ \\
\hline \multicolumn{2}{|c|}{ N/A ${ }^{1}$} & \multicolumn{3}{|c|}{ N/A ${ }^{1}$} & \multicolumn{3}{|c|}{ N/A ${ }^{1}$} & \multicolumn{3}{|c|}{ N/A ${ }^{1}$} & $4 / 18 / 1974$ & 15.6 & 56 & $4 / 18 / 1974$ & $<12$ \\
\hline \multicolumn{2}{|c|}{ N/A ${ }^{1}$} & \multicolumn{3}{|c|}{$\mathrm{N} / \mathrm{A}^{1}$} & $6 / 4 / 1974$ & 73.8 & 50 & $6 / 4 / 1974$ & 70.8 & 53 & $6 / 4 / 1974$ & 13.8 & 53 & $7 / 1 / 1974$ & $<3$ \\
\hline $10 / 4 / 1974$ & $<3$ & \multicolumn{3}{|c|}{$\mathrm{N} / \mathrm{A}^{1}$} & $7 / 18 / 1974$ & 15.2 & 53 & 7/1/1974 & 17.8 & 49 & $6 / 8 / 1974$ & 3.1 & 49 & \multicolumn{2}{|c|}{ N/A ${ }^{1}$} \\
\hline $2 / 11 / 1975$ & $<3$ & \multicolumn{3}{|c|}{$\mathrm{N} / \mathrm{A}^{1}$} & $1 / 24 / 1975$ & 16 & 50 & $2 / 8 / 1975$ & 15.0 & 52 & $1 / 31 / 1975$ & 3.4 & 52 & $1 / 30 / 1975$ & $<3$ \\
\hline 8/6/1975 & $<3$ & \multicolumn{3}{|c|}{ N/A ${ }^{1}$} & 8/6/1975 & 19 & 53 & $8 / 11 / 1975$ & 14.5 & 53 & $8 / 11 / 1975$ & 3.2 & 51 & 8/6/1975 & $<3$ \\
\hline $12 / 30 / 1975$ & $<3$ & \multicolumn{3}{|c|}{ N/A ${ }^{1}$} & \multicolumn{3}{|c|}{ N/A ${ }^{1}$} & $12 / 30 / 1975$ & 13.3 & 52 & $12 / 30 / 1975$ & 2.9 & 53 & $12 / 30 / 1975$ & $<3$ \\
\hline \multicolumn{2}{|c|}{$\mathrm{N} / \mathrm{A}^{1}$} & \multicolumn{3}{|c|}{ N/A ${ }^{1}$} & $1 / 7 / 1976$ & 17 & 53 & \multicolumn{3}{|c|}{ N/A ${ }^{1}$} & \multicolumn{3}{|c|}{ N/A ${ }^{1}$} & \multicolumn{2}{|c|}{ N/A ${ }^{1}$} \\
\hline $5 / 12 / 1976$ & $<3$ & $5 / 12 / 1976$ & 4.0 & 51 & $5 / 5 / 1976$ & 16 & 52 & $5 / 12 / 1976$ & 14.2 & 50 & $5 / 12 / 1976$ & 3.1 & 51 & $5 / 12 / 1976$ & $<3$ \\
\hline \multicolumn{2}{|c|}{ N/A ${ }^{1}$} & $6 / 30 / 1976$ & 3.9 & 53 & $11 / 10 / 1976$ & 17 & 51 & $9 / 1 / 1976$ & 13.7 & 50 & $11 / 28 / 1976$ & 3.5 & 50 & \multicolumn{2}{|c|}{ N/A ${ }^{1}$} \\
\hline \multicolumn{2}{|c|}{ N/A ${ }^{1}$} & $1 / 26 / 1977$ & 3.5 & 53 & \multicolumn{3}{|c|}{ N/A ${ }^{1}$} & $1 / 19 / 1977$ & 13.9 & 51 & \multicolumn{3}{|c|}{$\mathrm{N} / \mathrm{A}^{1}$} & $1 / 5 / 1977$ & $<3$ \\
\hline $\mathrm{N} / \mathrm{A}$ & & $6 / 1 / 1977$ & 4.0 & 53 & $5 / 10 / 1977$ & 17 & 51 & $6 / 1 / 1977$ & 13.4 & 50 & $5 / 18 / 1977$ & 3.2 & 51 & $\mathrm{~N} / \mathrm{A}$ & \\
\hline $11 / 15 / 1977$ & $<3$ & $11 / 22 / 1977$ & 4.5 & 54 & $11 / 22 / 1977$ & 13 & 51 & $11 / 22 / 1977$ & 14.7 & 51 & $11 / 22 / 1977$ & 3.3 & 51 & $11 / 2 / 1977$ & $<3$ \\
\hline N/A & & & $\mathrm{N} / \mathrm{A}^{1}$ & & & & & $2 / 28 / 1978$ & 21.4 & 50 & & J/A ${ }^{1}$ & & $\mathrm{~N} / \mathrm{A}$ & \\
\hline $\mathrm{N} / \mathrm{A}$ & & $5 / 5 / 1978$ & 3.7 & 53 & $5 / 3 / 1978$ & 17 & 50 & $5 / 31 / 1978$ & 31.4 & 50 & $5 / 3 / 1978$ & 3.6 & 50 & $11 / 17 / 1978$ & $<3$ \\
\hline $11 / 16 / 1978$ & $<3$ & $11 / 15 / 1978$ & 3.9 & 54 & $11 / 15 / 1978$ & 18 & 52 & $12 / 1 / 1978$ & 30.5 & 50 & $11 / 17 / 1978$ & 3.8 & 50 & $\mathrm{~N} / \mathrm{A}$ & \\
\hline $\mathrm{N} / \mathrm{A}$ & & & $\mathrm{N}^{\prime} \mathrm{A}^{1}$ & & & & & $6 / 14 / 1979$ & 21.9 & 50 & $8 / 23 / 1979$ & 3.1 & 50 & $\mathrm{~N} / \mathrm{A}$ & \\
\hline $\mathrm{N} / \mathrm{A}$ & & $10 / 31 / 1979$ & 3.6 & 54 & 10/31/1979 & 16 & 52 & $10 / 5 / 1979$ & 19.0 & 51 & & $\mathrm{~J} / \mathrm{A}^{1}$ & & $\mathrm{~N} / \mathrm{A}$ & \\
\hline $11 / 1 / 1979$ & $<3$ & & J/A ${ }^{1}$ & & & & & $11 / 1 / 1979$ & 16.5 & 50 & $11 / 1 / 1979$ & 2.8 & 50 & $11 / 1 / 1979$ & $<3$ \\
\hline $10 / 16 / 1980$ & $<3$ & $11 / 6 / 1980$ & 3.4 & 53 & $11 / 13 / 1980$ & 16 & 53 & $11 / 26 / 1980$ & 17.6 & 51 & $11 / 13 / 1980$ & 3.0 & 50 & $10 / 16 / 1980$ & $<3$ \\
\hline $11 / 19 / 1981$ & $<3$ & $11 / 18 / 1981$ & 3.8 & 53 & $11 / 19 / 1981$ & 14 & 50 & $11 / 11 / 1981$ & 11.6 & 52 & $11 / 11 / 1981$ & 3.5 & 52 & $11 / 19 / 1981$ & $<3$ \\
\hline $10 / 20 / 1982$ & $<3$ & $11 / 3 / 1982$ & 3.2 & 54 & $11 / 3 / 1982$ & 17.2 & 52 & $10 / 20 / 1982$ & 13.6 & 52 & $11 / 3 / 1982$ & 2.9 & 53 & $11 / 3 / 1982$ & $<3$ \\
\hline $6 / 15 / 1983$ & $<3$ & $11 / 22 / 1983$ & 3.7 & 54 & $11 / 22 / 1983$ & 14.9 & 52 & $9 / 21 / 1983$ & 15.0 & 53 & $11 / 16 / 1983$ & 3.3 & 54 & $6 / 15 / 1983$ & $<3$ \\
\hline $6 / 13 / 1984$ & $<3$ & $10 / 25 / 1984$ & 3.7 & 53 & $10 / 25 / 1984$ & 12.3 & 53 & $8 / 22 / 1984$ & 14.6 & 53 & $10 / 17 / 1984$ & 2.9 & 54 & $6 / 13 / 1984$ & $<3$ \\
\hline $6 / 19 / 1985$ & $<3$ & $11 / 20 / 1985$ & 3.5 & 55 & $11 / 20 / 1985$ & 14.4 & 54 & $10 / 15 / 1985$ & 16.2 & 54 & $10 / 30 / 1985$ & $<3$ & $\mathrm{~N} / \mathrm{A}^{1}$ & $6 / 19 / 1985$ & $<3$ \\
\hline $6 / 10 / 1986$ & $<3$ & $11 / 6 / 1986$ & 4.0 & 54 & $11 / 6 / 1986$ & 14.6 & 54 & 9/17/1986 & 16.0 & 54 & $11 / 12 / 1986$ & 3.1 & 55 & $6 / 10 / 1986$ & $<3$ \\
\hline
\end{tabular}




\subsection{TANK 241-U-110 SEGMENT}

\section{TABLE OF CONTENTS}

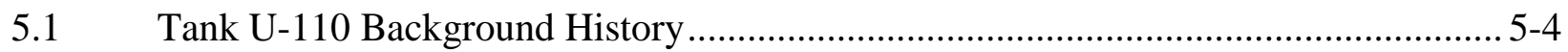

5.2 Tank U-110 Operations Summary ……………................................................ 5-5

5.3 Tank Design/Construction ……………….......................................................... 5-7

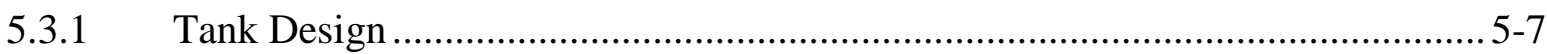

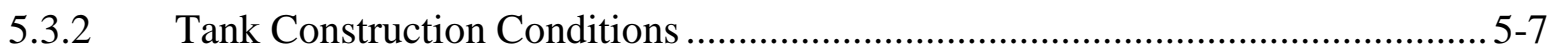

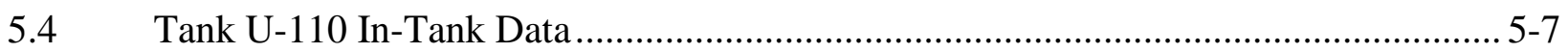

5.4.1 Liquid Level.......................................................................................... 5-7

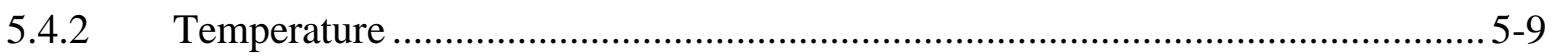

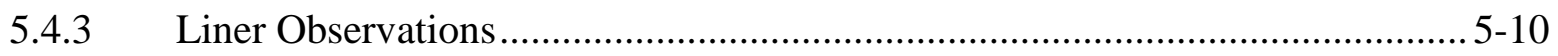

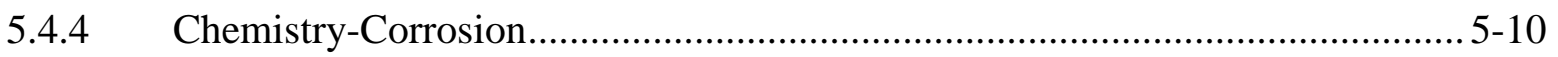

5.4.5 Photographs.......................................................................................... 5-11

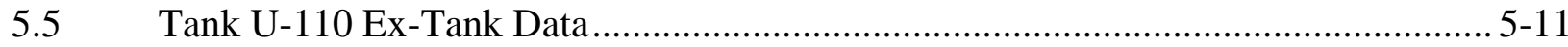

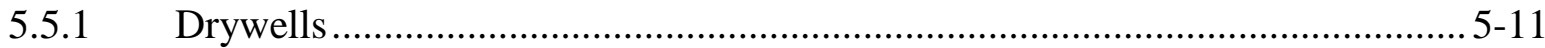

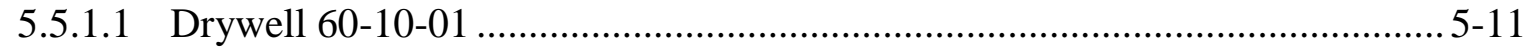

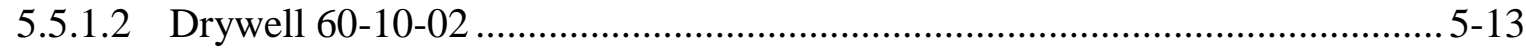

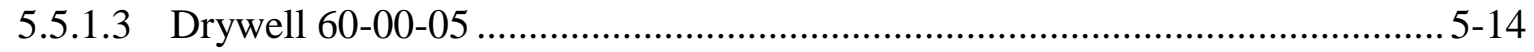

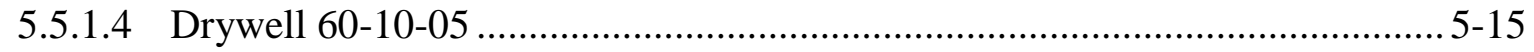

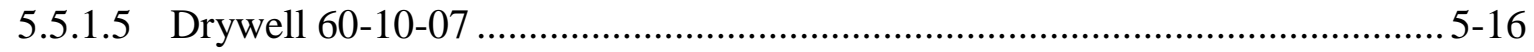

5.5.1.6 Drywell 60-11-03 …………....................................................... 5-19

5.5.1.7 Drywell 60-10-11 …………........................................................ 5-20

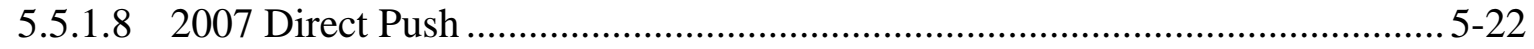

5.5.1.9 Drywell Summary ……………………………................................. 5-24

5.6 Possible Tank U-110 Liner Leak Location(s) ..................................................... 5-24

5.6.1 Leak Detected in 1974-1975 ................................................................... 5-24

5.7 Possible Tank U-110 Liner Leak Cause(s) …………………………................... 5-26

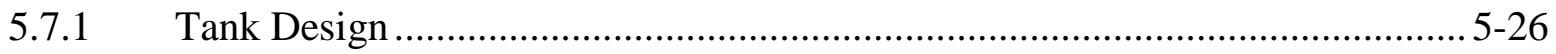

5.7.2 Thermal Conditions ………………………........................................... 5-26

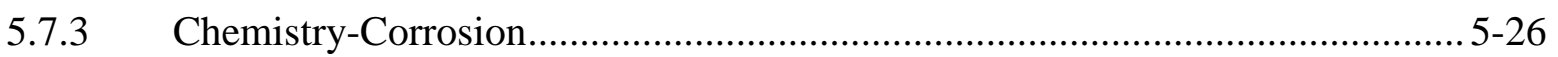




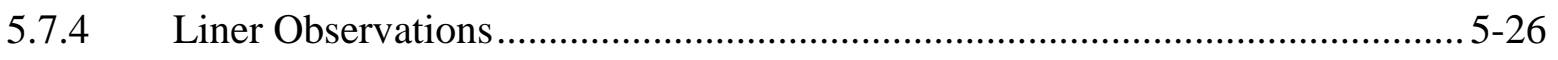

5.7.5 Tank Construction Temperature ……………........................................... 5-26

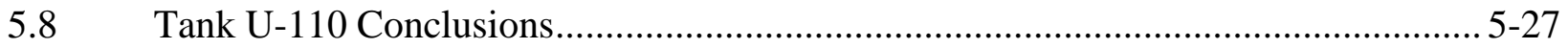

\section{Appendices}

Appendix A2 Tank U-110 Gross Gamma Drywell Data........................................................ A2-1

\section{LIST OF FIGURES}

Figure 5-1. Tank U-110 Associated Drywells ……………………….............................. 5-4

Figure 5-2. Operational Leak History of Tank U-110 ……................................................... 5-6

Figure 5-3. Tank U-110 End of Quarter Surface Level ............................................................ 5-8

Figure 5-4. Tank U-110 Liquid Level March 25, 1975 to July 9, 1975 .................................... 5-9

Figure 5-5. Tank U-110 Drywell 60-10-01 (RPP-7729) ……………………….................... 5-12

Figure 5-6. Tank U-110 Drywell 60-10-02 (RPP-7729) …………………………………... 5-13

Figure 5-7. Tank U-110 Drywell 60-00-05 (RPP-7729) ………………………………...... 5-14

Figure 5-8. Tank U-110 Drywell 60-10-05 (RPP-7729) …………………………………... 5-15

Figure 5-9. Tank U-110 Drywell 60-10-07 NaI Probe (RPP-7729) .......................................... 5-16

Figure 5-10. Tank U-110 Drywell Red GM Probe (RPP-7729) ………………………......... 5-17

Figure 5-11. Tank U-110 Drywell Red GM Probe (RPP-7729) ............................................... 5-17

Figure 5-12. Tank U-110 Drywell 60-10-07 Green GM Probe (RPP-7729) ............................ 5-18

Figure 5-13. Tank U-110 Drywell 60-10-07 Green GM Probe (RPP-7729) ............................. 5-18

Figure 5-14. Tank U-110 Drywell 60-11-03 (RPP-7729) …………………………………... 5-20

Figure 5-15. Tank U-110 Drywell 60-10-11 (RPP-7729) ………………………………...... 5-21

Figure 5-16. Gamma and Moisture Log for C5607 (RPP-36007) ………………………….... 5-23

Figure 5-17. Tank U-110 Possible Leak Location (1974-1975) .............................................. 5-25 


\section{RPP-RPT-54915, Rev. 0}

\section{LIST OF TABLES}

Table 5-1. Tank U-110 Waste Storage Chronology ............................................................ 5-10

Table 5-2. Waste Chemistries for Waste Types Stored in Tank U-110................................5-10

Table A2-1. Tank U-110 Drywell Radioactivity (K counts per minute) (August 1973 through September 1986)................................................................... A2-2 


\subsection{TANK U-110 BACKGROUND HISTORY}

This section provides information on the historical waste loss event associated with Single-Shell Tank (SST) 241-U-110 (U-110). There are seven drywells located around tank U-110 with specified distances from the drywell to the tank footing shown in Figure 5-1: 60-00-05 installed in 1944, 60-11-03 installed in 1973, 60-10-01, 60-10-05, 60-10-07, installed in 1974, and 60-1011 and 60-10-02, installed in 1976. One nearby direct push was installed in 2007.

The bottom of the tank footing is $\sim 39$-ft 1-in Below Grade Surface (BGS) with 7.2-ft soil cover over the dome (WHC-SD-WM-TI-665).

\section{Figure 5-1. Tank U-110 Associated Drywells}

Tank inner ring is steel liner; outer ring is outer edge of tank footing

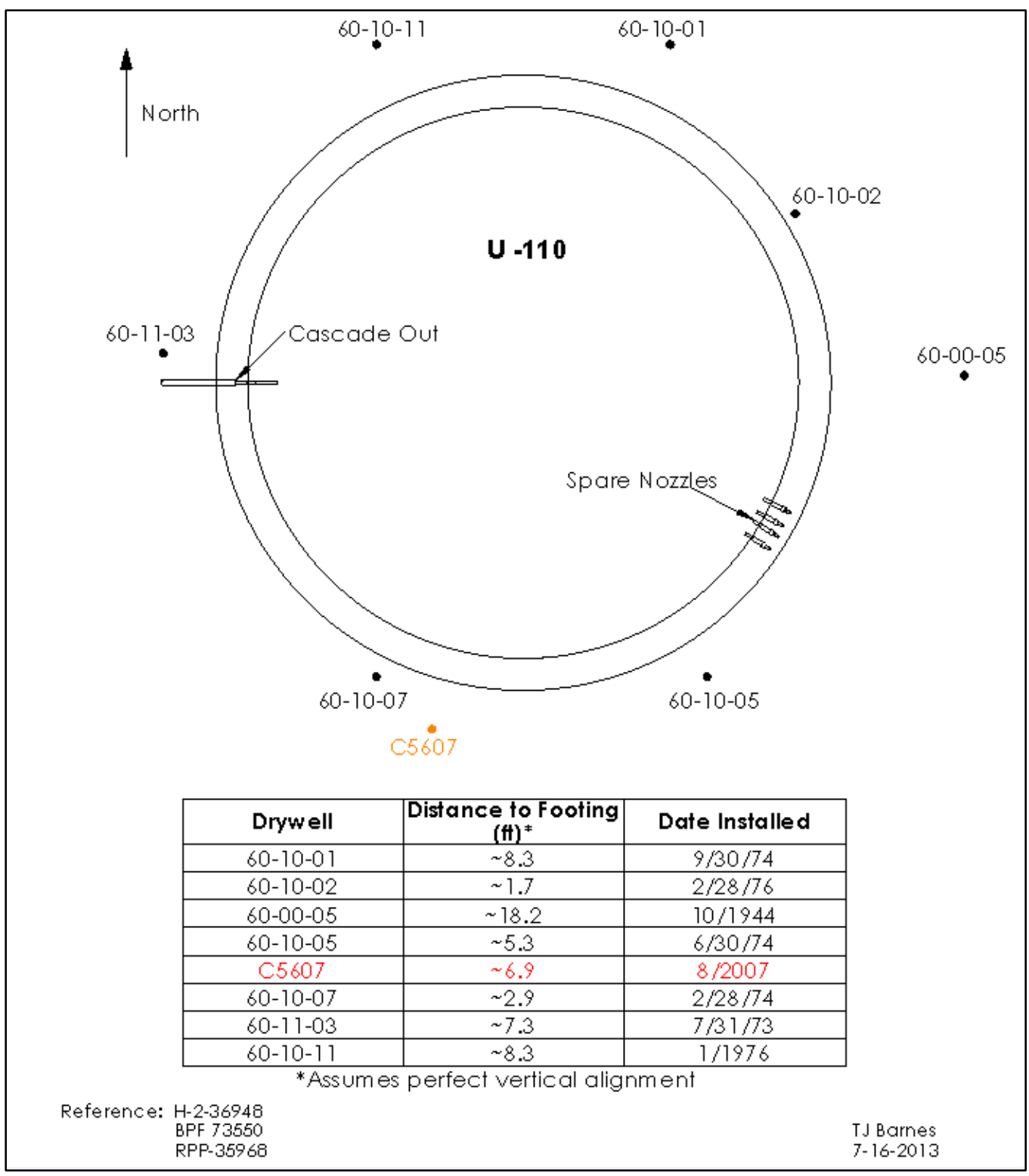




\subsection{TANK U-110 OPERATIONS SUMMARY}

Tank U-110 first began receiving 221-T Plant (T Plant) first cycle waste (1C) typically neutralized with coating waste (CW) on July 22, 1946 (HW-7-4542-DEL, Hanford Engineer Works Monthly Report July 1946). The tank was declared full and 1C waste began to cascade to tank U-111 after April 1947 (HW-7-6184-DEL, Hanford Works Monthly Report April 1947). First cycle waste cascaded into tank U-111 and tank U-112 through May 1948 when the three tank cascade was declared full (HW-10166-DEL, Hanford Works Monthly Report May 1948) and no other transfers occurred through July 1951. No record of tank transfers was available between August 1951 and March 1952. Beginning in April 1952, supernatant was pumped out of tank U-110 to the sludge level leaving a volume reported at $336 \mathrm{kgal}$ (HW-27838, Waste Status Summary Period: April, May, and June 1952). No waste transactions were reported until January 1954.

Beginning on January 13, 1954, tank U-110 started receiving REDOX concentrated salt waste (HW-30851, Waste Status Summary January 1954). The REDOX waste level decreased through self-evaporation from June 1954 through August 1955. Beginning in September 1955 through July 1957, periodic transfers of REDOX coating waste occurred into and out of tank U-110. No other transfers occurred until July 1958 when $39 \mathrm{kgal}$ of water was added to the tank. No waste transfers into or out of the tank occurred from August 1958 until the second quarter in 1969.

The next waste transfer occurred in June 1969 when $157 \mathrm{kgal}$ of supernatant was transferred to tank TX-118. The solids content was subsequently adjusted downward 47 -in to $284 \mathrm{kgal}$. No additional transfers were made until the third quarter of 1972 through the second quarter of 1975 when tank U-110 periodically received a total of $316 \mathrm{kgal}$ of waste from 222-S Laboratory.

Tank U-110 was first reported to be leaking on July 9, 1975 after a 0.5 -in liquid level decrease was observed. The 0.5-in liquid level decrease was reported between May 24, 1975 to June 26, 1975 (OR 75-67, Liquid Level Decrease in Tank 110-U). Beginning on July 9, 1975, $225 \mathrm{kgal}$ supernatant was transferred out of tank U-110 to tank U-111 leaving approximately $161 \mathrm{kgal}$ of sludge (ARH-CD-336C, Production and Waste Management Division Waste Status Summary July 1, 1975 through September 30, 1975).

Tank U-110 was declared administratively interim stabilized in December 1984 with $16 \mathrm{kgal}$ of drainable liquid remaining (HNF-EP-0182). The estimated leak volume ranges from 5 to 8.1 kgal.

The operational history of tank U-110 leak related details including liquid level is charted in Figure 5-2. 
RPP-RPT-54915, Rev. 0

Figure 5-2. Operational Leak History of Tank U-110

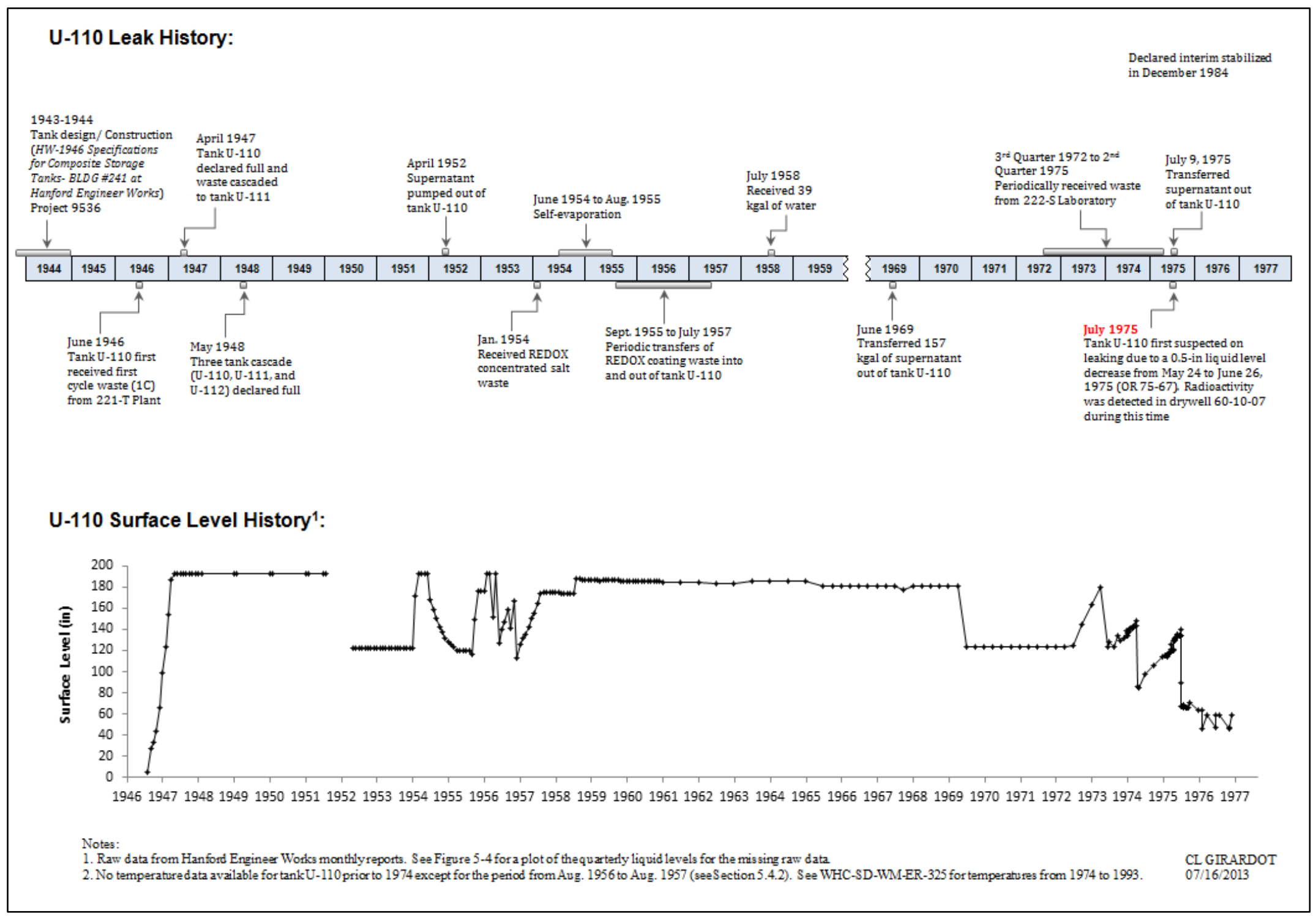


RPP-RPT-54915, Rev. 0

\subsection{TANK DESIGN/CONSTRUCTION}

\subsubsection{Tank Design}

The steel bottoms of the U Farm tanks intersect the sidewall on a 4-ft radius knuckle transition (BPF-73550, Drawings D-2 and D-3). The rounded knuckle transition, the three-ply asphaltic membrane waterproofing between the liner and the concrete, a notched footing construction joint, and the concrete shell are features common to all U Farm tanks (see Section 3.1.1).

\subsubsection{Tank Construction Conditions}

The U Farm tanks were constructed between February 1944 and October 1944. Temperatures are not available for 1944 between May 18 and December 1. From the start of U Farm tank construction through May 18, 1944 there were two minimum temperatures of $12^{\circ} \mathrm{F}$ with daytime temperatures of $44^{\circ} \mathrm{F}$ and $57^{\circ} \mathrm{F}$, one at $18^{\circ} \mathrm{F}$, and four at $20^{\circ} \mathrm{F}$ with day time temperatures between $41^{\circ} \mathrm{F}$ and $56^{\circ} \mathrm{F}$.

As described in Section 3.1.2, cold weather affects the ductile-to-brittle steel transition temperature, with $18^{\circ} \mathrm{F}$ being the assumed design temperature for the carbon steel liner, which could result in a fracture upon impact. However, in general, the temperatures during the U Farm construction time frame were much milder than those experienced during 241-SX Farm construction where ductile-to-brittle steel transition temperatures were exceeded.

Design, fabrication, and erection of the tank steel lining were required to be in accordance with current "Standards Specifications for Elevated Steel Water Tanks, Standpipes and Reservoirs" as promulgated by the "American Water Works Association" (BPF 73550). Welding requirements were required to conform to the American Welding Society's "Code for Arc and Gas Welding in Building Construction", Section 4.

\subsection{TANK U-110 IN-TANK DATA}

\subsubsection{Liquid Level}

The liquid level plot in Figure 5-3 indicates the transfer activity into and out of tank U-110. The liquid levels are end of quarter levels so this figure may not reflect all transfers into and out of

the tank that occurred during the operational history. See Figure 5-2 for historical monthly liquid level readings. 
Figure 5-3. Tank U-110 End of Quarter Surface Level

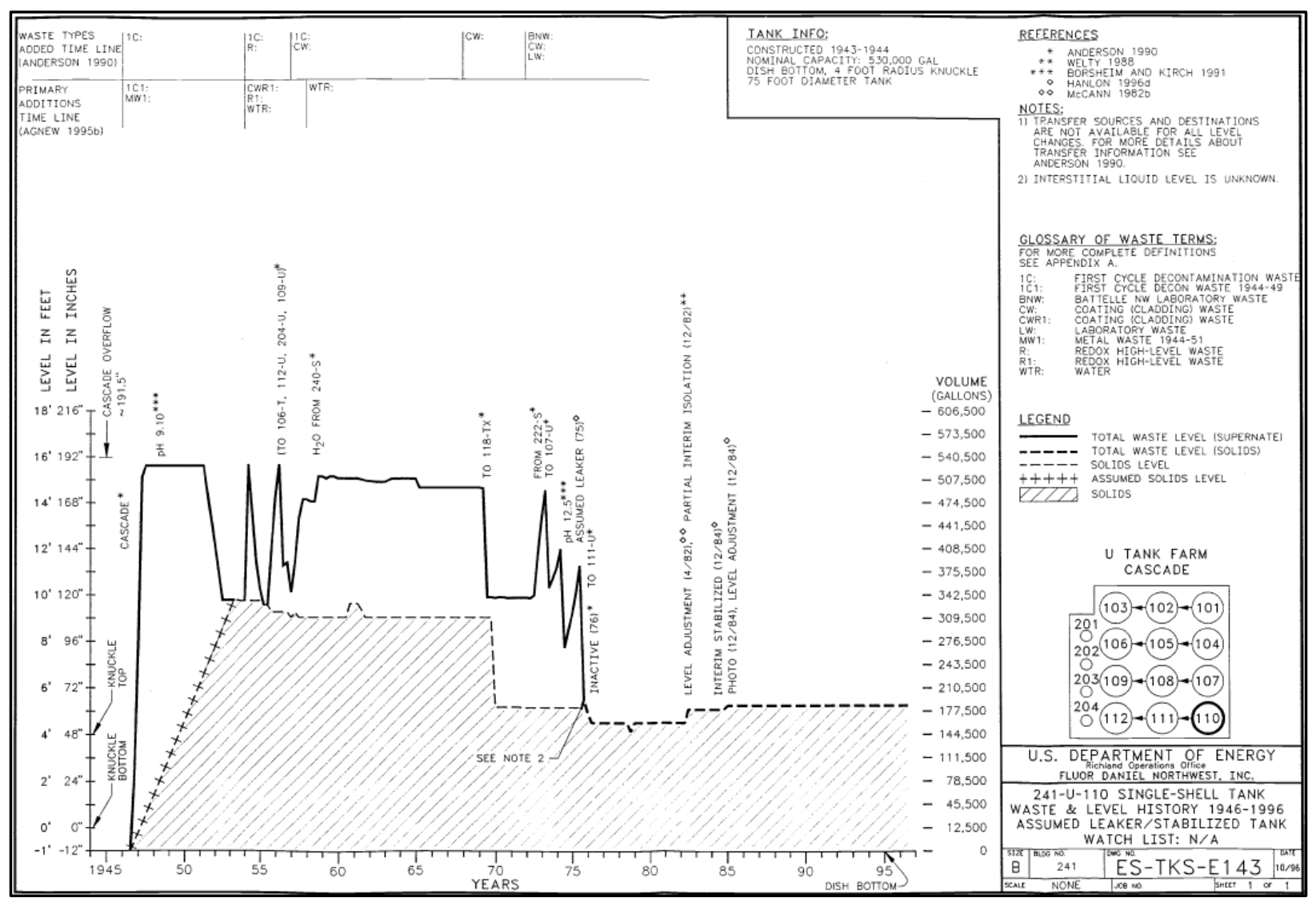

WHC-SD-WM-ER-325, Rev. 0, 1994, Supporting Document for the SW Quadrant Historical Tank Content Estimate for U-Tank Farm.

Tank U-110 was first suspected of leaking due to a 0.5 -in liquid level decrease that was reported between May 24, 1975 and June 26, 1975 (OR 75-67). The last transfer before this unexplained liquid level decrease occurred in the second quarter of 1975 and a total of $39 \mathrm{kgal}$ was transferred to tank U-110 (ARH-CD-336B, Production and Waste Management Division Waste Status Summary April 1, 1975 through June 30, 1975). The liquid level was reported to be 134.7-in on May 24, 1975 and down to 134.2-in by June 26 (see Figure 5-4). Psychometric data taken June 11, 1975, gave no assistance in explaining the liquid level drop. Photographs taken on June 26, 1975, were reported to give no additional information on the cause of the liquid level drop.

The liquid level then appeared to stabilize through July 4, 1975. On July 8, 1975, the liquid level dropped an additional 0.1-in. During this time, radioactivity in drywell 60-10-07 was also increasing. Tank U-110 was classified as a leaker on July 9, 1975 (OR 75-67). By July 19, 1975, a salt well pump was in operation but apparently was not functioning properly.

Photographs indicated the pump suction was hung up on an island of sludge with a considerable volume of liquid still evident. Thus, on July 28, 1975 a well casing and pump were installed in the center riser. Photographs taken August 5 and September 12, 1975 reported successful removal of the surface pools of liquid. 
RPP-RPT-54915, Rev. 0

Figure 5-4. Tank U-110 Liquid Level March 25, 1975 to July 9, 1975

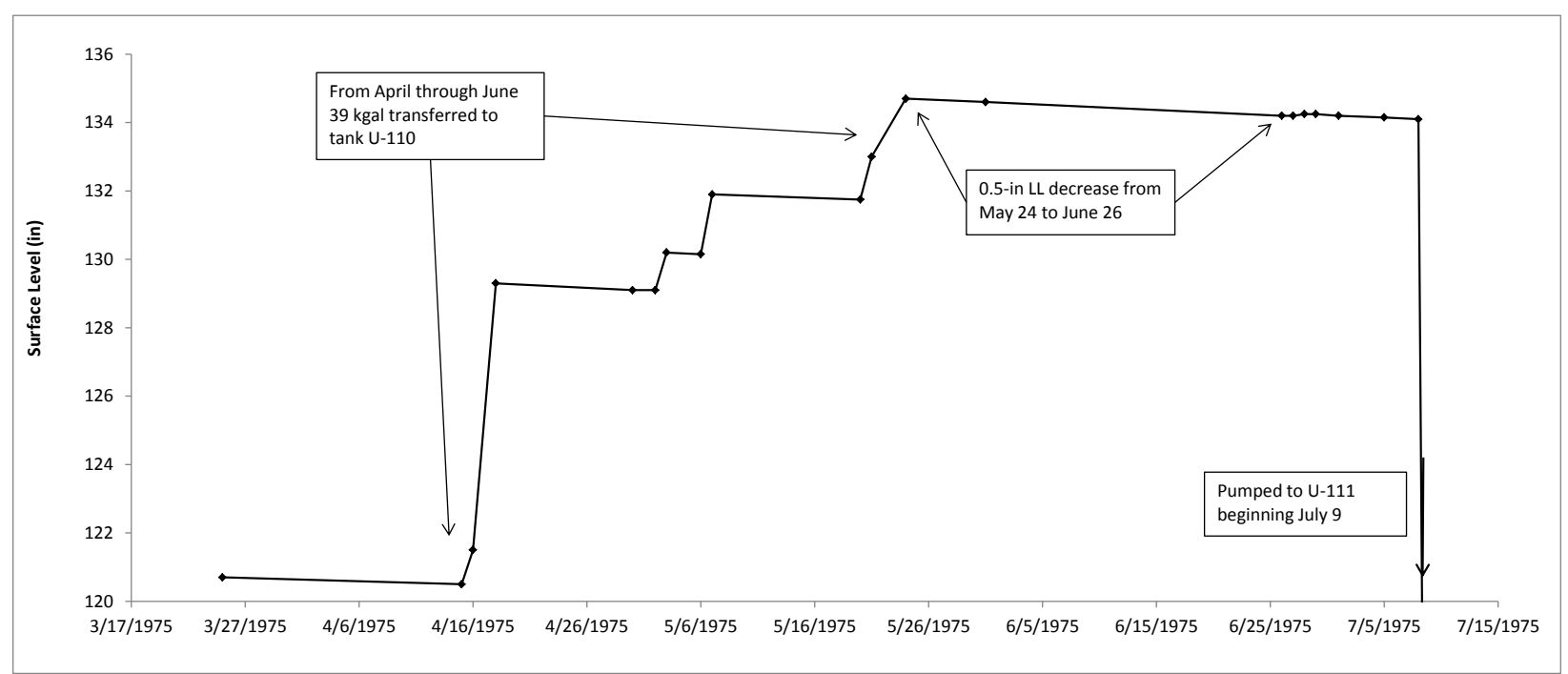

\subsubsection{Temperature}

Seven tanks in the B, C, T, and U Farms that contained metal waste (MW) ranged in temperature from $84^{\circ} \mathrm{F}$ to $174^{\circ} \mathrm{F}$ between 1945 and 1947 (HW-14946). The only U Farm tank (tank U-101) contained MW waste which was found to range from $84^{\circ} \mathrm{F}$ to $138^{\circ} \mathrm{F}$ between 1945 and 1947 (HW-14946). Document HW-20742, Loss of Depleted Metal Waste Supernatant to Soil, reports MW was cascaded into a 241-BX Farm series of tanks with temperatures recorded in the first tank of $\sim 180^{\circ} \mathrm{F}$, which contains the bulk of the uranium and fission products, and $\sim 70^{\circ} \mathrm{F}$ in the last tank of the cascade. The MW contains approximately $90 \%$ of the fission products from the Bismuth Phosphate $\left(\mathrm{BiPO}_{4}\right)$ process at both 221-U Plant and 221-B Plant. Tank U-110, the first tank in the tank U-110 through tank U-112 cascade, which contained a mixture of $1 \mathrm{C} / \mathrm{CW}$ waste, would have experienced much lower temperatures as the fission product content was much lower than MW. The $1 \mathrm{C} / \mathrm{CW}$ waste contained approximately $10 \%$ of the $\mathrm{BiPO}_{4}$ process fission products with approximately $90 \%$ in the MW.

No temperature data were recovered for tank U-110 from May 1946 when the tank was first put into service until 1974 except for a one year period from August 1956 to August 1957. Sludge temperature plots for the one year period between August 1956 and August 1957 (RHO-CD1172 ) indicated a gradual decreasing temperature from $\sim 140^{\circ} \mathrm{F}$ to $\sim 115^{\circ} \mathrm{F}$. These temperatures were during a period of REDOX coating waste transfers into the tank after the storage of REDOX concentrated salt waste. There had been a gradual decrease in liquid level during storage of REDOX concentrated salt waste indicating the temperature may have been higher at that time as the liquid level decrease had been attributed to evaporation.

Tank U-110 waste temperatures from 1974 to 1993 which ranged from $\sim 105^{\circ} \mathrm{F}$ to $65^{\circ} \mathrm{F}$ can be found in WHC-SD-WM-ER-325. REDOX coating waste supernatant was transferred out of tank U-110 in 1969 and laboratory waste was transferred into the tank from 1972 until it was pumped in 1975 . 


\subsubsection{Liner Observations}

No liner observations relating to a tank U-110 leak have been found.

\subsubsection{Chemistry-Corrosion}

Tank U-110 began receiving waste in July 1946 and received various waste types throughout operation as shown in Table 5-1. The typical concentration for nitrite, nitrate, and hydroxide for waste is shown in Table 5-2. Nitrite and hydroxide are known as nitrate induced SCC inhibitors. One key characteristic for inhibiting SCC is to maintain a high nitrite concentration to nitrate concentration ratio (see Section 3.2.4).

Table 5-1. Tank U-110 Waste Storage Chronology

\begin{tabular}{|c|c|c|}
\hline Date & Waste Type & Length of Storage \\
\hline July 1946 to December 1953 & 1C/CW & $\sim 7$ years \\
\hline January 1954 to August 1955 & R & $\sim 1.5$ years \\
\hline September 1955 to June 1972 & CW & $\sim 3$ years \\
\hline July 1972 to September 1975 & LW & $\sim 3$ years \\
\hline
\end{tabular}

Table 5-2. Waste Chemistries for Waste Types Stored in Tank U-110

\begin{tabular}{|c|c|c|c|c|}
\hline Waste Type & {$\left[\mathrm{NO}_{3}{ }^{-}\right]$} & {$\left[\mathrm{NO}_{2}{ }^{-}\right]$} & {$\left[\mathrm{OH}^{-}\right]$} & $\begin{array}{c}\text { Meets Current } \\
\text { DST Specification }\end{array}$ \\
\hline $1 \mathrm{C}^{1}$ & 1.54 & 0.26 & 0.28 & $\mathrm{No}^{3}$ \\
\hline $\mathrm{CW}^{1}$ & 0.6 & 0.9 & 1.0 & $\mathrm{Yes}^{5}$ \\
\hline $\mathrm{R}^{4}$ & 4.83 & \multicolumn{4}{|c|}{0.74} & $\mathrm{No}^{5}$ \\
\hline $\mathrm{LW}$ & \multicolumn{4}{|c|}{ Unknown $^{6}$} \\
\hline
\end{tabular}

1. Reference WHC-EP-0449, 1991, The Sort on Radioactive Waste Type Model: A Method to Sort Single-Shell Tanks into Characteristic Groups.

2. Reference OSD-T-151-00007, Rev. 12, 2013, Operating Specification for the Double-Shell Storage Tanks.

3. Waste type $1 \mathrm{C}$ does not meet the current DST specification for waste chemistry; however, 1C was mixed with CW prior to adding to the tank. Depending on this ratio, the resulting waste may have met the DST specification.

4. Reference WHC-EP-0772, 1994, Characterization of the Corrosion Behavior of the Carbon Steel Liner in Hanford Site Single Shell Tanks.

5. Does not meet the current DST specification since the hydroxide and nitrite concentrations are not greater than or equal to $1.2 \mathrm{M}$.

6. The chemical content of the total of $316 \mathrm{kgal}$ of laboratory waste transferred to tank U-110 has not been found.

Tank U-110 stored REDOX concentrated salt waste for $\sim 1.5$ years. REDOX concentrated salt waste could be a concern for either pitting or SCC under the tank U-110 conditions especially at elevated temperatures that were high enough to cause evaporation of the waste.

The chemical content of the 222-S laboratory waste (LW) could not be recovered and normally would be diluted; however, the quantity of $361 \mathrm{kgal}$ that tank U-110 was reported to have received over three years leads to some uncertainty as one would not expect that much LW over three years. 
RPP-RPT-54915, Rev. 0

The other waste types stored in tank U-110 should not have resulted in pitting or SCC. The waste type $1 \mathrm{C} / \mathrm{CW}$ was combination of the acidic $1 \mathrm{C}$ waste from $\mathrm{T}$ Plant neutralized with the basic $\mathrm{CW}$ waste in T Plant. The combination would have resulted in a $\left[\mathrm{NO}_{3}{ }^{-}\right] /\left(\left[\mathrm{OH}^{-}\right]+\left[\mathrm{NO}_{2}{ }^{-}\right]\right)$ ratio of $<2.5$, OSD-T-151-0007 specification for waste chemistry. The CW waste by itself met the OSD-T-151-0007 specification for waste chemistry.

\subsubsection{Photographs}

Photographs of tank U-110 taken before and after pumping the tank in 1975 were reviewed and no anomalies were indicated that relate to a liner failure.

\subsection{TANK U-110 EX-TANK DATA}

\subsubsection{Drywells}

There are seven drywells located around tank U-110: 60-00-05 installed in 1944, 60-11-03 installed in 1973, 60-10-01, 60-10-05, 60-10-07, installed in 1974, and 60-10-11 and 60-10-02, installed in 1976. One nearby direct push was installed in 2007. All of the radiation readings in drywells are assumed to be maximum or peak readings unless otherwise noted (see Section 3.3.2). The following subsections report the available drywell information and the drywell summary section provides the analyses of the associated drywells with tank U-110.

\subsubsection{Drywell 60-10-01}

In August 1996, drywell 60-10-01 is located approximately 12.5-ft from the north-northeast side of tank U-110. Drywell 60-10-01 was drilled in 1974 with the first recoverable reading on September 27, 1974 reported as a less than value (see Appendix A2). Readings continued to be reported as less than values through September 1986.

Cs-137 was detected continuously from ground surface to a depth of about 28-ft BGS and intermittently at greater depths (GJ-HAN-39, Vadose Zone Characterization Project at the Hanford Tank Farms Tank Summary Data Report for Tank U-110). Indications of Cs-137 were noted at 33-ft, 35-ft, from 40.5 to $41-\mathrm{ft}, 78-\mathrm{ft}$ BGS, and at the bottom of the drywell. The Cs-137 concentrations in the continuous zone ranged between 0.2 and about $9 \mathrm{pCi} / \mathrm{g}$. The maximum Cs137 concentration of about $9 \mathrm{pCi} / \mathrm{g}$ was measured at a depth of $6.5-\mathrm{ft}$ BGS; a concentration of approximately $6 \mathrm{pCi} / \mathrm{g}$ was observed at a depth of 1.5-ft BGS. Document GJ-HAN-39 reports, "These two zones of Cs-137 contamination most likely resulted from a surface or near-surface spill from piping or transfer lines that migrated downward."

Since historical radioactivity in this drywell is very low, and the GJ-HAN-39 report indicated low levels of radioactivity below the surface level, drywell 60-10-01 is not being included as part of the leak location for tank U-110. Figure 5-5 shows the depths of radioactivity from 1975 to 1995 (RPP-7729). 
RPP-RPT-54915, Rev. 0

Figure 5-5. Tank U-110 Drywell 60-10-01 (RPP-7729)

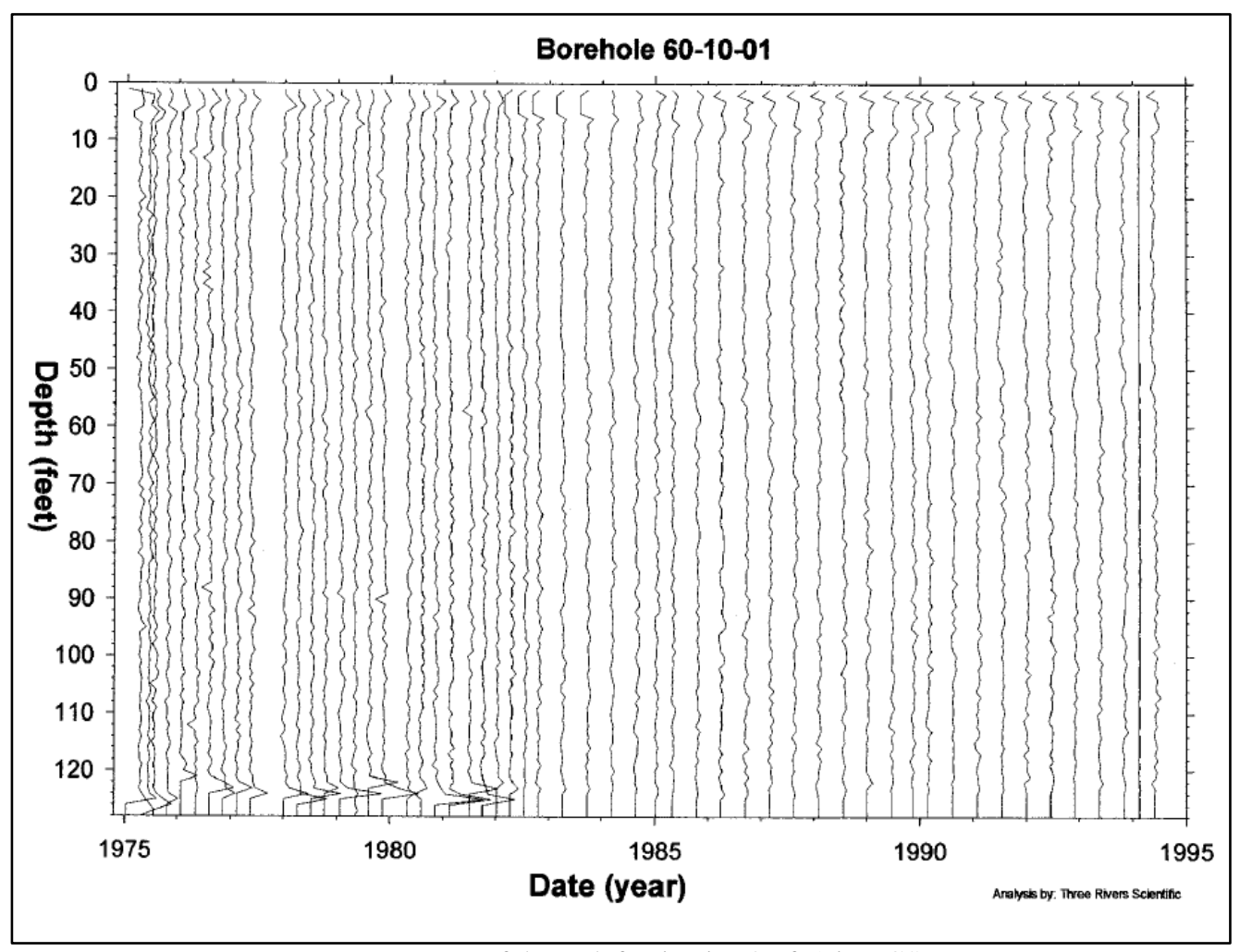

Note: Bottom of the tank footing is 39 -ft 1-in BGS 


\subsubsection{Drywell 60-10-02}

Drywell 60-10-02 is located approximately 5-ft from the northeast side of tank U-110. Drywell 60-10-02 was drilled in 1976 with the first recoverable reading on May 12, 1976 reported as a less than value (see Appendix A2). Readings continued to be reported as less than values through September 1986.

In August 1996, Cs-137 was detected from ground surface to a depth of 9-ft, at 10.5-ft, and 13-ft BGS. Concentrations of Cs-137 ranged between 0.2 and $4 \mathrm{pCi} / \mathrm{g}$ (GJ-HAN-39). The highest contamination levels $(3.72 \mathrm{pCi} / \mathrm{g})$ were observed at a depth of 1.5-ft BGS. Cs-137 contamination of approximately $3 \mathrm{pCi} / \mathrm{g}$ was observed at a depth of 7.5-ft BGS. The near-surface contamination probably resulted from the migration of a surface or near-surface spill or leak. Some of the contamination may have migrated down the casing to a depth of 13-ft BGS. Document GJ-HAN-39 reports, "No Cs-137 contamination was observed below the 13-ft depth."

Since historical radioactivity in this drywell is very low, and GJ-HAN-39 report indicated low levels of radioactivity, drywell 60-10-02 is not being included as part of the leak location for tank U-110. Figure 5-6 shows the depths of radioactivity from 1975 to 1995 (RPP-7729).

Figure 5-6. Tank U-110 Drywell 60-10-02 (RPP-7729)

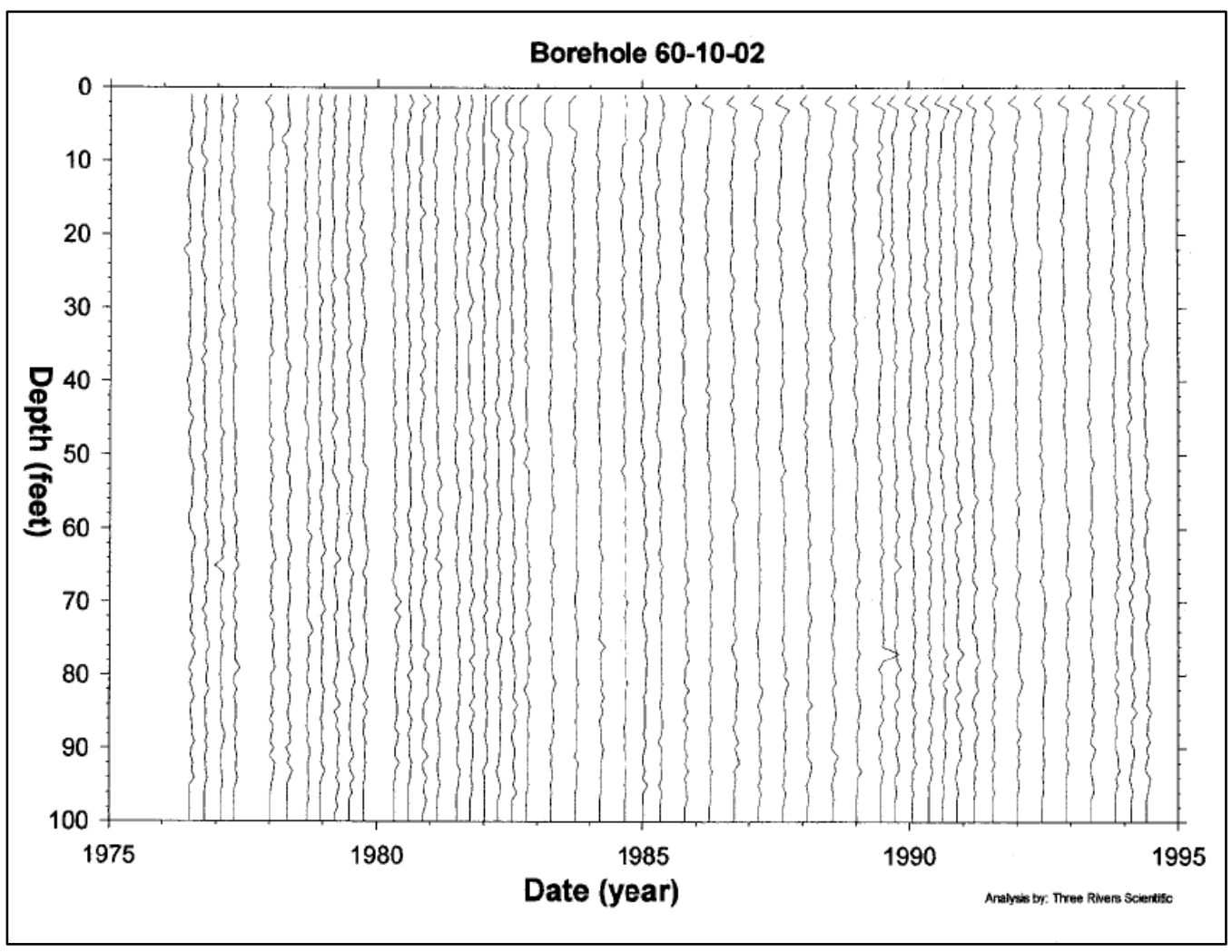

Note: Bottom of the tank footing is 39-ft 1-in BGS 


\subsubsection{Drywell 60-00-05}

Drywell 60-00-05 is located approximately 23-ft from the east side of tank U-110. Drywell 6000-05 was drilled in 1944 with the first recoverable readings reported on August 23, 1973 as a less than value (see Appendix A2). Readings continued to be reported as less than values through September 1986.

In August 1996, contamination in the form of Cs-137 was detected in this drywell continuously from near the ground surface to a depth of 16.5-ft BGS and intermittently throughout the length of the drywell. Indications of Cs-137 contamination were observed in the depth intervals between 49 and 50-ft, 53 and 62-ft, 68 and 69-ft, at 76, 77, 83, 92, 99, 111, 117, 120.5-ft BGS, and at the bottom of the drywell (GJ-HAN-39). Concentrations ranged between 0.2 and slightly more than $6 \mathrm{pCi} / \mathrm{g}$. Document GJ-HAN-39 reports, "The near-surface Cs-137 contamination apparently migrated from a spill or leak site to the drywell position on the surface or within the upper layer of the soil. The contamination observed below the 49-ft depth may have originated from the surface, traveled along the outer casing, entered the inner casing through the perforations, and from there migrated along the inner casing to the various locations where it has been observed."

Since historical radioactivity in this drywell is very low, and the GJ-HAN-39 report indicated low levels of radioactivity below the surface level, drywell 60-00-05 is not being included as part of the leak location for tank U-110. Figure 5-7 shows the depths of radioactivity from 1975 to 1995 (RPP-7729).

Figure 5-7. Tank U-110 Drywell 60-00-05 (RPP-7729)

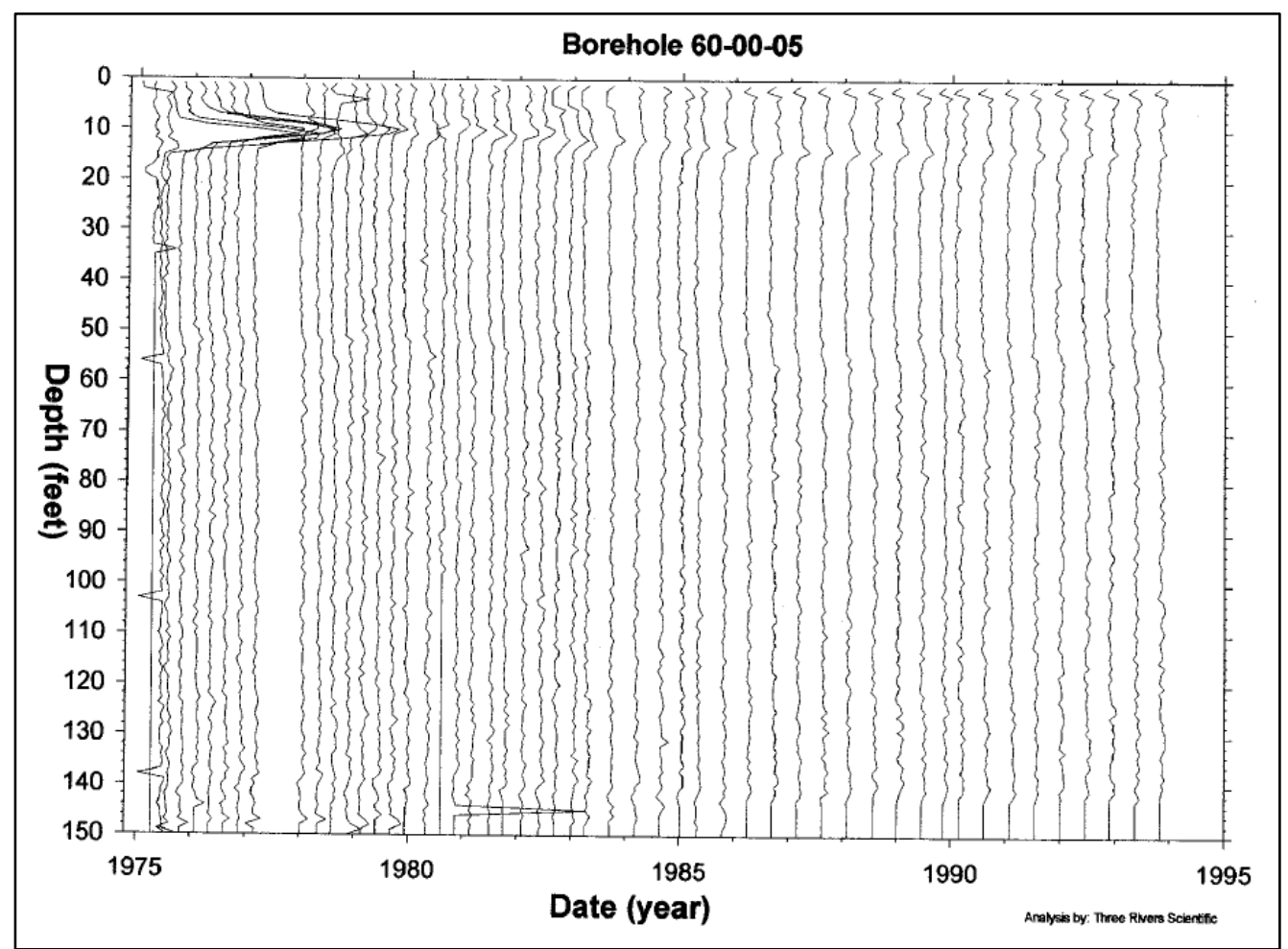

Note: Bottom of the tank footing is $\sim 39$-ft 1-in BGS 


\subsubsection{Drywell 60-10-05}

Drywell 60-10-05 is located approximately 9-ft from the southeast side of tank U-110. Drywell 60-10-05 was drilled in 1974 with the first recoverable reading on July 19, 1974 reported as a less than value (see Appendix A2). Readings continued to be reported as less than values through September 1986.

In August 1996, Cs-137 was detected intermittently in this drywell (GJ-HAN-39). It was observed from the ground surface to a depth of about 6-ft, between 11 and 16-ft, from 20 to 26-ft BGS, and at the bottom of the drywell. The Cs-137 concentrations in the three zones noted within the upper 25-ft of the drywell ranged between 0.2 and about $6 \mathrm{pCi} / \mathrm{g}$. The highest concentration $(5.6 \mathrm{pCi} / \mathrm{g})$ was measured at a depth of 12.5-ft BGS. In addition, Cs-137 contamination of about $5 \mathrm{pCi} / \mathrm{g}$ was observed at the mouth of the drywell.

Historical radioactivity in this drywell is very low, and the GJ-HAN-39 report indicated low levels of radioactivity, drywell 60-10-05 is therefore not being included as part of the leak location for tank U-110. Figure 5-8 shows the depths of radioactivity from 1975 to 1995 (RPP7729).

Figure 5-8. Tank U-110 Drywell 60-10-05 (RPP-7729)

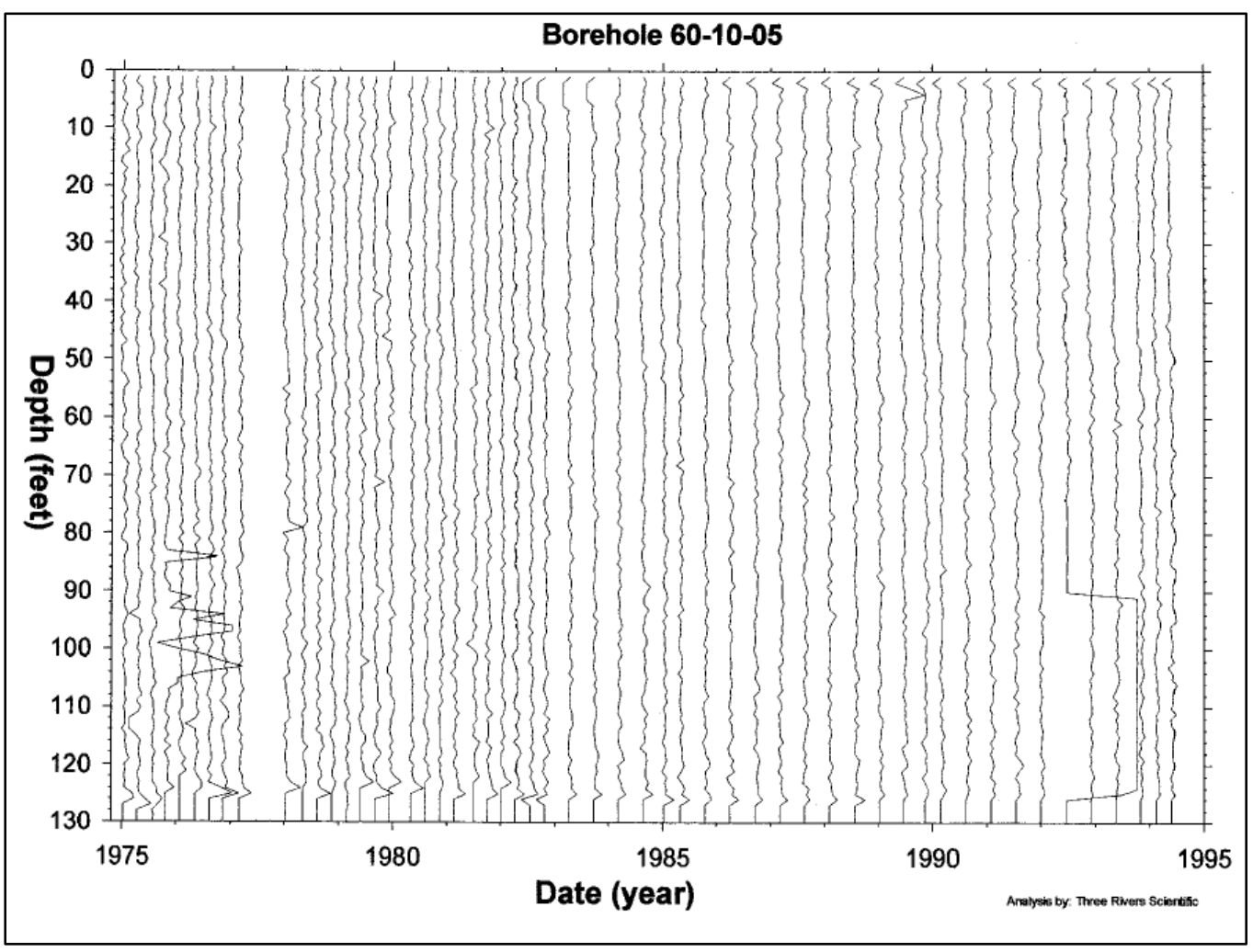

Note: Bottom of the tank footing is $\sim 39$-ft 1-in BGS 


\subsubsection{Drywell 60-10-07}

Drywell 60-10-07 is located approximately 7-ft from the south southwest side of tank U-110. Drywell 60-10-07 was drilled on 1974 with the first recoverable reading on April 12, 1974 with a peak of $6.96 \mathrm{~K} \mathrm{cpm}$ at 33 -ft BGS (see Appendix A2). The early measurements were made immediately following completion of the drywell and indicate that the contamination at this depth occurred before the detected liquid level decrease in 1975. In June 1975 radioactivity began to be detected at $\sim 53-\mathrm{ft}$ BGS and peaked near this level with increasing radioactivity even after pumping the tank.

Drywell 60-10-07 was examined with the Green-GM probe (01), Red-GM probe (02), and the NaI probe (04) to monitor the large Cs-137 gamma variations in this drywell (see Figure 5-9, Figure 5-10, and Figure 5-12). The NaI probe is the most sensitive and was able to obtain data until about 1980 when the probe became saturated with high levels of radioactivity, making the data unreliable. The NaI probe shows the early influx of radioactivity. There is some conflict in the variability of the grade thickness product, used to eliminate variable sampling effects for a given zone, between the Green-GM probe, Figure 5-13, and the less sensitive Red probe, Figure 5-11. However, both the Green-GM probe and the Red probe indicate radioactivity Cs-137 below 50-ft BGS.

Figure 5-9. Tank U-110 Drywell 60-10-07 NaI Probe (RPP-7729)

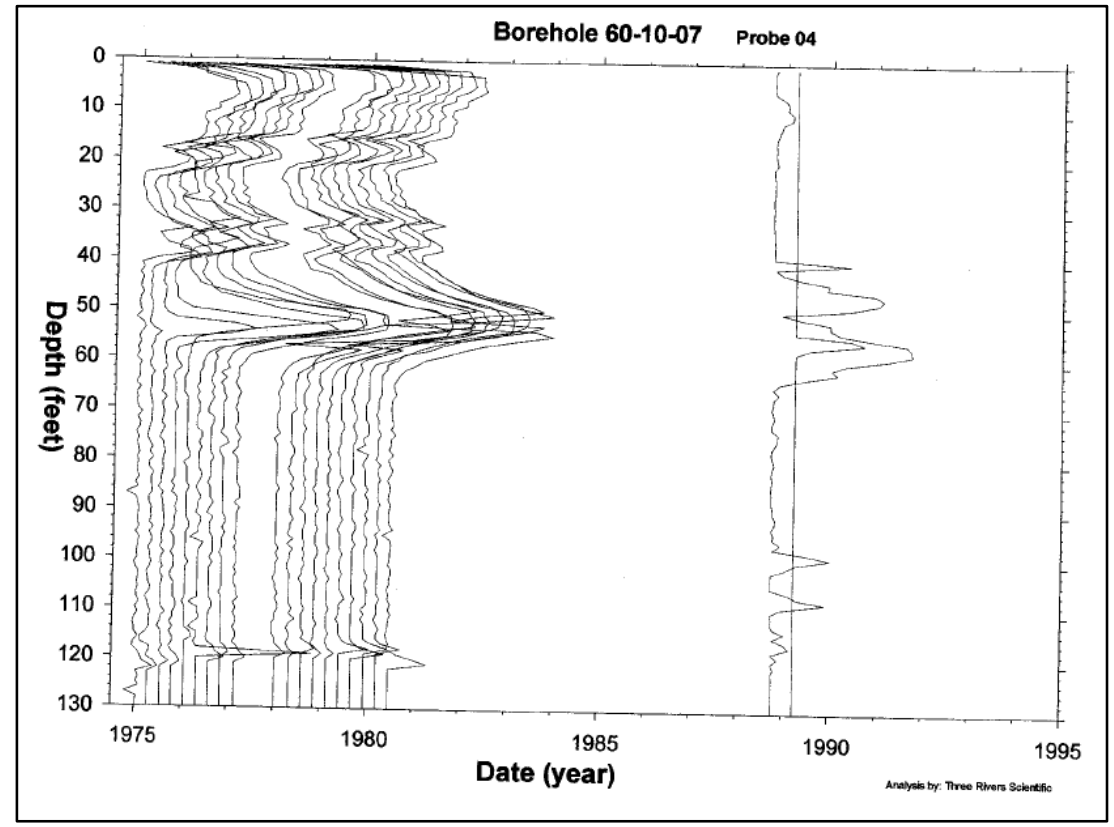

Note: Bottom of the tank footing is $\sim 39$-ft 1-in BGS 
RPP-RPT-54915, Rev. 0

Figure 5-10. Tank U-110 Drywell Red GM Probe (RPP-7729)

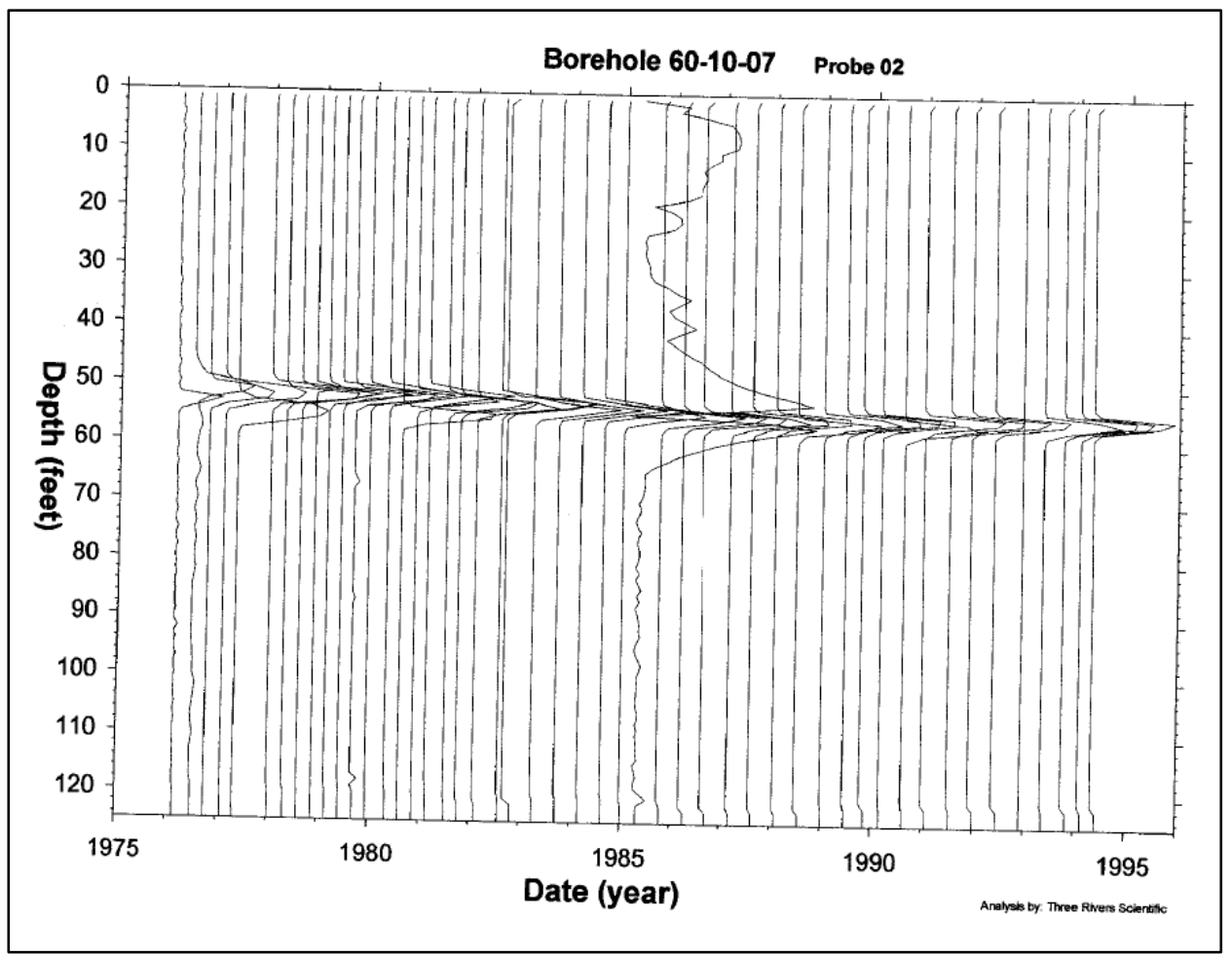

Note: Bottom of the tank footing is $\sim 39$-ft 1 -in BGS

Figure 5-11. Tank U-110 Drywell Red GM Probe (RPP-7729) Grade Thickness Product

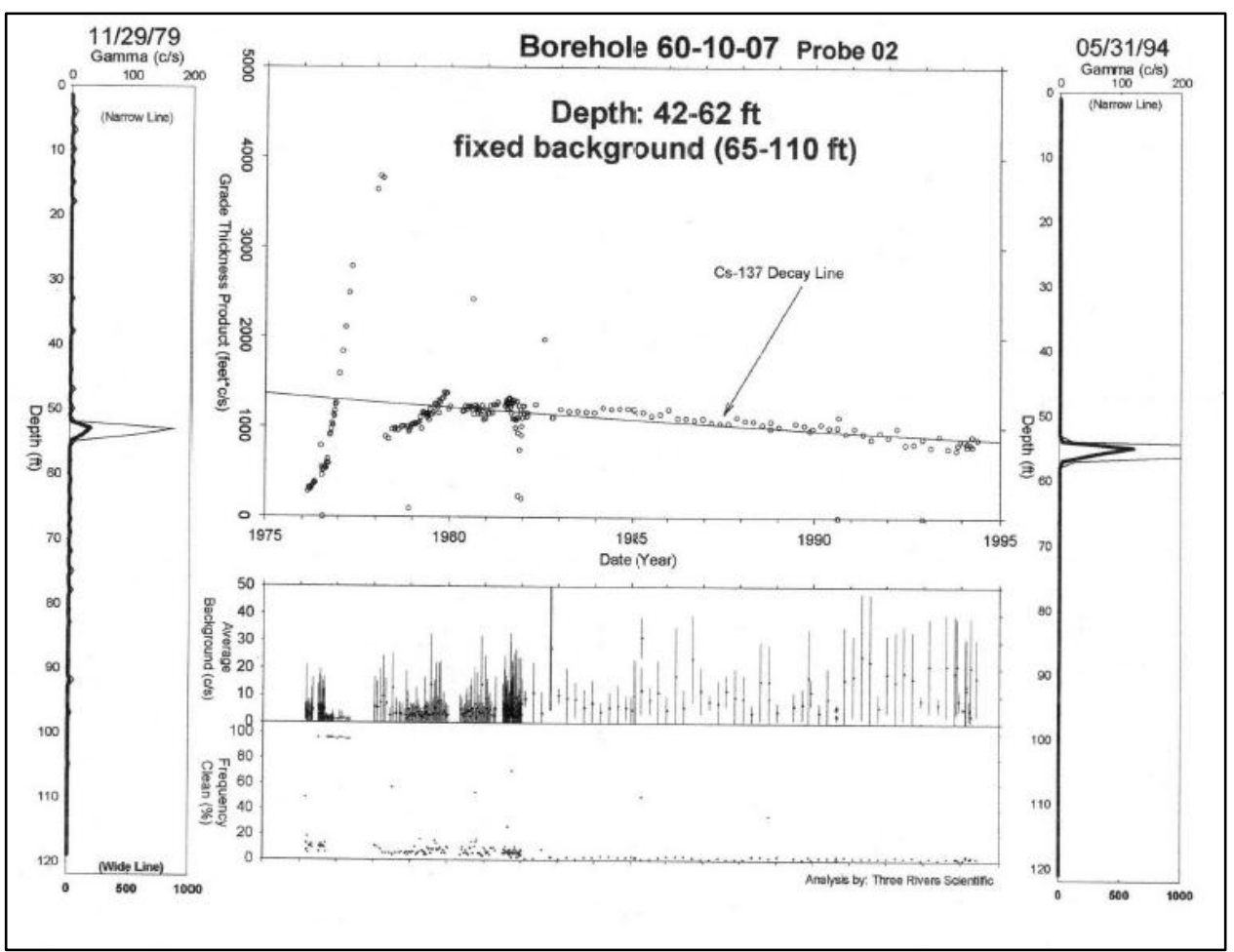

Note: Bottom of the tank footing is $\sim 39$-ft 1 -in BGS 
RPP-RPT-54915, Rev. 0

Figure 5-12. Tank U-110 Drywell 60-10-07 Green GM Probe (RPP-7729)

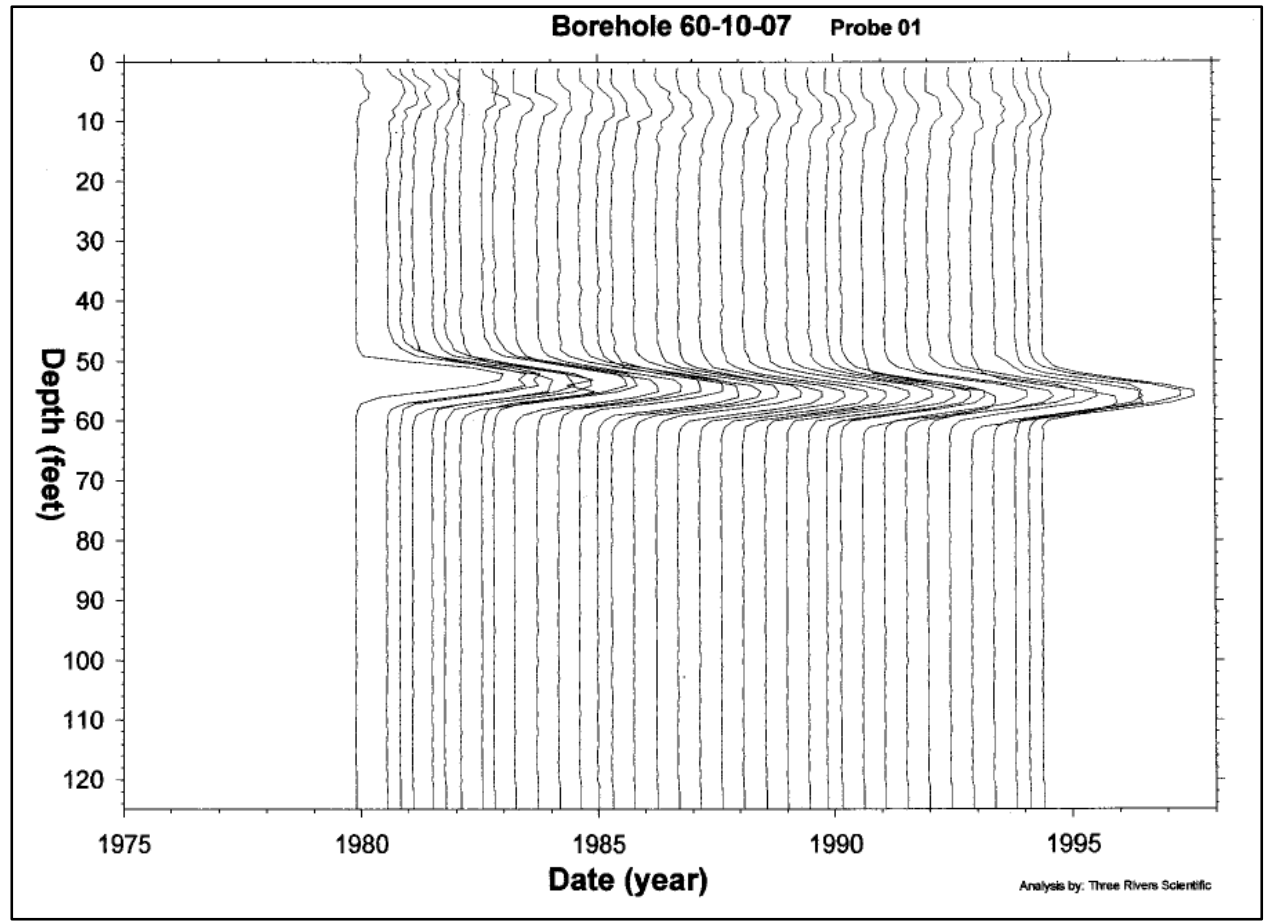

Note: Bottom of the tank footing is $\sim 39$-ft 1-in BGS

Figure 5-13. Tank U-110 Drywell 60-10-07 Green GM Probe (RPP-7729) Grade thickness Product

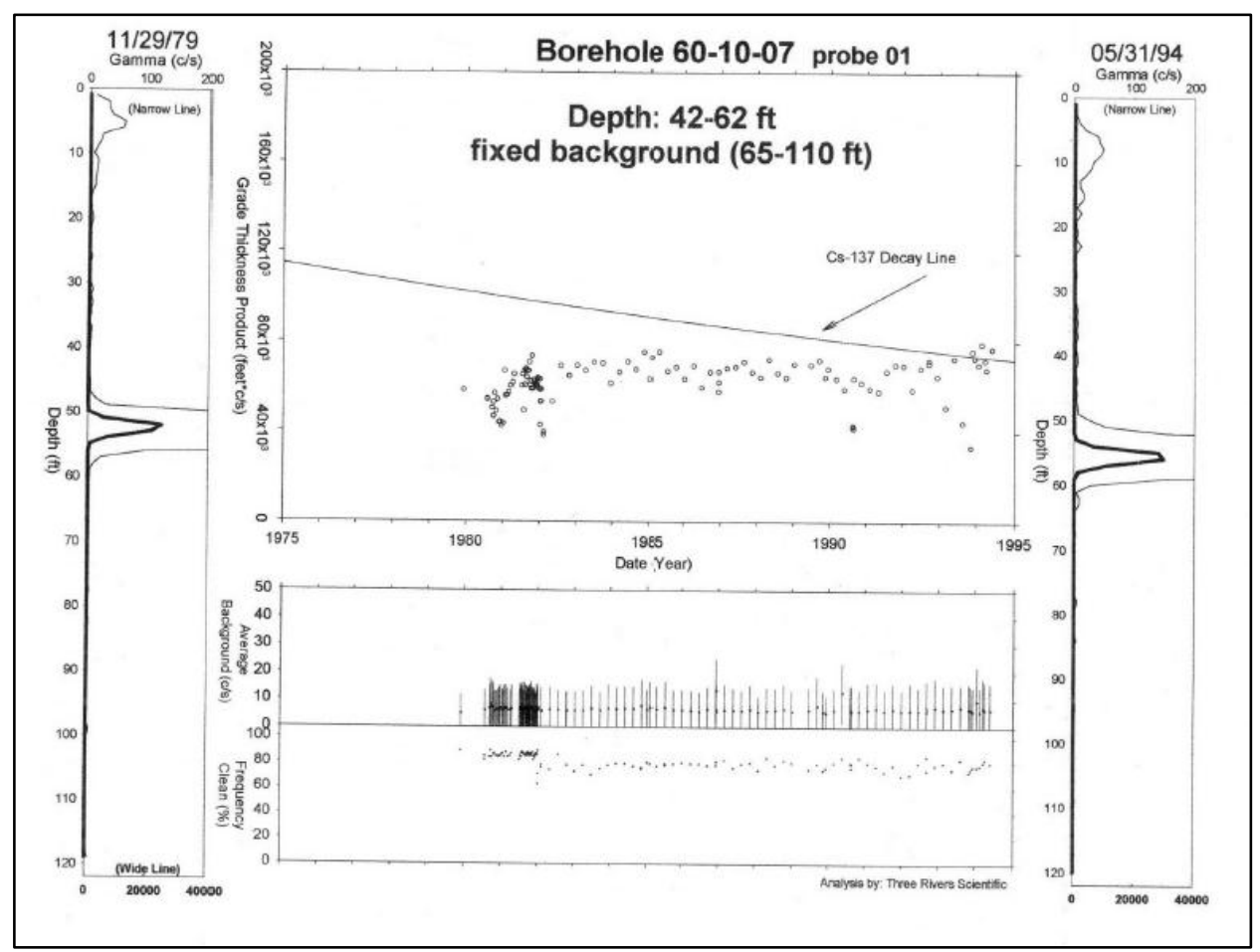

Note: Bottom of the tank footing is 39-ft 1-in BGS 
In August 1996, significant Cs-137 contamination was observed in this drywell continuously from the ground surface to a depth of 64.5-ft BGS and intermittently at greater depths to bottom of the drywell (GJ-HAN-39). The Cs-137 concentrations in the upper 9-ft of the drywell ranged up to $655 \mathrm{pCi} / \mathrm{g}$. Even higher concentrations of Cs-137 projected to be above $1,000 \mathrm{pCi} / \mathrm{g}$ were indicated at depths between 52 and 59-ft BGS; the highest measured concentration in this region of the drywell was $462 \mathrm{pCi} / \mathrm{g}$. However, because of high dead time, the SGLS system could not record the data in this region of the drywell (total gamma count rate greater than 500,000 cps).

\subsubsection{Drywell 60-11-03}

Drywell 60-11-03 is located approximately 12-ft west of tank U-110. Drywell 60-11-03 was drilled in 1973 with the first recoverable reading on September 21, 1973 reported as a less than value (see Appendix A2). Readings continued to be reported as less than values through June 1986.

In August 1996, significant Cs-137 contamination was detected in this borehole near the ground surface (GJ-HAN-39). The zone of contamination extends from the surface to a depth of 11-ft BGS. Concentrations of Cs-137 in this interval ranged between 0.7 and $525 \mathrm{pCi} / \mathrm{g}$. Detectable Cs-137 contamination (between 0.2 and $1.0 \mathrm{pCi} / \mathrm{g}$ ) was noted between depths of 16.5 and $21.5-\mathrm{ft}$ BGS and at the bottom of the drywell. Detectable quantities of Co-60 (approximately $11 \mathrm{pCi} / \mathrm{g}$ ) and Eu-154 (approximately $100 \mathrm{pCi} / \mathrm{g}$ ) were also noted in the near-surface zone where the Cs137 contamination occurs. Document GJ-HAN-39 reports, "The near-surface contamination is probably contained within a transfer line or its concrete encasement."

Since historical radioactivity in this drywell is very low, and the GJ-HAN-39 report indicated low levels of radioactivity below the surface level, drywell 60-11-03 is not being included as part of the leak location for tank U-110. Figure 5-14 shows the depths of radioactivity from 1975 to 1995 (RPP-7729). 
Figure 5-14. Tank U-110 Drywell 60-11-03 (RPP-7729)

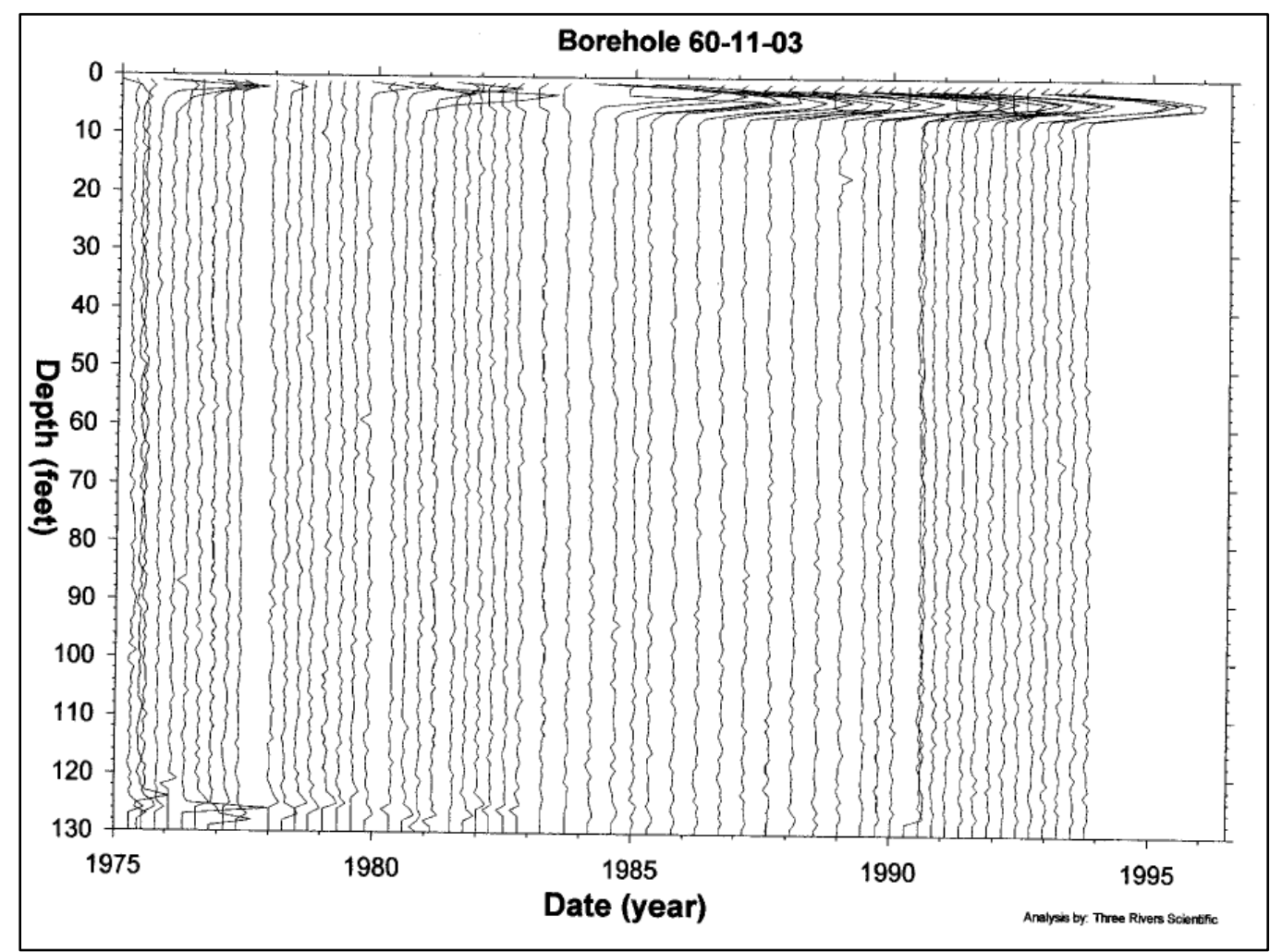

Note: Bottom of the tank footing is $\sim 39$-ft 1-in BGS

\subsubsection{Drywell 60-10-11}

Drywell 60-10-11 is located approximately 12 -ft north northwest of tank U-110. Drywell 60-1011 was drilled in 1976 with the first recoverable reading on May 12, 1976 reported as a less than value (see Appendix A2). Readings continued to be reported as less than values through June 1986.

In August 1996, Cs-137 was observed from the ground surface to a depth of about 14.5-ft, at 23$\mathrm{ft} \mathrm{BGS}$, and at the bottom of the drywell (GJ-HAN-39). The Cs-137 concentrations in the nearsurface zones ranged between 0.2 and slightly less than $6 \mathrm{pCi} / \mathrm{g}$. The highest concentration of $5.91 \mathrm{pCi} / \mathrm{g}$ was measured at a depth of $1.5-\mathrm{ft}$ BGS.

Since historical radioactivity in this drywell is very low, and the GJ-HAN-39 report indicated low levels of radioactivity below the surface level, drywell 60-10-11 is not being included as part of the leak location for tank U-110. Figure 5-15 shows the depths of radioactivity from 1975 to 1995 (RPP-7729). 
RPP-RPT-54915, Rev. 0

Figure 5-15. Tank U-110 Drywell 60-10-11 (RPP-7729)

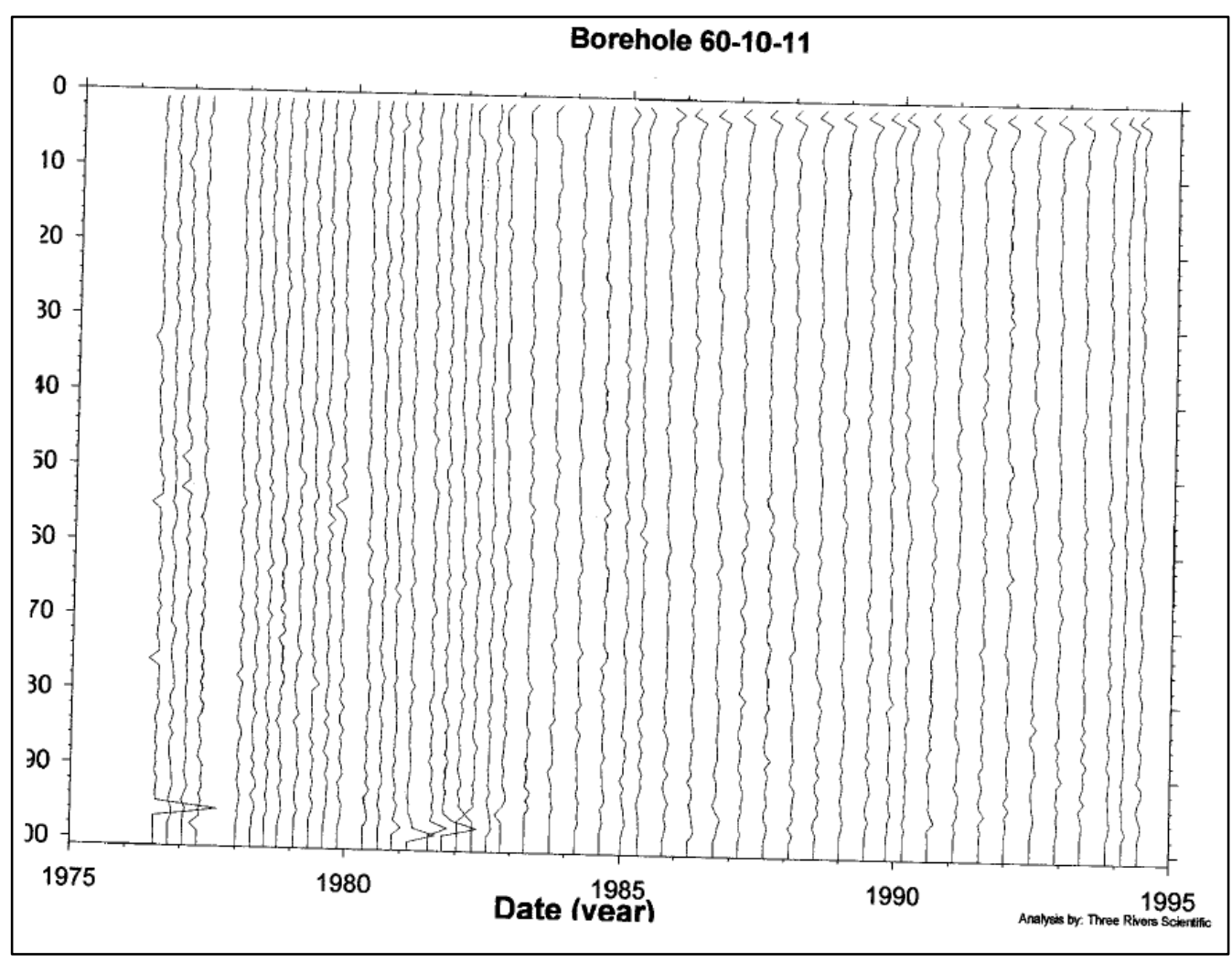

Note: Bottom of the tank footing is $\sim 39$-ft 1-in BGS 


\subsubsection{2007 Direct Push}

In 2007, one direct push (C5607) was installed near tank U-110 for spectral gamma logging (see Figure 5-16). The C5607 direct push, located about 14-ft from drywell 60-10-07, was logged for moisture and gamma properties (RPP-36007). A peak Cs-137 activity of 9,950 pCi/g was found at about the same 55-ft BGS depth as drywell 60-10-07.

The gross gamma survey data for the Gross Gamma and Moisture Survey Plot (see Figure 5-16) were dead-time corrected and the results were converted to two calibration units.

1. Equivalent Ra-226 for natural radionuclides (brown line). Hanford sediments have concentrations less than $5 \mathrm{pCi} / \mathrm{g}$ eRa-226. The plot scale for eRa-226 is $0-25 \mathrm{pCi} / \mathrm{g}$ (black scale).

2. Equivalent Cs-137 for contamination zones (orange/yellow line) is shown for concentrations greater than $4 \mathrm{pCi} / \mathrm{g}$ of eCs-137. The plot scale for eCs-137 (orange/yellow line) is displayed a logarithmic scale $\left(10^{0}\right.$ to $\left.10^{5}\right)$.

The green GM is displayed as a green dotted line with the logarithmic eCs-137 pCi/g scale. The neutron moisture survey data are shown as the blue dashed line. The moisture plot scale is 0-25 (\%vf) Cs-137 was identified as the dominant gamma emitting radionuclide, energy (keV) plot insert. 
Figure 5-16. Gamma and Moisture Log for C5607 (RPP-36007)

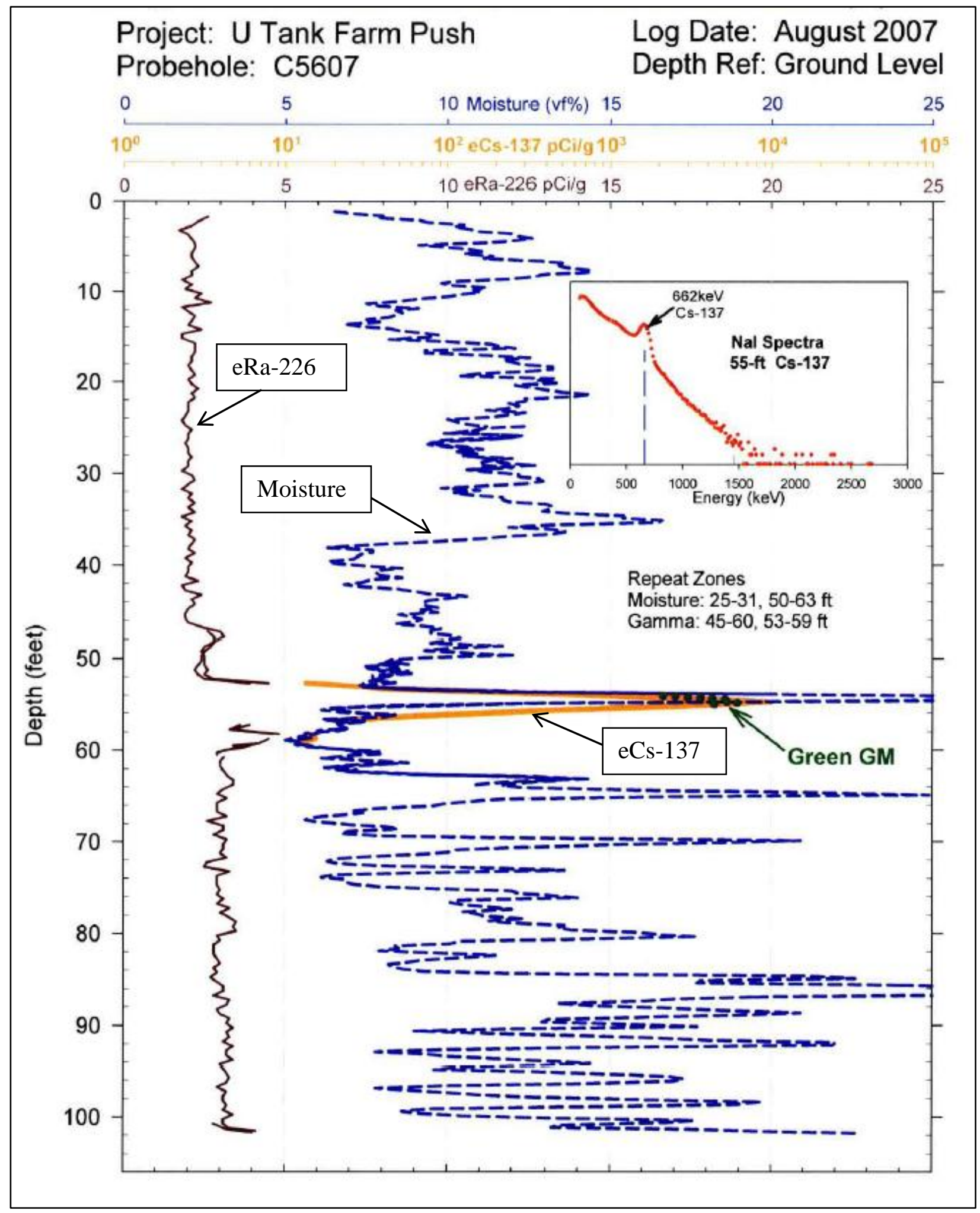




\subsubsection{Drywell Summary}

Tank U-110 was first reported to be leaking on July 9, 1975 after a 0.5-in liquid level decrease was observed. The 0.5-in liquid level decrease was reported between May 24, 1975 to June 26, 1975 (OR 75-67).

Tank U-110 drywells 60-10-01, 60-10-02, 60-10-05, 60-00-05, 60-10-11, and 60-11-03 do not indicate any radioactivity associated with a tank U-110 leak. Therefore, these drywells are not included in the leak location for tank U-110.

Peak radioactivity in drywell 60-10-07 was reported near 34-ft BGS when the well was drilled in April 1974 and increased in intensity spreading to 54-ft BGS in June-July 1975. The increased radioactivity coincided with the 0.5 -in liquid level decrease. Earlier decreases in liquid level may have occurred, but these decreases would have been masked by tank pumping and transfer operations. A direct push (C5607), installed in 2007, reported a peak radioactivity at approximately the same level BGS as drywell 60-10-07.

\subsection{POSSIBLE TANK U-110 LINER LEAK LOCATION(S)}

A liner leak may have penetrated the waterproof membrane at any location or pooled on the waterproof membrane and followed concrete cracks or construction joints to a different location for egress to the soil, including the top of the tank footing.

Tank U-110 had at least one leak site which is likely at or near the bottom of the tank based on liquid level decrease and drywell radioactivity.

\subsubsection{Leak Detected in 1974-1975}

Tank U-110 was first suspected of leaking on July 9, 1975 after a 0.5 -in liquid level decrease was observed. A drywell installed in 1974 (60-10-07) and a direct push installed in 2007 (C5607) both indicated a liner leak with radioactivity detected in the south southwest portion of the tank likely at or near the bottom of the tank (see Figure 5-17). The drywell 60-10-07 radioactivity detected in 1974 may have been an early indication of a liner leak but a liquid level decrease during that time was probably masked by tank pumping and transfer operations. 
Figure 5-17. Tank U-110 Possible Leak Location (1974-1975)

Tank inner ring is steel liner; outer ring is outer edge of tank footing

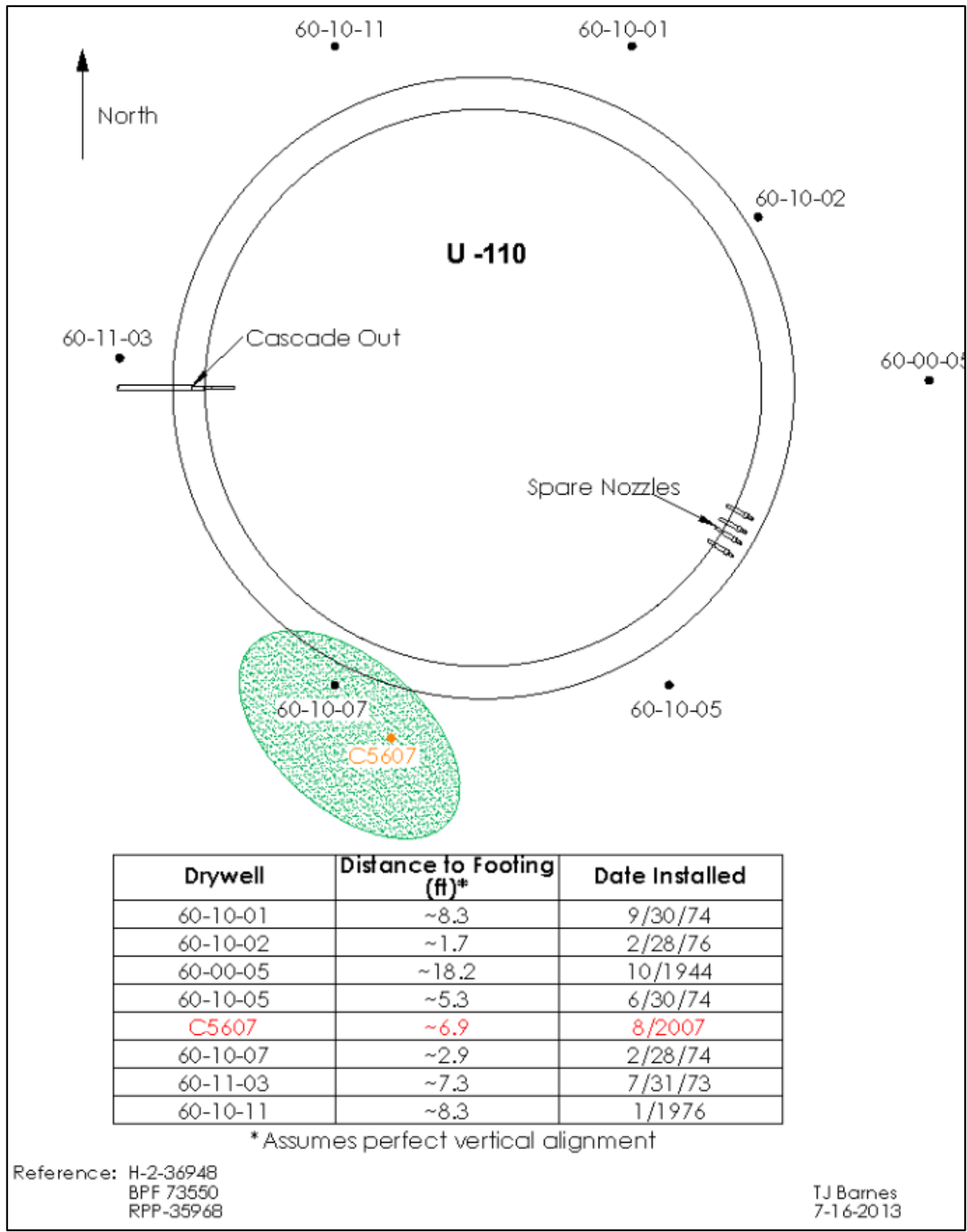

Tank U-110 was first suspected of leaking due to a 0.5-in liquid level decrease from May 24 to June 26, 1975, radioactivity increased in drywell 60-10-07 during this time. 
RPP-RPT-54915, Rev. 0

\subsection{POSSIBLE TANK U-110 LINER LEAK CAUSE(S)}

Tank U-110 was evaluated for five conditions known to contribute to a failed liner.

\subsubsection{Tank Design}

The U Farm tank design should not have been a factor contributing to a failed liner in spite of the tank U-104 experience (see Section 3.1.1).

\subsubsection{Thermal Conditions}

Limited temperature data are available for tank U-110 and no temperature data are available during the storage of REDOX concentrated salt waste. The temperature during REDOX waste storage resulted in a gradual decrease in liquid level indicating the temperature may have been higher at that time as the liquid level decrease was attributed to evaporation. Temperatures after storage of REDOX waste gradually decreased from $\sim 140^{\circ} \mathrm{F}$ to $\sim 115^{\circ} \mathrm{F}$ over a period of a year.

Thermal shock creates stress both from rapid temperature rise as well as waste-induced high temperatures. Since no records are available during a period of evaporation, it is uncertain what the maximum temperature was in tank U-110 during operation as well as the rate of temperature rise when waste was added. The thermal attributes of the waste and other information (see Section 5.4.2) would indicate that thermal stresses were likely minimal and should not have challenged the tank storage limits.

Temperature requirements in ARH-951 (Limitations for Use of Underground Waste Tanks) issued December 18, 1969 indicated that tank temperatures should be held below $230^{\circ} \mathrm{F}$.

\subsubsection{Chemistry-Corrosion}

Tank U-110 stored REDOX concentrated salt waste for $\sim 1.5$ years at elevated temperatures $\sim 19$ years before the liner leak. REDOX waste under high heat conditions could have resulted in pitting or SCC under tank U-110 conditions. The chemical content of the laboratory waste could not be recovered and normally would be diluted; however, the quantity of $361 \mathrm{kgal}$ over three years leads to some uncertainty. Other waste types stored in tank U-110 should not have resulted in pitting or SCC.

\subsubsection{Liner Observations}

A review of the available photographs for tank U-110 does not contain any evidence pointing to a tank leak. There is no documentation available indicating a liner bulge was present in the tank.

\subsubsection{Tank Construction Temperature}

The U Farm tank liners were constructed between February 1944 and October 1944. Only isolated minimum temperature were experienced during tank construction at or below $18^{\circ} \mathrm{F}$ with day time temperatures between $44^{\circ} \mathrm{F}$ and $57^{\circ} \mathrm{F}$ (see Section 5.3.2). Impact occurrences could have occurred during cold temperatures that may have triggered fissures in the steel liner; 
however, the possibility seems much less than that which might have occurred during construction in other tank farms.

\subsection{TANK U-110 CONCLUSIONS}

Liquid level evidence and drywell radioactivity indicate that the tank U-110 liner leaked in at least one location in the south southwest portion of the tank at or near the tank base.

There are several liner leak cause conditions that were examined and the likely one that might have caused the tank U-110 liner leak was pitting and SCC from the storage of REDOX concentrated salt waste or possible laboratory waste. However, the length of time from storage of REDOX waste at elevated temperatures to evidence of a tank liner leak was $\sim 19$ years. The unknown laboratory waste chemicals contained in the $316 \mathrm{kgal}$ transferred to tank U-110, 3 years prior to detecting the liner leak, may have had a corrosive influence.

There appears to be very little contribution from other wastes as well as from tank design and construction temperatures. However, some or all of the factors can act serially or together to contribute to tank liner failure. 
RPP-RPT-54915, Rev. 0

APPENDIX A2

TANK U-110 GROSS GAMMA DRYWELL DATA 
RPP-RPT-54914, Rev. 0

Table A2-1. Tank U-110 Drywell Radioactivity (K counts per minute) (August 1973 through September 1986) (SD-WM-TI-356) (2 pages)

\begin{tabular}{|c|c|c|c|c|c|c|c|c|c|c|c|c|c|c|}
\hline \multirow{2}{*}{\multicolumn{2}{|c|}{$\begin{array}{c}60-11-03 \\
\text { Drilled 7/31/73 }\end{array}$}} & \multirow{2}{*}{\multicolumn{2}{|c|}{$\begin{array}{c}\text { 60-10-01 } \\
\text { Drilled 9/30/74 }\end{array}$}} & \multirow{2}{*}{\multicolumn{2}{|c|}{$\begin{array}{c}60-10-02 \\
\text { Drilled 2/28/76 } \\
\end{array}$}} & \multirow{2}{*}{\multicolumn{2}{|c|}{$\begin{array}{c}60-00-05 \\
\text { Drilled 10/1944 } \\
\end{array}$}} & \multirow{2}{*}{\multicolumn{2}{|c|}{$\begin{array}{c}60-10-05 \\
\text { Drilled 6/30/74 } \\
\end{array}$}} & \multirow{2}{*}{\multicolumn{3}{|c|}{$\begin{array}{c}60-10-07 \\
\text { Drilled 2/28/74 } \\
\end{array}$}} & \multirow{2}{*}{\multicolumn{2}{|c|}{$\begin{array}{c}60-10-11 \\
\text { Drilled 01/1976 } \\
\end{array}$}} \\
\hline & & & & & & & & & & & & & & \\
\hline Date & $\begin{array}{c}\text { Peak } \\
(\mathrm{K} \\
\text { cpm) }\end{array}$ & Date & $\begin{array}{c}\text { Peak } \\
(\mathrm{K} \\
\text { cpm) }\end{array}$ & Date & $\begin{array}{c}\text { Peak } \\
(K \\
\text { cpm) }\end{array}$ & Date & $\begin{array}{c}\text { Peak } \\
(\mathrm{K} \\
\text { cpm) }\end{array}$ & Date & $\begin{array}{c}\text { Peak } \\
(\mathrm{K} \\
\text { cpm) }\end{array}$ & Date & $\begin{array}{c}\text { Peak } \\
(\mathrm{K} \\
\text { cpm) }\end{array}$ & $\begin{array}{c}\text { Depth } \\
\text { (ft) }\end{array}$ & Date & $\begin{array}{c}\text { Peak } \\
(\mathrm{K} \\
\text { cpm) }\end{array}$ \\
\hline $9 / 21 / 1973$ & $<12$ & \multicolumn{2}{|c|}{$\mathrm{N} / \mathrm{A}^{1}$} & \multicolumn{2}{|c|}{ N/A ${ }^{1}$} & $8 / 23 / 1973$ & $<12$ & \multicolumn{2}{|c|}{$\mathrm{N} / \mathrm{A}^{1}$} & \multicolumn{3}{|c|}{ N/A ${ }^{1}$} & \multicolumn{2}{|l|}{$\mathrm{N} / \mathrm{A}^{1}$} \\
\hline $6 / 7 / 1974$ & $<12$ & \multicolumn{2}{|l|}{$\mathrm{N} / \mathrm{A}^{1}$} & \multicolumn{2}{|c|}{ N/A ${ }^{1}$} & $4 / 18 / 1974$ & $<12$ & \multicolumn{2}{|l|}{$\mathrm{N}^{\prime} \mathrm{A}^{1}$} & $4 / 12 / 1974$ & 6.96 & 33 & \multicolumn{2}{|l|}{ N/A ${ }^{1}$} \\
\hline $8 / 29 / 1974$ & $<3$ & $9 / 27 / 1974$ & $<3$ & \multicolumn{2}{|c|}{$\mathrm{N}^{\prime} \mathrm{A}^{1}$} & 7/18/1974 & $<3$ & $7 / 19 / 1974$ & $<3$ & 8/1/1974 & 13.5 & 34 & \multicolumn{2}{|l|}{ N/A $^{1}$} \\
\hline $2 / 8 / 1975$ & $<3$ & $1 / 30 / 1975$ & $<3$ & \multicolumn{2}{|c|}{$\mathrm{N}^{\prime} \mathrm{A}^{1}$} & $1 / 30 / 1975$ & $<3$ & $2 / 5 / 1975$ & $<3$ & $2 / 13 / 1975$ & 13.74 & 35 & N/A ${ }^{1}$ & \\
\hline \multirow{2}{*}{\multicolumn{2}{|c|}{$\mathrm{N} / \mathrm{A}^{1}$}} & \multirow{2}{*}{\multicolumn{2}{|c|}{ N/A ${ }^{1}$}} & \multirow{2}{*}{\multicolumn{2}{|c|}{ N/A ${ }^{1}$}} & \multirow{2}{*}{\multicolumn{2}{|c|}{ N/A ${ }^{1}$}} & \multirow{2}{*}{\multicolumn{2}{|c|}{ N/A ${ }^{1}$}} & \multirow{2}{*}{$5 / 14 / 1975$} & 13.98 & 38 & \multirow{2}{*}{\multicolumn{2}{|c|}{ N/A ${ }^{1}$}} \\
\hline & & & & & & & & & & & 3.3 & 54 & & \\
\hline \multirow{2}{*}{\multicolumn{2}{|c|}{$\mathrm{N} / \mathrm{A}^{1}$}} & \multirow{2}{*}{\multicolumn{2}{|c|}{$\mathrm{N} / \mathrm{A}^{1}$}} & N/A ${ }^{1}$ & & & & & & $6 / 23 / 1975$ & 14.64 & 38 & N/A ${ }^{1}$ & \\
\hline & & & & & & N/A ${ }^{1}$ & & N/A ${ }^{1}$ & & & 8.1 & 53 & & \\
\hline $\mathrm{N}^{\prime} \mathrm{A}^{1}$ & & $\mathrm{~N} / \mathrm{A}^{1}$ & & N/A ${ }^{1}$ & & $\mathrm{~N} / \mathrm{A}^{1}$ & & N/A ${ }^{1}$ & & $6 / 30 / 1975$ & 15.6 & 53 & N/A ${ }^{1}$ & \\
\hline N/A ${ }^{1}$ & & N/A ${ }^{1}$ & & $\mathrm{~N} / \mathrm{A}^{1}$ & & N/A ${ }^{1}$ & & N/A ${ }^{1}$ & & $7 / 9 / 1975$ & 27 & 55 & N/A ${ }^{1}$ & \\
\hline N/A ${ }^{1}$ & & N/A ${ }^{1}$ & & $\mathrm{~N}^{\prime} \mathrm{A}^{1}$ & & N/A ${ }^{1}$ & & N/A ${ }^{1}$ & & $7 / 15 / 1975$ & 48.24 & 54 & N/A ${ }^{1}$ & \\
\hline $\mathrm{N} / \mathrm{A}^{1}$ & & N/A ${ }^{1}$ & & $\mathrm{~N}^{\prime} \mathrm{A}^{1}$ & & N/A ${ }^{1}$ & & N/A ${ }^{1}$ & & $7 / 23 / 1975$ & 106.08 & 54 & N/A ${ }^{1}$ & \\
\hline N/A ${ }^{1}$ & & $\mathrm{~N} / \mathrm{A}^{1}$ & & $\mathrm{~N} / \mathrm{A}^{1}$ & & N/A ${ }^{1}$ & & $\mathrm{~N} / \mathrm{A}^{1}$ & & $7 / 29 / 1975$ & 12 & 39 & $\mathrm{~N} / \mathrm{A}^{1}$ & \\
\hline & & & & & & & & & & & 155.88 & 55 & & \\
\hline $8 / 11 / 1975$ & $<3$ & $8 / 6 / 1975$ & $<3$ & $\mathrm{~N} / \mathrm{A}^{1}$ & & $8 / 5 / 1975$ & $<3$ & $8 / 6 / 1975$ & $<3$ & $8 / 6 / 1975$ & 242.4 & 53 & N/A ${ }^{1}$ & \\
\hline $12 / 30 / 1975$ & $<3$ & $12 / 30 / 1975$ & $<3$ & N/A ${ }^{1}$ & & $12 / 30 / 1975$ & $<3$ & $12 / 30 / 1975$ & $<3$ & $12 / 30 / 1975$ & 1367.1 & 54 & N/A ${ }^{1}$ & \\
\hline $5 / 5 / 1976$ & $<3$ & $5 / 5 / 1976$ & $<3$ & $5 / 12 / 1976$ & $<3$ & $5 / 12 / 1976$ & $<3$ & $5 / 5 / 1976$ & $<3$ & $5 / 11 / 1976$ & 16.38 & 52 & $5 / 12 / 1976$ & $<3$ \\
\hline N/A ${ }^{1}$ & & N/A ${ }^{1}$ & & $\mathrm{~N}^{\prime} \mathrm{A}^{1}$ & & N/A ${ }^{1}$ & & N/A ${ }^{1}$ & & & N/A ${ }^{1}$ & & $6 / 30 / 1976$ & $<3$ \\
\hline N/A ${ }^{1}$ & & N/A ${ }^{1}$ & & $\mathrm{~N}^{\prime} \mathrm{A}^{1}$ & & N/A ${ }^{1}$ & & N/A ${ }^{1}$ & & $8 / 3 / 1976$ & 15.6 & 52 & $8 / 10 / 1976$ & $<3$ \\
\hline N/A ${ }^{1}$ & & N/A ${ }^{1}$ & & $\mathrm{~N} / \mathrm{A}^{1}$ & & N/A ${ }^{1}$ & & N/A ${ }^{1}$ & & $11 / 2 / 1976$ & 25.2 & 52 & N/A ${ }^{1}$ & \\
\hline $1 / 5 / 1977$ & $<3$ & $1 / 14 / 1977$ & $<3$ & $1 / 5 / 1977$ & $<3$ & $1 / 5 / 1977$ & $<3$ & $1 / 5 / 1977$ & $<3$ & $4 / 5 / 1977$ & 61.68 & 52 & $1 / 5 / 1977$ & $<3$ \\
\hline N/A ${ }^{1}$ & & N/A ${ }^{1}$ & & N/A ${ }^{1}$ & & N/A ${ }^{1}$ & & N/A ${ }^{1}$ & & 8/2/1977 & 85.5 & 52 & N/A ${ }^{1}$ & \\
\hline $11 / 23 / 1977$ & $<3$ & $11 / 22 / 1977$ & $<3$ & $11 / 1 / 1977$ & $<3$ & $11 / 1 / 1977$ & $<3$ & $11 / 1 / 1977$ & $<3$ & $11 / 1 / 1977$ & 138.36 & 52 & $11 / 1 / 1977$ & $<3$ \\
\hline N/A ${ }^{1}$ & & N/A ${ }^{1}$ & & $\mathrm{~N}^{\prime} \mathrm{A}^{1}$ & & N/A ${ }^{1}$ & & N/A ${ }^{1}$ & & $3 / 7 / 1978$ & 155.16 & 50 & $11 / 15 / 1978$ & $<3$ \\
\hline
\end{tabular}


RPP-RPT-54914, Rev. 0

\begin{tabular}{|c|c|c|c|c|c|c|c|c|c|c|c|c|c|c|}
\hline \multicolumn{2}{|c|}{$\begin{array}{c}60-11-03 \\
\text { Drilled 7/31/73 }\end{array}$} & \multicolumn{2}{|c|}{$\begin{array}{c}60-10-01 \\
\text { Drilled 9/30/74 }\end{array}$} & \multicolumn{2}{|c|}{$\begin{array}{c}60-10-02 \\
\text { Drilled 2/28/76 }\end{array}$} & \multicolumn{2}{|c|}{$\begin{array}{c}\text { 60-00-05 } \\
\text { Drilled 10/1944 }\end{array}$} & \multicolumn{2}{|c|}{$\begin{array}{c}\text { 60-10-05 } \\
\text { Drilled 6/30/74 }\end{array}$} & \multicolumn{3}{|c|}{$\begin{array}{c}\text { 60-10-07 } \\
\text { Drilled 2/28/74 }\end{array}$} & \multicolumn{2}{|c|}{$\begin{array}{c}\text { 60-10-11 } \\
\text { Drilled 01/1976 }\end{array}$} \\
\hline Date & $\begin{array}{c}\text { Peak } \\
(\mathrm{K} \\
\text { cpm) }\end{array}$ & Date & $\begin{array}{c}\text { Peak } \\
(\mathrm{K} \\
\text { cpm })\end{array}$ & Date & $\begin{array}{c}\text { Peak } \\
(\mathrm{K} \\
\text { cpm) }\end{array}$ & Date & $\begin{array}{c}\text { Peak } \\
(\mathrm{K} \\
\text { cpm })\end{array}$ & Date & $\begin{array}{c}\text { Peak } \\
(\mathrm{K} \\
\text { cpm) }\end{array}$ & Date & $\begin{array}{c}\text { Peak } \\
(\mathrm{K} \\
\text { cpm })\end{array}$ & $\begin{array}{c}\text { Depth } \\
\text { (ft) }\end{array}$ & Date & $\begin{array}{c}\text { Peak } \\
(\mathrm{K} \\
\mathrm{cpm})\end{array}$ \\
\hline \multicolumn{2}{|c|}{ N/A ${ }^{1}$} & \multicolumn{2}{|l|}{$\mathrm{N}^{\prime} \mathrm{A}^{1}$} & \multicolumn{2}{|l|}{ N/A ${ }^{1}$} & \multicolumn{2}{|c|}{ N/A ${ }^{1}$} & \multicolumn{2}{|l|}{ N/A ${ }^{1}$} & 4/4/1978 & 27.18 & 52 & \multicolumn{2}{|c|}{ N/A ${ }^{1}$} \\
\hline $11 / 15 / 1978$ & $<3$ & $11 / 15 / 1978$ & $<3$ & $11 / 15 / 1978$ & $<3$ & $11 / 15 / 1978$ & $<3$ & $11 / 15 / 1978$ & $<3$ & $11 / 6 / 1978$ & 37.44 & 52 & \multicolumn{2}{|c|}{ N/A ${ }^{1}$} \\
\hline $11 / 1 / 1979$ & $<3$ & $11 / 1 / 1979$ & $<3$ & $11 / 1 / 1979$ & $<3$ & $10 / 31 / 1979$ & $<3$ & $11 / 1 / 1979$ & $<3$ & $10 / 22 / 1979$ & 49.26 & 51 & $11 / 1 / 1979$ & $<3$ \\
\hline $11 / 13 / 1980$ & $<3$ & $11 / 13 / 1980$ & $<3$ & $11 / 13 / 1980$ & $<3$ & $11 / 13 / 1980$ & $<3$ & $11 / 13 / 1980$ & $<3$ & $11 / 17 / 1980$ & 47.22 & 53 & $11 / 13 / 1980$ & $<3$ \\
\hline $11 / 19 / 1981$ & $<3$ & $11 / 19 / 1981$ & $<3$ & $11 / 19 / 1981$ & $<3$ & $11 / 11 / 1981$ & $<3$ & $11 / 19 / 1981$ & $<3$ & $11 / 16 / 1981$ & 44.04 & 54 & $11 / 19 / 1981$ & $<3$ \\
\hline $11 / 3 / 1982$ & $<3$ & $11 / 3 / 1982$ & $<3$ & $11 / 3 / 1982$ & $<3$ & $10 / 12 / 1982$ & $<3$ & $11 / 3 / 1982$ & $<3$ & $10 / 20 / 1982$ & 52.5 & 53 & $11 / 3 / 1982$ & $<3$ \\
\hline $9 / 21 / 1983$ & $<3$ & $9 / 21 / 1983$ & $<3$ & $9 / 21 / 1983$ & $<3$ & $9 / 21 / 1983$ & $<3$ & $9 / 21 / 1983$ & $<3$ & $9 / 20 / 1983$ & 52.5 & 54 & $9 / 21 / 1983$ & $<3$ \\
\hline $8 / 23 / 1984$ & $<3$ & $8 / 22 / 1984$ & $<3$ & $8 / 22 / 1984$ & $<3$ & $8 / 23 / 1984$ & $<3$ & $8 / 22 / 1984$ & $<3$ & $8 / 20 / 1984$ & 53.58 & 54 & $8 / 22 / 1984$ & $<3$ \\
\hline $10 / 15 / 1985$ & $<3$ & $10 / 15 / 1985$ & $<3$ & $10 / 15 / 1985$ & $<3$ & $10 / 15 / 1985$ & $<3$ & $10 / 15 / 1985$ & $<3$ & $10 / 14 / 1985$ & 51.9 & 55 & $10 / 15 / 1985$ & $<3$ \\
\hline $9 / 17 / 1986$ & $<3$ & $9 / 17 / 1986$ & $<3$ & $9 / 17 / 1986$ & $<3$ & $9 / 17 / 1986$ & $<3$ & $9 / 17 / 1986$ & $<3$ & 9/17/1986 & 38.88 & 55 & $9 / 17 / 1986$ & $<3$ \\
\hline
\end{tabular}




\subsection{TANK 241-U-112 SEGMENT}

\section{TABLE OF CONTENTS}

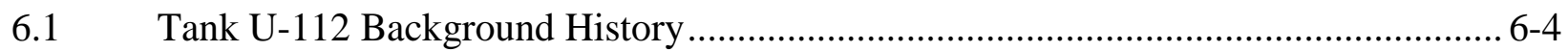

6.2 Tank U-112 Operations Summary …………....................................................... 6-5

6.3 Tank Design/Construction ………………............................................................... 6-7

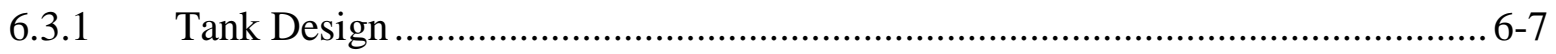

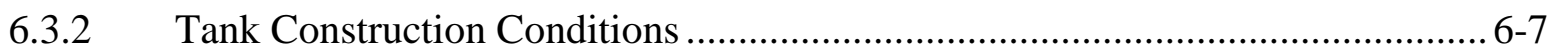

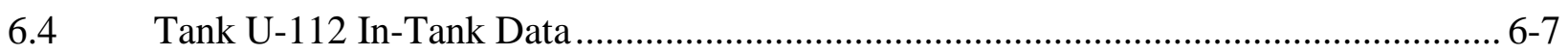

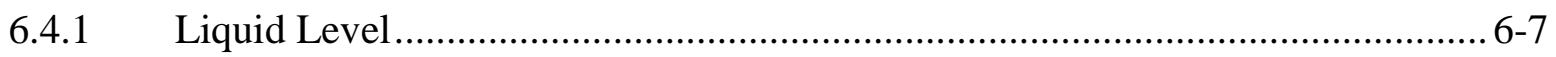

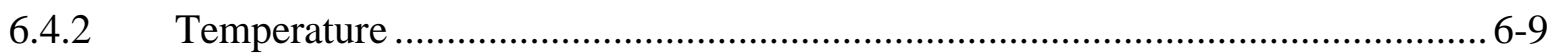

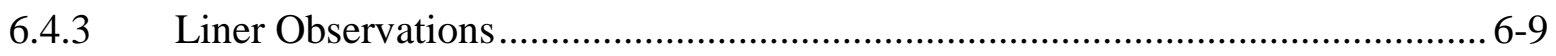

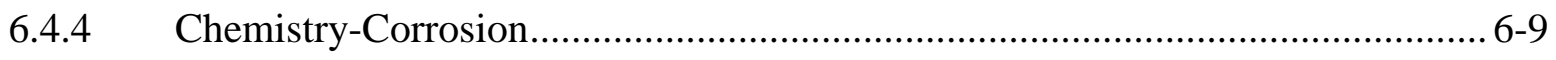

6.4.5 Photographs............................................................................................ 6-11

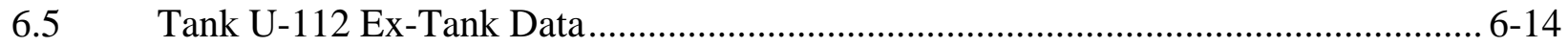

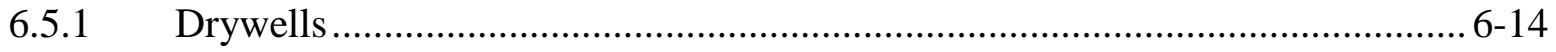

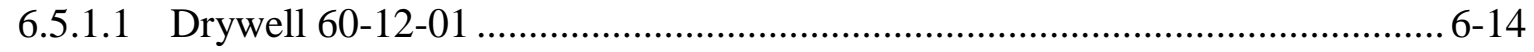

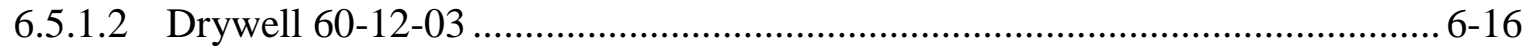

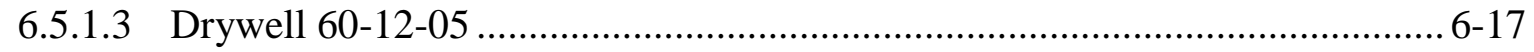

6.5.1.4 Drywell 60-12-07 ................................................................................ 6-18

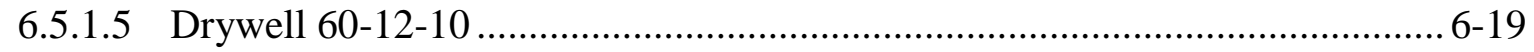

6.5.1.6 Drywell 60-00-08 ………………………....................................... 6-20

6.5.1.7 2007 Direct Push ................................................................................... 6-21

6.5.1.8 Drywell Summary ……………………………....................................... 6-21

6.6 Possible Tank U-112 Liner Leak Location(s) ...................................................... 6-21

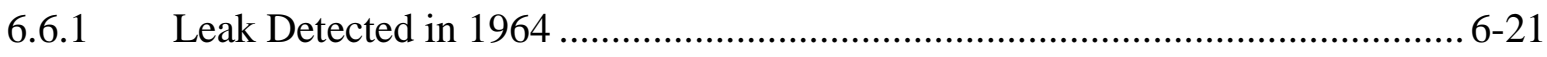

6.7 Possible Tank U-112 Liner Leak Cause(s) ............................................................ 6-23

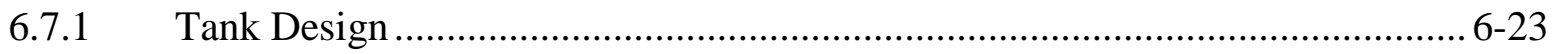

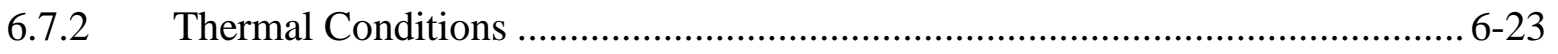

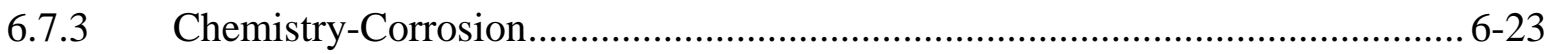

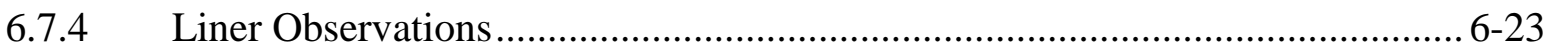




\section{Appendices}

Appendix A3 Tank U-112 Gross Gamma Drywell Data.

A3-1

\section{LIST OF FIGURES}

Figure 6-1. Tank U-112 Associated Drywells .................................................................. 6-4

Figure 6-2. Operational Leak History of Tank U-112 ................................................. 6-6

Figure 6-3. Tank U-112 End of Quarter Surface Level .................................................. 6-8

Figure 6-4. Tank U-112 Liquid Level June 1964 through March 1970 ................................. 6-9

Figure 6-5. Tank U-112 Photograph, June 5, 1975 ................................................... 6-11

Figure 6-6. Tank U-112 Photograph March 12, 1970 ................................................. 6-12

Figure 6-7. Tank U-112 Photograph March 12, 1970 .................................................. 6-13

Figure 6-8. T Farm Bottom Liner Deformation during Construction April 15, 1944 (D2314) 6-14

Figure 6-9. Tank U-112 Drywell 60-12-01 (RPP-7729) .................................................... 6-15

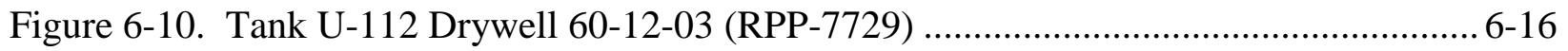

Figure 6-11. Tank U-112 Drywell 60-12-05 (RPP-7729) .............................................. 6-17

Figure 6-12. Tank U-112 Drywell 60-12-07 (RPP-7729) ............................................ 6-18

Figure 6-13. Tank U-112 Drywell 60-12-10 (RPP-7729) .............................................. 6-19

Figure 6-14. Tank U-112 Drywell 60-00-08 (RPP-7729) ............................................... 6-20

Figure 6-15. Tank U-112 Possible Leak Location (1964) ............................................. 6-22 


\section{RPP-RPT-54915, Rev. 0}

\section{LIST OF TABLES}

Table 6-1. Tank U-112 Waste Storage Chronology ........................................................... 6-10

Table 6-2. Waste Chemistries for Waste Types Stored in Tank U-112 ............................... 6-10

Table A3-1. Tank U-112 Drywell Radioactivity (K counts per minute)

(August 1974 through October 1986) ...........................................................A3-2 


\subsection{TANK U-112 BACKGROUND HISTORY}

This section provides information on the historical waste loss event associated with Single-Shell Tank (SST) 241-U-112 (U-112). There are six drywells located around tank U-112 with specified distances from the drywell to the tank footing shown in Figure 6-1: 60-00-08, installed in 1944, 60-12-05, 60-12-07, and 60-12-10 installed in 1970, 60-12-03, installed in 1973, and 6012-01 installed in 1974. One nearby direct push, C5605, was installed in 2007.

The bottom of the tank footing is $\sim 38$ - $\mathrm{ft}$ Below Grade Surface (BGS) with $\sim 6$ - $\mathrm{ft}$ soil cover over the dome (WHC-SD-WM-TI-665; BPF-73550).

Figure 6-1. Tank U-112 Associated Drywells

Tank inner ring is steel liner; outer ring is outer edge of tank footing

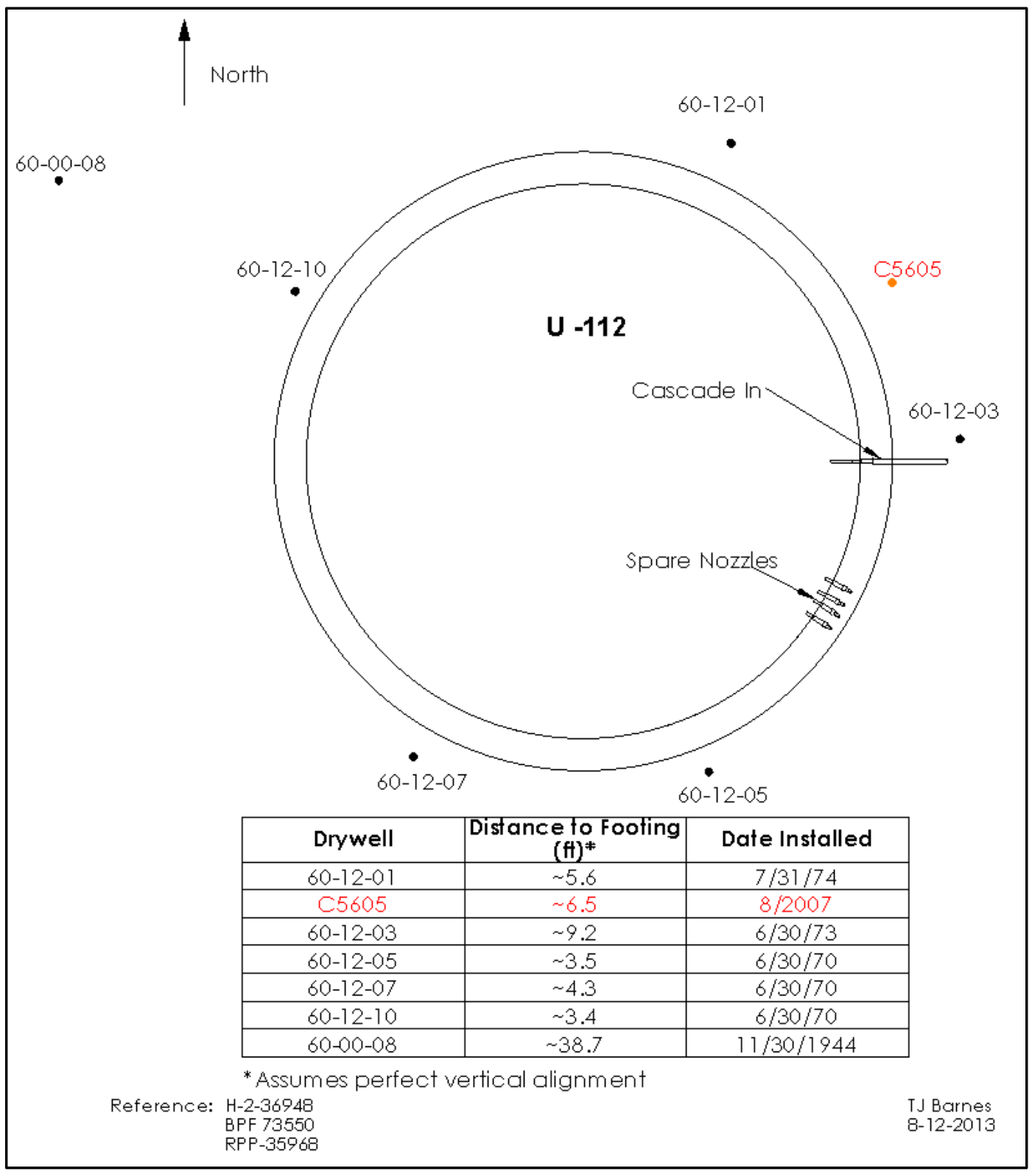


RPP-RPT-54915, Rev. 0

\subsection{TANK U-112 OPERATIONS SUMMARY}

Tank U-112 first began receiving 221-T Plant (T Plant) first cycle waste (1C) typically neutralized with coating waste (CW) cascaded from tank U-111 in October 1947 (RPP-RPT50097, Rev. 0). Tank U-112 is the third tank in the three tank cascade series which includes tanks U-110 and U-111. Tank U-112 was declared full in May 1948 (HW-10166-DEL, Hanford Works Monthly Report May 1948). No other transfers occurred through July 1951 and no records of tank transfers were available from August 1951 through March 1952.

By the end of April 1952, the supernatant was pumped out of tank U-112 as the waste volume was reported as $32 \mathrm{kgal}$; however, the tank that received this waste was not recorded (HW27838). No additional transfers occurred through December 1953.

Beginning on January 13, 1954, concentrated salt waste from the REDOX plant continued to be transferred to tank U-110, which cascaded to tanks U-111 and U-112 through April 22, 1954. During this period, tank U-112 was filled to its nominal operating capacity of $514 \mathrm{kgal}$ (HW31811, Separations Section Waste - Status Summary April 30, 1954, page 5). No additional waste was added to tank U-112 from April 22, 1954 through August 1955, and the waste volume in the tank remained unchanged from $514 \mathrm{kgal}$.

In May 1956, approximately $21 \mathrm{kgal}$ of REDOX cladding (coating) waste (CW) was transferred from tank U-110 to tank U-112 (HW-43490, page 6). The volume of waste stored in tank U-112 was reported as $530 \mathrm{kgal}$ following this transfer. Based on the reported volume of waste in tank U-112 in April 1954 (514 kgal) and May 1956 (530 kgal) following the transfer of CW (21 kgal) into tank U-112, there is an apparent $5 \mathrm{kgal}$ discrepancy in the material balance for this transfer.

No additional waste was added to tank U-112 after May 1956. However, a new electrode measurement of the volume of waste stored in tank U-112 was conducted in January 1957 and reported as $549 \mathrm{kgal}$ (HW-48144, Chemical Processing Department Waste - Status Summary January 1, 1957 - January 31, 1957, page 6). The volume of solids in tank U-112 was reported as $32 \mathrm{kgal}$. The reported volume of waste in tank U-112 remained unchanged from January 1957 through June 30, 1964. No additional transfers occurred through December 1969.

Tank U-112 was first suspected of leaking based on a 3-in liquid level decrease between February 1969 and March 1970 and classified as a "questionable integrity" tank (RHO-CD-896). Tank U-112 was pumped to a minimum heel of 24.5-in and removed from service in March 1970.

From October 1974 through April 12, 1978, the remaining pumpable liquid in tank U-112 was removed using a saltwell pump (DS-103174, Data Sheet Salt Well Transfer: Tk 112U to Tk$109 U$ ). Tank U-112 was declared administratively interim stabilized in September 1979. As of April 2013, tank U-112 contains $45 \mathrm{kgal}$ of sludge with $4 \mathrm{kgal}$ of drainable interstitial liquid (HNF-EP-0182).

The operational history of tank U-112 leak related details including liquid level is charted in Figure 6-2. 
RPP-RPT-54915, Rev. 0

\section{Figure 6-2. Operational Leak History of Tank U-112}

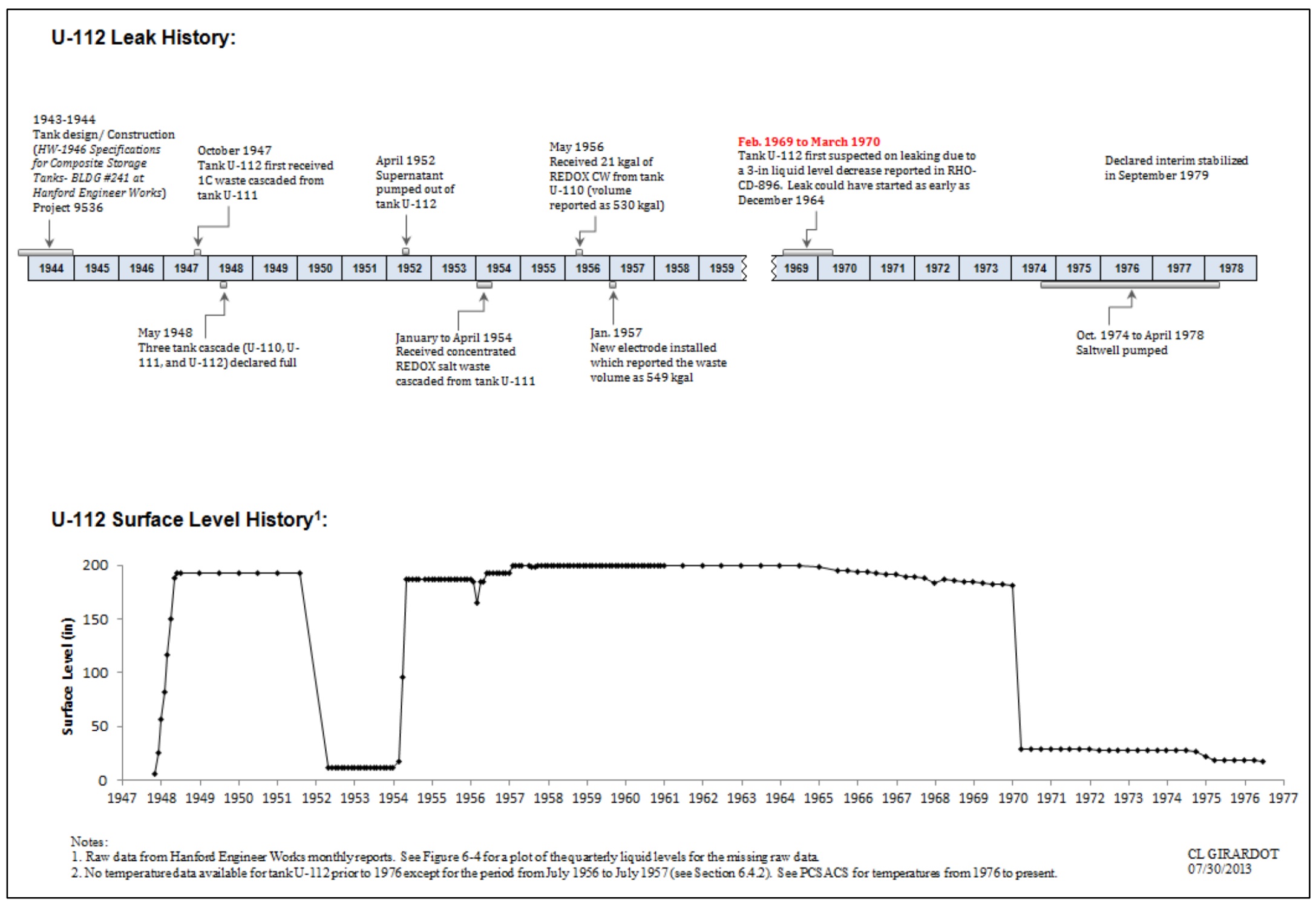


RPP-RPT-54915, Rev. 0

\subsection{TANK DESIGN/CONSTRUCTION}

\subsubsection{Tank Design}

The steel bottoms of the U Farm tanks intersect the sidewall on a 4-ft radius knuckle transition (BPF-73550, Drawings D-2 and D-3). The rounded knuckle transition, the three-ply asphaltic membrane waterproofing between the liner and the concrete, a notched footing construction joint, and the concrete shell are features common to all U Farm tanks (see Section 3.1.1).

\subsubsection{Tank Construction Conditions}

The U Farm tanks were constructed between February 1944 and October 1944. Temperatures are not available for 1944 between May 18 and December 1. From the start of U Farm tank construction through May 18, 1944 there were two minimum temperatures of $12^{\circ} \mathrm{F}$ with daytime temperatures of $44^{\circ} \mathrm{F}$ and $57^{\circ} \mathrm{F}$, one at $18^{\circ} \mathrm{F}$, and four at $20^{\circ} \mathrm{F}$ with day time temperatures between $41^{\circ} \mathrm{F}$ and $56^{\circ} \mathrm{F}$.

As described in Section 3.1.2, cold weather affects the ductile-to-brittle steel transition temperature, with $18^{\circ} \mathrm{F}$ being the assumed design temperature for the carbon steel liner, which could result in a fracture upon impact. However, in general, the temperatures during the U Farm construction time frame were much milder than those experienced during 241-SX Farm construction where ductile-to-brittle steel transition temperatures were exceeded.

Design, fabrication, and erection of the tank steel lining were required to be in accordance with current "Standards Specifications for Elevated Steel Water Tanks, Standpipes and Reservoirs" as promulgated by the "American Water Works Association" (BPF-73550). Welding requirements were required to conform to the American Welding Society's "Code for Arc and Gas Welding in Building Construction", Section 4.

\subsection{TANK U-112 IN-TANK DATA}

\subsubsection{Liquid Level}

The liquid level plot in Figure 6-3 indicates the transfer activity into and out of tank U-112. The liquid levels are end of quarter levels so this figure may not reflect all transfers into and out of

the tank that occurred during the operational history. See Figure 6-2 for historical monthly liquid level readings. 
Figure 6-3. Tank U-112 End of Quarter Surface Level

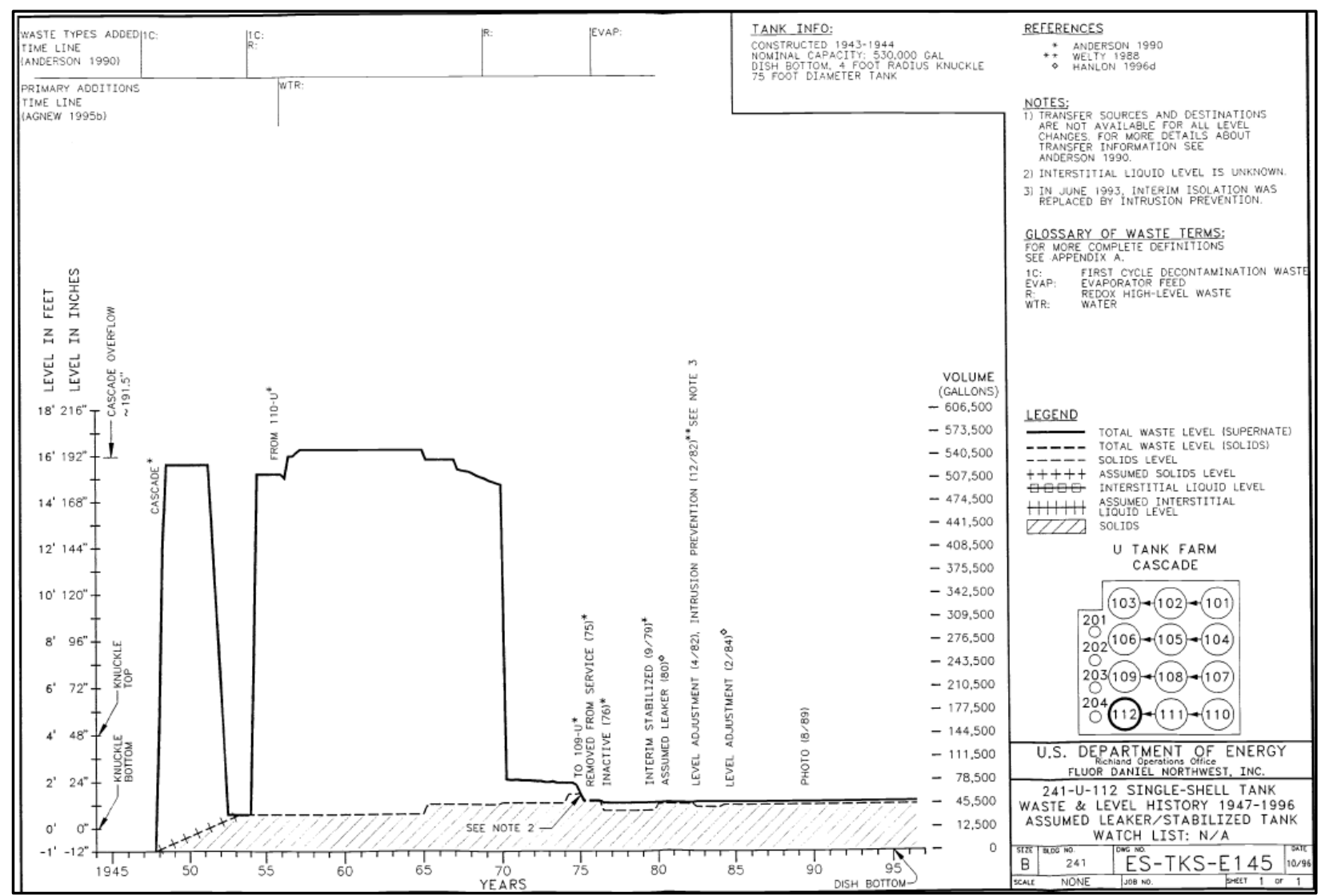

WHC-SD-WM-ER-325, Rev. 0, 1994, Supporting Document for the SW Quadrant Historical Tank Content Estimate for U-Tank Farm.

Tank U-112 was first suspected of leaking based on a 3-in liquid level decrease from 179-in in February 1969 to 176-in in March 1970 (RPP-CD-896). However, after reviewing historic liquid level data for tank U-112, it appears the leak could have started as early as December 1964 as the liquid level was declining in this earlier period (see Figure 6-4). It is not clear why RHO-CD896 selected February 1969 through March 1970 for the leak determination when monthly data taken from December 1964 through March 1970 indicates the liquid level was decreasing much earlier.

The reported volume of $549 \mathrm{kgal}$ in tank U-112 remained unchanged from January 1957 through June 30, 1964 and no transfers were reported during this time period. The next recoverable liquid level reading was reported December 31, 1964 and the waste volume was reported at 546 kgal (198.5-in). Liquid level readings continued to decline through December 1969 when the volume was reported as $498 \mathrm{kgal}$ (181.1-in) giving a total waste volume decrease of $47 \mathrm{kgal}$.

Before June 30, 1965 the liquid level was reported to be above 196.5-in, the location of the cascade inlet line penetration. Since the liquid level was above this location and near the time when the liquid level started to decrease, it is possible there was a small leak from the cascade inlet line. However, since the liquid level continued to decrease below the location of the cascade inlet penetration then this likely indicated a tank liner leak. A sidewall leak seems 
unlikely as peak radioactivity detected in drywell 60-12-01 was reported at approximately 50-ft BGS (see Section 6.5.1.1). It appears the leak is greater than the $8.5 \mathrm{kgal}$ reported in RHO-CD896 and could be as large as $47 \mathrm{kgal}$.

Figure 6-4. Tank U-112 Liquid Level June 1964 through March 1970

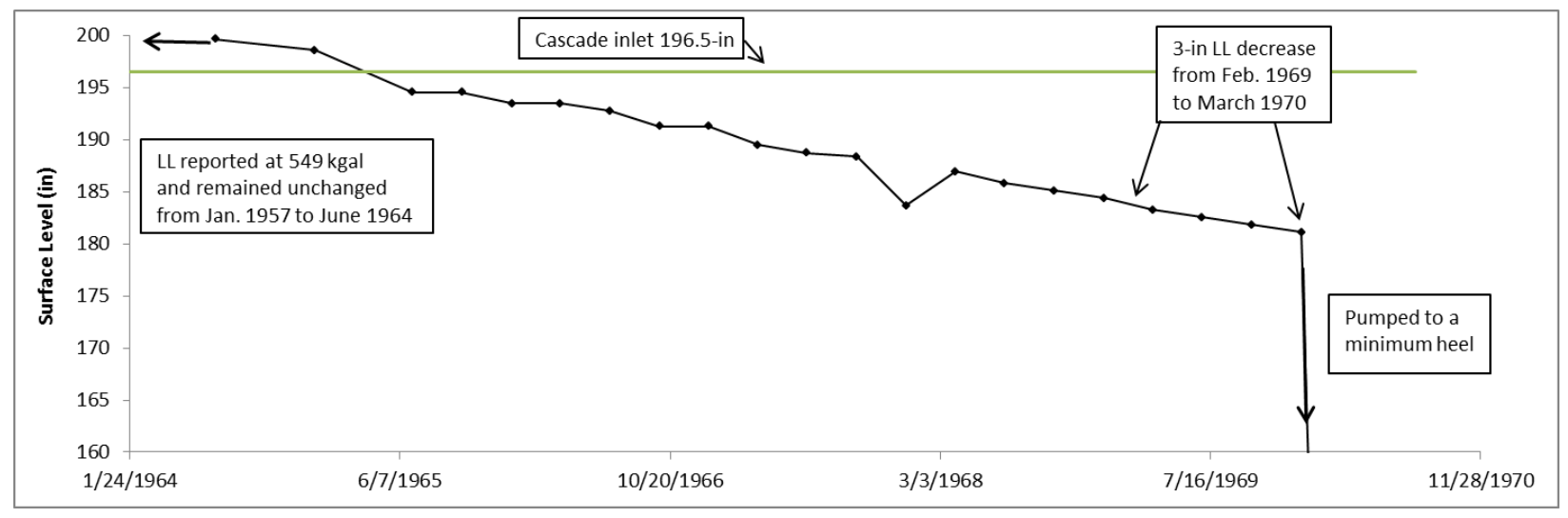

\subsubsection{Temperature}

No temperature data were recovered for tank U-112 from October 1947 when the tank was first put into service until July 1956. Sludge temperature plots for the one year period between July 1956 and July 1957 (RHO-CD-1172) indicated temperatures ranged from $\sim 70^{\circ} \mathrm{F}$ to $\sim 60^{\circ} \mathrm{F}$ with one spike in September 1956 at approximately $170^{\circ} \mathrm{F}$. The one year of temperature data started two months after a reported $21 \mathrm{kgal}$ of $\mathrm{CW}$ waste had been added to $514 \mathrm{kgal}$ of REDOX concentrated salt waste. There had been a gradual decrease in liquid level during storage of REDOX concentrated salt waste in tank U-110 but there was no liquid level decrease experienced in tank U-112 for the cascaded REDOX waste from tank U-110 through tank U-111. Tank U-112, the last tank in the tank U-110 cascade would have experienced lower temperatures than those experienced in tank U-110. Similar temperature experience in tank U-110 ranged from $\sim 140^{\circ} \mathrm{F}$ to $\sim 115^{\circ} \mathrm{F}$ which were $\sim 70^{\circ} \mathrm{F}$ to $\sim 50^{\circ} \mathrm{F}$ higher than tank $\mathrm{U}-112$. Average temperature for storage of REDOX and REDOX/CW waste was probably near $100^{\circ} \mathrm{F}$ based on the limited temperature data and the tank U-110 temperature information.

No temperature data were recovered for tank U-112 from July 1957 until 1976. Tank U-112 waste temperatures from 1976 to present which ranged from $\sim 60^{\circ} \mathrm{F}$ to $70^{\circ} \mathrm{F}$ can be found in PCSACS. The tank was pumped to minimum heel in March 1970 after the tank was suspected of leaking due to the liquid level decreasing.

\subsubsection{Liner Observations}

Tank U-112 bottom liner observations could possibly be related to a tank U-112 liner failure, see section 6.4.5.

\subsubsection{Chemistry-Corrosion}

Tank U-112 began receiving 1C waste typically neutralized with CW cascaded from tank U-111 in October 1947 and stored three waste types during operation as shown in Table 6-1. The 
typical concentration for nitrite, nitrate, and hydroxide for the waste types stored in tank U-112 is shown in Table 6-2. Nitrite and hydroxide are known as nitrate induced SCC inhibitors. One key characteristic for inhibiting SCC is to maintain a high nitrite concentration to nitrate concentration ratio (see Section 3.2.4).

Table 6-1. Tank U-112 Waste Storage Chronology

\begin{tabular}{|c|c|c|}
\hline Date & Waste Type & Length of Storage \\
\hline October 1947 to April 1952 & $1 \mathrm{C} / \mathrm{CW}$ & $\sim 5$ years \\
\hline January 1954 to May 1956 & $\mathrm{R}$ & $\sim 2$ years \\
\hline May 1956 to March 1970 & $\mathrm{R} / \mathrm{CW}$ & $\sim 14$ years \\
\hline
\end{tabular}

1. $\mathrm{R} / \mathrm{CW}$ ratio $514 \mathrm{kgal} / 21 \mathrm{kgal}$

Table 6-2. Waste Chemistries for Waste Types Stored in Tank U-112

\begin{tabular}{|c|c|c|c|c|}
\hline Waste Type & {$\left[\mathrm{NO}_{3}{ }^{-}\right]$} & {$\left[\mathrm{NO}_{2}^{-}\right]$} & {$\left[\mathrm{OH}^{-}\right]$} & $\begin{array}{c}\text { Meets Current } \\
\text { DST Specification }\end{array}$ \\
\hline $1 \mathrm{C}^{1}$ & 1.54 & 0.26 & 0.28 & $\mathrm{No}^{3}$ \\
\hline $\mathrm{CW}^{1}$ & 0.6 & 0.9 & 1.0 & Yes \\
\hline $\mathrm{R}^{4}$ & 4.83 & \multicolumn{2}{|c|}{0.74} & $\mathrm{No}^{5}$ \\
\hline
\end{tabular}

1. Reference WHC-EP-0449, 1991, The Sort on Radioactive Waste Type Model: A Method to Sort Single-Shell Tanks into Characteristic Groups.

2. Reference OSD-T-151-00007, Rev. 12, (2013), Operating Specifications for the Double-Shell Storage Tanks.

3. Waste type 1C does not meet the current DST specification for waste chemistry; however, 1C was mixed with CW prior to adding to the tank. Depending on this ratio, the resulting waste may have met the DST specification.

4. Reference WHC-EP-0772, 1994, Characterization of the Corrosion Behavior of the Carbon Steel Liner in Hanford Site Single-Shell Tanks.

5. Does not meet the current DST specification since the hydroxide and nitrite concentrations are not greater than or equal to $1.2 \mathrm{M}$.

Tank U-112 stored REDOX concentrated salt waste for $\sim 2$ years when $21 \mathrm{kgal}$ of CW was added to the existing $531 \mathrm{kgal}$ of REDOX waste. The resulting combination of REDOX waste and CW would not meet the current DST specification for waste chemistry (OSD-T-151-00007, Rev. 12). Therefore, the REDOX waste and the REDOX/CW waste would have been present in the tank for 10 years when the liquid level started decreasing in 1964 and would continue to be stored for another six years when the tank was pumped in 1970. The REDOX and REDOX/CW wastes could be a concern for either pitting or SCC under the tank U-112 conditions even though waste temperatures probably averaged less than $100^{\circ} \mathrm{F}$.

The other waste types stored in tank U-112 should not have resulted in pitting or SCC. The waste type $1 \mathrm{C} / \mathrm{CW}$ was a combination of the acidic $1 \mathrm{C}$ waste in $\mathrm{T}$ Plant neutralized with the basic $\mathrm{CW}$ in $\mathrm{T}$ Plant. Depending on the ratio of $1 \mathrm{C}$ to $\mathrm{CW}$, the resulting waste type likely met the OSD-T-151-0007 specification for waste chemistry since CW by itself meets the current DST specification. 


$$
\text { RPP-RPT-54915, Rev. } 0
$$

\subsubsection{Photographs}

The earliest photographs recovered for tank U-112 were dated June 5, 1975. The photograph in Figure 6-5 shows the cascade inlet line and what may be an indistinct beach line above the cascade inlet line that may be a sign the tank was overfilled.

Figure 6-5. Tank U-112 Photograph, June 5, 1975 (753800-1CN)

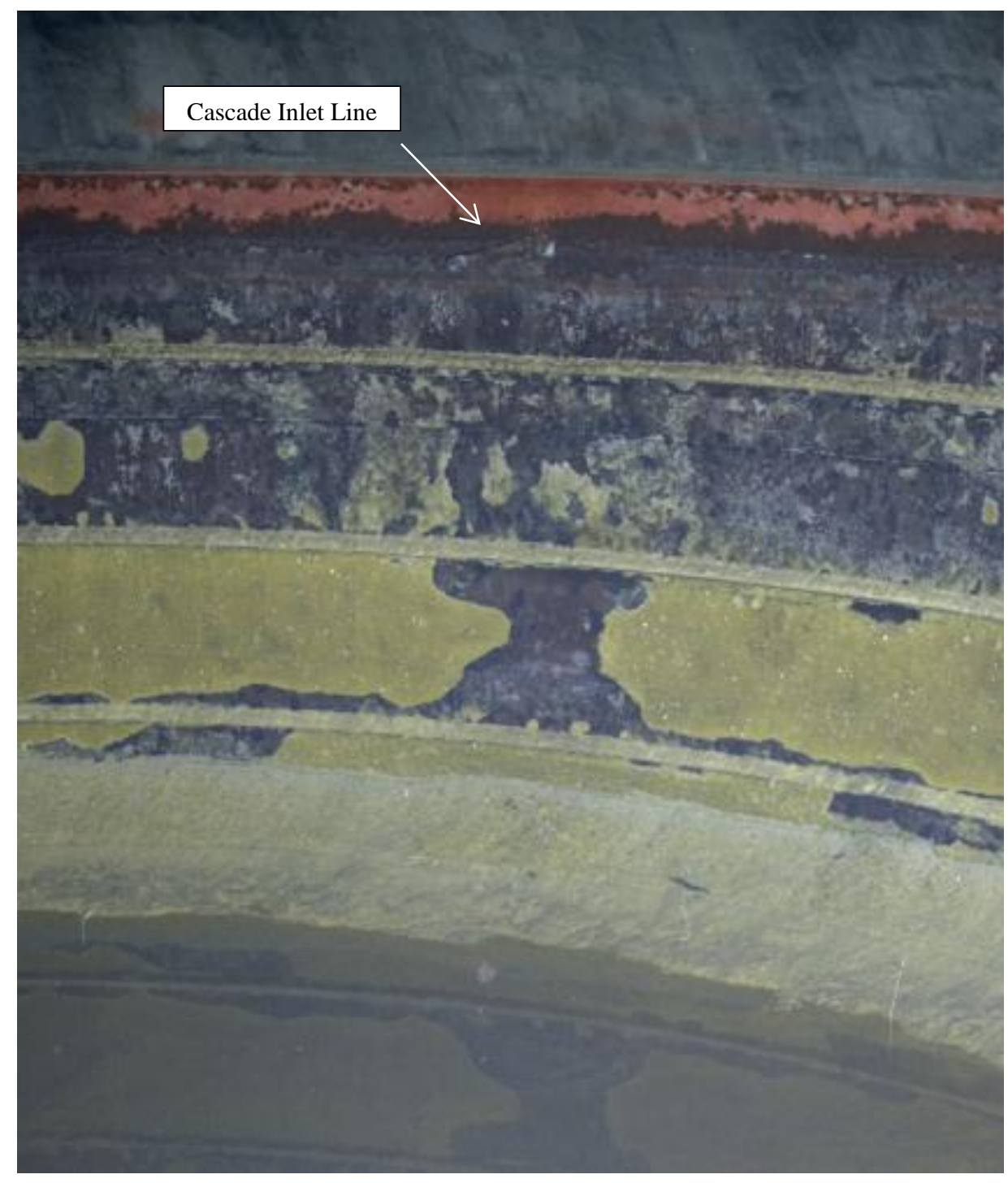


Photographs of the tank U-112 were taken on March 12, 1970 after pumping the tank to $~ 80 \mathrm{kgal}$ with $\sim 46 \mathrm{kgal}$ of sludge. The photographs in Figure 6-6 and Figure 6-7 show a pattern of solids below the liquid surface that appears to follow plate weld lines on the bottom tank liner. This could possibly be related to deformation of the bottom plates creating stresses in the plates and welds as the weight of waste increased during filling and emptying. The 241-T Farm tanks experienced buckling of the bottom liner during construction of the tanks (see Figure 6-8) and all of the 241-T Farm tank bottom liners required replacement (HW-7-103, Hanford Engineering Works Monthly Report April 1944). A similar buckling of some or all of the U Farm tanks may have occurred and was either not as severe or not recognized which may have resulted in the pattern seen in Figure 6-6 and Figure 6-7 for tank U-112.

Figure 6-6. Tank U-112 Photograph March 12, 1970

Apparent Weld Ridge Pattern

(701199-4CN) 
RPP-RPT-54915, Rev. 0

Figure 6-7. Tank U-112 Photograph March 12, 1970

Apparent Weld Ridge Pattern

(701199-5CN)

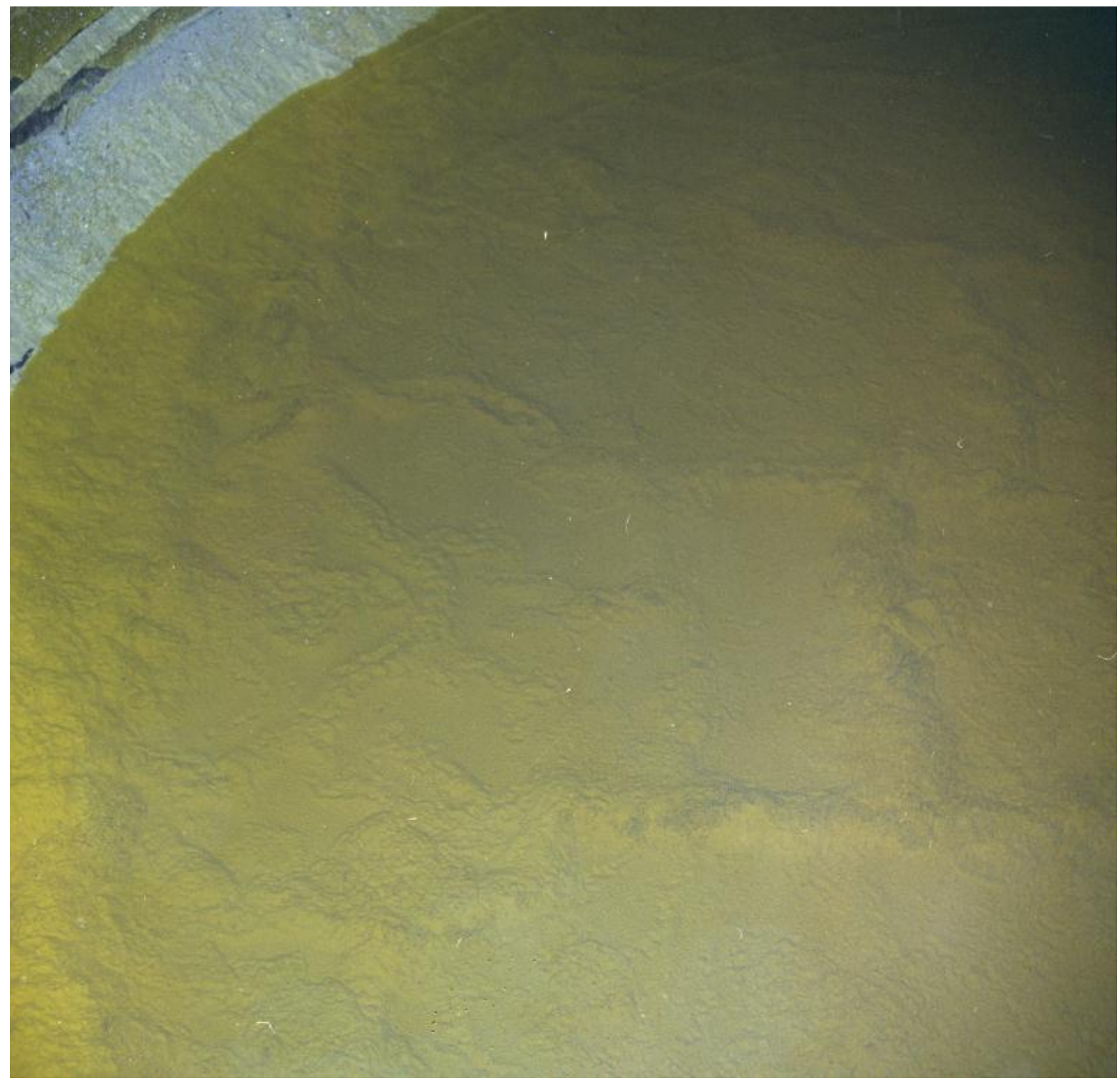




\section{Figure 6-8. 241-T Farm Bottom Liner Deformation during Construction April 15, 1944 \\ (D2314)}

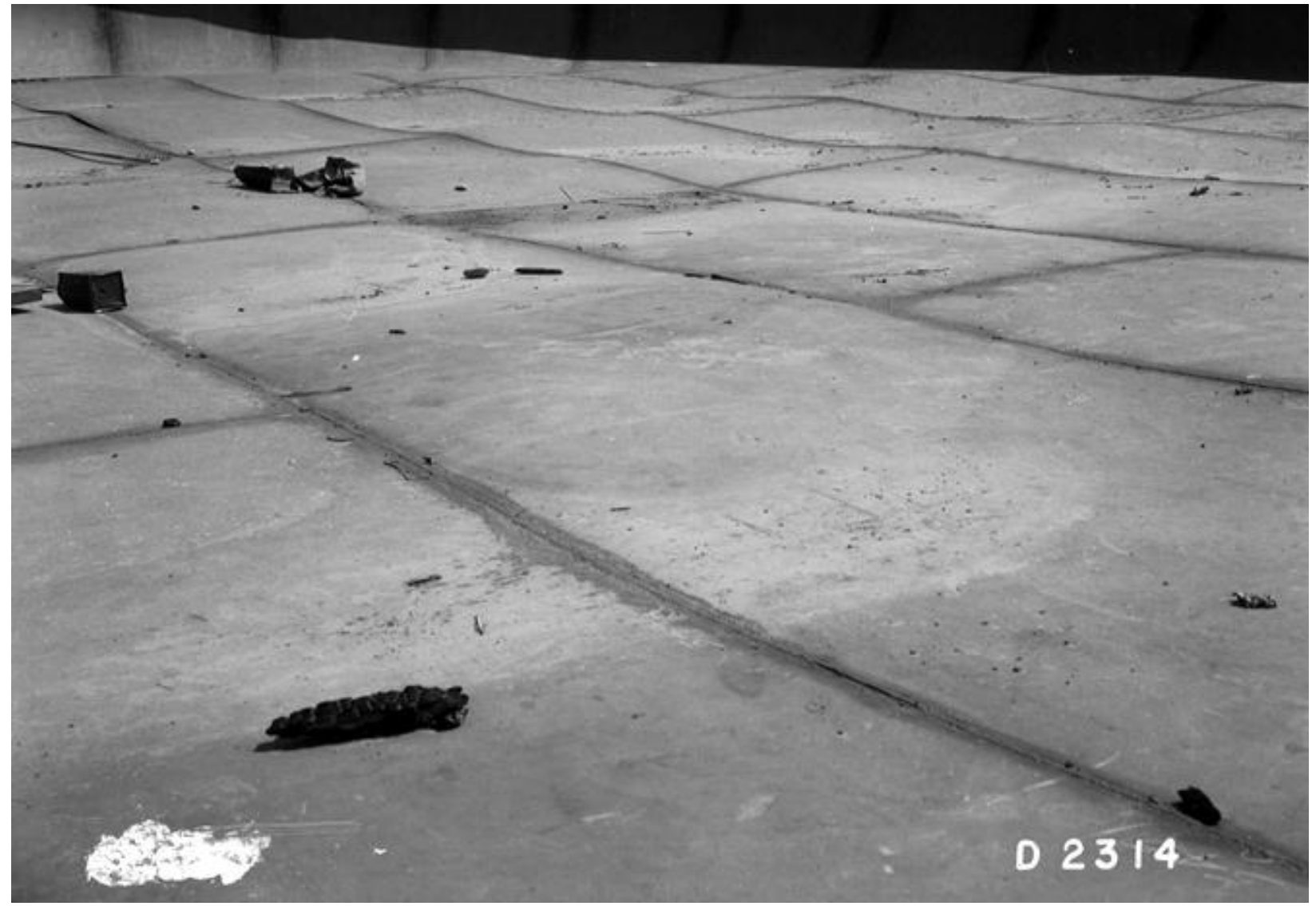

\subsection{TANK U-112 EX-TANK DATA}

\subsubsection{Drywells}

There are six drywells located around tank U-112: 60-00-08, installed in 1944, 60-12-05, 60-1207, and 60-12-10 installed in 1970, 60-12-03, installed in 1973, 60-12-01 installed in 1974, and a direct push installed in 2007. All of the radiation readings in drywells are assumed to be maximum or peak readings unless otherwise noted (see Section 3.3.2). The following subsections report the available drywell and direct push information including a summary and analysis section for tank U-112.

\subsubsection{Drywell 60-12-01}

Drywell 60-12-01 is located approximately 5.6-ft from the north northeast side of tank U-112. Drywell 60-12-01 was drilled in 1974 with the first recoverable reading on August 22, 1974 reported at 3,000K cpm at 50-ft BGS (see Appendix A3). The next recoverable reading reported a peak at $831.5 \mathrm{~K} \mathrm{cpm}$ at $53-\mathrm{ft}$ BGS. Readings remained relatively stable to March 7, 1977. Following the use of new monitoring equipment, the peak was reported at approximately $340 \mathrm{~K}$ 
cpm at 50-ft BGS. Readings continued to be reported at roughly the same radioactivity and BGS level through October 1986 (see Appendix A3).

In September 1996, significant Cs-137 contamination was detected in this drywell and contamination occurs continuously from the ground surface to the bottom (GJ-HAN-41, Vadose Zone Characterization Project at the Hanford Tank Farms Tank Summary Data Report for Tank $U-112)$. From the ground surface to 3.5-ft BGS, between 50 and $68-\mathrm{ft}$ and between 84 and $98-\mathrm{ft}$ BGS, Cs-137 concentrations exceeded 2,000 pCi/g. Between 17 and 50-ft BGS, Cs-137 concentrations ranged from 1 to $9 \mathrm{pCi} / \mathrm{g}$. Document GJ-HAN-41 reports, "The Cs-137 contamination encountered in the three depth intervals below the 50-ft depth probably resulted from a leak from tank U-112. The three separate contaminant plumes may have migrated from a single subsurface leak site to intersect the borehole." Figure 6-9 shows the depths of radioactivity from 1980 to 1989 with the Green probe (01) (RPP-7729).

Figure 6-9. Tank U-112 Drywell 60-12-01 (RPP-7729)

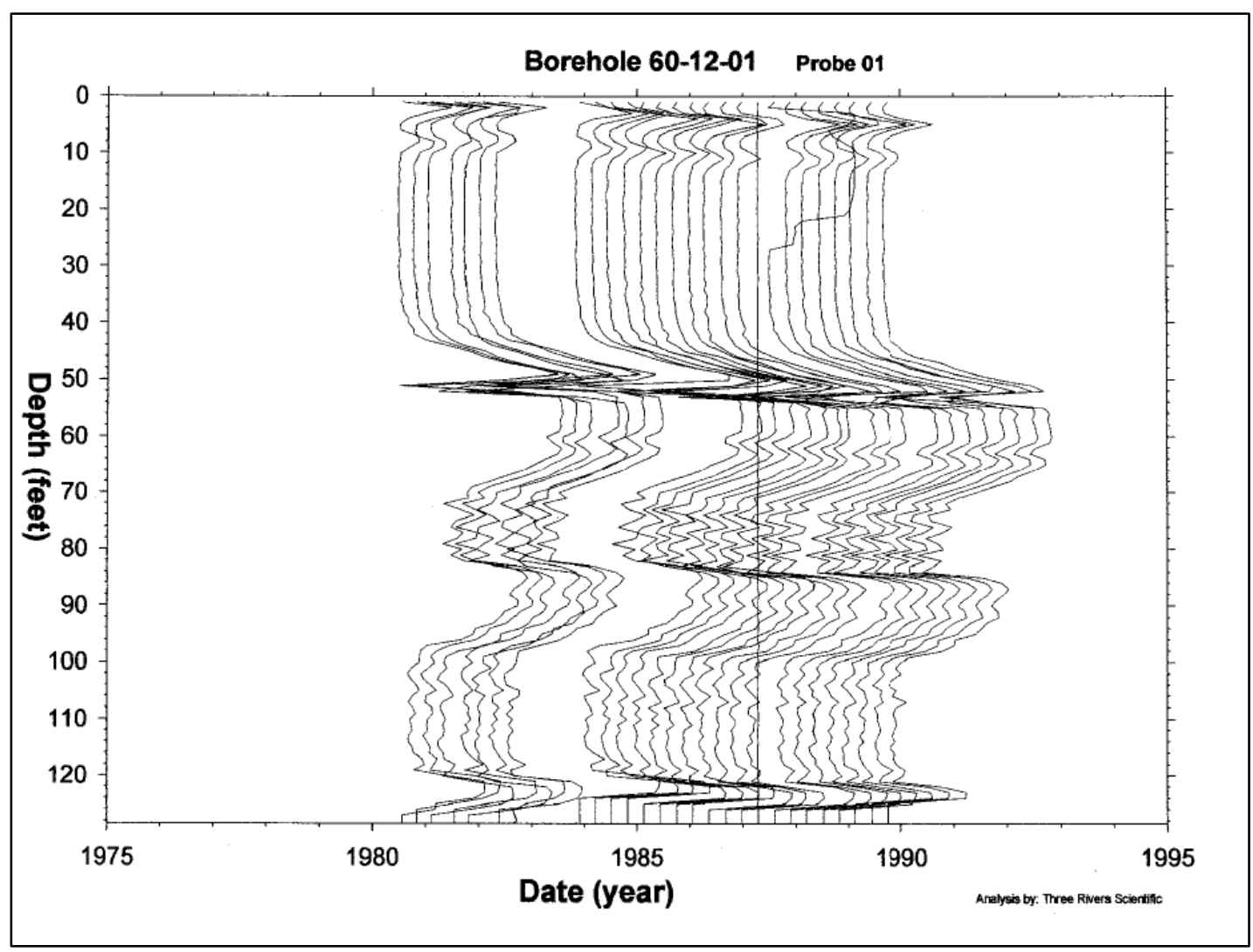

Note: Bottom of the tank footing is $\sim 38$-ft BGS 


\subsubsection{Drywell 60-12-03}

Drywell 60-12-03 is located approximately 9.2-ft from the east side of tank U-112. Drywell 6012-03 was drilled in June 1973 with the first recoverable reading on September 21, 1973 reported as less than values (see Appendix A3). Radioactivity continued to be reported as less than values through October 1986.

In September 1996, Cs-137 was the only man-made radionuclides detected in drywell 60-12-03 (GJ-HAN-41). From the ground surface to 22-ft BGS, at 48-ft BGS, and at the bottom of the drywell, Cs-137 contamination was detected intermittently. Most of the measured Cs-137 ranged between 0.14 and $0.2 \mathrm{pCi} / \mathrm{g}$, the maximum concentration of $2 \mathrm{pCi} / \mathrm{g}$ was measured at the bottom of the drywell (GJ-HAN-41).

Since historical radioactivity in this drywell is very low, and the GJ-HAN-41report indicated low levels of radioactivity, drywell 60-12-03 is not being included as part of the leak location for tank U-112. Figure 6-10 shows the depths of radioactivity from 1975 to 1995 (RPP-7729).

Figure 6-10. Tank U-112 Drywell 60-12-03 (RPP-7729)

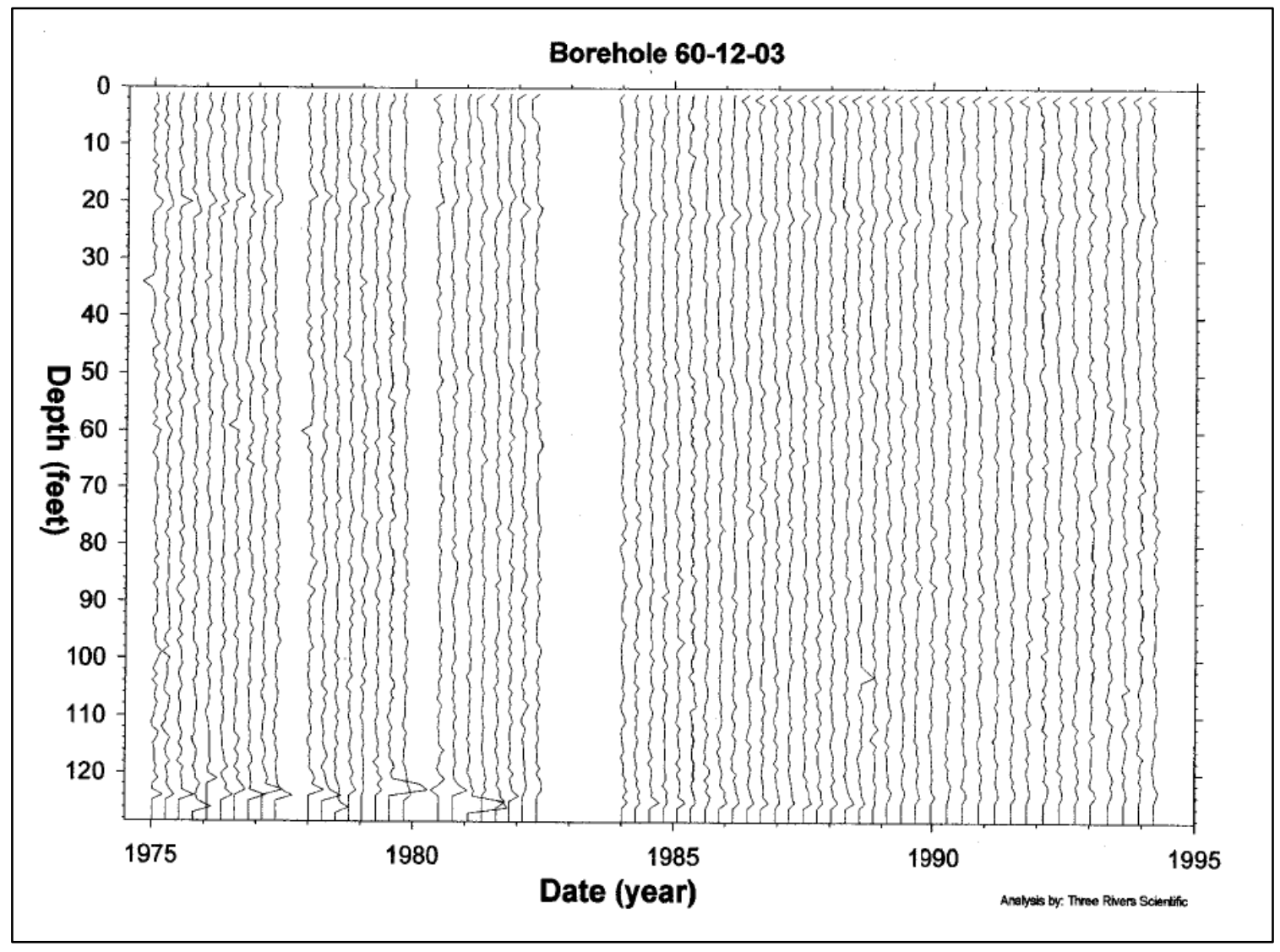

Note: Bottom of the tank footing is $\sim 38$ - $\mathrm{ft}$ BGS 


\subsubsection{Drywell 60-12-05}

Drywell 60-12-05 is located approximately 3.5-ft from the southeast side of tank U-112. Drywell 60-12-05 was drilled in June 1970 with the first recoverable readings reported on September 21, 1973 as less than values (see Appendix A3). Radioactivity continued to be reported as less than values through June 1986.

In September 1996, Cs-137 was the only man-made radionuclides detected in drywell 60-12-05 (GJ-HAN-41). From the ground surface to 11.5-ft BGS, 12.5, 15, 38, 42.5, between 52 and 53$\mathrm{ft}$, and from 49-ft to the bottom of the drywell, Cs-137 contamination was detected intermittently. The maximum concentration of just above $2 \mathrm{pCi} / \mathrm{g}$ was measured at the ground surface and subsurface concentrations typically ranged between 0.14 and $1 \mathrm{pCi} / \mathrm{g}$ (GJ-HAN-41).

Since historical radioactivity in this drywell is very low, and the GJ-HAN-41report indicated low levels of radioactivity, drywell 60-12-05 is not being included as part of the leak location for tank U-112. Figure 6-11 shows the depths of radioactivity from 1975 to 1995 (RPP-7729).

Figure 6-11. Tank U-112 Drywell 60-12-05 (RPP-7729)

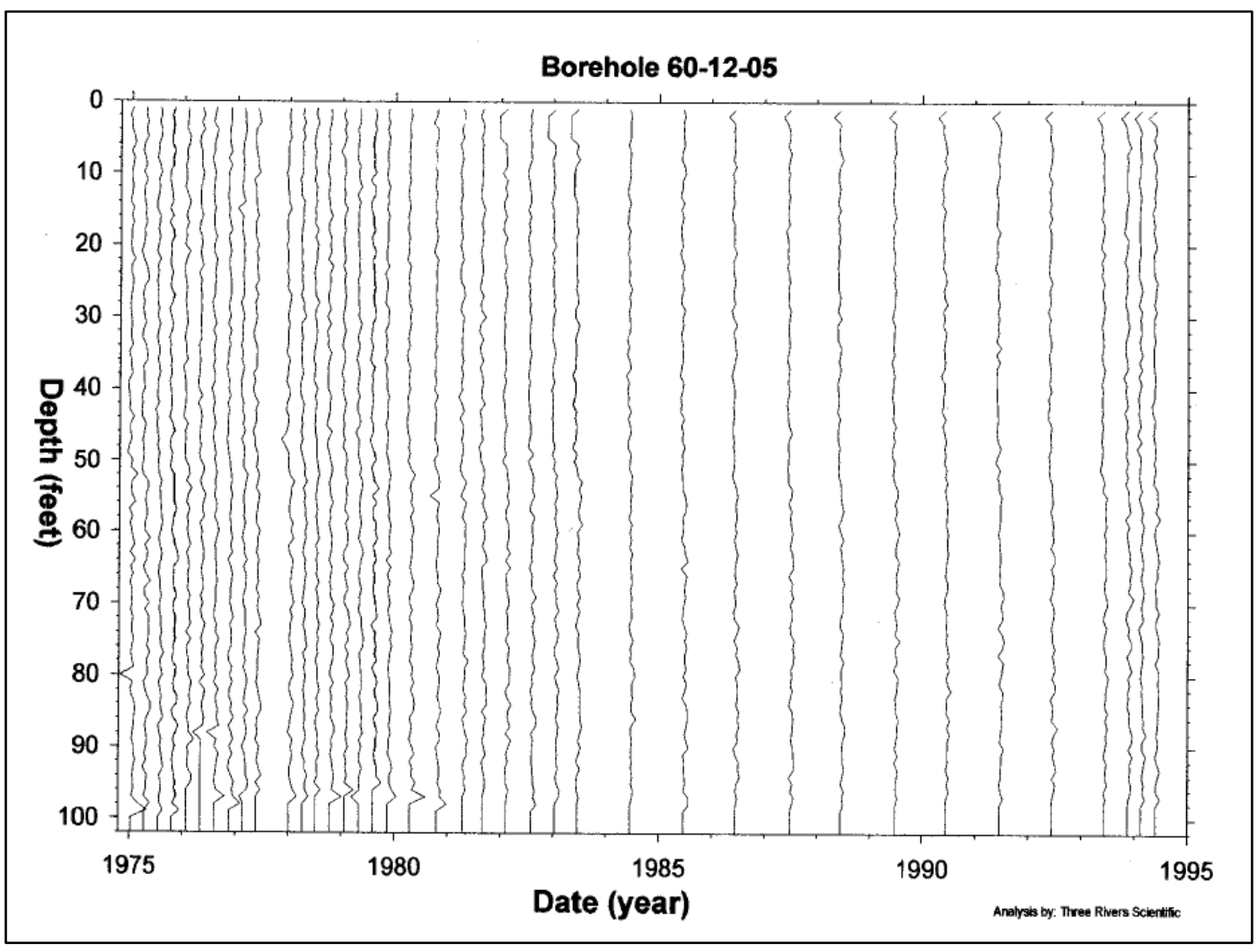

Note: Bottom of the tank footing is $\sim 38$-ft BGS 


\subsubsection{Drywell 60-12-07}

Drywell 60-12-07 is located approximately 4.3-ft from the southwest side of tank U-112. Drywell 60-12-07 was drilled in June 1970 with the first recoverable reading reported on August 23, 1973 as less than values (see Appendix A3). Radioactivity continued to be reported as less than values through June 1986.

In September 1996, Cs-137 was the only man-made radionuclides detected in drywell 60-12-07 (GJ-HAN-41). The maximum Cs-137 concentration was about $11 \mathrm{pCi} / \mathrm{g}$ at the top of the drywell and subsurface concentrations ranged from 0.2 to $1 \mathrm{pCi} / \mathrm{g}$ (GJ-HAN-41).

Since historical radioactivity in this drywell is very low, and the GJ-HAN-41 report indicated low levels of radioactivity, drywell 60-12-07 is not being included as part of the leak location for tank U-112. Figure 6-12 shows the depths of radioactivity from 1975 to 1995 (RPP-7729).

Figure 6-12. Tank U-112 Drywell 60-12-07 (RPP-7729)

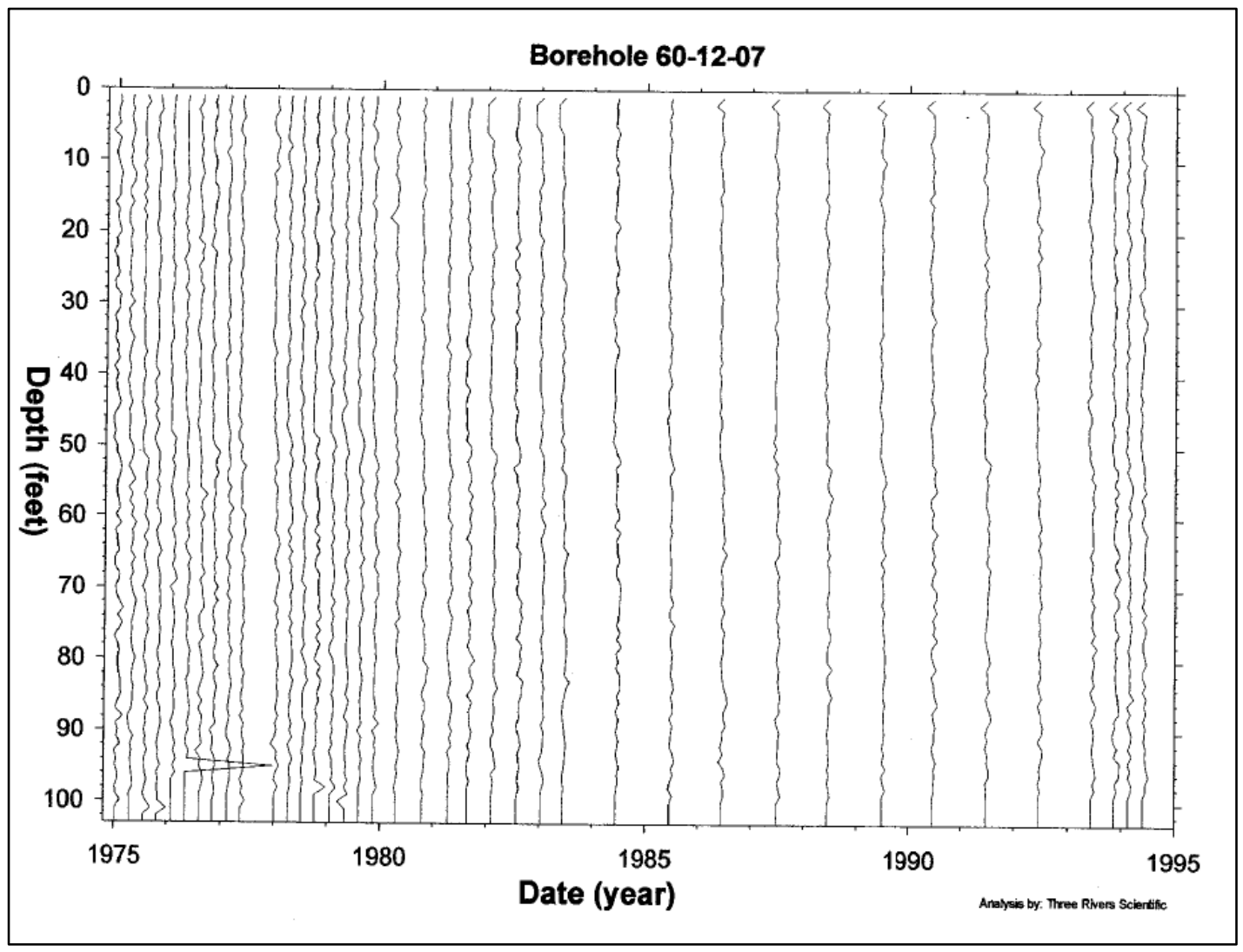

Note: Bottom of the tank footing is $~ 38$-ft BGS 


\subsubsection{Drywell 60-12-10}

Drywell 60-12-10 is located approximately 3.4-ft from the northwest side of tank U-112. Drywell 60-12-10 was drilled in June 1970 with the first recoverable reading reported on August 23, 1973 as less than values (see Appendix A3). Radioactivity continued to be reported as less than values through June 1986.

In September 1996, Cs-137 was the only man-made radionuclides detected in drywell 60-12-10 (GJ-HAN-41). The maximum Cs-137 concentration was about $1 \mathrm{pCi} / \mathrm{g}$ at the top of the drywell and subsurface concentrations ranged from 0.1 to $0.3 \mathrm{pCi} / \mathrm{g}$ (GJ-HAN-41).

Since historical radioactivity in this drywell is very low, and the GJ-HAN-41report indicated low levels of radioactivity, drywell 60-12-10 is not being included as part of the leak location for tank U-112. Figure 6-13 shows the depths of radioactivity from 1975 to 1995 (RPP-7729).

Figure 6-13. Tank U-112 Drywell 60-12-10 (RPP-7729)

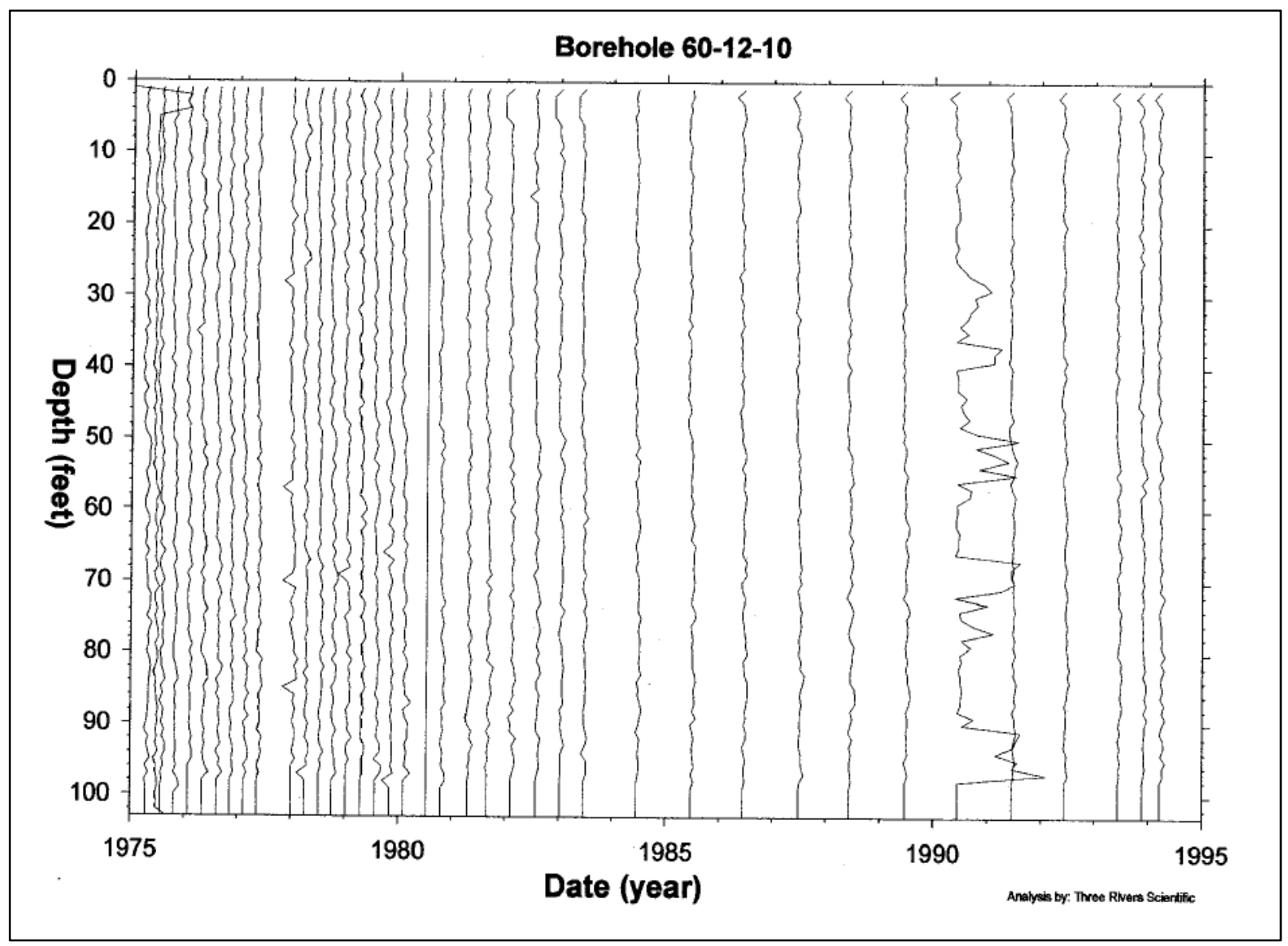

Note: Bottom of the tank footing is $\sim 38$-ft BGS 


\subsubsection{Drywell 60-00-08}

Drywell 60-00-08 is located approximately 38.7-ft from the northwest side of tank U-112. Drywell 60-00-08 was drilled in 1944 with the first recoverable reading on August 22, 1973 reported as less than values (see Appendix A3). Readings continued to be reported as less than values through June 1986.

In September 1996, Cs-137 was the only man-made radionuclides detected in drywell 60-00-08 (GJ-HAN-41). The Cs-137 contamination was detected continuously from the ground surface to the maximum logging depth of 73.5-ft BGS with the maximum concentration of approximately 2 pCi/g detected at 53.5-ft BGS (GJ-HAN-41). Document GJ-HAN-41 states, "Though relatively low in magnitude, the Cs-137 contamination in this borehole is of particular interest because this borehole is positioned to detect contaminant plumes originating from the four smaller auxiliary tanks located in the southwest portion of the U Tank Farm. The trace amounts of Cs-137 contamination in this borehole are not indicative of leakage either from these tanks or from tank U-112."

Since historical radioactivity in this drywell is very low, and the GJ-HAN-41report indicated low levels of radioactivity, drywell 60-00-08 is not being included as part of the leak location for tank U-112. Figure 6-14 shows the depths of radioactivity from 1975 to 1995 (RPP-7729).

Figure 6-14. Tank U-112 Drywell 60-00-08 (RPP-7729)

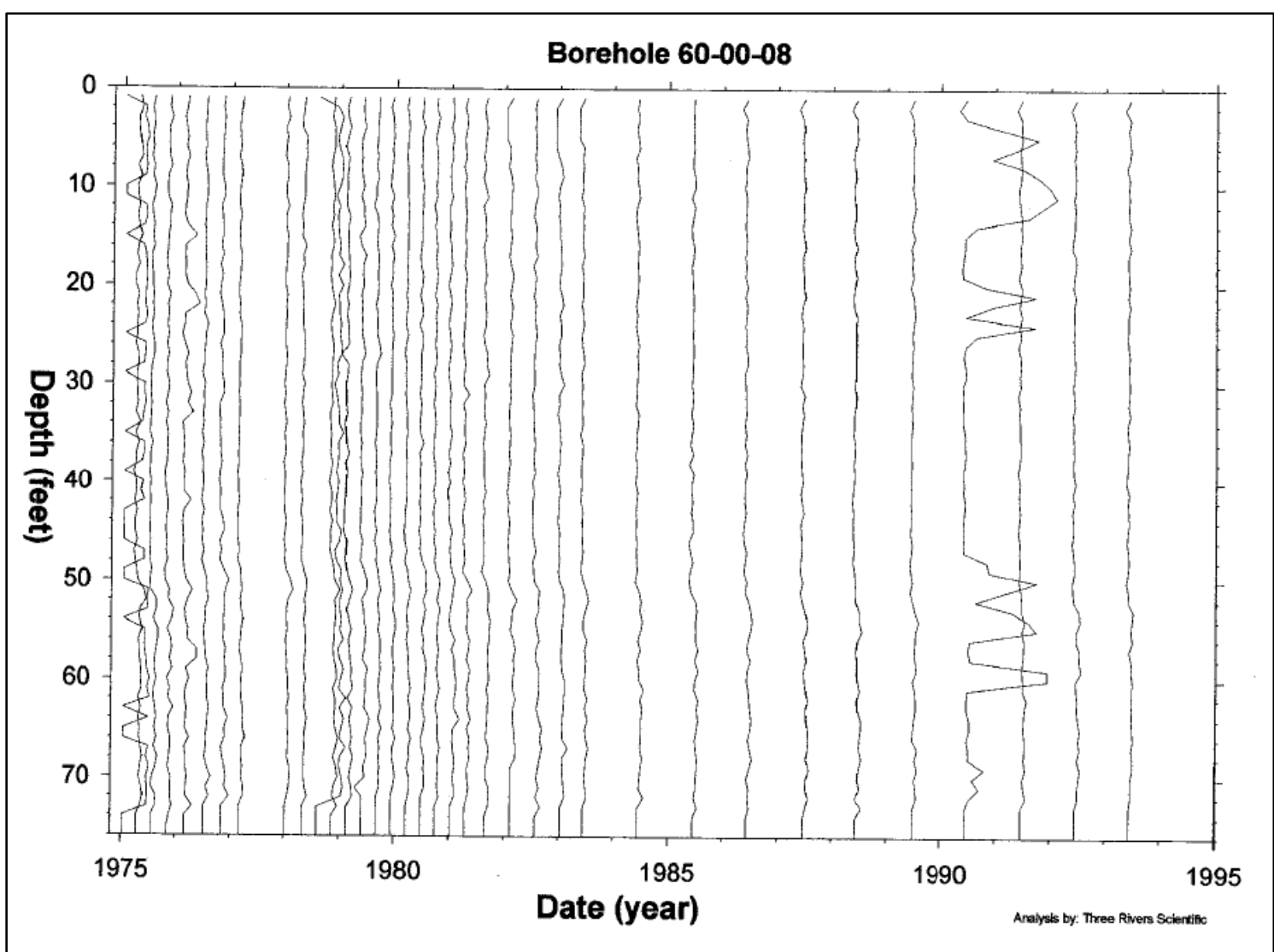

Note: Bottom of the tank footing is $\sim 38$-ft BGS 


\subsubsection{2007 Direct Push}

In 2007, one direct push (C5605) was installed near tank U-112 (near drywell 60-12-01) for moisture and spectral gamma logging (see Figure 6-1).

Results identified elevated moisture contents (25\%) in the 50 to $95-\mathrm{ft}$ BGS range, while only background levels of Cs-137 were recorded throughout the logging (RPP-36007). Therefore, direct push C5605 is not included in the leak location for tank U-112.

\subsubsection{Drywell Summary}

Tank U-112 was first suspected of leaking based on a 3-in liquid level decrease between February 1969 and March 1970; however, the leak could have started as early as December 1964 (see Section 6.4.1). Drywells were installed near tank U-112 in 1970-1974.

Tank U-112 drywells 60-12-03, 60-12-05, 60-12-07, 60-12-10, and 60-00-08 do not indicate any radioactivity associated with a tank U-112 leak. Therefore, these drywells are not included in the leak location for tank U-112.

The first recoverable reading in August 1974 for drywell 60-12-01 indicate radioactivity. A peak of 3,000K cpm was reported in drywell 60-12-01 at 50-ft BGS. Radioactivity declined to approximately $830 \mathrm{~K}$ cpm the next month in September 1974. Readings remained relatively stable through October 1986. It appears the source of the radioactivity detected in this drywell is tank U-112.

Direct push C5605, installed in 2007, reported elevated moisture content in the 50 to $95-\mathrm{ft}$ BGS range and background levels of Cs-137 throughout the logging. Thus, direct push C5605 is not included in the leak location for tank U-112. No laterals were installed under tank U-112.

\subsection{POSSIBLE TANK U-112 LINER LEAK LOCATION(S)}

A liner leak may have penetrated the waterproof membrane at any location or pooled on the waterproof membrane and followed concrete cracks or construction joints to a different location for egress to the soil, including the top of the tank footing.

Tank U-112 had at least one liner leak site based on radioactivity detected in drywell 60-12-01, likely at or near the bottom of the tank. There is also a possibility of a small leak from the cascade inlet line which probably would not have been detected in any nearby drywells during this time.

\subsubsection{Leak Detected in 1964}

Tank U-112 was first reported as leaking due to a 3-in liquid level drop between February 1969 and March 1970 (RHO-CD-896). However, it appears the tank U-112 leak could have started as early as December 1964 due to the liquid level decreasing from December 1964 until March 1970, when the tank was pumped down to minimum heel. The leak was detected in drywell 6012-01 in the northeast portion of the tank when the drywell was drilled in 1974 (see Figure 6-15). No other drywells indicated a tank U-112 leak. 
Figure 6-15. Tank U-112 Possible Leak Location (1964)

Tank inner ring is steel liner; outer ring is outer edge of tank footing

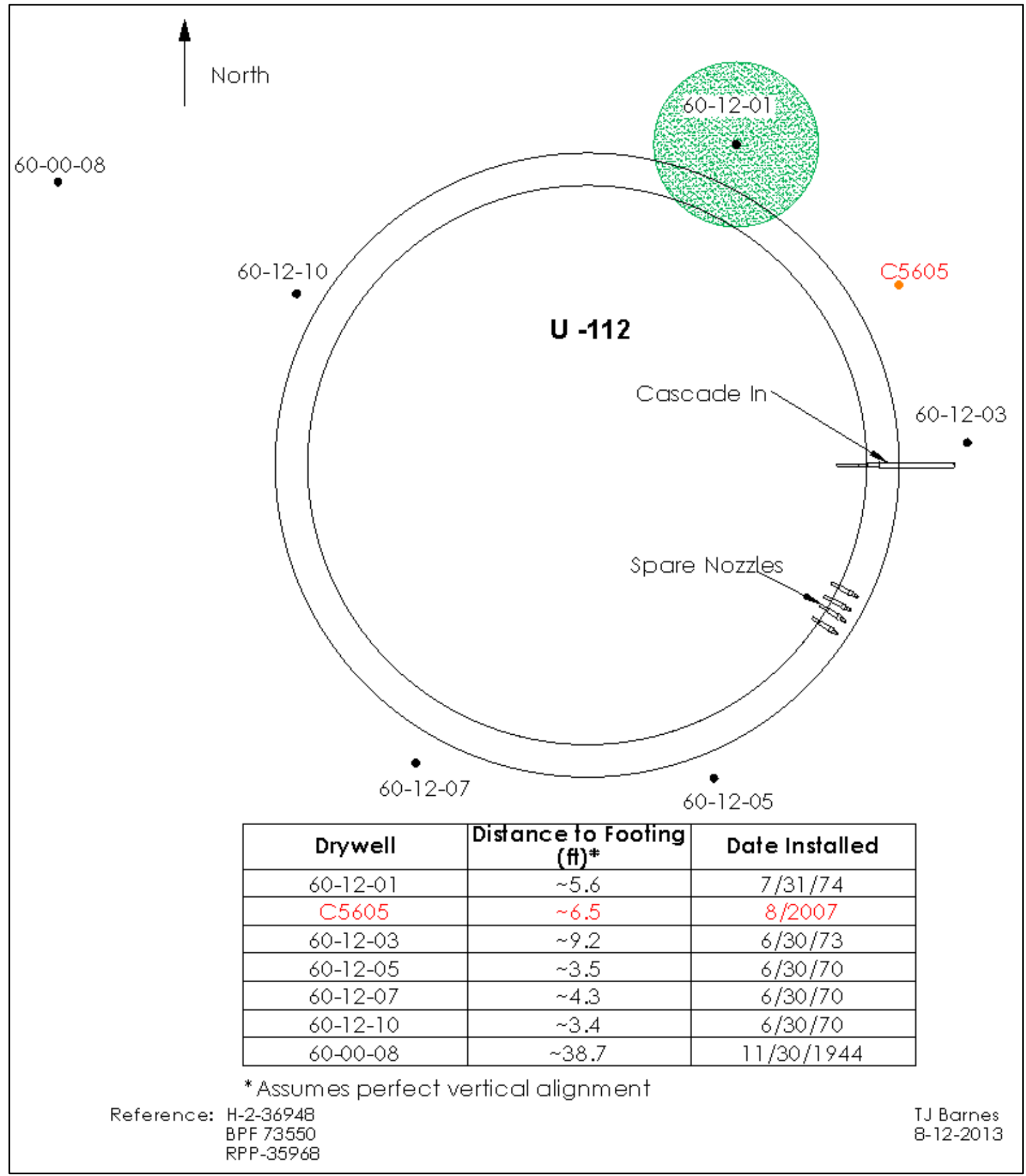


RPP-RPT-54915, Rev. 0

\subsection{POSSIBLE TANK U-112 LINER LEAK CAUSE(S)}

Tank U-112 was evaluated for five conditions known to contribute to a failed liner.

\subsubsection{Tank Design}

The U Farm tank design does not appear to be a factor contributing to a failed liner (see Section 3.1.1).

\subsubsection{Thermal Conditions}

Limited temperature data are available for tank U-112 from October 1947 when the tank was first put into service until 1976. Sludge temperature plots for the one year period between July 1956 and July 1957 (RHO-CD-1172) after receiving some CW with the existing REDOX waste indicated temperatures ranged from $\sim 60^{\circ} \mathrm{F}$ to $\sim 70^{\circ} \mathrm{F}$ with one spike in September 1956 at approximately $170^{\circ} \mathrm{F}$. Tank U-112 did not experience evaporation liquid level decreases like Tank U-110. Tank U-112, the last tank in the tank U-110 cascade would have experienced lower temperatures than those experienced in tank U-110 (see Section 6.4.2).

Thermal shock creates stress both from rapid temperature rise as well as waste-induced high temperatures. Since no records are available during a period of evaporation, it is uncertain what the maximum temperature was in tank U-112 during operation as well as the rate of temperature rise when waste was added. The thermal attributes of the waste and other information (see Section 6.4.2) would indicate that thermal stresses were likely minimal and should not have challenged the tank storage limits.

Temperature requirements in ARH-951 (Limitations for Use of Underground Waste Tanks) issued December 18, 1969 indicated that tank temperatures should be held below $230^{\circ} \mathrm{F}$.

\subsubsection{Chemistry-Corrosion}

Tank U-112 stored REDOX and REDOX/CW waste for $~ 10$ years prior to the 1964 start of decreasing liquid levels at temperatures probably averaging $\sim 100^{\circ} \mathrm{F}$. The REDOX and REDOX/CW waste could have resulted in pitting or SCC under tank U-112 conditions. Other waste types stored in tank U-112 should not have resulted in pitting or SCC.

\subsubsection{Liner Observations}

A review of the available photographs for tank U-112 indicates some possible bottom liner deformation that may have resulted in stressing and weakening of the plates and welds. There is no documentation available indicating a liner bulge was present in tank U-112.

\subsubsection{Tank Construction Temperature}

The U Farm tank liners were constructed between February 1944 and October 1944. Only isolated minimum temperature were experienced during tank construction at or below $18^{\circ} \mathrm{F}$ with day time temperatures between $44^{\circ} \mathrm{F}$ and $57^{\circ} \mathrm{F}$ (see Section 6.3.2). Impact occurrences could have occurred during cold temperatures that may have triggered fissures in the steel liner; 
however, the possibility seems much less than that which might have occurred during construction in other tank farms.

\subsection{TANK U-112 CONCLUSIONS}

Liquid level evidence and drywell radioactivity indicate that the tank U-112 liner leaked in at least one location in the north north-east portion of the tank at or near the tank base.

There are several liner leak cause conditions that were examined and the one that probably caused the tank U-112 liner leak was chemistry-corrosion from pitting and SCC from the storage of REDOX and REDOX/CW waste. Tank U-112 may also have experienced deformation of the bottom liner during construction which may have resulted in stressing and weakening of the plates and welds.

There appears to be very little contribution from other wastes as well as from tank design and construction temperatures. However, some or all of the factors can act serially or together to contribute to tank liner failure. 
RPP-RPT-54915, Rev. 0

APPENDIX A3

TANK U-112 GROSS GAMMA DRYWELL DATA 
RPP-RPT-54915, Rev. 0

Table A3-1. Tank U-112 Drywell Radioactivity (K counts per minute) (August 1974 through October 1986) (SD-WM-TI-356)

\begin{tabular}{|c|c|c|c|c|c|c|c|c|c|c|c|c|}
\hline \multicolumn{3}{|c|}{$60-12-01$} & \multicolumn{2}{|c|}{$60-12-03$} & \multicolumn{2}{|c|}{$60-12-05$} & \multicolumn{2}{|c|}{$60-12-07$} & \multicolumn{2}{|c|}{$60-12-10$} & \multicolumn{2}{|c|}{$60-00-08$} \\
\hline Date & $\begin{array}{c}\text { Peak (K } \\
\text { cpm) }\end{array}$ & $\begin{array}{c}\text { Depth } \\
\text { (ft) }\end{array}$ & Date & $\begin{array}{c}\text { Peak (K } \\
\text { cpm) }\end{array}$ & Date & $\begin{array}{c}\text { Peak (K } \\
\text { cpm) }\end{array}$ & Date & $\begin{array}{c}\text { Peak (K } \\
\text { cpm) }\end{array}$ & Date & $\begin{array}{c}\text { Peak (K } \\
\text { cpm) }\end{array}$ & Date & $\begin{array}{c}\text { Peak (K } \\
\text { cpm) }\end{array}$ \\
\hline $8 / 22 / 1974$ & 3000 & 50 & $9 / 21 / 1973$ & $<12$ & $9 / 21 / 1973$ & $<12$ & $8 / 23 / 1973$ & $<12$ & $8 / 23 / 1973$ & $<12$ & $8 / 22 / 1973$ & $<12$ \\
\hline $9 / 12 / 1974$ & 831.5 & 53 & $4 / 12 / 1974$ & $<12$ & 4/12/1974 & $<12$ & $4 / 12 / 1974$ & $<12$ & 7/18/1974 & $<3$ & $6 / 6 / 1974$ & $<12$ \\
\hline \multicolumn{3}{|c|}{$\mathrm{N} / \mathrm{A}^{1}$} & $6 / 8 / 1974$ & $<3$ & $6 / 8 / 1974$ & $<3$ & $6 / 8 / 1974$ & $<3$ & \multicolumn{2}{|c|}{$\mathrm{N} / \mathrm{A}^{1}$} & $7 / 1 / 1974$ & $<3$ \\
\hline \multicolumn{3}{|c|}{ N/A ${ }^{1}$} & $2 / 20 / 1974$ & $<3$ & \multicolumn{2}{|c|}{ N/A ${ }^{1}$} & \multicolumn{2}{|c|}{ N/A ${ }^{1}$} & \multicolumn{2}{|c|}{ N/A ${ }^{1}$} & \multicolumn{2}{|c|}{$\mathrm{N}^{\prime} \mathrm{A}^{1}$} \\
\hline $2 / 13 / 1975$ & 782.1 & 52 & \multicolumn{2}{|c|}{ N/A ${ }^{1}$} & $1 / 24 / 1975$ & $<3$ & $2 / 5 / 1975$ & $<3$ & $2 / 5 / 1975$ & $<3$ & $1 / 24 / 1975$ & $<3$ \\
\hline $8 / 6 / 1975$ & 794.9 & 51 & $8 / 11 / 1975$ & $<3$ & $8 / 6 / 1975$ & $<3$ & $8 / 6 / 1975$ & $<3$ & \multicolumn{2}{|c|}{$\mathrm{N} / \mathrm{A}^{1}$} & $8 / 5 / 1975$ & $<3$ \\
\hline $12 / 30 / 1975$ & 799.7 & 52 & $12 / 30 / 1975$ & $<3$ & $12 / 30 / 1975$ & $<3$ & $12 / 30 / 1975$ & $<3$ & $11 / 12 / 1975$ & $<3$ & \multicolumn{2}{|c|}{$\mathrm{N}^{\prime} \mathrm{A}^{1}$} \\
\hline \multicolumn{3}{|c|}{$\mathrm{N} / \mathrm{A}^{1}$} & \multicolumn{2}{|c|}{$\mathrm{N} / \mathrm{A}^{1}$} & \multicolumn{2}{|c|}{$\mathrm{N}^{\prime} \mathrm{A}^{1}$} & \multicolumn{2}{|c|}{$\mathrm{N} / \mathrm{A}^{1}$} & \multicolumn{2}{|c|}{$\mathrm{N} / \mathrm{A}^{1}$} & $1 / 7 / 1976$ & $<3$ \\
\hline $5 / 11 / 1976$ & 785 & 50 & $5 / 11 / 1976$ & $<3$ & $5 / 11 / 1976$ & $<3$ & $5 / 11 / 1976$ & $<3$ & \multicolumn{2}{|c|}{$\mathrm{N} / \mathrm{A}^{1}$} & $5 / 5 / 1976$ & $<3$ \\
\hline $10 / 19 / 1976$ & 978.1 & 50 & \multicolumn{2}{|c|}{ N/A ${ }^{1}$} & \multicolumn{2}{|c|}{$\mathrm{N}^{\prime} \mathrm{A}^{1}$} & \multicolumn{2}{|c|}{$\mathrm{N}^{\prime} \mathrm{A}^{1}$} & $11 / 10 / 1976$ & $<3$ & \multicolumn{2}{|c|}{$\mathrm{N}^{\prime} \mathrm{A}^{1}$} \\
\hline $3 / 1 / 1977$ & 932.9 & 50 & $1 / 5 / 1977$ & $<3$ & $1 / 5 / 1977$ & $<3$ & $1 / 5 / 1977$ & $<3$ & $\mathrm{~N} / \mathrm{A}$ & & $1 / 5 / 1977$ & $<3$ \\
\hline $8 / 2 / 1977$ & 902.6 & 50 & \multicolumn{2}{|c|}{ N/A ${ }^{1}$} & \multicolumn{2}{|c|}{$\mathrm{N}^{\prime} \mathrm{A}^{1}$} & \multicolumn{2}{|c|}{$\mathrm{N}^{\prime} \mathrm{A}^{1}$} & \multicolumn{2}{|c|}{$\mathrm{N}^{\prime} \mathrm{A}^{1}$} & $\mathrm{~N} / \mathrm{t}$ & \\
\hline $11 / 22 / 1977$ & 843.1 & 51 & $11 / 23 / 1977$ & $<3$ & $11 / 22 / 1977$ & $<3$ & $11 / 22 / 1977$ & $<3$ & 11/15/1977 & $<3$ & $11 / 1 / 1977$ & $<3$ \\
\hline $3 / 7 / 1978$ & 822.3 & 51 & N/A & & $\mathrm{N} / \mathrm{A}$ & & $\mathrm{N} /$ & & $\mathrm{N} / \mathrm{A}$ & & $\mathrm{N} / \mathrm{t}$ & \\
\hline $3 / 14 / 1978$ & 338.8 & 50 & N/A & & $\mathrm{N} / \mathrm{A}$ & & $\mathrm{N} / \mathrm{t}$ & & $\mathrm{N} / \mathrm{A}$ & & $\mathrm{N} / \mathrm{H}$ & \\
\hline $11 / 6 / 1978$ & 262.3 & 50 & $11 / 16 / 1978$ & $<3$ & $11 / 16 / 1978$ & $<3$ & $11 / 16 / 1978$ & $<3$ & $11 / 2 / 1978$ & $<3$ & $11 / 15 / 1978$ & $<3$ \\
\hline $11 / 5 / 1979$ & 327 & 49 & $11 / 1 / 1979$ & $<3$ & $11 / 1 / 1979$ & $<3$ & $11 / 1 / 1979$ & $<3$ & $11 / 1 / 1979$ & $<3$ & $10 / 31 / 1979$ & $<3$ \\
\hline $11 / 3 / 1980$ & 304 & 51 & $11 / 13 / 1980$ & $<3$ & $10 / 16 / 1980$ & $<3$ & $\mathrm{~N} / \mathrm{t}$ & & $10 / 16 / 1980$ & $<3$ & $11 / 13 / 1980$ & $<3$ \\
\hline $12 / 21 / 1981$ & 278.9 & 51 & 11/19/1981 & $<3$ & 11/19/1981 & $<3$ & 11/19/1981 & $<3$ & 11/19/1981 & $<3$ & $11 / 19 / 1981$ & $<3$ \\
\hline $12 / 6 / 1982$ & 264.5 & 52 & $11 / 3 / 1982$ & $<3$ & $10 / 21 / 1982$ & $<3$ & $10 / 21 / 1982$ & $<3$ & $10 / 21 / 1982$ & $<3$ & $10 / 21 / 1982$ & $<3$ \\
\hline $11 / 28 / 1983$ & 341.5 & 51 & $11 / 22 / 1983$ & $<3$ & $6 / 15 / 1983$ & $<3$ & $6 / 15 / 1983$ & $<3$ & $6 / 15 / 1983$ & $<3$ & $6 / 15 / 1983$ & $<3$ \\
\hline $10 / 29 / 1984$ & 196.7 & 52 & $10 / 24 / 1984$ & $<3$ & $6 / 13 / 1984$ & $<3$ & $6 / 13 / 1984$ & $<3$ & $6 / 13 / 1984$ & $<3$ & $6 / 13 / 1984$ & $<3$ \\
\hline $11 / 26 / 1985$ & 290 & 53 & $11 / 20 / 1985$ & $<3$ & $6 / 19 / 1985$ & $<3$ & $6 / 19 / 1985$ & $<3$ & $6 / 19 / 1985$ & $<3$ & $6 / 19 / 1985$ & $<3$ \\
\hline $10 / 29 / 1986$ & 334.3 & 53 & $10 / 24 / 1986$ & $<3$ & $6 / 10 / 1986$ & $<3$ & $6 / 10 / 1986$ & $<3$ & $6 / 10 / 1986$ & $<3$ & $6 / 10 / 1986$ & $<3$ \\
\hline
\end{tabular}


RPP-RPT-54915, Rev. 0

\subsection{CONCLUSIONS}

Liner leaks probably occurred at or near the base of all three leaking $U$ Farm tanks. The bulging bottom liner of tank U-104 and the depth of radioactivity detected in tank U-104, U-110, and tank U-112 drywells all point to a liner leak near the bottom of the tank.

There are several liner leak cause conditions that were examined for tanks U-104, U-110, and U112 which include tank design, construction conditions, thermal conditions, and chemistrycorrosion. Thermal conditions appear to be the most likely cause of the tank U-104 liner leak. Chemistry-corrosion, relating to the storage of REDOX waste appears to be the most likely cause of the leak(s) for tanks U-110 and U-112 and possible laboratory wastes for tank U-110. REDOX waste at elevated temperatures could have created an environment conducive to pitting and SCC. Tank U-112 may also have experienced deformation of the bottom liner during construction possibly creating stresses and weakening of the plates and welds.

Tank U-104 experienced a 5-ft bulge in the bottom liner which was detected while completing sluicing of the second batch of MW. The liner bulge was probably the result of temperature rate of rise especially during the second filling of the tank with MW. This could have set up a situation where vapor pressure under the bottom liner was greater than the hydrostatic pressure. The bulge probably weakened the bottom liner to the point of failure which was confirmed by subsequent leak testing and detection of drywell radioactivity.

Both tank U-110 and U-112 experienced liner failures that were detected by a liquid level decrease and subsequently confirmed by the detection of drywell radioactivity in one of the drywells surrounding each of the tanks. Corrosion may have been a factor in each case as both tank U-110 and U-112 stored REDOX waste which is conducive to pitting and SCC. Tank U110 also stored several hundred thousand gallons of unknown laboratory waste which may have influenced corrosion. Tank U-112 may also have experienced deformation of the bottom liner during construction which may have resulted in stressing and weakening of the plates and welds.

There appears to be very little contribution from tank design and construction temperatures. However, some or all of the factors can act serially or together to contribute to tank failure.

Basic information on the leaking U Farm tanks and the U Farm sound tanks are listed separately in Table 7-1 and Table 7-2. The information was reviewed to identify any differences between leaking and sound tanks related to liner failure. A number of the sound tanks contained REDOX waste under similar conditions that may have caused corrosion that resulted in the tank U-110 and tank U-112 liner leaks.

The sound tank U-111 is one of the tanks that stored REDOX waste. It is in the curious position of being the second tank of the three tank cascade from tank U-110 to tank U-112 both of which are leaking tanks. This would seem to put into question the postulated REDOX waste corrosion effect unless there was some other unknown factor influencing corrosion rate or other conditions such as tank U-112 with the possibility of bottom liner stresses caused by poor construction of the bottom liner. There doesn't seem to be any of the basic information that stands out as the reason sound tanks did not experience liner leaks. 
RPP-RPT-54915, Rev. 0

Table 7-1. U Farm Leaking Tanks

\begin{tabular}{|c|c|c|c|c|c|c|c|}
\hline \multirow{2}{*}{$\begin{array}{c}\text { Leaking } \\
\text { Tank }\end{array}$} & \multicolumn{2}{|c|}{ Waste Details } & \multicolumn{2}{|c|}{ Leak Status } & \multicolumn{2}{|c|}{ R Waste Storage } & \multirow{2}{*}{$\begin{array}{c}\text { Thermal Conditions } \\
\text { Estimated Max Temp }\end{array}$} \\
\hline & First Filled & Waste Type & Leak Detected & Indication of leak & $\begin{array}{c}\text { Stored R } \\
\text { Waste }\end{array}$ & $\begin{array}{c}\text { R Only Storage } \\
\text { Length }\end{array}$ & \\
\hline U-104 & July 1947 & MW, water & July 1956 & Drywells & No & - & $<180^{\circ} \mathrm{F}$ \\
\hline U-110 & July 1946 & $1 \mathrm{C} / \mathrm{CW}, \mathrm{R}, \mathrm{CW}, \mathrm{LW}$ & July 1975 & LL decrease, Drywells & Yes & $\sim 1.5$ years & $>180^{\circ} \mathrm{F}$ \\
\hline U-112 & October 1947 & $1 \mathrm{C} / \mathrm{CW}, \mathrm{R}, \mathrm{CW}$ & December 1964 & LL decrease, Drywells & Yes & $\sim 10$ years $^{1}$ & $<120^{\circ} \mathrm{F}$ \\
\hline
\end{tabular}

Notes: $\quad$ Waste Types: MW: Metal Waste; TBP: Tri-butyl phosphate waste; CW: coating waste; R: REDOX HLW; 1C: First-cycle decontamination waste; LW: laboratory waste

1. Stored $\mathrm{R}$ waste for 10 years until the leak was first detected (total storage length was $\sim 16$ years)

Table 7-2. U Farm Sound Tanks

\begin{tabular}{|c|c|c|c|c|c|c|c|}
\hline \multirow{2}{*}{$\begin{array}{c}\text { Sound } \\
\text { Tank }\end{array}$} & \multicolumn{2}{|c|}{ Waste Details } & \multicolumn{2}{|c|}{ Leak Status } & \multicolumn{2}{|c|}{ R Waste Storage ${ }^{6}$} & \multirow{2}{*}{$\begin{array}{c}\text { Thermal Conditions } \\
\text { Estimated Max Temp }\end{array}$} \\
\hline & First Filled $^{1}$ & Waste Type & Leak Integrity Classification ${ }^{2}$ & $\begin{array}{l}\text { Basis for Formal } \\
\text { Leak Assessment }\end{array}$ & $\begin{array}{l}\text { Stored R } \\
\text { Waste }\end{array}$ & $\begin{array}{l}\text { R Only Storage } \\
\text { Length }\end{array}$ & \\
\hline U-101 & February 1946 & MW, R & $\begin{array}{l}\text { “Confirmed leaker" but TFC- } \\
\text { ENG-CHEM-D-42 }\end{array}$ & $\begin{array}{l}\text { Direct push logging } \\
\text { and samples } \\
\text { recommended } \\
\end{array}$ & Yes & $\sim 3$ years & $92^{\circ} \mathrm{F}$ \\
\hline U-102 & June 1946 & MW, R, NCPLX, EB, Resid. & Sound & - & Yes & $\sim 18$ years & $134^{\circ} \mathrm{F}$ \\
\hline $\mathrm{U}-\mathbf{1 0 3}$ & February 1947 & MW, R, PNF, EB, Evap. & Sound & - & Yes & $\sim 18$ years & $132^{\circ} \mathrm{F}$ \\
\hline $\mathrm{U}-105$ & December 1947 & R, CW, MW, CPLX, EB, Resid. & Sound & - & Yes & $\sim 19$ years & $146^{\circ} \mathrm{F}$ \\
\hline U-106 & May 1948 & MW, R, CCPLX, Resid., Evap. & Sound & - & Yes & $\sim 18$ years & $122^{\circ} \mathrm{F}$ \\
\hline U-107 & September 1948 & $\begin{array}{l}\text { CW, MW, EB, BNW, N, DW, } \\
\text { CPLX, Evap., NCPLX }\end{array}$ & Sound & - & No & - & $122^{\circ} \mathrm{F}$ \\
\hline U-108 & January 1949 & $\begin{array}{c}\mathrm{CW}, \mathrm{MW}, \mathrm{EB}, \mathrm{N}, \mathrm{BNW}, \mathrm{DW}, \\
\text { PNF, Resid., EB }\end{array}$ & Sound & - & No & - & $130^{\circ} \mathrm{F}$ \\
\hline U-109 & March 1949 & CW, MW, EB, PNF, Resid. & Sound & - & $\mathrm{Yes}^{4}$ & $\sim 1$ year & $120^{\circ} \mathrm{F}$ \\
\hline $\mathrm{U}-111$ & April 1947 & 1C, R, CPLX, PNF, EB & Sound & - & Yes & $\sim 20$ years $^{5}$ & $130^{\circ} \mathrm{F}$ \\
\hline
\end{tabular}

Notes: $\quad$ Waste Types: TBP: Tri-butyl phosphate waste; 1C: First-cycle decontamination waste; CW: coating waste; MW: metal waste; EB: Evaporator bottoms; R: REDOX HLW; Evap:

Evaporator feed (post 1976); NCPLX: Non-Complexed waste; Resid: Residual evaporator liquor; PNF: Partial neutralization feed; CPLX: complexed waste; DW: decontamination waste

1. Reference: Tank Waste Information Network System

2. Reference: RPP-RPT-50097, Rev. 0, Hanford 241-U Farm Leak Inventory Assessment Report.

3. Reference: WHC-SD-WM-TI-591, Rev. 0, Maximum Surface Level and Temperature Histories for Hanford Waste Tank

4. Received $\mathrm{R}$ waste from $\mathrm{U}-112$ which was mixed with $\mathrm{CW}$ and $\mathrm{EB}$

5. 14 years were a mixed waste of $\mathrm{R} / \mathrm{CW}, 6$ years storage of only $\mathrm{R}$

6. Reference: WHC-MR-0132, A History of the 200 Area Tank Farms 
RPP-RPT-54915, Rev. 0

\subsection{REFERENCES}

ARH-951, 1969, Limitations for Use of Underground Waste Tanks, Richland, Washington.

ARH-1601, 1974, Specifications and Standards for the Operation of Radioactive Waste Tank Farms and Associated Facilities, Atlantic Richfield Hanford Company, Richland, Washington.

ARH-CD-222, 1974, Characterization of the Effects of Diatomaceous Earth Additions to Hanford Wastes, Atlantic Richfield Hanford Company, Richland, Washington.

ARH-CD-336B, 1975, Production and Waste Management Division Waste Status Summary April 1, 1975 through June 30, 1975, Atlantic Richfield Hanford Company, Richland, Washington.

ARH-CD-336C, 1975, Production and Waste Management Division Waste Status Summary July 1, 1975 through September 30, 1975, Atlantic Richfield Hanford Company, Richland, Washington.

ARH-R-43, 1970, Management of Radioactive Wastes Stored in Underground Tanks at Hanford, Rev. 2, Atlantic Richfield Hanford Company, Richland, Washington.

ASTM A7-39, 1939, American Society for Testing and Materials, Standard Specifications for Steel for Bridges and Buildings

ASTM A283, 1946, American Society for Testing and Materials, Standard Specification for Low and Intermediate Tensile Strength Carbon Steel Plates

BPF-73550, 1944, Specification for Construction of Composite Storage Tanks (B, $C, T$, and $U$ Tank Farms), Hanford Engineer Works, Richland, Washington.

DS-103174, 1978, Data Sheet Salt Well Transfer: Tk-112U to Tk-109U, Rockwell Hanford Operations, Richland, Washington.

DSI, 1961, “104-U Tank” (internal memorandum from G. L. Hanson to M. K. Harmon, March 31), Atlantic Richfield Hanford Company, Richland, Washington.

EM-TF-040.9a, 1956, "Inspection of Waste Storage Tank 241-U-104” (internal memorandum from E. F. Smith and F. H. Shadel to H. F. Peterson, August 7; attachment to internal letter 65431-79-002, "Tank 271-U-111, Imperfections on the Inside Surface of the Reinforced Concrete Dome" from F. R. Vollert to C. R. Carter, May 17, 1979), Rockwell International, Richland, Washington.

GJ-HAN-33, 1996, Vadose Zone Monitoring Project at the Hanford Tank Farms Tank Summary Data Report for Tank U-104, U.S. Department of Energy Grand Junction Projects Office, Grand Junction, Colorado. 
GJ-HAN-39, 1996, Vadose Zone Monitoring Project at the Hanford Tank Farms Tank Summary Data Report for Tank U-110, U.S. Department of Energy Grand Junction Projects Office, Grand Junction, Colorado.

GJ-HAN-41, 1996, Vadose Zone Monitoring Project at the Hanford Tank Farms Tank Summary Data Report for Tank U-112, U.S. Department of Energy Grand Junction Projects Office, Grand Junction, Colorado.

GJPO-HAN-8, Vadose Zone Characterization Project at the Hanford Tank Farms U Tank Farm Report, U.S. Department of Energy Grand Junction Projects Office, Grand Junction, Colorado.

H-2-2257, 1962, Conductor Reel for Liquid Level Measurement, General Electric Company, Richland, Washington.

H-2-36948, 2007, Wells in 241-U Farm As-Built, WRPS, Richland, Washington.

HNF-3018, 1998, Single-Shell Tank Sluicing History and Failure Frequency, COGEMA Engineering Corporation, Richland, Washington.

HNF-3136, 1998, Analysis Techniques and Monitoring Results, 241-SX Drywell Surveillance Logs, Lockheed Martin Hanford Corporation, Richland, Washington.

HNF-EP-0182, 2013, Waste Tank Summary Report for Month Ending April 30, 2013, Rev. 301, CH2M Hill Hanford Group, Inc., Richland, Washington.

HW-1946, 1943, Specifications for Composite Storage Tanks - Buildings \#241 at Hanford Engineering Works, General Electric Company, Richland, Washington.

HW-7-4542-DEL, 1946, Hanford Engineer Works Monthly Report July 1946, General Electric Company, Richland, Washington.

HW-7-6184-DEL, 1947, Hanford Works Monthly Report April 1947, General Electric Company, Richland, Washington.

HW-7283-DEL, 1947, Hanford Engineer Works Monthly Report July 1947, General Electric Company, Richland, Washington.

HW-8438-DEL, 1947, Hanford Works Monthly Report December 1947, General Electric Company, Richland, Washington.

HW-10166-DEL, 1948, Hanford Works Monthly Report May 1948, General Electric Company, Richland, Washington.

HW-10475-C-DEL, 1944, Hanford Technical Manual Section C, General Electric Company, Richland Washington 
HW-11226-DEL, 1948, Hanford Works Monthly Report September 1948, General Electric Company, Richland, Washington.

HW-14946, 1949, A Survey of Corrosion Data and Construction Details, 200 Area Waste Storage Tanks, General Electric Company, Richland, Washington.

HW-20742, 1951, Loss of Depleted Metal Waste Supernate to Soil, General Electric Company, Richland, Washington.

HW-27838, 1952, Waste Status Summary Period: April, May, and June 1952, General Electric Company, Richland, Washington.

HW-30851, 1954, Waste Status Summary January 1954, General Electric Company, Richland, Washington.

HW-31811, 1954, Separations Section Waste - Status Summary April 30, 1954, General Electric Company, Richland, Washington.

HW-33544, 1954, Separations Section, Waste-Status Summary for October 1954, General Electric Company, Richland, Washington.

HW-33904, 1954, Separations Section, Waste-Status Summary for November 1954, General Electric Company, Richland, Washington.

HW-43490, 1956, Separations Section Waste - Status Summary for May, 1956, General Electric Company, Richland, Washington.

HW-44024-RD, 1956, TBP Plant and Tank Farm Weekly Summary - Process Unit-6-29-56 thru 8-31-56, General Electric Company, Richland, Washington.

HW-44860, 1956, Separations Section, Waste - Status Summary July 1956, General Electric Company, Richland, Washington.

HW-45115 H, 1956, Separations Technology Section Monthly Report - August, 1956, General Electric Company, Richland, Washington.

HW-48144, 1957, Chemical Processing Department Waste - Status Summary January 1, 1957 January 31, 1957, General Electric Company, Richland, Washington.

HW-51026, 1957, Leak Detection - Underground Storage Tanks, General Electric Company, Richland, Washington.

LET-082172, 1972, “Maximum Operating Levels and Cascade Levels in 200-West Area Tank Farms" (internal letter from H.N. Raymond to C.J. Francis, August 21).

LET-72730-80-097, 1980, "Review of Classification of Six Hanford Single-Shell "Questionable Integrity (QI)” Tanks” (internal letter from W.M. Lindsay to W.W. Schulz September 16). 
Oblath, S. B. and J. W. Congdon, 1987, "Inhibiting Localized Corrosion during Storage of Dilute SRP Waste", Waste Management '87, Volume 1, Tucson, AZ: Arizona Board of Regents: 599-602.

OSD-T-151-00007, 2012, Operating Specifications for the Double-Shell Storage Tanks, Rev. 10, Washington River Protection Solutions, LLC., Richland, Washington.

OSD-T-151-00017, 1983, Operating Specifications for the Aging Waste Operations in Tank Farms 241-AY and 241-AZ, Rev. B-0, Rockwell Hanford Operations, Richland, Washington.

OR 75-67, 1975, Liquid Level Decrease in Tank 110-U, Atlantic Richfield Hanford Company, Richland, Washington.

PNL-5488, 1985, Prediction Equations for Corrosion Rates of A-537 and A-516 Steels in Double Shell Flurry, Pacific Northwest Laboratory, Richland, Washington.

PNNL-13571, 2001, Expert Panel Recommendations for Hanford Double-Shell Tank Life Extension, Pacific Northwest National Laboratory, Richland, Washington.

RHO-CD-896, 1980, Review of Classification of Nine Hanford Single-Shell "Questionable Integrity” Tanks, Rockwell Hanford Operations, Richland, Washington.

RHO-CD-1172, 1981, Survey of the Single-Shell Tank Thermal Histories, Rockwell Hanford Operations, Richland, Washington.

RHO-ST-34, 1981, A Scientific Basis for Establishing Drywell-Monitoring Frequencies, Rockwell Hanford Operations, Richland, Washington.

RHO-RE-EV-4P, 1982, Supporting Information for the Scientific Basis for Establishing Drywell Monitoring Frequencies, Rockwell Hanford Operations, Richland, Washington.

RPP-7729, 2001, Analysis and Summary Report of Historical Dry Well Gamma Logs for the 241-U Tank Farm - 200 West, Rev. 0, CH2M HILL Hanford Group, Inc., Richland, Washington.

RPP-8321, 2001, Analysis and Summary Report of Historical Drywell Gamma Logs for the 241C Tank Farm 200 East Area, CH2M HILL Hanford Group Inc., Richland, Washington.

RPP-20820, 2004, Waste Retrieval Leak Evaluation Report: Single-Shell Tanks, Rev. 0, CH2M HILL Hanford Group Inc., Richland, Washington.

RPP-32681, 2011, Process to Assess Tank Farm Leaks in Support of Retrieval and Closure Planning, Rev. 1, Washington River Protection Solutions, LLC., Richland, Washington.

RPP-36007, 2007, Small Diameter Geophysical Logging in the 241-U Tank Farm, Rev. 0, CH2M HILL Hanford Group, Inc., Richland, Washington. 
RPP-ASMT-53793, 2012, Tank 241-AY-102 Leak Assessment Report, Rev. 0, Washington River Protection Solutions, LLC., Richland, Washington.

RPP-RPT-33306, 2008, IQRPE Integrity Assessment Report for the 242-A Evaporator Tank System, Rev. 0A, CH2M HILL Hanford Group, Inc., Richland, Washington.

RPP-ENV-39658, 2009, Hanford SX-Farm Leak Assessments Report, Rev. 0, CH2M HILL Plateau Remediation Company, Richland, Washington.

RPP-RPT-43704, 2011, Hanford BY-Farm Leak Assessments Report, Rev. 0, Washington River Protection Solutions, LLC., Richland, Washington.

RPP-RPT-47337, 2011, Specifications for the Mineralization of the Stress Corrosion Cracking Threat in Double-Shell Tank Wastes, Rev. 0, Washington River Protection Solutions, LLC., Richland, Washington.

RPP-RPT-50097, 2011, Hanford 241-U Farm Leak Inventory Assessment Report, Rev. 0, Washington River Protection Solutions, LLC., Richland, Washington.

RPP-RPT-54909, TBD, Hanford Single-Shell Tank Leak Causes and Locations - Summary, Washington River Protection Solutions, LLC., Richland, Washington.

SD-WM-TI-302, 1987, Hanford Waste Tank Sluicing History, Rev. 0, Westinghouse Hanford Company, Richland, Washington.

SD-WM-TI-356, 1988, Waste Storage Tank Status and Leak Detection Criteria, Rev. 0, Westinghouse Hanford Company, Richland, Washington.

TFC-ENG-CHEM-D-42, 2009, Tank Leak Assessment Process, Rev. B-2, CH2M HILL Hanford Group, Inc., Richland, Washington.

WHC-EP-0449, 1991, The Sort on Radioactive Waste Type Model: A Method to Sort SingleShell Tanks into Characteristic Groups, Westinghouse Hanford Company, Richland, Washington.

WHC-EP-0772, 1994, Characterization of the Corrosion Behavior of the Carbon Steel Liner in Hanford Site Single Shell Tanks, Westinghouse Hanford Company, Richland, Washington.

WHC-MR-0132, 1990, A History of the 200 Area Tank Farms, Westinghouse Hanford Company, Richland, Washington.

WHC-SD-WM-ER-325, 1994, Historical Tank Content Estimate for the South West Quadrant of the Hanford 200 East Area, Rev. 0, ICF Kaiser Hanford Company, Richland, Washington.

WHC-SD-WM-TI-591, 1994, Maximum Surface Level and Temperature Histories for Hanford Waste Tanks, Rev. 0, Westinghouse Hanford Company, Richland, Washington. 
RPP-RPT-54915, Rev. 0

WHC-SD-WM-TI-665, 2003, Soil Load above Hanford Waste Storage Tanks, Rev. 0C, CH2M Hill Hanford Group, Inc., Richland, Washington.

WSRC-TR-90-512, 1990, Effect of Temperature on the Nitrite Requirement to Inhibit Washed Sludge, Westinghouse Savannah River Company, Aiken, South Carolina. 
RPP-RPT-54915, Rev. 0

Appendix A

Meeting Minutes

June 25, 2013

August 6, 2013

September 10, 2013 
From: $\quad$ D. G. Harlow

Phone: $\quad 373-5514$

Location: Ecology Office

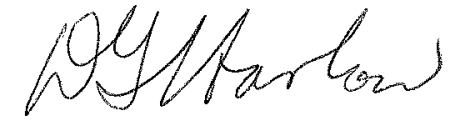

Date: June 25, 2013

Subject: $\quad$ Tank Farm Leak Integrity Assessments

To: Distribution/Attendees

Attendees:

Jim Alzheimer, ECOLOGY

Don Harlow, WRPS

Jim Field, WRPS

Jeremy Johnson, ORP

Les Fort, WRPS

Crystal Girardot, WRPS

Ted Venetz, WRPS

\section{PURPOSE:}

The purpose of this meeting was to review and discuss aspects of the Tank U-104 Leak Causes and Locations draft report; as well as undertake a final review of the May 29, 2013 Meeting Summary on tank C-105.

\section{Tank U-104 Leak Causes and Locations Status}

The results from the tank U-104 analysis were discussed. It was concluded that the tank U-104 liner failed as a result of a liner bulge at the bottom of the tank detected in July 1956. The measured 5- $\mathrm{ft}$ bulge in the liner was discovered at the end of a sluicing campaign following the tank being refilled with metal waste (MW). Designated leak test water was added to tank U-104 in 1957 and pumped out in 1961 with a determined release of approximately $48 \mathrm{kgal}$. Discussed was the plausible mechanism for the tank liner to bulge to the extent measured may be the result of vaporization of moisture under the liner. How the moisture at the suspected time of bulging got under the liner, became trapped, vaporized, and overcame the hydrostatic pressure when the tank was emptied is unknown. No liner bulge was reported after the first MW sluicing of the tank.

The drywells around tank U-104 were installed in the 1974-1976 timeframe, approximately 18 years after the bulge was discovered. The first loggings of drywells 60-04-08, 60-04-10, 60-0701, and 60-07-11 measured radioactivity. Two additional direct pushes (C5597 and C5601) were made in 2007.

Drywells 60-04-08, 60-04-10, 60-07-01, 60-07-11, and direct push C5601 all indicate radioactivity that could be the result of a tank leak. Radioactivity was detected 50 to 55 -ft below grade surface (BGS) which is 12 to 17-ft below the base of the tank. Direct push C5597, located $35.6-\mathrm{ft}$ to the northeast of tank U-104 next to the cascade line, detected a peak at $\sim 24-\mathrm{ft}$ BGS indicating a near surface release such as a pipeline leak. However, the source remains unknown and a tank liner leak cannot be ruled out. 


\section{RPP-RPT-54915, Rev. 0}

It was concluded that the bottom liner bulge was likely the result of waste thermal conditions. There appears to be little contribution from tank design, construction temperatures, and/or waste chemistry. Drywell readings indicate waste was released southeast of tank U-104 at or near the tank footing.

\section{Tank C-105 Meeting Summary - May 29, 2013}

The tank C-105 meeting summary with attached comments from the Tank C-105 Leak Causes and Locations segment including comment resolutions was handed out for review and approval.

\section{ACTIONS:}

1. All: Review the May 29, 2013 meeting summary from tank C-105 and provide comments by July 18, 2013.

Status: Complete.

2. All: Provide comments for the Tank U-104 Leak Causes and Locations report by July 18, 2013.

Status: Complete. No comments were received.

\section{NEXT MEETING:}

Review Tank U-110 Leak Location and Cause report.

Date: $\quad$ Tuesday August 6, 2013

Time: $\quad 2: 30 \mathrm{pm}$

Location: Ecology Room 3B 


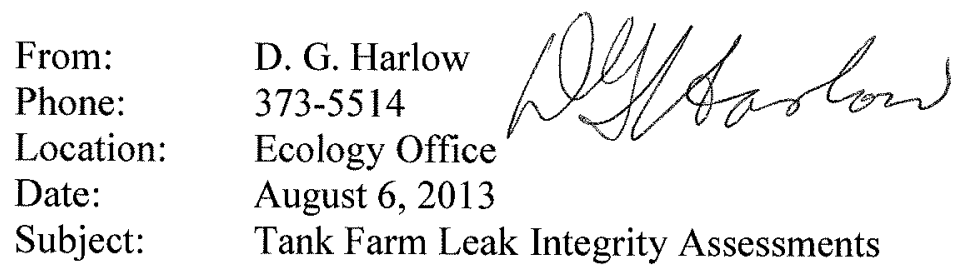

To: $\quad$ Distribution/Attendees

Attendees:
Jim Alzheimer, ECOLOGY
Don Harlow, WRPS
Joe Caggiano, ECOLOGY
Jeremy Johnson, ORP

Crystal Girardot, WRPS

\section{PURPOSE:}

The purpose of this meeting was to review and discuss aspects of the Tank U-110 Leak Causes and Locations draft report; as well as undertake a final review of the June 25, 2013 Meeting Summary on tank U-104.

\section{Tank U-110 Leak Causes and Locations Status}

The results from the tank U-110 analysis were discussed. It was concluded that the tank U-110 liner failed probably as a result of chemistry corrosion from storage of REDOX concentrated salt waste and/or laboratory waste (chemical composition unknown). Tank U-110 was first suspected of leaking based on a 0.5 -in liquid level decrease that was reported between May 24, 1975 and June 26, 1975. No temperature data was recovered for tank U-110 from May 1946 when the tank was first put into service until 1974, except for a one year period from August 1956 to August 1957. Temperatures during REDOX waste storage were high enough to cause evaporation from June 1954 to August 1955; however, there were no indications of self-boiling in the reports recovered. Temperatures of $\mathrm{CW}$ transferred to the tank after pumping REDOX waste were reported to be $\sim 140^{\circ} \mathrm{F}$ in August 1956 and declined to $\sim 115^{\circ} \mathrm{F}$ by August 1957 .

The drywells around tank U-110 were installed in the 1973-1976 timeframe, shortly after the tank was suspected of leaking. The only drywell that measured radioactivity was drywell 60-1007 (drilled in 1974) which reported an initial peak at 33-ft BGS and subsequent peak at $\sim 54-\mathrm{ft}$ BGS. One additional direct push (C5607) was made in 2007 (adjacent to drywell 60-10-07) which confirmed a radioactivity peak at $\sim 52-\mathrm{ft}$ BGS.

It was suggested in the meeting to add in the decay curves from document RPP-7729 for drywell 60-10-07 to the report or indicate the radionuclides in the text.

It was concluded that the tank U-110 liner leaked in the south southwest portion of the tank at or near the tank base possibly as a result of chemistry corrosion. There appears to be little contribution from tank design and/or construction temperatures. 
RPP-RPT-54915, Rev. 0

Tank U-104 Meeting Summary - June 25, 2013

The tank U-104 meeting summary was handed out for review and approval.

\section{ACTIONS:}

3. All: Review the June 25, 2013 meeting summary from tank U-104 and provide comments by August 20, 2013.

Status: In Progress.

4. All: Provide comments for the Tank U-110 Leak Causes and Locations report by August 20, 2013.

Status: In Progress.

NEXT MEETING:

Review Tank U-112 Leak Location and Cause report.

Date: $\quad$ Tuesday September 10, 2013

Time: $\quad 2: 30 \mathrm{pm}$

Location: Ecology Room 3B 


\section{MEETING SUMMARY}

From:

Phone:

Location:

Date:

Subject:

To:
D. G. Harlow

373-5514

Ecology Office

September 10, 2013

Tank Farm Leak Integrity Assessments

Distribution

Jim Alzheimer, ECOLOGY

Mike Barnes, ECOLOGY*

Joe Caggiano, ECOLOGY*

Crystal Girardot, WRPS*

Don Harlow, WRPS*

Jeremy Johnson, ORP

Ted Venetz, WRPS

Dennis Washenfelder, WRPS

*Attendees

\section{PURPOSE:}

The purpose of this meeting was to review and discuss aspects of the Tank U-112 Leak Causes and Locations draft report, approve the August 6, 2013 Meeting Summary on tank U-110, and distribute the complete U Farm Leak Causes and Locations draft report.

\section{Tank U-112 Leak Causes and Locations Status}

The results from the tank U-112 analysis were discussed. It was concluded that the tank U-112 liner failed probably as a result of chemistry corrosion from storage of REDOX concentrated salt waste (for a total of about 16 years) possibly coupled with bottom liner deformation (indicated in photographs of the waste surface taken March 1970). Tank U-112 was first suspected of leaking based on a 3-in liquid level decrease that was reported between February 1969 and March 1970 (RHO-CD-896). However, the leak may have started as early as December 1964 due to a declining liquid level and no transfers occurring during this time. No temperature data was recovered for tank U-112 from October 1947 when the tank was first put into service until 1976, except for a one year period from July 1956 to July 1957. Temperatures during this one year period were between 60 and $70^{\circ} \mathrm{F}$ which was two months after a reported $21 \mathrm{kgal}$ of CW was added to $514 \mathrm{kgal}$ of REDOX concentrated salt waste. Temperatures were likely less in tank U112 as indicated compared to tank $U-110$ or $U-111$ as tank $U-112$ was the last tank in the cascade series.

The drywells around tank U-112 were installed in 1944 (drywell 60-00-08) and from 1970-1974, shortly after the tank was suspected of leaking. The only drywell that measured radioactivity was drywell 60-12-01 (drilled in 1974) which reported an initial peak at 50-ft BGS. One 


\section{RPP-RPT-54915, Rev. 0}

additional direct push (C5605) was made in 2007 (located between drywells 60-12-01 and 6012-03) which indicated moisture but only background levels of radioactivity.

It was suggested in the meeting that additional direct pushes are being performed in U Farm this fiscal year and possibly next fiscal year for U Farm and TX Farm and to add in any relevant results to the leak causes and locations reports as appropriate.

It was concluded that the tank U-112 liner leaked in at least one location in the north northeast portion of the tank at or near the tank base possibly as a result of chemistry corrosion. There appears to be little contribution from tank design and/or construction temperatures.

It was also suggested in the meeting to add in any available information on the contractor used during the construction of $\mathrm{B}, \mathrm{C}, \mathrm{T}$, and $\mathrm{U}$ Farms and whether the same contractor was used for these tank farms or if multiple contractors were used. No records have been recovered indicating the quality control during construction of these earlier tank farms.

A revision to Figure 2-1 in the report was suggested to include tank U-101 as an assumed leaker which is identified in the Waste Status Summary monthly reports (HNF-EP-0182). Tank U-101 was subsequently designated to be assessed by the procedure TFC-ENG-CHEM-D-42 in RPPRPT-50097 and therefore will not be analyzed for the leak causes and locations report. It was also recommended to add all of the 2007 direct pushes to this figure.

A comment was made during the meeting about whether sampling was done in the direct push (C5605) when it was installed in 2007. The report addresses this in Section 6.5.1.7 which identified moisture and spectral gamma logging performed in this direct push. Results identified elevated moisture contents but only background levels of Cs-137 were recorded. Relevant direct push results are included in the other two leaking U Farm tanks.

\section{Tank U-110 Meeting Summary - August 6, 2013}

The previously reviewed tank U-110 meeting summary was approved.

\section{ACTIONS:}

5. All: Review the September 10, 2013 meeting summary from tank U-112 and provide comments by September 24, 2013.

Status: Completed. Received editorial comments from Joe Caggiano and the meeting summary was updated.

6. All: Provide comments for the entire U Farm Leak Causes and Locations draft report by September 24, 2013.

Status: Completed. See Attachment 1.

\section{NEXT MEETING:}

Review Tank T-106 Leak Location and Cause report.

Date: $\quad$ TBD

Time: $\quad$ TBD

Location: TBD 


\section{REVIEW COMMENTS with RESPONSES \\ J. A. Caggiano September 12, 2013 \\ U FARM DRAFT REPORT COMMENTS}

\section{GENERAL:}

1. There is a great deal of redundancy in this and other reports. The same information seems to be cut and pasted into several different sections. I would suggest you try to streamline the reports to reduce repetition. It gets tedious reading the same lines over and over. Some readers might get offended at this.

Response: Sections 1 and 2 of the document were designed to present background information on the tank farm in the document. Section 3 deals with common design features and construction details relevant to waste storage. Basic in-tank and ex-tank background is also presented in this section to be applied to individual leaking tanks that could affect causes for liner leaks and identification of possible liner leak locations. The last two subsections indicate how the previous information is used to address leak locations and causes. The next section(s) develop in-tank and ex-tank specific information for individual leaking tank(s). The individual leaking tank sections contain some consolidated information from sections 1 through 3 to be as close to stand alone as possible. This includes presenting relevant information as scenarios are developed through summaries of a leak cause and a leak location to a final conclusion. This results in repeating some information as the discussion progresses. This should help the reader who may want information on only one specific tank or a specific subsection to understand some of the background without referring to background section unless further information is needed.

2. Push holes are NOT drywells. They are generally constructed in pairs; the first hole is used for logging moisture and gross gamma to select intervals for sampling in the second hole that is generally pushed very nearby. These are one time logs and samples with no potential for later logging or sampling, as these holes are decommissioned shortly after their one-time use is completed. Drywells remain open (but capped and locked) so as to remain accessible for logging as conditions require. Most drywells were logged multiple times.

Response: Deleted the word "drywell" as it relates to direct pushes.

\section{SPECIFIC COMMENTS:}

1. Pg. i, para 4. First sentence should be amended to indicate radial "transport in the soil."

Response: Inserted "transport in the soil" after the word "radial".

2. Pg. i, para 4. Last sentence should be amended to include "or to point of egress near the tank bottom." Slow leaks from a cascade or spare inlet line might "dribble" down the 
tank wall and then flow laterally once they hit the footing. But high levels of Cs-137 at tank bottom likely indicate a leak at that location.

Response: Agree, indications point to egress of the waste near the bottom of the tank. The depth of detected radioactivity between 50-ft and 54-ft BGS, more than 10-ft below the bottom of the tank base, seemed to point that way. Details pertaining to the individual tanks are in the individual tank sections and indicate liner leaks could follow different paths to the point of egress to the soil. Also where there are indications of overfilling above the cascade or inlet lines such as tank U-112 the possibility of leakage form those sites are addressed.

3. Pg. 2-2. This figure needs to be either re-titled, or amended to include the C-200 series tanks. You may want to designate U-101 as an "assumed leaker" from the Hanlon reports which the leak assessment team did not believe.

Response: Retitled the figure, included tank U-101 as an assumed leaker, and modified the footnote pertaining to tank U-101to indicated it was not included in the document and why. The 200 series tanks have not been included as they are not in the scope of the milestone.

4. Pg. 3-6, last para in 3.1.2. As suggested in the meeting, you may want to check to see if different contractors were involved in tank farm construction and whether they might have had different quality control standards regarding welding steel plates.

Response: The same contractor (Morrison-Bechtel-McCone) built all 64 B, C, T, U Tanks (HAN-10970, Volume 1, page 271). This and other tank contractors will be addressed in either the summary document or in the Common Factors document.

5. Pg. 3-8, Sect. 3.2.3. Bulging is listed as a cause for tank failure, but bulging is an effect because of some unidentified cause on which one can speculate. I would also add that any buckling that remains in the elastic realm would not produce a permanent bulge, but could weaken the steel and facilitate SCC or some other form of corrosion.

Response: Added the statement that a bulge is typically caused by rapid vaporization of moisture under the liner and that stressing the liner may not produce a permanent bulge. Susceptibility to corrosion was already mentioned in the paragraph.

6. Pg. 3-9, para 1 discusses operating specification to prevent SCC which were developed in 1983, well after all the SSTs were out of service. Provides guidance in hindsight, but is "too little, too late" for SSTs.

Response: Agree. The paragraph indicates many investigations led to the 1983 specification. The individual tank sections compare available historical corrosion chemistry data to later specification as a means to identify possible liner failure causes.

7. Pg. 3-10, last para Sect. 3.2.4. Sentence reads, "Therefore, waste chemistry conditions are speculative when sample and temperature data..." Consider speculating and what might be done further to investigate these speculations. 
Response: Revised the last paragraph of section 3.2.4 to address the speculation comment.

8. Pg. 3-11, Drywells. First you say that the earliest drywells were constructed in 19701976 , and in the following paragraph talk about the "00" series of drywells constructed shortly after tank farm construction. Correct these inconsistencies.

Response: Section 3.3.2, second sentence; added the words "tank specific" after the word "earliest", now reads, "The earliest tank specific drywells were installed ....." Tank Farm drywells " 00 " series are addressed later in the paragraphs.

9. Pg. 4-5, last para. What was the LL decline for the "leak test water" added to this tank in 1957 and that remained for almost 4 years?

Response: April 1957 to March 23, 1961, see Section 4.4.1 for the details on the leak test water liquid level decrease of $50 \mathrm{k}$ gal over $\sim 4$ years.

10. Pg. 4-7. The figure should be called "U-104 Operating History". Titled "Leak History", it suggests that every entry should describe a release. Check other similar figures as well.

Response: The title of Figure 4-2 is "Operational Leak History of Tank U-104" and was intended to gather both Operational and Leak information in one timeline with emphasis placed in red on the more important entries. Figures 5.2 and 6.2 have the same wording for tanks U-110 and U-112.

11. Pg. 4-9, last para. Could the periodic "leveling out" of LL be due to lower evaporation rates during the colder winter months? Just a question for consideration.

Response: There may be a seasonal effect but reviewing the actual data used for the Figure 4-4 plot indicates inconsistent seasonal effects. This could be some kind of a data problem but the observation was included to indicate apparent uncertainty with the liquid level decrease for such a long period of observation with no pumping action.

12. Pg. 5-5, para 2. If $39 \mathrm{kgal}$ of water were added to this tank at a time when tank storage space was scarce, there had to be a reason and I would guess that it was to lower temperature from those considered too high for tank stability or at least beyond operating specifications. If so, temperature conditions are even further supported. Do you know why cooling water was added?

Response: A flex jumper was found leaking in the 204-S diversion box and the water was transferred (HW-56972 Page D-2) and HW-57122 page 4 indicates the $39 \mathrm{k}$ gal of water was from 204-S. There probably was a temperature reduction in tank U-110 but it appears that the primary reason for the transfer was to remove the water from 204-S. The temperature towards the middle of 1957 was $\sim 115^{\circ} \mathrm{F}$ which was about a year before the water transfer.

13. Pg. 6-5, para 5. $549 \mathrm{kgal}$ would be about $19 \mathrm{kgal}$ above the listed capacity for this tank and definitely an overfill which is supported by the "beach line" in Fig. 6-5. That raises the question of how reliable earlier LL were, given that this "new level" was found after replacing an electrode. 
Response: Agree. The liquid level measurement reliability especially in the earlier years is a large subject to tackle and may not change the basic conclusions of the causes and locations of a tank liner leak. Reliability of liquid level as it relates to identifying tank leak causes and locations has been handled on a tank by tank basis by dropping suspect data, trending, identifying second sources, identifying collaborating information, and others. We plan on addressing this subject in the summary document.

14. Pg. 6-11, para 2 speaks of adding $21 \mathrm{kgal}$ of $\mathrm{CW}$ which would be an overfill and probably to cool waste that was considered too hot and out of spec. Should any of this be mentioned?

Response: Figure 6-4 shows the liquid level above the cascade inlet with the liquid level decreasing. However, the liquid level continued to decrease after reaching the cascade inlet which indicated a leak. Section 6.4.2 indicated that the U-110 liquid level slowly decreased (probably as a result of the waste temperature and evaporation). However, the third tank in the cascade, tank U-112 did not experience a decreasing liquid level e.g. lower temperature and less or no evaporation. How much of a temperature effect the 21 $\mathrm{kgal}$ of $\mathrm{CW}$ had on the $514 \mathrm{kgal}$ of cascaded REDOX waste in tank U-112 is speculative without detailed temperature data, however, two months after receiving the $21 \mathrm{kgal}$ of $\mathrm{CW}$, sludge temperatures range between $70^{\circ} \mathrm{F}$ and $60^{\circ} \mathrm{F}$. Therefore, the temperature of the REDOX waste in tank U-112 must have been relatively low at least compared to tank $\mathrm{U}-110$. Therefore, a projected average temperature was indicated as near $100^{\circ} \mathrm{F}$ (see Sections 6.4.1 and 6.4.2).

15. Pg. 6-13. In discussing the "replacement of tank bottom liners", an April 1944 report is cited. As construction began in February, how far along could construction have been? Something seems amiss here.

Response: Construction of U Farm began in February 1944; however, the replacement of the bottom liners discussed in the April 1944 report is referring to the construction of T Farm. A photo was taken on January 19, 1944 of T Farm construction (P1147, N1545817) that indicates construction of the tank pads started earlier as some steel was laid out for a part of one tank. Photo P1955 N 1557899 taken March 23, 1944 shows the T Farm construction of the tanks with the knuckles in place. Photo P6507 N 1603404 taken September 2, 1944 shows the farm in the process of backfill. Photo P4709 N 1591787 taken September 19, 1944 shows the final backfilling of the farm. The time line is $\mathrm{OK}$. 